



\section{USER GUIDE FOR PROCUREMENT OF PLANT DESIGN, SUPPLY, AND INSTALLATION STANDARD BIDDING DOCUMENT}

DECEMBER 2021

For projects governed by Procurement Regulations for ADB Borrowers:

Goods, Works, Nonconsulting and Consulting Services (2017) 


\section{(C) $\$ @$ Creative Commons Attribution-NonCommercial-NoDerivs 3.0 IGO license BY NC ND (CC BY-NC-ND 3.0 IGO)}

(C) 2021 Asian Development Bank 6 ADB Avenue, Mandaluyong City, 1550 Metro Manila, Philippines

Tel +632 8632 4444; Fax +63286362444

www.adb.org

Some rights reserved. Published in 2021.

ISBN 978-92-9269-300-8 (print); 978-92-9269-301-5 (electronic)

Publication Stock No. TIM210535-2

DOI: http://dx.doi.org/10.22617/TIM210535-2

The views expressed in this publication are those of the authors and do not necessarily reflect the views and policies of the Asian Development Bank (ADB) or its Board of Governors or the governments they represent.

ADB does not guarantee the accuracy of the data included in this publication and accepts no responsibility for any consequence of their use. The mention of specific companies or products of manufacturers does not imply that they are endorsed or recommended by ADB in preference to others of a similar nature that are not mentioned.

By making any designation of or reference to a particular territory or geographic area, or by using the term "country" in this document, $A D B$ does not intend to make any judgments as to the legal or other status of any territory or area.

This work is available under the Creative Commons Attribution-NonCommercial-NoDerivs 3.0 IGO license (CC BY-NC-ND 3.0 IGO) http://creativecommons.org/licenses/by-nc-nd/3.0/igo/. By using the content of this publication, you agree to be bound by the terms of this license. For attribution and permissions, please read the provisions and terms of use at https://www.adb.org/terms-use\#openaccess.

This CC license does not apply to non-ADB copyright materials in this publication. If the material is attributed to another source, please contact the copyright owner or publisher of that source for permission to reproduce it. $\mathrm{ADB}$ cannot be held liable for any claims that arise as a result of your use of the material.

Please contact pubsmarketing@adb.org if you have questions or comments with respect to content, or if you wish to obtain copyright permission for your intended use that does not fall within these terms, or for permission to use the ADB logo.

Corrigenda to ADB publications may be found at http://www.adb.org/publications/corrigenda.

Notes:

In this document, "\$" referes to United States dollars.

This document applies to projects governed by the Procurement Regulations for ADB Borrowers:

Goods, Works, Nonconsulting and Consulting Services (2017, as amended from time to time). 


\section{Contents}

Abbreviations

\section{SBD Plant: Single-Stage Bidding Procedure}

Documents Structure Flowchart.

Section 1: Instructions to Bidders (ITB) ...

This section specifies the procedures to be followed by Bidders in the preparation and submission of their Bids.

Information is also provided on the submission, opening, and evaluation of bids and on the award of contract.

Section 2: $\quad$ Bid Data Sheet (BDS)

This section consists of provisions that are specific to each procurement and supplement the information or requirements included in Section 1 (Instructions to Bidders).

Section 3: Evaluation and Qualification Criteria (EQC)...

This section contains the bid evaluation criteria to determine the lowest evaluated bid and lists the necessary qualifications of Bidders.

Section 4: $\quad$ Bidding Forms (BDF).

This section contains the forms to be completed by the Bidder and submitted as part of its Bid.

Section 5: $\quad$ Eligible Countries (ELC)

This section contains the list of eligible countries.

Section 6: Employer's Requirements (ERQ)

This section contains the Scope of Supply of Plant and Services, Specifications, the Drawings, and

Supplementary Information that describe the Facilities to be procured, Personnel Requirements, Equipment

Requirements, Certificates, and Change Orders.

Section 7: General Conditions of Contract (GCC).

This section contains the general clauses to be applied on all contracts. These Conditions are subject to the variations and additions set out in Section 8 (Special Conditions of Contract).

Section 8: Special Conditions of Contract (SCC).

This section contains provisions that are specific to each contract and that modify or supplement the General

Conditions of Contract. Whenever there is a conflict, the provisions herein shall prevail over those in the

General Conditions of Contract.

Section 9: Contract Forms (COF).

This section contains forms that, once completed, will form part of the Contract. The forms for Performance Security and Advance Payment Security, when required, shall only be completed by the successful Bidder after contract award. 


\section{SBD Plant: Two-Stage Bidding Procedure}

Documents Structure Flowchart.

Section 1: Instructions to Bidders (ITB)

This section specifies the procedures to be followed by Bidders in the preparation and submission of their Bids.

Information is also provided on the submission, opening, and evaluation of bids and on the award of contract.

\section{Section 2: $\quad$ Bid Data Sheet (BDS)}

This section consists of provisions that are specific to each procurement and supplement the information or requirements included in Section 1 (Instructions to Bidders).

\section{Section 3: Evaluation and Qualification Criteria (EQC)}

This section contains the bid evaluation criteria to determine the lowest evaluated bid and lists the necessary qualifications of Bidders.

\section{Section 4: $\quad$ Bidding Forms (BDF)}

This section contains the forms to be completed by the Bidder and submitted as part of its Bid. 


\title{
Abbreviations
}

\author{
ADB......................Asian Development Bank \\ BDF ....................... bidding forms \\ BDS ...................... bid data sheet \\ COF.............................. \\ CON .....................historical contract nonperformance \\ ELC ......................eligible countries \\ ELI .........................eligibility form \\ ENAA ................... Engineering Advancement Association of Japan \\ EQC ........................evaluation and qualification criteria \\ ERQ ......................employer's requirements \\ EXP .......................experience form \\ FIN........................financial data form \\ GCC ......................general conditions of contract \\ IFB..........................invitation for bids \\ ITB ........................instructions to bidders \\ OCB .....................open competitive bidding \\ SBD .......................standard bidding document \\ SCC .......................special conditions of contract
}





\section{Introduction}

The purpose of this user's guide is to guide Borrowers on how to prepare a bidding document based on the Standard Bidding Documents of the Asian Development Bank (ADB) for the Procurement of Plant Design, Supply, and Installation (SBD Plant).

This user's guide covers two SBD Plant documents: SBD Plant - Single-Stage Bidding Procedure and SBD Plant - Two-Stage Bidding Procedure.

\section{SBD Plant Using a Single-Stage Bidding Procedure}

In the single-stage bidding procedure, Bidders submit bids in one envelope containing both the price proposal and the technical proposal. The envelopes are opened in public at the date and time advised in the Bidding Document. The bids are evaluated, and following approval by ADB, the contract is awarded to the Bidder whose bid has been determined to be the lowest evaluated substantially responsive bid.

\section{SBD Plant Using a Two-Stage Bidding Procedure}

In the two-stage bidding procedure, Bidders first submit their technical proposals, in accordance with the specifications, but without prices. The technical proposals are opened at the date and time advised in the Bidding Document. The technical proposals are evaluated and may be discussed with the Bidders. Deficiencies, extraneous provisions, and unsatisfactory technical features are pointed out to the Bidders, whose comments are carefully evaluated. The Bidders are allowed to revise or adjust their technical proposals to meet the requirements of the Employer. The objective of this process is to ensure that all technical proposals conform to the same acceptable technical standards and meet the technical solution required by the Employer. Bids of Bidders who are unable or unwilling to bring their bids to the acceptable technical standards may be rejected as deficient bids. After the evaluation of technical proposals has been approved by $A D B$, the second stage is to invite Bidders to submit price proposals and revised technical proposals in compliance with the acceptable technical standards. The revised technical proposals and price proposals are opened in public at a date and time advised by the Employer. In setting the date, the Employer should allow sufficient time for Bidders to incorporate the changes involved in the technical proposals and to prepare price proposals. The price proposals and revised technical proposals are evaluated, and following ADB's approval, the contract is awarded to the Bidder whose bid has been determined to be the lowest evaluated substantially responsive bid.

The SBD Plant documents are available only in electronic format. An important feature of the documents is that they can be used with minimum changes, as they do not contain explanatory comments that are not part of the Bidding Document.

The SBD Plant documents must be used for the procurement of plant, financed in whole or in part by ADB, unless ADB agrees to the use of other bidding documents that are acceptable to ADB.

The SBD Plant documents are intended to be used for the procurement of plant through international competitive bidding when

- the contract involves the design, supply, installation, and commissioning of specially engineered plant and equipment such as turbines, generators, boilers, electrical switchyards or substations, 
pumping stations, telecommunication systems, process and wastewater treatment plants, and similar projects;

- the value of the plant and equipment represents the major part of the estimated contract value; and

- the nature and complexity of the plant and equipment is such that the facilities cannot safely be taken over by the Employer without comprehensive testing, pre-commissioning, commissioning, and acceptance procedures being followed.

The SBD Plant documents anticipate that the contractor is responsible for each activity required to complete the facilities, e.g., design, manufacture, delivery, installation, testing, commissioning, training, and required civil works portions. However, these conditions may be adapted for single-responsibility contracts where some activities, such as parts of the preliminary design or site preparation works, are done by others.

The procedures and practices incorporated in the SBD Plant documents have been developed through broad international experience and are based on the Master Bidding Document for Procurement of Plant Design, Supply, and Installation, prepared by multilateral development banks and other public international financial institutions, and has the structure and the provisions of the Master Procurement Document, except where ADB-specific considerations have required a change.

The General Conditions of Contract are based on the Model Form of International Contract for Process Plant Construction published by the Engineering Advancement Association of Japan (ENAA) as used in the Standard Bidding Document for Supply and Installation of Plant and Equipment of the World Bank. The multilateral development banks participating in the procurement harmonization process gratefully acknowledge the contribution of ENAA to the advancement of good contracting practices by its borrowers.

The role of "the Engineer," as found in the SBD for Works is not included in these SBDs. In its place, and fulfilling similar duties, are two parties: the "Project Manager" and the "Dispute Board."

The Project Manager is appointed by the Employer to supervise and manage the contract on behalf of the Employer, to achieve the Employer's objectives of completing the contract. When appointing the project manager, the Employer may either select a reputable firm of consulting engineers experienced in the particular field, or appoint one of its staff as project manager, if ADB is satisfied that the Employer has suitable in-house expertise.

The documents foresee the nomination of a Dispute Board whose role is to review and decide upon matters of potential dispute between the parties where the parties, with or without the help of the project manager, have been unable to settle a matter amicably. The costs of the Dispute Board are shared equally by both parties. Arbitration is resorted to only if the parties fail to settle the dispute through the Dispute Board.

This guide includes preliminary sections on the Bidding Process and the Invitation for Bids.

ADB welcomes any feedback or experiences from both borrowers and Bidders on the use of its SBD Plant Design, Supply, and Installation documents. For information on procurement under ADB-financed projects, contact

Procurement, Portfolio and Financial Management Department (PPFD)

Asian Development Bank

6 ADB Avenue, Mandaluyong City

1550 Metro Manila, Philippines

E-mail: procurement@adb.org

Tel: +63286324444

Fax: +63286362444 [Attn: Director General, PPFD]

www.adb.org 


\section{The Bidding Process}

The open competitive bidding (OCB) process includes six main phases: (i) advertisement and notification, (ii) preparing and issuing the Bidding Document, (iii) bid preparation and submission, (iv) bid opening, (v) bid evaluation, and (vi) contract award.

\section{Advertisement and Notification}

An Invitation for Bids (IFB) shall be advertised on the ADB website; on a freely and publicly accessible website in English; and in a newspaper of national circulation (at least in one English language newspaper, if available) or website in the borrower's country. A copy of the IFB shall be submitted to ADB for no-objection and for publication on the ADB website in accordance with the Procurement Regulations for ADB Borrowers: Goods, Works, Nonconsulting and Consulting Services (2017, as amended from time to time).

For large or specialized contracts, ADB may additionally require that the IFB be advertised in well-known technical magazines or trade publications, or in newspapers of wide international circulation, with sufficient time to enable prospective Bidders to prepare and submit Bids.

\section{Preparing and Issuing a Bidding Document}

The Employer is responsible for preparing and issuing the Bidding Document for a specific contract.

The Bidding Document shall be prepared by the Employer based on the appropriate SBD issued by ADB, as this is a mandatory requirement for contracts to be financed by ADB.

The Employer shall prepare the Bidding Document using the published version of the SBD without suppressing or adding text to the sections of the document that must be used without modification, which are Section 1 (Instructions to Bidders) and Section 7 (General Conditions of Contract). All information and data particular to each individual bidding process must be provided by the Employer in the following sections of the Bidding Document:

- Section 2 (Bid Data Sheet)

- Section 3 (Evaluation and Qualification Criteria)

- Section 4 (Bidding Forms)

- Section 5 (Eligible Countries)

- Section 6 (Employer's Requirements)

- Section 8 (Special Conditions of Contract)

- Section 9 (Contract Forms)

The following directions should be observed by the Employer when finalizing the Bidding Document:

- In preparing the Bidding Document, the Employer should refer to this User Guide for Procurement of Plant Design, Supply, and Installation as it contains guidance and instructions for the Employer. 
- Specific details, such as name of the Employer, address for bid submissions, qualification requirements, electronic procurement procedures, etc. should be provided in the spaces indicated by italicized notes in brackets.

- The italicized notes, giving guidance and instructions for the Employer, except those that apply to forms to be filled out by Bidders, should be deleted from the actual Bidding Document.

- Where alternative clauses or text are shown, the Employer shall select the most appropriate for the particular plant or contract and discard the unused alternative clauses or text.

The Employer shall allow Bidders sufficient time (generally, not less than 6 weeks from the issuance or publication date of the Invitation for Bids or the date of availability of Bidding Document, whichever is later), to study the Bidding Document, prepare complete and responsive Bids, and submit their Bids.

\section{Bid Preparation and Submission}

The Bidder is solely responsible for the preparation and submission of its Bid. During this stage, the Employer shall

- promptly respond to requests for clarifications from Bidders and amend the Bidding Document as needed; and

- amend the Bidding Document only with prior approval of ADB.

\section{Bid Opening}

The Employer is responsible for the Bid Opening, which is a critical event in the bidding process. The Employer shall appoint experienced staff to conduct the Bid Opening, as inappropriate procedures at Bid Opening are usually irreversible and may lead to cancellation of the bidding process with consequent delays and waste of resources.

The Employer, in observance of best practices, shall perform the following checks:

- Conduct the Bid Opening strictly following the procedures as specified in the Instructions to Bidders for all Bids received not later than the date and time of the bid submission deadline. The term "Bid Opening" should be understood in the context of the ITB because, as provided in the ITB, a Bid for which a Bid Withdrawal or Bid Substitution notice was received on time shall not be opened, but returned unopened to the Bidder. The sequence in which Bids are handled, opened, and recorded is crucial.

- Ensure that all Bids that were received on time are accounted for, before starting the Bid Opening, as Bids that are not opened and read out at Bid Opening shall not be considered further.

- Not reject any Bid at Bid Opening, except for late bids received after the date and time of the bid submission deadline. Technically, late bids should not reach the Bid Opening, but in certain cases a Bidder may attempt to submit its bid at the Bid Opening place after the deadline. This late bid shall also not be considered.

- Examine the Bids at Bid Opening in accordance with the provisions of the Instructions to Bidders. The Employer shall, however, verify at Bid Opening the validity of the documentation, such as Power of Attorney or other acceptable equivalent document as specified in the Instructions to Bidders. The validity of a bid modification, bid withdrawal, or bid substitution should be confirmed because a withdrawn or substituted bid shall not be opened, or read out and, therefore, shall not be considered by the Employer. A valid bid modification shall be opened, read out, and recorded to modify a bid that was received on time. 


\section{Bid Evaluation and Contract Award}

The Employer is responsible for bid evaluation and contract award. The Employer shall appoint experienced staff to conduct the evaluation of the Bids. Mistakes committed at bid evaluation may later prompt complaints from Bidders, requiring reevaluation of the Bids, with consequent delays and waste of resources.

The Employer, in observance of best practices, shall

- $\quad$ keep the bid evaluation process strictly confidential;

- reject attempts or pressures to distort the outcome of the evaluation, including fraud and corruption; and

- strictly apply only and all of the evaluation and qualification criteria specified in the Bidding Document.

\section{Use of Electronic Procurement System}

When an electronic procurement system is used, the applicable procedures of the bidding process such as (i) advertisement and notification; (ii) preparing and issuing the Bidding Document; (iii) bid preparation and submission; (iv) bid opening; ( $v$ ) bid evaluation; and (vi) contract award, including the means of communication between the Employer and Bidders, shall be specified in the relevant clauses of Section 2 (Bid Data Sheet). 


\section{Invitation for Bids}

The Invitation for Bids (IFB) provides information that enables potential Bidders to decide whether to participate. Apart from the essential items listed in the Standard Bidding Document, the IFB should also indicate any important bid evaluation criteria, such as the application of domestic preference in bid evaluation, and qualification criteria, if no prequalification took place, such as a requirement for a minimum level of experience in contracts of a similar size and nature for which the IFB is issued.

The IFB is not a part of the Bidding Document and therefore it shall not be included in the Bidding Document.

The IFB shall be advertised on the Asian Development Bank (ADB) website; on a freely and publicly accessible website in English; and in a newspaper of national circulation (at least in one English language newspaper, if available) or website in the borrower's country. A copy of the IFB shall be submitted to ADB for no-objection and for publication on the ADB website in accordance with the Procurement Regulations for ADB Borrowers: Goods, Works, Nonconsulting and Consulting Services (2017, as amended from time to time).

For large or specialized contracts, ADB may additionally require that the IFB be advertised in well-known technical magazines or trade publications, or in newspapers of wide international circulation, in sufficient time to enable prospective Bidders to prepare and submit Bids. 


\title{
Standard Format for Invitation for Bids
}

\author{
[Letterhead of the Employer]
}

\begin{abstract}
Date.
Loan/Grant No. and Title

Contract No. and Title

Deadline for Submission of Bids.

[insert closing date and time]
\end{abstract}

1. The [insert name of the borrower or recipient] has received ${ }^{1}$ financing from the Asian Development Bank (ADB) toward the cost of [insert name of the project]. Part of this financing will be used for payments under the contract ${ }^{2}$ named above. Bidding is open to Bidders from eligible source countries of ADB. ${ }^{3}$

2. The [insert name of the Employer] ("the Employer") invites sealed bids from eligible Bidders for the construction and completion of [insert description of plant and services to be procured] ("the Facilities").

3. Open competitive bidding will be conducted in accordance with ADB's [insert appropriate bidding procedure $]^{5}$ procedure and is open to all Bidders from eligible countries as described in the Bidding Document. ${ }^{6}$

4. Only eligible Bidders with the following key qualifications ${ }^{7}$ defined in the bidding document may participate in this bidding:

5. To obtain further information and inspect the Bidding Documents, Bidders should contact:

[insert Employer's office ${ }^{8}$

[insert name of the officer]

[insert postal address or street address, include zip code]

[insert telephone number including country code]

[insert e-mail address]

[insert fax number]

6. To purchase the Bidding Documents in English, eligible Bidders should:

- write to the address above requesting the Bidding Documents for [insert number and title of the contract], and

- pay a nonrefundable fee ${ }^{9}$ of [insert amount and currency] by [insert method of payment]. ${ }^{10}$

Substitute with "has applied for" if appropriate.

Substitute "contracts" where bids are called concurrently for multiple contracts. Add a new para. 2 and renumber paras. 2-7 as follows: "Bidders may bid for one or several contracts, as further defined in the Bidding Document. Bidders wishing to offer discounts in case they are awarded more than one contract will be allowed to do so provided those discounts are included in the Letter of Bid."

3 Add if applicable: "This contract will be jointly financed by .... . insert name of cofinancing agency.... The eligibility rules and procedures of ADB will govern the bidding process."

$4 \quad$ A brief description of the type(s) of plant and services should be provided, including quantities, location of project, and other information necessary to enable potential Bidders to decide whether to respond to the invitation.

5 Insert one of the bidding procedures adopted by ADB, which are "(a) Single-Stage: One-Envelope, (b) Single-Stage: Two-Envelope, (c) Two-Stage, and (d) Two-Stage: Two-Envelope." The choice of the Two-Stage bidding procedure shall be subject to ADB's advance approval on a case-to-case basis, depending on the complexity of the contract and the particular circumstances surrounding its procurement and implementation.

6 The list of eligible countries will be specified in Section 5 of the Bidding Document.

7 Insert an additional paragraph indicating key qualification criteria consistent with the bidding document to enable potential Bidders to decide whether to respond to the invitation.

$8 \quad$ The borrower and the Employer may be the same or different entities. The text of the Invitation for Bids and the texts of the other associated documents must indicate which agency will act as the Employer.

$9 \quad$ The fee chargeable should only cover reproduction and mailing costs.

10 For example, cashier's check, direct deposit to a specified account number, etc. 
7. Deliver your bid:

- to the address [insert address];

- on or before the deadline: [insert closing date and time consistent with the Bidding Document]; and

- together with a Bid Security/Bid-Securing Declaration as described in the Bidding Document.

Bids will be opened promptly after the deadline for bid submission in the presence of Bidders' representatives who choose to attend.

8. When comparing Bids, Domestic Preference will be applied as stipulated in the Bidding Document. ${ }^{11}$

11 Include para. 8 only if Domestic Preference has been expressly provided in the Procurement Plan and is included in the Bid Data Sheet. 


\title{
Standard Format for Invitation for Second-Stage Bids
}

\author{
[Letterhead of the Employer]
}

\begin{abstract}
Date.
Loan/Grant No. and Title.

Contract No. and Title

Deadline for Submission of Bids.

[insert closing date and time]
\end{abstract}

To: [insert name and address of the Bidder]

1. We hereby inform you that you are invited to submit a sealed Second-Stage Bid for the execution and completion of the cited Contract for which you submitted a first-stage bid on [insert date of submission of first-stage bid consistent with the Bidding Document], which was reviewed during the clarification meeting(s) held on [insert dates] and has been found technically responsive.

2. Your Second-Stage Bid should include an updated technical and commercial bid based on the attached amendment, if any, ${ }^{12}$ and on the modifications, if any, listed in the Annex to the Memorandum entitled "Changes Required Pursuant to First-Stage Evaluation" issued as a result of the clarification meeting(s). ${ }^{13}$

3. Second-Stage Bids shall be submitted on or before [insert time, date, and address for Second-Stage Bid submission] and will be opened in the presence of the Bidder's representatives who choose to attend at [insert time, date, and address for Second-Stage Bid opening]. ${ }^{14}$

4. Second-Stage Bids shall remain valid for [insert number of days consistent with the Bidding Document $]^{15}$ after the date of the bid opening prescribed above.

5. All Second-Stage Bids must be accompanied by a bid security/Bid-Securing Declaration as described in the Bidding Document.

6. [If Bidders were prequalified, include any requirement for updating information provided during prequalification. $]^{16}$

12 Amendment shall be common to all Bidders invited to submit a Second-Stage Bid.

13 A copy of the respective annex may be attached to the letter to the corresponding Bidder.

14 The dates of bid submission and bid opening should be the same, and the time should also be the same or immediately thereafter.

15 The period should be sufficient to permit completion of the Second-Stage Bid evaluation, review of the recommended selection by $A D B$, the process of obtaining approvals, and notification of award. A realistic period should be specified to avoid the need for bid validity extension.

16 Information to be updated may be specified such as an updated financial situation, new contractual commitments, or current litigation. 
7. Please confirm receipt of this letter immediately in writing by fax [insert fax number], or by e-mail [insert e-mail address]. If you do not intend to bid, we would appreciate being so notified again in writing at your earliest opportunity.

Yours truly,

Authorized signature:

Name and title:

Attachments: [insert title of amendments, if any, and the memorandum entitled "Changes Required Pursuant to First-Stage Evaluation"] 


\section{SBD Plant: \\ Single-Stage Bidding Procedure}

\section{Documents Structure Flowchart}

\begin{tabular}{|l|l|l|}
\hline \multicolumn{1}{|c|}{ Bidding Document } & \multicolumn{1}{|c|}{ Issued by Employer } \\
\cline { 2 - 3 } & $\begin{array}{l}\text { Section 1 - Instructions to Bidders (ITB) } \\
\text { Section 2 - Bid Data Sheet (BDS) } \\
\text { Section 3 - Evaluation and Qualification Criteria (EQC) } \\
\text { Section 4 - Bidding Forms (BDF) } \\
\text { Section 5 - Eligible Countries (ELC) } \\
\text { Section 6 - Employer's Requirements (ERQ) } \\
\text { Section 7 - General Conditions of Contract (GCC) } \\
\text { Section 8 - Special Conditions of Contract (SCC) } \\
\text { Section 9 - Contract Forms (COF) }\end{array}$ \\
\hline
\end{tabular}

\begin{tabular}{|c|c|c|c|}
\hline & \multicolumn{2}{|r|}{ The Bid } & Submitted by Bidder \\
\hline & a) & \multicolumn{2}{|l|}{ Letter of Bid } \\
\hline & b) & \multicolumn{2}{|c|}{$\begin{array}{l}\text { Completed schedules as required, including Price Schedules, in accordance with ITB } 12 \\
\text { and ITB } 18\end{array}$} \\
\hline & c) & \multicolumn{2}{|c|}{ Bid Security or Bid-Securing Declaration, in accordance with ITB 21} \\
\hline & d) & \multicolumn{2}{|c|}{ Alternative bids, if permissible, in accordance with ITB 13} \\
\hline & e) & \multicolumn{2}{|c|}{$\begin{array}{l}\text { Written confirmation authorizing the signatory of the Bid to commit the Bidder, in } \\
\text { accordance with ITB } 22.2\end{array}$} \\
\hline & f) & \multicolumn{2}{|c|}{$\begin{array}{l}\text { Documentary evidence in accordance with ITB } 14.1 \text { that the plant and services offered } \\
\text { by the Bidder in its bid or in any alternative bid, if permitted, are eligible }\end{array}$} \\
\hline & g) & \multicolumn{2}{|c|}{$\begin{array}{l}\text { Documentary evidence in accordance with ITB } 15 \text {, the Bidder's eligibility and } \\
\text { qualifications to perform the contract if its Bid is accepted }\end{array}$} \\
\hline & h) & \multicolumn{2}{|l|}{ Technical Proposal in accordance with ITB 17} \\
\hline & i) & \multicolumn{2}{|c|}{$\begin{array}{l}\text { Documentary evidence in accordance with ITB } 16 \text { that the plant and services offered by } \\
\text { the Bidder conform to the Bidding Document }\end{array}$} \\
\hline & j) & \multicolumn{2}{|c|}{$\begin{array}{l}\text { Joint Venture agreement, or letter of intent to enter into a Joint Venture, including a draft } \\
\text { agreement, indicating at least the parts of the Plant to be executed by the respective } \\
\text { partners in the case of a bid submitted by a Joint Venture }\end{array}$} \\
\hline & k) & \multicolumn{2}{|l|}{ List of subcontractors, in accordance with ITB 17.2} \\
\hline & I) & \multicolumn{2}{|l|}{ Other documents required in the BDS } \\
\hline
\end{tabular}




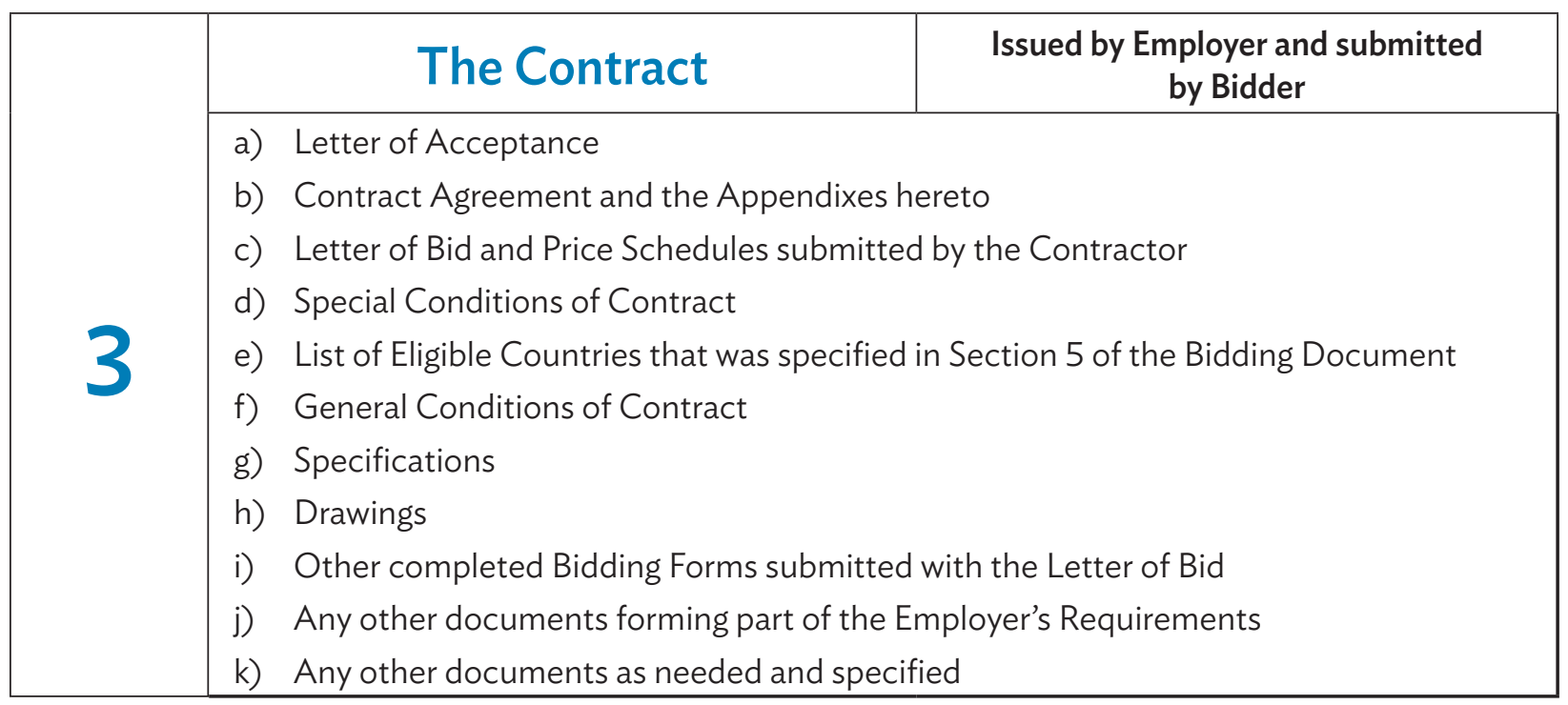




\section{Section 1: Instructions to Bidders}

This section specifies the procedures to be followed by Bidders when preparing and submitting their Bids. Information is also provided on the submission, opening, and evaluation of bids, and award of contract.

\section{Table of Clauses}

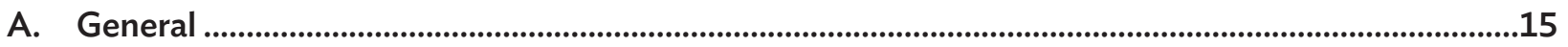

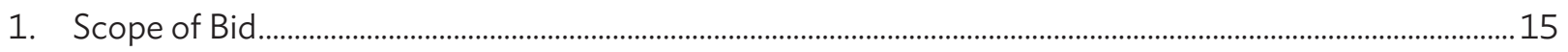

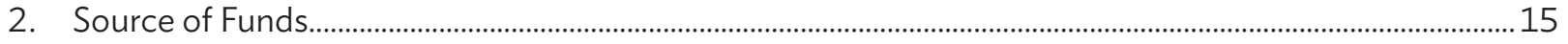

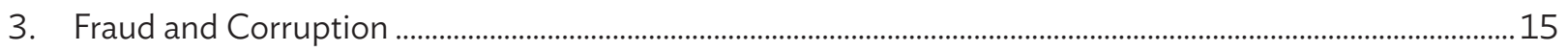

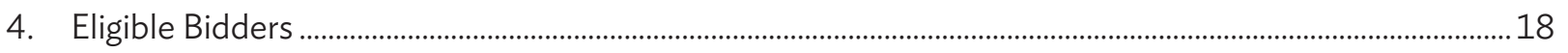

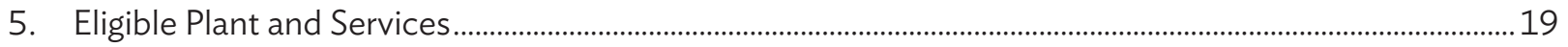

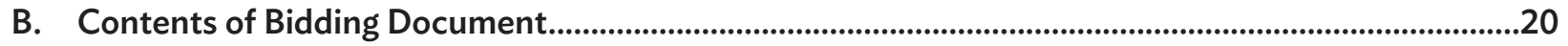

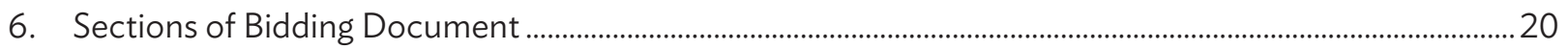

7. Clarification of Bidding Document, Site Visit, Pre-Bid Meeting........................................................................20

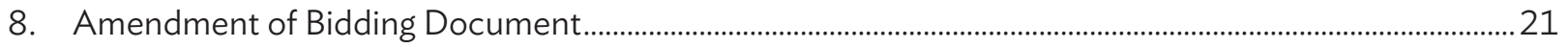

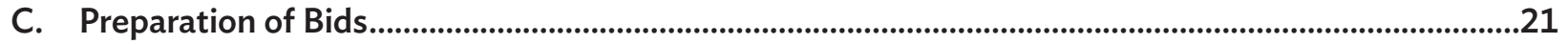

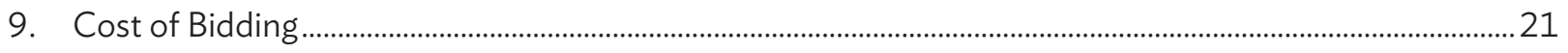

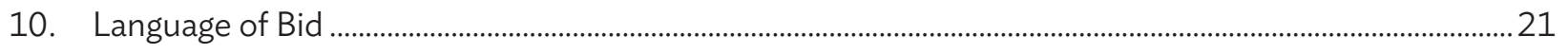

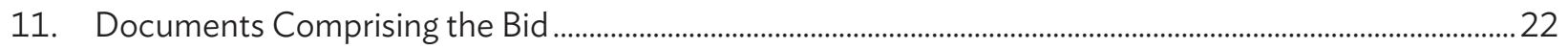

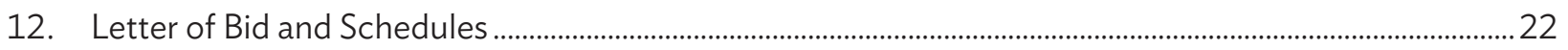

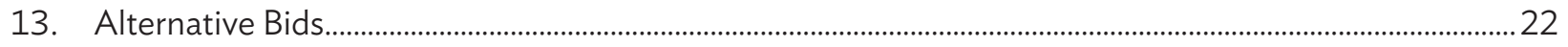

14. Documents Establishing the Eligibility of Plant and Services ...............................................................................23

15. Documents Establishing the Eligibility and Qualifications of the Bidder .....................................................23

16. Documents Establishing Conformity of the Plant and Services.........................................................................23

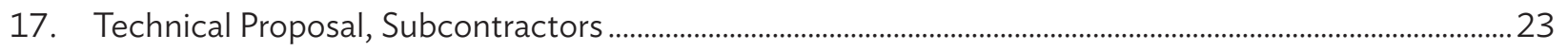

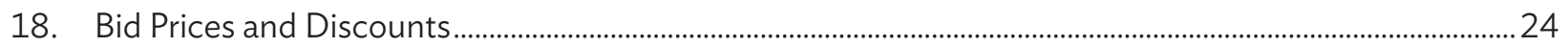

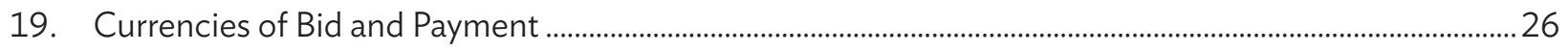

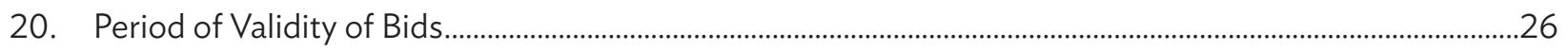




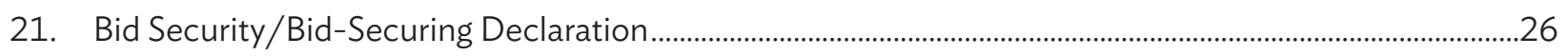

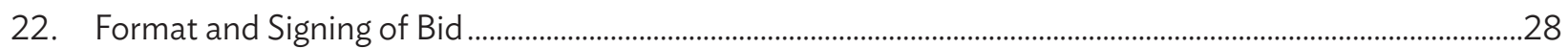

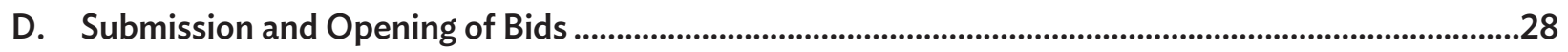

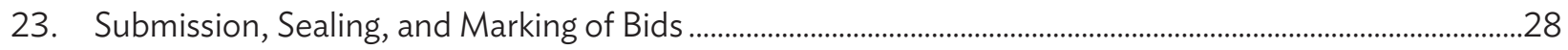

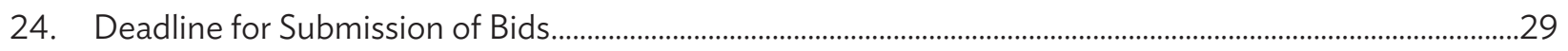

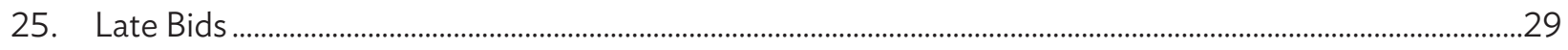

26. Withdrawal, Substitution, and Modification of Bids ........................................................................................29

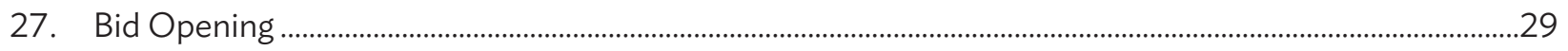

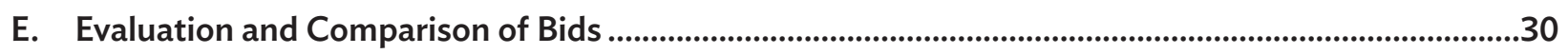

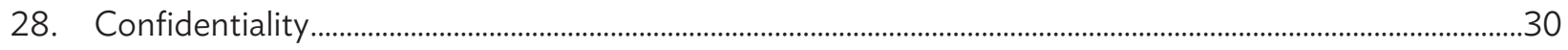

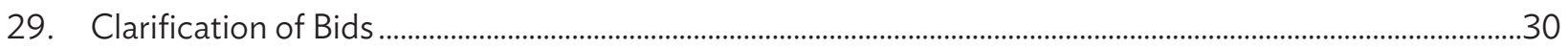

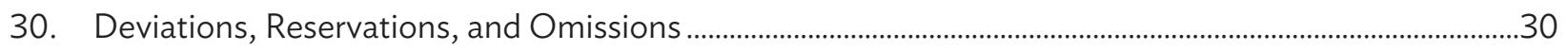

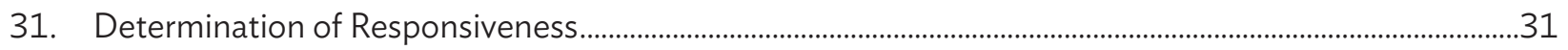

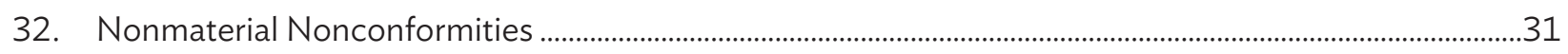

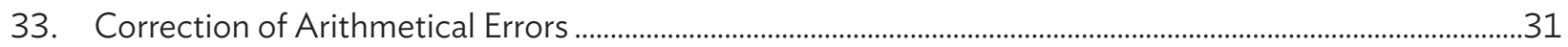

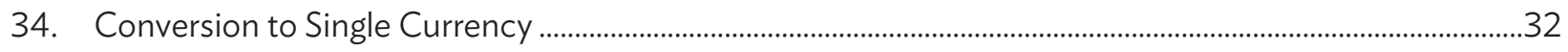

35. Domestic Preference .....................................................................................................................................................

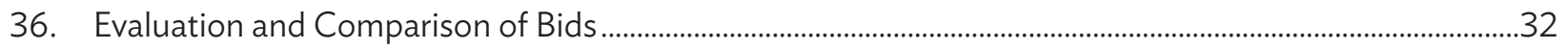

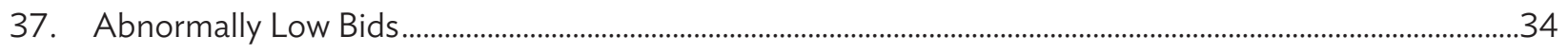

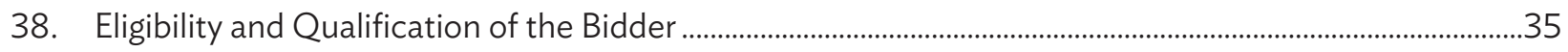

39. Employer's Right to Accept Any Bid and to Reject Any or All Bids .....................................................................35

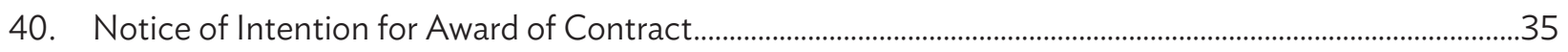

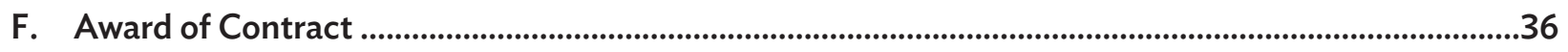

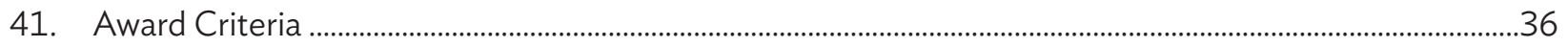

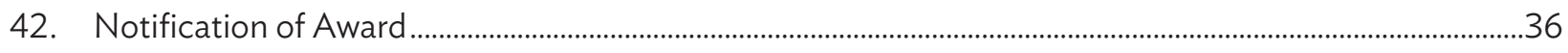

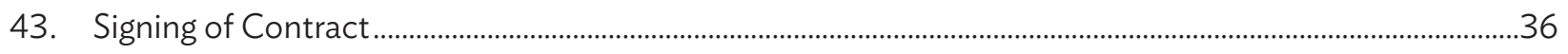

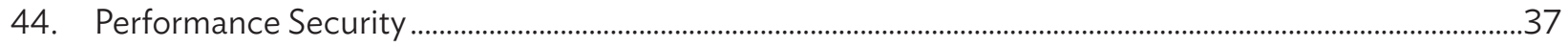

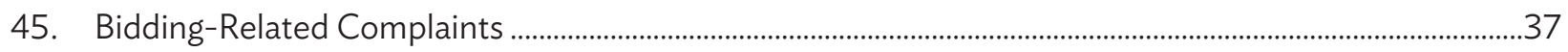




\section{A. General}

1. Scope of Bid

\section{Source of Funds}

\section{Fraud and Corruption}

1.1 In connection with the Invitation for Bids (IFB) indicated in the Bid Data Sheet (BDS), the Employer, as indicated in the BDS, issues this Bidding Document for the procurement of plant and services as specified in Section 6 (Employer's Requirements). The name, identification, and number of lot(s) or contract(s) of the open competitive bidding (OCB) are provided in the BDS.

1.2 Throughout this Bidding Document,

(a) the term "in writing" means communicated in written form and delivered against receipt;

(b) except where the context requires otherwise, words indicating the singular also include the plural and words indicating the plural also include the singular; and

(c) "day" means calendar day.

2.1 The Borrower or Recipient (hereinafter called "Borrower") indicated in the BDS has applied for or received financing (hereinafter called "funds") from the Asian Development Bank (hereinafter called "ADB") toward the cost of the project named in the BDS. The Borrower intends to apply a portion of the funds to eligible payments under the contract(s) for which this Bidding Document is issued.

2.2 Payments by ADB will be made only at the request of the Borrower and upon approval by $A D B$ in accordance with the terms and conditions of the Financing Agreement between the Borrower and ADB (hereinafter called "Financing Agreement"), and will be subject in all respects to the terms and conditions of that Financing Agreement. No party other than the Borrower shall derive any rights from the Financing Agreement or have any claim to the funds.

3.1 ADB requires Borrowers (including beneficiaries of ADB-financed activity) and their personnel, as well as firms and individuals participating in an ADB-financed activity, including but not limited to, Bidders, Suppliers, and Contractors, agents, subcontractors, subconsultants, service providers, subsuppliers, manufacturers (including their respective officers, directors, employees and personnel) under ADB-financed contracts to observe the highest standard of ethics during the procurement and execution of such contracts in accordance with ADB's Anticorruption Policy (1998, as amended from time to time). In pursuance of this policy, ADB

(a) defines, for the purposes of this provision, the terms set forth below as follows:

(i) "corrupt practice" means the offering, giving, receiving, or soliciting, directly or indirectly, anything of value to influence improperly the actions of another party;

(ii) "fraudulent practice" means any act or omission, including a misrepresentation, that knowingly or recklessly misleads, or attempts to mislead, a party to obtain a financial or other benefit or to avoid an obligation;

(iii) "coercive practice" means impairing or harming, or threatening to impair or harm, directly or indirectly, any party or the property of the party to influence improperly the actions of a party; 
(iv) "collusive practice" means an arrangement between two or more parties designed to achieve an improper purpose, including influencing improperly the actions of another party;

(v) "abuse" means theft, waste, or improper use of assets related to ADB-related activity, either committed intentionally or through reckless disregard;

(vi) "conflict of interest" means any situation in which a party has interests that could improperly influence that party's performance of official duties or responsibilities, contractual obligations, or compliance with applicable laws and regulations; and

(vii) "integrity violation" is any act, as defined under ADB's Integrity Principles and Guidelines (2015, as amended from time to time), which violates ADB's Anticorruption Policy, including (i) to (vi) above and the following: obstructive practice, violations of $A D B$ sanctions, retaliation against whistleblowers or witnesses, and other violations of ADB's Anticorruption Policy, including failure to adhere to the highest ethical standard.

(b) will reject a proposal for award if it determines that the Bidder recommended for award or any of its officers, directors, employees, personnel, subconsultants, subcontractors, service providers, suppliers or manufacturers has, directly or through an agent, engaged in corrupt, fraudulent, collusive, coercive, or obstructive practices or other integrity violations in competing for the Contract;

(c) will cancel the portion of the financing allocated to a contract if it determines at any time that representatives of the Borrower or of a beneficiary of ADB-financing engaged in corrupt, fraudulent, collusive, coercive, or obstructive practices or other integrity violations during the procurement or the execution of that contract, without the Borrower having taken timely and appropriate action satisfactory to $A D B$ to remedy the situation, including by failing to inform $A D B$ in a timely manner at the time they knew of the integrity violations;

(d) will impose remedial actions on a firm or an individual, at any time, in accordance with ADB's Anticorruption Policy and Integrity Principles and Guidelines, including declaring ineligible, either indefinitely or for a stated period of time, to participate ${ }^{1}$ in ADB-financed,-administered, or -supported activities or to benefit from an ADB-financed, -administered, or-supported contract, financially or otherwise, if it at any time determines that the firm or individual has, directly or through an agent, engaged in corrupt, fraudulent, collusive, coercive, or obstructive practices, or other integrity violations; and

(e) will have the right to require that a provision be included in the Bidding Documents and in contracts financed, administered, or supported by ADB, requiring Bidders, suppliers, and contractors, consultants, manufacturers, service providers and other third parties engaged or involved in ADB-related activities, and their respective officers, directors, employees and personnel, to permit ADB or its representative to inspect the site and their assets, accounts and records and other documents relating to the bid submission and contract performance and to have them audited by auditors appointed by ADB.

Whether as a Contractor, Subcontractor, Consultant, Manufacturer or Supplier, or Service Provider; or in any other capacity (different names are used depending on the particular Bidding Document). 
3.2 All Bidders, consultants, contractors, suppliers, manufacturers, service providers, and other third parties engaged or involved in ADB-related activities, and their respective officers, directors, employees, and personnel, are obliged to cooperate fully in any investigation when requested by $A D B$ to do so. As determined on a case by case basis by ADB, such cooperation includes, but is not limited to, the following:

(a) being available to be interviewed and replying fully and truthfully to all questions asked;

(b) providing $\mathrm{ADB}$ with any items requested that are within the party's control including, but not limited to, documents and other physical objects;

(c) upon written request by $A D B$, authorizing other related entities to release directly to $A D B$ such information that is specifically and materially related, directly or indirectly, to the said entities or issues which are the subject of the investigation;

(d) cooperating with all reasonable requests to search or physically inspect their person and/or work areas, including files, electronic databases, and personal property used on ADB activities, or that utilizes ADB's Information and Communications Technology (ICT) resources or systems (including mobile phones, personal electronic devices, and electronic storage devices such as external disk drives);

(e) cooperating in any testing requested by $A D B$, including but not limited to, fingerprint identification, handwriting analysis, and physical examination and analysis; and

(f) preserving and protecting confidentiality of all information discussed with, and as required by, ADB.

3.3 All Bidders, consultants, contractors and suppliers shall require their officers, directors, employees, personnel, agents to ensure that, in its contract with its subconsultants, subcontractors, and other third parties engaged or involved in ADB-related activities, such subconsultants, subcontractors, and other third parties similarly are obliged to cooperate fully in any investigation when requested by $A D B$ to do so.

3.4 The Employer hereby puts the Bidder on notice that the Bidder or any Joint venture partner of the Bidder (if any) may not be able to receive any payments under the Contract if the Bidder or any of its Joint venture partners, as appropriate, is, or is owned (in whole or in part) by a person or entity subject to applicable sanctions.

3.5 Furthermore, Bidders shall be aware of the provision stated in GCC 9.6 and GCC 42.2.1(c). 
4. Eligible Bidders

4.1 A Bidder may be a natural person, private entity, or government-owned enterprise subject to ITB 4.5-or any combination of them with a formal intent to enter into an agreement or under an existing agreement in the form of a Joint Venture. In the case of a Joint Venture,

(a) all partners shall be jointly and severally liable; and

(b) the Joint Venture shall nominate a Representative who shall have the authority to conduct all business for and on behalf of any and all the partners of the Joint Venture during the bidding process and, in the event the Joint Venture is awarded the Contract, during contract execution.

4.2 A Bidder, and all partners constituting the Bidder, shall have the nationality of an eligible country, in accordance with Section 5 (Eligible Countries). A Bidder shall be deemed to have the nationality of a country if the Bidder is a citizen or is constituted, incorporated, or registered, and operates in conformity with the provisions of the laws of that country. This criterion shall also apply to the determination of the nationality of proposed Subcontractors or Suppliers for any part of the Contract, including related services.

4.3 A Bidder shall not have a conflict of interest. All Bidders found to have a conflict of interest shall be disqualified. A Bidder may be considered to be in a conflict of interest with one or more parties in this bidding process if any of, including but not limited to, the following apply:

(a) they have controlling shareholders in common; or

(b) they receive or have received any direct or indirect subsidy from any of them; or

(c) they have the same legal representative for purposes of this bid; or

(d) they have a relationship with each other, directly or through common third parties, that puts them in a position to have access to material information about or improperly influence the bid of another Bidder, or influence the decisions of the Employer regarding this bidding process; or

(e) a Bidder participates in more than one bid in this bidding process, either individually or as a partner in a Joint Venture, except for alternative offers permitted under ITB 13. This will result in the disqualification of all Bids in which it is involved. However, subject to any finding of a conflict of interest in terms of ITB 4.3(a)-(d) above, this does not limit the participation of a Bidder as a Subcontractor in another Bid or of a firm as a subcontractor in more than one Bid; or

(f) a Bidder, Joint Venture partner, associates, parent company, or any affiliated entity, participated as a consultant in the preparation of the design or technical specifications of the plant and services that are the subject of the Bid; or

(g) a Bidder was affiliated with a firm or entity that has been hired (or is proposed to be hired) by the Employer or Borrower as Project Manager for the Contract; or 
(h) a Bidder would be providing goods, works, or nonconsulting services resulting from or directly related to consulting services for the preparation or implementation of the project specified in the BDS ITB 2.1 that it provided or were provided by any affiliate that directly or indirectly controls, is controlled by, or is under common control with that firm; or

(i) A Bidder that has a financial or familial relationship with staff of the Employer including project implementing/executing agency, or of a recipient of a part of the loan who: (i) are directly or indirectly involved in the preparation of the bidding documents or specifications of the contract, and/or the bid evaluation process of such contract; or (ii) would be involved in the implementation or supervision of such contract unless the conflict stemming from such relationship has been resolved in a manner acceptable to ADB throughout the procurement process and execution of the contract.

4.4 A firm will not be eligible to participate in any procurement activities under an ADB-financed, -administered, or -supported project while under temporary suspension or debarment by ADB pursuant to its Anticorruption Policy (see ITB 3), whether such debarment was directly imposed by $A D B$, or enforced by $A D B$ pursuant to the Agreement for Mutual Enforcement of Debarment Decisions. A bid from a temporary suspended or debarred firm will be rejected and such bid may be in breach of debarment conditions, thereby subject to further ADB's investigation.

4.5 Government-owned enterprises in the Borrower's country shall be eligible only if they can establish that they (i) are legally and financially autonomous, (ii) operate under commercial law, and (iii) are not dependent agencies of the Employer.

4.6 A Bidder shall not be under suspension from bidding by the Employer as the result of the execution of a Bid-Securing Declaration.

4.7 Bidders shall provide such evidence of their continued eligibility satisfactory to the Employer, as the Employer shall reasonably request.

4.8 Bidders shall be excluded if, by an act of compliance with a decision of the United Nations Security Council taken under Chapter VII of the Charter of the United Nations, the Borrower's country prohibits any import of goods from, or payments to, a particular country, person, or entity in respect of goods or services originating in that country. Where the Borrower's country prohibits payments to a particular person or entity or for particular goods or services by such an act of compliance, that firm shall be excluded.

5. Eligible Plant and Services
5.1 The plant and services to be supplied under the Contract shall have their origin in eligible source countries as defined in ITB 4.2 and all expenditures under the Contract will be limited to such plant and services.

5.2 For purposes of ITB 5.1 above, "origin" means the place where the plant, or component parts thereof are mined, grown, produced, or manufactured, and from which the services are provided. Plant components are produced when, through manufacturing, processing, or substantial or major assembling of components, a commercially recognized product result that differs substantially in its basic characteristics or in purpose or utility from its components. 


\section{B. Contents of Bidding Document}

6. Sections of Bidding Document

7. Clarification of Bidding Document, Site Visit, Pre-Bid Meeting
6.1 The Bidding Document consists of Parts I, II, and III, which include all the sections indicated below, and should be read in conjunction with any addenda issued in accordance with ITB 8.

\section{PART I Bidding Procedures}

- Section 1 Instructions to Bidders (ITB)

- Section 2 Bid Data Sheet (BDS)

- Section 3 Evaluation and Qualification Criteria (EQC)

- Section 4 Bidding Forms (BDF)

- Section 5 Eligible Countries (ELC)

\section{PART II Requirements}

- Section 6 Employer's Requirements (ERQ)

\section{PART III Conditions of Contract and Contract Forms}

- Section 7 General Conditions of Contract (GCC)

- Section 8 Special Conditions of Contract (SCC)

- Section 9 Contract Forms (COF)

6.2 The IFB issued by the Employer is not part of the Bidding Document.

6.3 The Employer is not responsible for the completeness of the Bidding Document and its addenda, if they were not obtained directly from the source stated by the Employer in the IFB.

6.4 The Bidder is expected to examine all instructions, forms, terms, and specifications in the Bidding Document. Failure to furnish all information or documentation required by the Bidding Document may result in the rejection of the Bid.

7.1 A prospective Bidder requiring any clarification on the Bidding Document shall contact the Employer in writing at the Employer's address indicated in the BDS or raise inquiries during the pre-bid meeting if provided for in accordance with ITB 7.4. The Employer will respond to any request for clarification, provided that such request is received no later than 21 days prior to the deadline for submission of bids. The Employer's response shall be in writing with copies to all Bidders who have acquired the Bidding Document in accordance with ITB 6.3, including a description of the inquiry but without identifying its source. Should the Employer deem it necessary to amend the Bidding Document as a result of a request for clarification, it shall do so following the procedure under ITB 8 and ITB 24.2.

7.2 The Bidder is advised to visit and examine the site where the plant is to be installed and its surroundings and obtain for itself on its own responsibility all information that may be necessary for preparing the Bid and entering into a contract for the provision of plant and services. The cost of visiting the site shall be at the Bidder's own expense. 
7.3 The Bidder and any of its personnel or agents will be granted permission by the Employer to enter its premises and lands for the purpose of such visit, but only upon the express condition that the Bidder, its personnel, and agents, will release and indemnify the Employer and its personnel and agents from and against all liability in respect thereof, and will be responsible for death or personal injury, loss of or damage to property, and any other loss, damage, costs, and expenses incurred as a result of the inspection.

7.4 The Bidder's designated representative is invited to attend a pre-bid meeting, if provided for in the BDS. The purpose of the meeting will be to clarify issues and to answer questions on any matter that may be raised at that stage.

7.5 The Bidder is requested to submit any questions in writing, to reach the Employer not later than 1 week before the meeting.

7.6 Minutes of the pre-bid meeting, including the text of the questions raised, without identifying the source, and the responses given, together with any responses prepared after the meeting, will be transmitted promptly to all Bidders who have acquired the Bidding Document in accordance with ITB 6.3. Any modification to the Bidding Document that may become necessary as a result of the pre-bid meeting shall be made by the Employer exclusively through the issue of an addendum pursuant to ITB 8 and not through the minutes of the pre-bid meeting.

7.7 Nonattendance at the pre-bid meeting will not be a cause for disqualification of a Bidder.

\section{Amendment of Bidding Document}

8.1 At any time prior to the deadline for submission of Bids, the Employer may amend the Bidding Document by issuing addenda.

8.2 Any addendum issued shall be part of the Bidding Document and shall be communicated in writing to all who have obtained the Bidding Document from the Employer in accordance with ITB 6.3.

8.3 To give prospective Bidders reasonable time in which to take an addendum into account in preparing their Bids, the Employer may, at its discretion, extend the deadline for the submission of Bids, pursuant to ITB 24.2.

\section{Preparation of Bids}

9. Cost of Bidding

10. Language of Bid
9.1 The Bidder shall bear all costs associated with the preparation and submission of its Bid, and the Employer shall in no case be responsible or liable for those costs, regardless of the conduct or outcome of the bidding process.

10.1 The Bid, as well as all correspondence and documents relating to the bid exchanged by the Bidder and the Employer, shall be written in the language specified in the BDS. Supporting documents and printed literature that are part of the Bid may be in another language provided they are accompanied by an accurate translation of the relevant passages into the language specified in the BDS, in which case, for purposes of interpretation of the Bid, such translation shall govern. 


\section{Documents Comprising the Bid}

\section{Letter of Bid and Schedules}

\section{Alternative Bids}

11.1 The Bid submitted by the Bidder shall comprise the following:

(a) Letter of Bid;

(b) completed schedules as required, including Price Schedules, in accordance with ITB 12 and ITB 18;

(c) Bid Security or Bid-Securing Declaration, in accordance with ITB 21;

(d) alternative Bids, if permissible, in accordance with ITB 13;

(e) written confirmation authorizing the signatory of the Bid to commit the Bidder, in accordance with ITB 22.2;

(f) documentary evidence in accordance with ITB 14.1, that the plant and services offered by the Bidder in its Bid or in any alternative Bid, if permitted, are eligible;

(g) documentary evidence in accordance with ITB 15, the Bidder's eligibility and qualifications to perform the contract if its Bid is accepted;

(h) Technical Proposal in accordance with ITB 17;

(i) documentary evidence in accordance with ITB 16, that the plant and services offered by the Bidder conform to the Bidding Document;

(j) list of Subcontractors, in accordance with ITB 17.2; and

(k) any other document required in the BDS.

11.2 In addition to the requirements under ITB 11.1, Bids submitted by a Joint Venture shall include a copy of the Joint Venture Agreement entered into by all partners. Alternatively, a Letter of Intent to execute a Joint Venture Agreement in the event of a successful Bid shall be signed by all partners and submitted with the Bid, together with a copy of the proposed agreement.

12.1 The Bidder shall complete the Letter of Bid, including the appropriate Price Schedules, using the relevant forms furnished in Section 4 (Bidding Forms). The forms must be completed as instructed in each form and as required in the BDS.

13.1 The BDS indicates whether alternative Bids are allowed. If they are allowed, the BDS will also indicate whether they are permitted in accordance with ITB 13.3, or invited in accordance with ITB 13.2 and/or ITB 13.4.

13.2 When alternatives to the Time Schedule are explicitly invited, a statement to that effect will be included in the BDS, and the method of evaluating different time schedules will be described in Section 3 (Evaluation and Qualification Criteria).

13.3 Except as provided under ITB 13.4 below, Bidders wishing to offer technical alternatives to the Employer's requirements as described in the Bidding Document must also provide (i) a price at which they are prepared to offer a plant meeting the Employer's requirements; and (ii) all information necessary for a complete evaluation of the alternatives by the Employer, including drawings, design calculations, technical specifications, breakdown of prices, and proposed installation methodology and other relevant details. Only the technical alternatives, if any, of the lowest evaluated Bidder conforming to the basic technical requirements shall be considered by the Employer. 
13.4 When Bidders are invited in the BDS to submit alternative technical solutions for specified parts of the facilities, such parts shall be described in Section 6 (Employer's Requirements). Technical alternatives that comply with the performance and technical criteria specified for the plant and services shall be considered by the Employer on their own merits, pursuant to ITB 36.

14. Documents

Establishing the Eligibility of Plant and Services

15. Documents Establishing the Eligibility and Qualifications of the Bidder

\section{Documents Establishing Conformity of the Plant and Services}

\section{Technical Proposal, Subcontractors}

14.1 To establish the eligibility of the plant and services in accordance with ITB 5, Bidders shall complete the country of origin declarations in the Price Schedule Forms, included in Section 4 (Bidding Forms).

15.1 To establish its eligibility and qualifications to perform the Contract in accordance with Section 3 (Evaluation and Qualification Criteria), the Bidder shall provide the information requested in the corresponding information sheets included in Section 4 (Bidding Forms).

15.2 Domestic Bidders, individually or in Joint Ventures, applying for eligibility for domestic preference shall supply all information required to satisfy the criteria for eligibility as described in ITB 35.

16.1 The documentary evidence of the conformity of the plant and services to the Bidding Document may be in the form of literature, drawings, and data, and shall furnish

(a) a detailed description of the essential technical and performance characteristics of the plant and services, including the functional guarantees of the proposed plant and services, in response to the specification;

(b) a list giving full particulars, including available sources, of all spare parts, or special tools necessary for the proper and continuing functioning of the plant for the period stated in the BDS, following completion of plant and services in accordance with provisions of the contract; and

(c) a commentary on the Employer's Specifications and adequate evidence demonstrating the substantial responsiveness of the plant and services to those specifications. Bidders shall note that standards for workmanship, materials, and equipment designated by the Employer in the Bidding Document are intended to be descriptive (establishing standards of quality and performance) only and not restrictive. The Bidder may substitute alternative standards, brand names, and/or catalog numbers in its Bid, provided that it demonstrates to the Employer's satisfaction that the substitutions are substantially equivalent or superior to the standards designated in the Specifications.

17.1 The Bidder shall furnish a Technical Proposal, including a statement of work methods, equipment, personnel, schedule, environmental, health and safety (EHS) management plan commensurate with the proposed scope of works, EHS Code of Conduct, and any other information as stipulated in Section 4 (Bidding Forms), in sufficient detail to demonstrate the adequacy of the Bidders' proposal to meet the work requirements and the completion time. 
17.2 For major items of plant and services as listed by the Employer in Criterion 2.5 of Section 3 (Evaluation and Qualification Criteria), which the Bidder intends to purchase or subcontract, the Bidder shall give details of the name and nationality of the proposed Subcontractors, including Manufacturers, for each of those items. In addition, the Bidder shall include in its Bid information establishing compliance with the requirements specified by the Employer for these items. Bidders are free to list more than one Subcontractor against each item of the plant and services. Quoted rates and prices will be deemed to apply to whichever Subcontractor is appointed, and no adjustment of the rates and prices will be permitted.

17.3 The Bidder shall be responsible for ensuring that any Subcontractor proposed complies with the requirements of ITB 4, and that any plant or services to be provided by the Subcontractor comply with the requirements of ITB 5 and ITB 15.1.

\section{Bid Prices and Discounts}

18.1 Unless otherwisespecified in the BDS and/or Section6(Employer's Requirements), Bidders shall quote for the entire plant and services on a "single responsibility" basis such that the total Bid price covers all the Contractor's obligations mentioned in or to be reasonably inferred from the Bidding Document in respect of the design, manufacture, including procurement and subcontracting (if any), delivery, construction, installation, and completion of the plant. This includes all requirements under the Contractor's responsibilities for testing, pre-commissioning, and commissioning of the plant and, where so required by the Bidding Document, the acquisition of all permits, approvals, and licenses, etc.; the operation, maintenance, and training services and such other items and services as may be specified in the Bidding Document, all in accordance with the requirements of the General Conditions. Items against which no price is entered by the Bidder will not be paid for by the Employer when executed and shall be deemed to be covered by the prices for other items.

18.2 Bidders are required to quote the price for the commercial, contractual, and technical obligations outlined in the Bidding Document. The prices for all items in the Price Schedules shall be expressed in positive values. If the prices are expressed in negative values, the bid will be rejected.

18.3 Bidders shall give a breakdown of the prices in the manner and detail called for in the Price Schedules included in Section 4 (Bidding Forms). Where no different Price Schedules are included in the Bidding Document, Bidders shall present their prices in the following manner: Separate numbered Schedules included in Section 4 (Bidding Forms) shall be used for each of the following elements. The total amount from each Schedule (Nos. 1 to 4) shall be summarized in a Grand Summary (Schedule No. 5), giving the total bid price(s) to be entered in the Letter of Bid. Absence of the total bid price in the Letter of Bid may result in the rejection of the Bid.

Schedule No. 1: Plant and Mandatory Spare Parts Supplied from Abroad

Schedule No. 2: Plant and Mandatory Spare Parts Supplied from Within the Employer's Country

Schedule No. 3: Design Services

Schedule No. 4: Installation and Other Services

Schedule No. 5: Grand Summary (Schedule Nos. 1 to 4)

Schedule No. 6: Recommended Spare Parts 
Bidders shall note that the plant and mandatory spare parts included in Schedule Nos. 1 and 2 above exclude materials used for civil, building, and other construction works. All such materials shall be included and priced under Schedule No. 4, Installation and Other Services.

18.4 In the Schedules, Bidders shall give the required details and a breakdown of their prices as follows:

(a) Plant to be Supplied from Abroad (Schedule No. 1):

(i) the price of the plant shall be quoted carriage and insurance paid (CIP)-named place of destination basis specified in the BDS;

(ii) all customs duties and other taxes paid or payable in the Employer's country on the plant if the contract is awarded to the Bidder; and

(iii) the total price for the plant.

(b) Plant Supplied from Within the Employer's Country (Schedule No. 2):

(i) the price of the plant shall be quoted on an EXW Incoterm basis (ex works, ex factory, ex warehouse, ex showroom, as applicable), including all customs duties and sales and other taxes already paid or payable on the components and raw material used in the manufacture or assembly of plant quoted ex works or ex factory, or on the previously imported plant of foreign origin quoted ex warehouse, ex showroom;

(ii) sales tax and other taxes payable in the Employer's country on the plant if the contract is awarded to the Bidder; and

(iii) the total price for the plant.

(c) Design Services (Schedule No. 3). Rates or prices shall include all taxes, duties, levies, and charges payable in the Employer's country as of 28 days prior to the deadline for submission of Bids.

(d) Installation and Other Services (Schedule No. 4) shall be quoted separately and shall include rates or prices for local transportation, insurance, and other services incidental to delivery of the plant, all labor, contractor's equipment, temporary works, materials, consumables, and all matters and things of whatsoever nature, including operations and maintenance services, the provision of operations and maintenance manuals, training, etc., where identified in the Bidding Document, as necessary for the proper execution of the installation and other services, including all taxes, duties, levies, and charges payable in the Employer's country as of 28 days prior to the deadline for submission of bids.

(e) Recommended spare parts (Schedule No. 6) shall be quoted separately as specified in either subparagraph (a) or (b) above in accordance with the origin of the spare parts.

18.5 The current edition of Incoterms, published by the International Chamber of Commerce shall govern. 
18.6 The prices shall be either fixed or adjustable as specified in the BDS.

(a) In the case of Fixed Price, prices quoted by the Bidder shall be fixed during the Bidder's performance of the contract and not subject to variation on any account. A Bid submitted with an adjustable price quotation will be treated as nonresponsive and rejected.

(b) In the case of Adjustable Price, prices quoted by the Bidder shall be subject to adjustment during performance of the contract to reflect changes in the cost elements such as labor, material, transport, and contractor's equipment in accordance with the procedures specified in the corresponding appendix to the Contract Agreement. A Bid submitted with a fixed price quotation will be treated as nonresponsive and be rejected. The Bidder shall furnish the indexes (e.g., for labor and materials), their weightings and source in the Tables of Adjustment Data included in Section 4 (Bidding Forms). The Employer may require the Bidder to justify its proposed indexes and weightings. Any bid that omits indexes and weightings shall be subject to clarification with the Bidder.

18.7 If so indicated in BDS 1.1, Bids are being invited for individual lots (contracts) or for any combination of lots (packages). Bidders wishing to offer any price reduction (discount) for the award of more than one contract shall specify in their Letter of Bid the price reductions applicable to each package, or alternatively, to individual contracts within the package, and the manner in which the price reductions will apply.

19. Currencies of Bid and Payment

\section{Period of Validity of Bids}

\section{Bid Security/ Bid-Securing Declaration}

19.1 The currency(ies) of the bid shall be, as specified in the BDS.

19.2 Bidders may be required by the Employer to justify, to the Employer's satisfaction, their local and foreign currency requirements.

20.1 Bids shall remain valid for the bid validity period specified in the BDS. The bid validity period starts from the date fixed for the bid submission deadline date prescribed by the Employer in accordance with ITB 24.1. A bid valid for a shorter period shall be rejected by the Employer as nonresponsive.

20.2 In exceptional circumstances, prior to the expiration of the bid validity period, the Employer may request Bidders to extend the period of validity of their Bids. The request and the responses shall be made in writing. If a bid security is requested in accordance with ITB 21 , it shall also be extended 28 days beyond the deadline of the extended bid validity period. A Bidder may refuse the request without forfeiting its bid security. A Bidder granting the request shall not be required or permitted to modify its Bid.

21.1 Unless otherwise specified in the BDS, the Bidder shall furnish as part of its Bid, in original form, either a Bid-Securing Declaration or a bid security as specified in the BDS. In the case of a bid security, the amount and currency shall be as specified in the BDS.

21.2 If a Bid-Securing Declaration is required pursuant to ITB 21.1, it shall use the form included in Section 4 (Bidding Forms). The Employer will declare a Bidder ineligible to be awarded a Contract for a specified period of time, as indicated in the BDS, if a Bid-Securing Declaration is executed. 
21.3 If a bid security is specified pursuant to ITB 21.1 , bid security shall be, at the Bidder's option, in any of the following forms:

(a) an unconditional bank guarantee (hard copy of the bank guarantee or in the form of SWIFT message MT760), or

(b) an irrevocable letter of credit, or

(c) a cashier's or certified check,

all from a reputable source from an eligible country as described in Section 5 (Eligible Countries). In the case of a bank guarantee, the bid security shall be submitted using either the Bid Security Form included in Section 4 (Bidding Forms) or another form acceptable to the Employer. The form must include the complete name of the Bidder. The bid security shall be valid for 28 days beyond the original validity period of the Bid, or beyond any period of extension if requested under ITB 20.2.

21.4 Unless otherwise specified in the BDS, any Bid not accompanied by a substantially compliant bid security or Bid-Securing Declaration, if one is required in accordance with ITB 21.1, shall be rejected by the Employer as nonresponsive.

21.5 If a bid security is specified pursuant to ITB 21.1, the bid security of unsuccessful Bidders shall be returned promptly upon the successful Bidder's furnishing of the performance security pursuant to ITB 44.

21.6 If a bid security is specified pursuant to ITB 21.1, the bid security of the successful Bidder shall be returned promptly once the successful Bidder has signed the Contract and furnished the required performance security.

21.7 The bid security may be forfeited or the Bid-Securing Declaration executed, if

(a) notwithstanding ITB 26.3, a Bidder withdraws its Bid during the period of bid validity specified by the Bidder on the Letter of Bid, except as provided in ITB 20.2 , or

(b) the successful Bidder fails to

(i) sign the Contract in accordance with ITB 43,

(ii) furnish a performance security in accordance with ITB 44, or

(iii) accept the arithmetical corrections of its Bid in accordance with ITB 33.

21.8 If the bid security is required as per ITB 21.1, the bid security of a Joint Venture shall be in the name of the Joint Venture that submits the Bid. If the Joint Venture has not been legally constituted at the time of bidding, the bid security shall be in the name of any or all of the Joint Venture partners. If the Bid-Securing Declaration is required as per ITB 21.1, the Bid-Securing Declaration of a Joint Venture shall be in the name of the Joint Venture that submits the Bid. If the Joint Venture has not been legally constituted at the time of bidding, the Bid-Securing Declaration shall be in the names of all future partners as named in the letter of intent referred to in ITB 4.1. 


\section{Format and Signing of Bid}

22.1 The Bidder shall prepare one original set of the documents comprising the Bid as described in ITB 11 and clearly mark it "ORIGINAL." Alternative Bids, if permitted in accordance with ITB 13, shall be clearly marked "ALTERNATIVE." In addition, the Bidder shall submit copies of the Bid, in the number specified in the BDS and clearly mark them "COPY." In the event of any discrepancy between the original and the copies, the original shall prevail.

22.2 The original and all copies of the Bid shall be typed or written in indelible ink and shall be signed by a person duly authorized to sign on behalf of the Bidder. This authorization shall consist of a written confirmation as specified in the BDS and shall be attached to the Bid. The name and position held by each person signing the authorization must be typed or printed below the signature. If a Bidder submits a deficient authorization, the Bid shall not be rejected in the first instance. The Employer shall request the Bidder to submit an acceptable authorization within the number of days as specified in the BDS. Failure to provide an acceptable authorization within the period stated in the Employer's request shall cause the rejection of the Bid. If either the Letter of Bid or the Bid-Securing Declaration (if applicable) is not signed, the Bid shall be rejected.

22.3 A Bid submitted by a Joint Venture shall be signed so as to be legally binding on all partners.

22.4 Any amendments such as interlineations, erasures, or overwriting shall be valid only if they are signed or initialed by the person signing the Bid.

\section{Submission and Opening of Bids}

23. Submission, Sealing, and Marking of Bids
23.1 Bidders shall submit their Bids as specified in the BDS. Procedures for submission, sealing, and marking are as follows:

(a) Bidders submitting Bids by mail or by hand shall enclose the original and each copy of the Bid, including alternative Bids, if permitted in accordance with ITB 13, in separate sealed envelopes, duly marking the envelopes as "ORIGINAL", "ALTERNATIVE," and "COPY." These envelopes containing the original and the copies shall then be enclosed in one single envelope. The rest of the procedure shall be in accordance with ITB 23.2 and ITB 23.3.

(b) Bidders submitting Bids electronically shall follow the electronic bid submission procedures specified in the BDS.

23.2 The inner and outer envelopes shall

(a) bear the name and address of the Bidder,

(b) be addressed to the Employer in accordance with ITB 24.1,

(c) bear the specific identification of this bidding process indicated in the BDS 1.1, and

(d) bear a warning not to open before the time and date for bid opening.

23.3 If all envelopes are not sealed and marked as required, the Employer will assume no responsibility for the misplacement or premature opening of the Bid. 
24. Deadline for Submission of Bids

\section{Late Bids}

\section{Withdrawal, Substitution, and Modification of Bids}

\section{Bid Opening}

24.1 Bids must be received by the Employer at the address and no later than the date and time indicated in the BDS.

24.2 The Employer may, at its discretion, extend the deadline for the submission of bids by amending the Bidding Document in accordance with ITB 8, in which case all rights and obligations of the Employer and Bidders previously subject to the deadline shall thereafter be subject to the deadline as extended.

25.1 The Employer shall not consider any Bid that arrives after the deadline for submission of Bids, in accordance with ITB 24. Any Bid received by the Employer after the deadline for submission of Bids shall be declared late, rejected, and returned unopened to the Bidder.

26.1 A Bidder may withdraw, substitute, or modify its Bid after it has been submitted by sending a written notice, duly signed by an authorized representative, and shall include a copy of the authorization in accordance with ITB 22.2 (except for withdrawal notices, which do not require copies). The corresponding substitution or modification of the Bid must accompany the respective written notice. All notices must be

(a) prepared and submitted in accordance with ITB 22 and ITB 23 (except for withdrawal notices, which do not require copies), and in addition, the respective envelopes shall be clearly marked "WITHDRAWAL," "SUBSTITUTION," "MODIFICATION;" and

(b) received by the Employer prior to the deadline prescribed for submission of Bids, in accordance with ITB 24.

26.2 Bids requested to be withdrawn in accordance with ITB 26.1 shall be returned unopened to the Bidders.

26.3 No Bid may be withdrawn, substituted, or modified in the interval between the deadline for submission of Bids and the expiration of the period of bid validity specified by the Bidder on the Letter of Bid or any extension thereof.

27.1 The Employer shall open the Bids in public at the address, on the date, and time specified in the BDS in the presence of Bidders ' designated representatives and anyone who choose to attend. Any specific electronic bid opening procedures required if electronic bidding is permitted in accordance with ITB 23.1, shall be as specified in the BDS.

27.2 First, envelopes marked "WITHDRAWAL" shall be opened and read out and the envelope with the corresponding Bid shall not be opened, but returned to the Bidder. No bid withdrawal shall be permitted unless the corresponding withdrawal notice contains a valid authorization to request the withdrawal and is read out at bid opening. Next, envelopes marked "SUBSTITUTION" shall be opened and read out and exchanged with the corresponding Bid being substituted. The substituted Bid shall not be opened, but returned to the Bidder. No bid substitution shall be permitted unless the corresponding substitution notice contains a valid authorization to request the substitution and is read out at bid opening. Envelopes marked "MODIFICATION" shall be opened and read out with the corresponding Bid. No bid modification shall be permitted unless the corresponding modification notice contains a valid authorization to request the modification and is read out at bid opening. Only envelopes that are opened and read out at bid opening shall be considered further. 
27.3 All other envelopes shall be opened one at a time, reading out the name of the Bidder and whether there is a modification; the Bid Price(s), including any discounts and alternative Bids; the presence of a bid security, or a Bid-Securing Declaration, if required; and any other details as the Employer may consider appropriate. Only discounts and alternative Bids read out at bid opening shall be considered for evaluation. Unless otherwise specified in the BDS, all pages of the Letter of Bid and Price Schedules are to be initialed by at least three representatives of the Employer attending the bid opening. No Bid shall be rejected at bid opening except for late Bids, in accordance with ITB 25.1.

27.4 The Employer shall prepare a record of the bid opening that shall include, as a minimum: the name of the Bidder and whether there is a withdrawal, substitution, or modification; the Bid Price, per lot if applicable, including any discounts and alternative Bids; and the presence or absence of a bid security or a Bid-Securing Declaration, if one was required. The Bidders' representatives who are present shall be requested to sign the record. The omission of a Bidder's signature on the record shall not invalidate the contents and effect of the record. A copy of the record shall be distributed to all Bidders who submitted Bids on time, and posted online when electronic bidding is permitted.

\section{E. Evaluation and Comparison of Bids}

28. Confidentiality

29. Clarification
of Bids

30. Deviations, Reservations, and Omissions
28.1 Information relating to the evaluation of Bids and recommendation of contract award shall not be disclosed to Bidders or any other persons not officially concerned with such process until the publication of Contract award.

28.2 Any attempt by a Bidder to influence the Employer in the evaluation of the Bids or Contract award decisions may result in the rejection of its Bid.

28.3 Notwithstanding ITB 28.2, from the time of bid opening to the time of Contract award, if any Bidder wishes to contact the Employer on any matter related to the bidding process, it should do so in writing.

29.1 To assist in the examination, evaluation, and comparison of the Bids, and qualification of the Bidders, the Employer may, at its discretion, ask any Bidder for a clarification of its Bid. Any clarification submitted by a Bidder that is not in response to a request by the Employer shall not be considered. The Employer's request for clarification and the response shall be in writing. No change in the prices or substance of the Bid shall be sought, offered, or permitted, except to confirm the correction of arithmetic errors discovered by the Employer in the evaluation of the Bids, in accordance with ITB 33.

29.2 If a Bidder does not provide clarifications of its Bid by the date and time set in the Employer's request for clarification, its Bid may be rejected.

30.1 During the evaluation of Bids, the following definitions apply:

(a) "Deviation" is a departure from the requirements specified in the Bidding Document;

(b) "Reservation" is the setting of limiting conditions or withholding from complete acceptance of the requirements specified in the Bidding Document; and

(c) "Omission" is the failure to submit part or all of the information or documentation required in the Bidding Document. 
31. Determination of Responsiveness

\section{Nonmaterial Nonconformities}

\section{Correction of Arithmetical Errors}

31.1 The Employer's determination of a bid's responsiveness is to be based on the contents of the Bid itself, as defined in ITB 11.

31.2 A substantially responsive Bid is one that meets the requirements of the Bidding Document without material deviation, reservation, or omission. A material deviation, reservation, or omission is one that,

(a) if accepted, would

(i) affect in any substantial way the scope, quality, or performance of the plant and services specified in the Contract; or

(ii) limit in any substantial way, inconsistent with the Bidding Document, the Employer's rights, or the Bidder's obligations under the proposed Contract; or

(b) if rectified, would unfairly affect the competitive position of other Bidders presenting substantially responsive Bids.

31.3 The Employer shall examine the technical aspects of the Bid submitted in accordance with ITB 17, Technical Proposal, in particular, to confirm that all requirements of Section 6 (Employer's Requirements) have been met without any material deviation, reservation, or omission.

31.4 If a Bid is not substantially responsive to the requirements of the Bidding Document, it shall be rejected by the Employer and may not subsequently be made responsive by correction of the material deviation, reservation, or omission.

32.1 Provided that a Bid is substantially responsive, the Employer may waive any nonconformities in the Bid that do not constitute a material deviation, reservation, or omission.

32.2 Provided that a Bid is substantially responsive, the Employer may request that the Bidder submit the necessary information or documentation, within a reasonable period of time, to rectify nonmaterial nonconformities in the Bid related to documentation requirements. Requesting information or documentation on such nonconformities shall not be related to any aspect of the price of the Bid. Failure of the Bidder to comply with the request may result in the rejection of its Bid.

32.3 Provided that a Bid is substantially responsive, the Employer shall rectify quantifiable nonmaterial nonconformities related to the Bid Price. To this effect, the Bid Price shall be adjusted, for comparison purposes only, to reflect the price of a missing or nonconforming item or component. The adjustment shall be made using the method indicated in Section 3 (Evaluation and Qualification Criteria).

33.1 Provided that the Bid is substantially responsive, the Employer shall correct arithmetical errors on the following basis:

(a) where there are errors between the total of the amounts given under the column for the price breakdown and the amount given under the Total Price, the amounts given under the column for the price breakdown shall prevail and the Total Price will be corrected accordingly; 
(b) where there are errors between the total of the amounts of Schedule Nos. 1 to 4 and the amount given in Schedule No. 5 (Grand Summary), the total of the amounts of Schedule Nos. 1 to 4 shall prevail and the Schedule No. 5 (Grand Summary) will be corrected accordingly;

(c) if there is a discrepancy between the grand total price given in Schedule No. 5 (Grand Summary) and the bid amount in item (c) of the Letter of Bid, the grand total price given in Schedule No. 5 (Grand Summary) will prevail and the bid amount in item (c) of the Letter of Bid will be corrected; and

(d) if there is a discrepancy between words and figures, the amount in words shall prevail, unless the amount expressed in words is related to an arithmetical error, in which case the amount in figures shall prevail subject to (a), (b), and (c) above.

33.2 If the Bidder that submitted the lowest evaluated Bid does not accept the correction of errors, its Bid shall be disqualified and its bid security may be forfeited, or its Bid-Securing Declaration executed.

34. Conversion to Single Currency

35. Domestic Preference

36. Evaluation and Comparison of Bids
34.1 For evaluation and comparison purposes, the currency(ies) of the Bid shall be converted into a single currency as specified in the BDS.

35.1 Unless otherwise specified in the BDS, domestic preference shall not apply.

36.1 The Employer shall use the criteria and methodologies indicated in this clause. No other evaluation criteria or methodologies shall be permitted.

\subsection{Technical Evaluation}

The Employer will carry out a detailed technical evaluation of the Bids not previously rejected as being substantially nonresponsive, to determine whether the technical aspects are in compliance with the Bidding Document. The Bid that does not meet required acceptable standards of completeness, consistency and detail, and the specified minimum and/or maximum requirements for specified functional guarantees will be treated as nonresponsive and hence rejected. To reach such a determination, the Employer will examine and compare the technical aspects of the bids on the basis of the information supplied by the Bidders, taking into account the following:

(a) overall completeness and compliance with the Employer's Requirements; deviations from the Employer's Requirements; conformity of the plant and services offered with specified performance criteria; suitability of the plant and services offered in relation to the environmental and climatic conditions prevailing at the site; and quality, function, and operation of any process control concept included in the Bid. The Bid that does not meet minimum and/or maximum acceptable standards of completeness, consistency, and detail will be rejected for nonresponsiveness; 
(b) type, quantity, and long-term availability of mandatory and recommended spare parts and maintenance services; and

(c) other relevant factors, if any, listed in Section 3 (Evaluation and Qualification Criteria).

36.3 Where alternative technical solutions have been allowed in accordance with ITB 13, and offered by the Bidder, the Employer will make a similar evaluation of the alternatives. Where alternatives have not been allowed but have been offered, they shall be ignored.

\subsection{Economic Evaluation}

I. To evaluate a Bid, the Employer shall consider the following:

(a) the bid price, excluding provisional sums and the provision, if any, for contingencies in the Price Schedules;

(b) price adjustment for correction of arithmetical errors in accordance with ITB 33.1;

(c) price adjustment due to discounts offered in accordance with ITB 18.7;

(d) price adjustment due to quantifiable nonmaterial nonconformities in accordance with ITB 32.3;

(e) converting the amount resulting from applying (a) to (c) above, if relevant, to a single currency in accordance with ITB 34;

(f) assessment whether the bid is abnormally low in accordance with ITB 37; and

(g) the evaluation factors indicated in Section 3 (Evaluation and Qualification Criteria).

II. The Employer's evaluation of a Bid will exclude and not take into account,

(a) in the case of Plant and Mandatory Spare Parts (Schedule No. 1) supplied from abroad, all taxes and duties, applicable in the Employer's country and payable on the Plant and Mandatory Spare Parts if the Contract is awarded to the Bidder; and

(b) in the case of Plant and Mandatory Spare Parts (Schedule No. 2) supplied from within the Employer's country, sales and other taxes, applicable in the Employer's country and payable on the Plant and Mandatory Spare Parts if the Contract is awarded to the Bidder.

36.5 If price adjustment is allowed in accordance with ITB 18.6, the estimated effect of the price adjustment provisions of the Conditions of Contract, applied over the period of execution of the Contract, shall not be taken into account in bid evaluation. 
36.6 If this Bidding Document allows Bidders to quote separate prices for different lots (contracts), and the award to a single Bidder of multiple lots (contracts), the methodology to determine the lowest evaluated price of the lot (contract) combinations, including any discounts offered in the Letter of Bid, is specified in Section 3 (Evaluation and Qualification Criteria).

36.7 If the Bid, which results in the lowest Evaluated Bid Price, is seriously unbalanced or front loaded in the opinion of the Employer, the Employer may require the Bidder to produce detailed price analyses for any or all items of the Price Schedules, to demonstrate the internal consistency of those prices with the methods and time schedule proposed. After evaluation of the price analyses, taking into consideration the terms of payments, the Employer may require that the amount of the performance security be increased at the expense of the Bidder to a level sufficient to protect the Employer against financial loss in the event of default of the successful Bidder under the Contract.

36.8 The Employer shall compare all substantially responsive Bids to determine the lowest evaluated Bid price, in accordance with ITB 36.4.

\section{Abnormally Low Bids}

37.1 An abnormally low bid is one where the bid price, in combination with other elements of the bid, appears to be so low that it raises concerns as to the capability of the Bidder to perform the contract for the offered bid price.

37.2 When the offered bid price appears to be abnormally low, the Employer shall undertake a three-step review process as follows:

(a) identify abnormally low costs and unit rates by comparing them with the engineer's estimates, other substantially responsive bids, or recently awarded similar contracts;

(b) clarify and analyze the bidder's resource inputs and pricing, including overheads, contingencies and profit margins; and

(c) decide whether to accept or reject the bid.

37.3 With regard to ITB 37.2 (b) above, the Employer will seek a written explanation from the bidder of the reasons for the offered bid price, including a detailed analysis of costs and unit prices, by reference to the scope, proposed methodology, schedule, and allocation of risks and responsibilities. This may also include information regarding the economy of the manufacturing process; the services to be provided, or the construction method to be used; the technical solutions to be adopted; and any exceptionally favorable conditions available to the bidder for the works, equipment or services proposed.

37.4 After examining the explanation given and the detailed price analyses presented by the bidder, the Employer may:

(a) accept the bid, if the evidence provided satisfactorily accounts for the low bid price and costs, in which case the bid is not considered abnormally low;

(b) accept the bid, but require that the amount of the performance security be increased at the expense of the bidder to a level sufficient to protect the Employer against financial loss. The amount of the performance security shall generally be not more than $20 \%$ of the contract price; or 


\section{Eligibility and Qualification of the Bidder}

39. Employer's Right to Accept Any Bid and to Reject Any or All Bids

40. Notice of Intention for Award of Contract (c) reject the bid if the evidence provided does not satisfactorily account for the low bid price, and make a similar determination for the next ranked bid, if required.

38.1 The Employer shall determine to its satisfaction whether the Bidder that is selected as having submitted the lowest evaluated and substantially responsive Bid is eligible and meets the qualifying criteria specified in Section 3 (Evaluation and Qualification Criteria).

38.2 The determination shall be based upon an examination of the documentary evidence of the Bidder's qualifications submitted by the Bidder, pursuant to ITB 15. Unless permitted in the BDS, the determination shall not take into consideration the qualifications of other firms such as the Bidder's subsidiaries, parent entities, or affiliates.

38.3 An affirmative determination shall be a prerequisite for award of the Contract to the Bidder. The Employer reserves the right to reject the bid of any bidder found to be in circumstances described in GCC 42.2.1(a). A negative determination shall result in disqualification of the Bid, in which event the Employer shall proceed to the next lowest evaluated Bid to make a similar determination of that Bidder's qualifications to perform satisfactorily.

38.4 The capabilities of the manufacturers and subcontractors proposed in its Bid for the major items of plant and services to be used by the lowest evaluated Bidder will also be evaluated for acceptability in accordance with Section 3 (Evaluation and Qualification Criteria). Their participation should be confirmed with a letter of intent between the parties, as needed. Should a manufacturer or subcontractor be determined to be unacceptable, the Bid will not be rejected, but the Bidder will be required to propose, without changing its bid price, an acceptable substitute manufacturer or subcontractor meeting the minimum technical specifications stated in Section 6 (Employer's Requirements). If a Bidder does not provide an acceptable substitute manufacturer or subcontractor by the date and time set in the Employer's request for substitution of manufacturer or subcontractor, its Bid may be rejected.

38.5 Prior to signing the Contract, the corresponding Appendix to the Contract Agreement shall be completed, listing the approved manufacturers or subcontractors for each item concerned.

39.1 The Employer reserves the right to accept or reject any Bid, and to annul the bidding process and reject all Bids at any time prior to contract award, without thereby incurring any liability to Bidders. In case of annulment, all Bids submitted and specifically, bid securities, shall be promptly returned to the Bidders.

40.1 If Standstill provisions apply as specified in the BDS, the standstill period shall be defined in the BDS to specify the duration subsequent to notification of intention for award of contract (before making the actual contract award) within which any unsuccessful bidder can challenge the proposed award. 


\section{F. Award of Contract}

41. Award Criteria

\section{Notification of Award}

41.1 The Employer shall award the Contract to the Bidder whose offer has been determined in line with ITB 36 to ITB 37 above to be the lowest evaluated Bid and is substantially responsive to the Bidding Document, provided further that the Bidder is determined to be eligible and qualified to perform the Contract satisfactorily.

42.1 Prior to the expiration of the period of bid validity and upon expiry of the standstill period specified in ITB 40.1, or upon satisfactory resolution of a complaint filed within standstill period, if applicable, the Employer shall transmit the Notification of Award through the issuance of Letter of Acceptance using the form included in Section 9 (Contract Forms) to the successful Bidder, in writing, that its Bid has been accepted. At the same time, the Employer shall also notify all other Bidders of the results of the bidding.

42.2 Unless a stand still period applies, upon notification of award through the issuance of Letter of Acceptance, unsuccessful Bidders may request in writing to the Employer for a debriefing seeking explanations on the grounds on which their Bids were not selected. The Employer shall promptly respond in writing and/or in a debriefing meeting to any unsuccessful Bidder who, after publication of contract award, requests a debriefing.

42.3 Until a formal contract is prepared and executed, the notification of award through the issuance of Letter of Acceptance shall constitute a binding Contract.

42.4 Within 2 weeks of the award of contract or expiry of the standstill period, where such period applies, or, if a complaint has been filed within the standstill period, upon receipt of ADB's confirmation of satisfactory resolution of the complaint, the borrower shall publish in an English language newspaper or widely known and freely accessible website the results identifying the bid and lot or package numbers, as applicable and the following information:

(a) name of each Bidder who submitted a Bid;

(b) bid prices as read out at bid opening;

(c) name and evaluated prices of each bid that was evaluated;

(d) name of Bidders whose Bids were rejected and the reasons for their rejection; and

(e) name of the winning Bidder, and the price it offered, as well as the duration and summary scope of the contract awarded.

43.1 Promptly after notification, the Employer shall send the successful Bidder the Contract Agreement.

43.2 Within 28 days of receipt of the Contract Agreement, the successful Bidder shall sign, date, and return it to the Employer. 
44. Performance Security

\section{Bidding-Related Complaints}

44.1 Within 28 days of the receipt of notification of award through the issuance of Letter of Acceptance from the Employer, the successful Bidder shall furnish the performance security in accordance with the Conditions of Contract, subject to ITB 36.7 and ITB 37, using for that purpose the Performance Security Form included in Section 9 (Contract Forms), or another form acceptable to the Employer. If the bank issuing performance security is located outside the Employer's country, it shall be counter-guaranteed or encashable by a bank in the Employer's country.

44.2 Failure of the successful Bidder to submit the abovementioned performance security or sign the Contract shall constitute sufficient grounds for the annulment of the award and forfeiture of the bid security or execution of the Bid-Securing Declaration. In that event, the Employer may award the Contract to the next lowest evaluated Bidder whose offer is substantially responsive and is determined by the Employer to be qualified to perform the Contract satisfactorily.

45.1 The procedures for dealing with Bidding-Related Complaints arising out of this bidding process are specified in the BDS. 


\section{Section 2: Bid Data Sheet}

This section consists of provisions that are specific to each procurement and supplement the information or requirements included in Section 1 (Instructions to Bidders).

\section{A. General}

\begin{tabular}{|l|l|}
\hline ITB 1.1 & $\begin{array}{l}\text { The number of the Invitation for Bids (IFB) is: [insert identification number of the IFB] } \\
\text { The Employer is: [insert name of the Employer] }\end{array}$ \\
& $\begin{array}{l}\text { The name of the open competitive bidding (OCB) is: [insert the name of OCB] } \\
\text { The identification number of the OCB is: [insert identification number of the OCB] } \\
\text { The number and identification of lots (contracts) comprising this OCB is: } \\
{[\text { if there are no lots, insert "None." If there are lots, insert a list of lots, identifying each lot by indicating number }} \\
\text { and name of lots or contracts] }\end{array}$ \\
\hline ITB 2.1 & $\begin{array}{l}\text { The Borrower is: [insert name of the borrower] } \\
\text { The name of the Project is: [insert name of the project] }\end{array}$
\end{tabular}

\section{B. Contents of Bidding Document}

\begin{tabular}{|l|l}
\hline ITB 7.1 & $\begin{array}{l}\text { For clarification purposes only, the Employer's address is: } \\
\text { [Insert details below as appropriate] } \\
\text { Attention: [insert full name of the person, if applicable] } \\
\text { Street address: [insert street address and number] } \\
\text { Floor/Room number: [insert floor and room number, if applicable] } \\
\text { City: [insert name of the city or town }] \\
\text { ZIP code: [insert postal (ZIP) code, if applicable] } \\
\text { Country: [insert name of country] } \\
\text { Telephone: [insert telephone number, including country and city codes] } \\
\text { Fax: [insert fax number, with country and city codes] } \\
\text { E-mail: [insert e-mail address, if applicable] }\end{array}$
\end{tabular}


ITB 7.4

A Pre-Bid meeting [insert "will" or "will not"] take place.

[If a pre-bid meeting takes place, insert date, time, and place below]

Date:

Time:

Place:

A site visit conducted by the Employer [insert "will" or "will not"] be organized.

\section{Preparation of Bids}

\begin{tabular}{|l|l|}
\hline ITB 10.1 & The language of the Bid is: [insert "English"] \\
\hline ITB 11.1(k) & $\begin{array}{l}\text { The Bidder shall submit with its bid the following additional documents: } \\
\text { [insert a list of additional documents if so required] }\end{array}$ \\
\hline ITB 12.1 & $\begin{array}{l}\text { The units and rates in figures entered into the Price Schedules should be typewritten or if } \\
\text { written by hand, must be in print form. Price Schedules not presented accordingly may be } \\
\text { considered nonresponsive. }\end{array}$ \\
\hline ITB 13.1 & $\begin{array}{l}\text { [Choose one of the following options as appropriate.] } \\
\text { Alternative bids are invited in accordance with ITB 13.2 and/or 13.4 [specify the type(s) of } \\
\text { alternative accepted in relation to ITB 13.2 and 13.4"] } \\
\text { [or] } \\
\text { Alternative bids are permitted in accordance with ITB 13.3. } \\
\text { [or] } \\
\text { Alternative bids are not permitted. }\end{array}$ \\
\hline ITB 13.2 & $\begin{array}{l}\text { Alternatives to the Time Schedule [insert "shall" or "shall not"] be permitted. } \\
\text { If alternatives to the Time Schedule are permitted, the evaluation method will be as } \\
\text { specified in Section 3 (Evaluation and Qualification Criteria). }\end{array}$ \\
\hline ITB 16.1(b) & $\begin{array}{l}\text { Alternative technical solutions shall be permitted for the following parts of the plant and } \\
\text { services: [insert parts for which alternative technical solutions are permitted] further detailed in the } \\
\text { Specification. If alternative technical solutions are permitted, the evaluation method will } \\
\text { be as specified in Section 3 (Evaluation and Qualification Criteria). }\end{array}$ \\
\hline ITB 13.4 & $\begin{array}{l}\text { The period following completion of plant and services in accordance with provisions of the } \\
\text { contract shall be [insert number of years as appropriate]. }\end{array}$ \\
\hline
\end{tabular}




\begin{tabular}{|c|c|}
\hline ITB 18.1 & $\begin{array}{l}\text { [Choose one of the following options as appropriate] } \\
\text { Bidders shall quote for the entire plant and services on a single responsibility basis. } \\
\text { [or] } \\
\text { Bidders shall quote for the following components or services on a single responsibility } \\
\text { basis: [insert list of components or services] } \\
\text { and/or } \\
\text { The following components or services will be provided under the responsibility of the } \\
\text { Employer: [insert list of components or services] }\end{array}$ \\
\hline ITB 18.4(a)(i) & The Incoterm for quoting plant to be supplied from abroad is: [insert CIP-named place of destination] \\
\hline ITB 18.6 & $\begin{array}{l}\text { The prices quoted by the Bidder shall be [insert "fixed" or "adjustable"] } \\
\text { [If prices are to be adjustable, insert: "The formula for adjusting the prices and explanatory details are } \\
\text { specified in the Special Conditions of Contract (SCC) Clause } 11.2 \text { and Appendix } 2 \text { of Contract Agreement. } \\
\text { Bidder shall fill out the Tables of Adjustment Data in Section } 4 \text { (Bidding Forms)."] } \\
\text { [Use "Adjustable" where the contract period is of long duration (generally exceeds } 18 \text { months). Prices payable } \\
\text { to the contractor shall be subject to price adjustment during the performance of the contract.] } \\
\text { [If prices shall be fixed, the Tables of Adjustment Data in Section } 4 \text { (Bidding Forms) shall be removed.] }\end{array}$ \\
\hline \multirow[t]{4}{*}{ ITB 19.1} & $\begin{array}{l}\text { The currencies of the Bid shall be as follows: } \\
\text { (a) The prices shall be quoted either in the currency of the Bidder's home country, or in } \\
\text { any fully convertible currency(ies). } \\
\text { (b) A Bidder expecting to incur a portion of its expenditures in the performance of the } \\
\text { Contract in more than one currency, and wishing to be paid accordingly, shall so } \\
\text { indicate in the Schedule of Prices and the Letter of Bid. }\end{array}$ \\
\hline & $\begin{array}{l}\text { (c) If some of the contract expenditures related to Design, Installation, and Other } \\
\text { Services are to be incurred in the Employer's country, such expenditures shall be } \\
\text { quoted in either foreign and/or local currency, depending upon the currency in } \\
\text { which the costs are to be incurred. }\end{array}$ \\
\hline & $\begin{array}{l}\text { (d) Bidders may be required by the Employer to clarify their local and foreign currency } \\
\text { requirements, and to substantiate that the amounts included in the Price Schedules } \\
\text { are reasonable and responsive to ITB } 18.1 \text { in which case a detailed breakdown of its } \\
\text { foreign currency requirements shall be provided by the Bidder. }\end{array}$ \\
\hline & $\begin{array}{l}\text { (e) During the performance of the contract, the foreign currency portions of the } \\
\text { outstanding balance of the Contract Price may be adjusted by agreement between } \\
\text { the Employer and the Contractor to reflect any changes in foreign currency } \\
\text { requirements for the contract. Any such adjustment shall be effected by comparing } \\
\text { the amounts quoted in the bid with the amounts already used in the Facilities and } \\
\text { the Contractor's future needs for imported items. }\end{array}$ \\
\hline ITB 20.1 & $\begin{array}{l}\text { The bid validity period shall be [insert number of days] days. } \\
\text { [The period should be sufficient to permit completion of evaluation and comparison of bids, review of the } \\
\text { recommended selection by ADB (if so required), acquire all necessary approvals, and notify the successful } \\
\text { bidder of the award. Normally, the bid validity period should not exceed } 120 \text { days.] }\end{array}$ \\
\hline
\end{tabular}




\begin{tabular}{|c|c|}
\hline ITB 21.1 & $\begin{array}{l}\text { [Choose one of the following options as appropriate] } \\
\text { Neither a bid security nor a Bid-Securing Declaration is required. } \\
\text { [or] } \\
\text { The Bidder shall furnish a bid security in the amount of [insert amount and currency. The amount } \\
\text { of the bid security should be stated as a fixed amount, normally computed as } 1 \% \text { to } 2 \% \text { of the estimated } \\
\text { contract value. The amount may be reduced for very large contracts] } \\
\text { [or] } \\
\text { The Bidder shall furnish a Bid-Securing Declaration. }\end{array}$ \\
\hline ITB 21.2 & The ineligibility period will be [insert number of years] \\
\hline ITB 21.4 & $\begin{array}{l}\text { [Choose one of the following options as appropriate.] } \\
\text { No further instruction. } \\
\text { [or] } \\
\text { Subject to the succeeding sentences, any bid not accompanied by an irrevocable and } \\
\text { callable bid security shall be rejected by the Employer as nonresponsive. If a Bidder } \\
\text { submits a bid security that (i) deviates in form, amount, and/or period of validity, or } \\
\text { (ii) does not provide sufficient identification of the Bidder (including, without limitation, } \\
\text { failure to indicate the name of the Joint Venture or, where the Joint Venture has not yet } \\
\text { been constituted, the names of all future Joint Venture Partners), the Employer shall } \\
\text { request the Bidder to submit a compliant bid security within [insert number of days; generally } \\
\text { 14 days] days of receiving such a request. Failure to provide a compliant bid security within } \\
\text { the prescribed period of receiving such a request shall cause the rejection of the Bid. } \\
\text { [or] } \\
\text { Subject to the succeeding sentences, any bid not accompanied by a Bid-Securing } \\
\text { Declaration shall be rejected by the Employer as nonresponsive. If a Bidder submits a } \\
\text { Bid-Securing Declaration that (i) deviates in form, content, and/or period of validity or } \\
\text { (ii) does not provide sufficient identification of the Bidder (including, without limitation, } \\
\text { failure to indicate the name of the Joint Venture or, where the Joint Venture has not yet } \\
\text { been constituted, the names of all future Joint Venture Partners), the Employer shall } \\
\text { request the Bidder to submit a compliant Bid-Securing Declaration within [insert number } \\
\text { of days; generally } 7 \text { days] days of receiving such a request. Failure to provide a compliant } \\
\text { Bid-Securing Declaration within the prescribed period of receiving such a request shall } \\
\text { cause the rejection of the Bid. }\end{array}$ \\
\hline ITB 22.1 & In addition to the original Bid, the number of copies is: [insert number of copies] \\
\hline
\end{tabular}




\begin{tabular}{|l|l|}
\hline ITB 22.2 & $\begin{array}{l}\text { The written confirmation of authorization to sign on behalf of the Bidder shall consist of } \\
\text { [insert the name and description of the documentation required to demonstrate the authority of the signatory } \\
\text { to sign the bid. Employer may wish to consider the following language: "An organizational document, board } \\
\text { resolution or its equivalent, or power of attorney specifying the representative's authority to sign the Bid on } \\
\text { behalf of, and to legally bind, the Bidder. If the Bidder is an intended or an existing Joint Venture, the power } \\
\text { of attorney should be signed by all partners and specify the authority of the named representative of the Joint } \\
\text { Venture to sign on behalf of, and legally bind, the intended or existing Joint Venture. If the Joint Venture has } \\
\text { not yet been formed, also include evidence from all proposed Joint Venture partners of their intent to enter into } \\
\text { a Joint Venture in the event of a contract award in accordance with ITB 11.2."] }\end{array}$ \\
\hline ITB 22.2 & $\begin{array}{l}\text { The Bidder shall submit an acceptable authorization within [insert number of days, generally } \\
\text { 14 days] days. }\end{array}$ \\
\hline
\end{tabular}

\section{Submission and Opening of Bids}

\begin{tabular}{|c|c|}
\hline ITB 23.1 & $\begin{array}{l}\text { [Choose one of the following options as appropriate.] } \\
\text { Bidders shall submit their Bids by mail or by hand. } \\
{[\text { or }]} \\
\text { Bidders shall submit their Bids electronically. }\end{array}$ \\
\hline ITB 23.1(b) & $\begin{array}{l}\text { Electronic bidding submission procedures shall be: [insert a description of the electronic bidding } \\
\text { submission procedures if applied in accordance with ITB } 23.1 \text { above; otherwise, state "not applicable"] }\end{array}$ \\
\hline ITB 24.1 & $\begin{array}{l}\text { For bid submission purposes only, the Employer's address is [Insert details below as appropriate] } \\
\text { Attention: } \\
\text { Street address: } \\
\text { Floor/Room number: } \\
\text { City: } \\
\text { ZIP code: } \\
\text { Country: } \\
\text { The deadline for bid submission is } \\
\text { Date: } \\
\text { Time: }\end{array}$ \\
\hline
\end{tabular}




\begin{tabular}{|l|l|}
\hline ITB 27.1 & The bid opening shall take place at [insert details below as appropriate] \\
& Street address: \\
Floor/Room number: & City: \\
Country: & Date: \\
& Time: \\
\hline ITB 27.1 & $\begin{array}{l}\text { Electronic bid opening procedure shall be as follows: [if electronic bidding is permitted in } \\
\text { accordance with ITB 23.1, insert here a description of the electronic bid opening procedures; otherwise, } \\
\text { state "not applicable"] }\end{array}$ \\
\hline ITB 27.3 & $\begin{array}{l}\text { The Letter of Bid and Price Schedules shall be initialed by [insert number of initials] } \\
\text { representatives of the Employer attending the Bid opening. }\end{array}$ \\
\hline
\end{tabular}

\section{E. Evaluation and Comparison of Bids}

\begin{tabular}{|l|l|}
\hline ITB 34.1 & $\begin{array}{l}\text { The currency that shall be used for bid evaluation and comparison purposes to convert all } \\
\text { bid prices expressed in various currencies into a single currency is: [insert name of currency] }\end{array}$ \\
& $\begin{array}{l}\text { The source of the selling exchange rate shall be: [insert the name of the source of the exchange } \\
\text { rates, which should be the Central Bank in the employer's country or specify another institution that carries } \\
\text { out the function of a central bank] }\end{array}$ \\
& $\begin{array}{l}\text { The date for the selling exchange rate shall be: [specify either any date (day/month/year) not } \\
\text { earlier than } 28 \text { days prior to the deadline for submission of the bids or later than the original date for the expiry } \\
\text { of bid validity] }\end{array}$ \\
\hline ITB 35.1 & $\begin{array}{l}\text { Domestic preference [insert "shall" or "shall not"] apply. } \\
\text { [If domestic preference applies, insert "The application methodology will be as specified in } \\
\text { Section 3 (Evaluation and Qualification Criteria)."] }\end{array}$ \\
\hline
\end{tabular}


[Choose one of the following options as appropriate.]

The qualifications of other firms such as the Bidder's subsidiaries, parent entities, or affiliates, "shall not" be permitted.

$[o r]$

The qualifications of other firms such as the Bidder's subsidiaries, parent entities, or affiliates shall be permitted for criteria 2.3 Financial Situation in Section 3. The other firms must satisfy the criteria stated in 2.1 Eligibility in Section 3.

[or]

The qualifications of other firms such as the Bidder's subsidiaries, parent entities, or affiliates shall be permitted for criterion 2.4.1 Contracts of Similar Size and Nature and/or 2.4.2 Experience in Key Activities in Section 3. The other firms must satisfy the criteria stated in 2.1 Eligibility in Section 3.

[or]

The qualifications of other firms such as the Bidder's subsidiaries, parent entities, or affiliates shall be permitted for criteria 2.3 Financial Situation and 2.4.1 Contracts of Similar Size and Nature and/or 2.4.2 Experience in Key Activities in Section 3. The other firms must satisfy the criteria stated in 2.1 Eligibility in Section 3.

[If permitted, add "The Bidder shall provide the Affiliate Company Guarantee Form included in Section 4 (Bidding Forms) filled out and signed by each subsidiary, parent entity, or affiliate, that the Bidder submits for consideration of the Employer in determining its qualifications."] 


\begin{tabular}{|l|l|}
\hline ITB 40.1 & $\begin{array}{l}\text { Choose one of the following options as appropriate. }] \\
\text { Standstill provisions shall not apply. } \\
\text { Sor }] \\
\text { Standstill provisions shall apply. The duration of standstill period will be [insert number of } \\
\text { days] days from the date of notice of intention for award of contract. } \\
\text { The Employer shall, at the start of the standstill period, notify in writing each bidder } \\
\text { that submitted a bid, of its intention to award a contract to the successful bidder at the } \\
\text { end of standstill period. The notification using the form included in Section } 9 \text { (Contract } \\
\text { Forms) shall include the following information: } \\
\text { (a) the name of each Bidder who submitted a Bid; } \\
\text { (b) the bid prices as read out at bid opening; } \\
\text { (c) the name and evaluated prices of each Bid that was evaluated; } \\
\text { (d) the name of bidders whose bids were rejected and the reasons for their rejection; } \\
\text { (e) the name of the winning Bidder, and the price it offered, as well as the duration and } \\
\text { summary scope of the contract awarded; and } \\
\text { (f) a statement of the reason(s) the bid of the unsuccessful bidder to whom the notification } \\
\text { is addressed was unsuccessful, unless the price information under (e) of this paragraph } \\
\text { already reveals the reason. }\end{array}$ \\
\hline
\end{tabular}

\section{F. Award of Contract}

ITB 45.1

The procedures for Bidding-Related Complaints are referenced in Appendix 7 of the Procurement Regulations for ADB Borrowers. The Bidder should submit its complaint following these procedures, in writing, to:

For the attention: [insert full name of person receiving complaints]

Title/position: [insert title/position]

Employer: [insert name of Employer]

E-mail address: [insert e-mail address]

Fax number: [insert fax number] delete if not used] 


\section{Section 3: Evaluation and Qualification Criteria}

\section{NOTES}

This section contains the criteria that the Employer shall use to evaluate bids and qualify Bidders if the bidding was not preceded by a prequalification exercise and postqualification is applied. ADB requires Bidders to be qualified by meeting predefined, precise minimum requirements. The method entails setting pass-fail criteria, which, if not met by the Bidder, results in disqualification. It will therefore be necessary to ensure that a Bidder's risk of having its bid rejected on grounds of qualification is remote if due diligence is exercised by the Bidder during bid preparation. For that purpose, clear-cut, pass-fail qualification criteria need to be defined and indicated in the Invitation for Bids and the Bidding Document to enable Bidders to make an informed decision whether to pursue a specific contract and, if so, whether to pursue it as a single entity or in Joint Venture. The criteria adopted must relate to characteristics that are essential to ensure satisfactory execution of the contract, and must be stated in clear terms. In accordance with ITB 36 to ITB 38, no other methods, criteria, and factors shall be used. The Bidder shall provide all the information requested in the forms included in Section 4 (Bidding Forms).

In case the bidding was preceded by a prequalification process, updating of information pertaining to a Bidder's eligibility, historical contract nonperformance, and financial situation will be necessary during bidding.

\section{Table of Criteria}

1. Evaluation

1.1 Technical Evaluation .48

1.2 Alternative Technical Solutions. .48

1.3 Economic Evaluation .48

1.4 Multiple Contracts

2. Qualification

2.1 Eligibility

2.1.1 Nationality

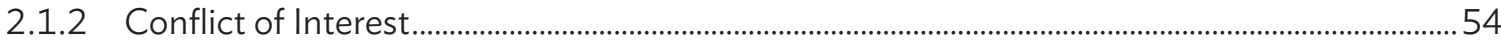

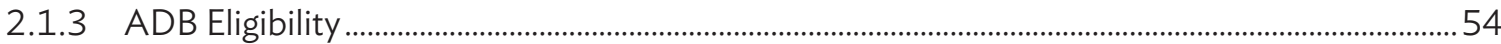

2.1.4 Government-Owned Enterprise .............................................................................................................54

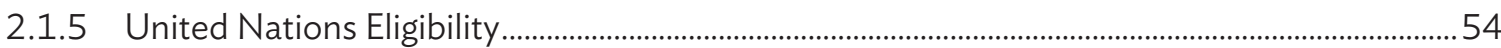

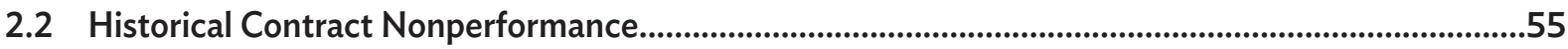

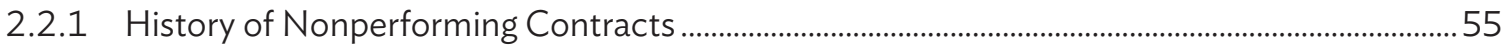

2.2.2 Suspension Based on Execution of Bid-Securing Declaration.....................................................55

2.2.3 Pending Litigation and Arbitration.....................................................................................................56

2.2.4 Declaration: Environmental, Health and Safety Past Performance ..............................................56 


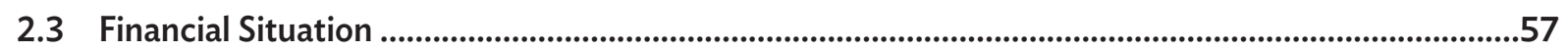

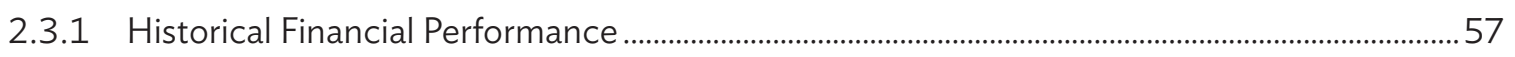

2.3.2 Average Annual Turnover .............................................................................................................. 57

2.3.3 Financial Resources ....................................................................................................................... 58

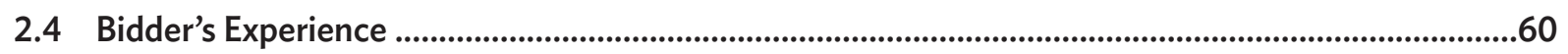

2.4.1 Contracts of Similar Size and Nature

2.4.2 Experience in Key Activities ...............................................................................................................62

2.4.3 Specific Experience in Managing Environmental, Health and Safety Aspects ...........................63

2.5 Organizational Environmental, Health and Safety System ........................................................................ 64

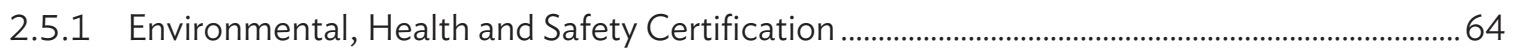

2.5.2 Environmental, Health and Safety Documentation ............................................................................. 65

2.5.3 Environmental, Health and Safety Dedicated Personnel ................................................................65

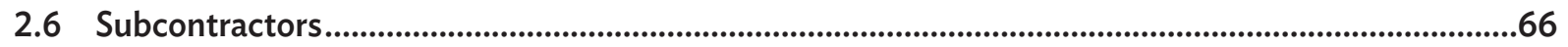




\section{Evaluation}

\subsection{Technical Evaluation}

In addition to the criteria listed in ITB 36.2 (a)-(b), other relevant factors are as follows:

Evaluation of the Bidder's Technical Proposal will include an assessment of the Bidder's technical capacity to successfully implement the contract considering its proposed site organization, method statement, mobilization, and construction schedule (to be described by the Bidder in sufficient detail to demonstrate the adequacy of its work methods, scheduling, and material sourcing) including the extent to which they are presented in a consistent manner and comply with requirements stipulated in Section 6 (Employer's Requirements) without material deviation, reservation, or omission.

Noncompliance with equipment and personnel requirements described in Section 6 (Employer's Requirements) shall not normally be a ground for bid rejection and such noncompliance will be subject to clarification during bid evaluation and rectification prior to contract award.

\section{NOTE}

The Employer shall refer to the appropriate forms in Section 4 to be filled out, if provided. The Employer shall assess whether proposed site organization, method statement, mobilization, construction schedule, plant, proposed Subcontractors for major items of plant and services, and time schedule described in Section 4 (Bidding Forms) are presented in a consistent manner and comply with requirements stipulated in Section 6 (Employer's Requirements) without material deviation, reservation, or omission.

\subsection{Alternative Technical Solutions}

Technical alternatives, if permitted under ITB 13.4, will be evaluated as follows:

\section{NOTE}

The Employer shall describe how this factor will be evaluated.

\subsection{Economic Evaluation}

In addition to the criteria listed in ITB 36.4 I (a)-(f), other relevant factors are as follows:

Adjustments in price that result from the procedures outlined below shall be added, for purposes of comparative evaluation only, to arrive at an "Evaluated Bid Price." Bid prices quoted by Bidders shall remain unaltered.

\subsubsection{Quantifiable Deviations and Omissions}

Quantifiable Deviations and Omissions from the contractual obligations: the evaluation shall be based on the evaluated cost of fulfilling the contract in compliance with all contractual obligations under this Bidding Document. 
[Insert: "Pursuant to ITB 32.3, the cost of all quantifiable nonmaterial nonconformities or omissions from the contractual and commercial conditions shall be evaluated. The Employer will make its own assessment of the cost of any nonmaterial nonconformities and omissions for the purpose of ensuring fair comparison of Bids."]

\section{NOTE}

Subject to ITB 18.1 and ITB 18.2, the cost of minor omissions or missing items should be added to the bid price to allow for bid comparison on an equal basis. The price adjustment should be based on a reasonable estimate of the cost by the executing agency, engineer, consultant, or bid evaluation committee, taking into consideration the corresponding quoted prices from other conforming bids. The price adjustment should be based on the fair price of the omitted item. The most frequently used method is to use the price equal to the highest price quoted for the same item by the other responsive Bidders.

\subsubsection{Time Schedule}

Time to complete the plant and services from the effective date specified in Article 3 of the Contract Agreement for determining the time for completion of precommissioning activities is:

[insert number of days]. No credit will be given for earlier completion.

\section{NOTE}

The completion time specified shall be for the entire plant and services or for parts or sections of the plant and services.

or

Time to complete the plant and services from the effective date specified in Article 3 of the Contract Agreement for determining the time for completion of precommissioning activities shall be between [insert number of days] minimum and [insert number of days] maximum. The adjustment rate in the event of completion beyond the minimum period shall be [insert percentage in words and figures] for each week of delay from that minimum period. No credit will be given for completion earlier than the minimum designated period. Bids offering a completion date beyond the maximum designated period shall be rejected.

\section{NOTE}

One-fifth of a percent (0.2\%) per week is a reasonable figure. Alternatively, the rate may be a fixed amount per month, or pro rata per week, of delay related to the loss of benefits to the Employer. The accepted period between the minimum and maximum time for completion should be such that the percentage or amount corresponding to the maximum period for completion should be less than or equal to the percentage or amount of liquidated damages specified in the Special Conditions of Contract in relation to General Conditions of Contract Subclause 26.2. 


\subsubsection{Operation and Maintenance Costs}

Since the operation and maintenance $(O \& M)$ costs of the facilities being procured form a major part of the life cycle cost of the facilities, these costs will be evaluated according to the principles given hereafter, including the cost of spare parts for the initial period of operation stated below and based on prices furnished by each Bidder in Price Schedule Nos. 1 and 2, as well as on past experience of the Employer or other employers similarly placed. Such costs shall be added to the bid price for evaluation. The price of recommended spare parts quoted in Price Schedule No. 6 shall not be considered for evaluation. Use of unverifiable future $O \& M$ cost and consumption figures as a factor in economic evaluation should be avoided.

\section{NOTE}

Use one of the two options given below.

The O\&M cost factors for calculating the life cycle cost are as follows:

(a) Number of years for life cycle [insert life cycle period in years. The period should not exceed the period before a major overhaul of the facilities becomes necessary]

(b) Operating costs [insert fuel and/or other input, unit cost for annual and total operational requirements]

(c) Maintenance costs, including the cost of spare parts for the initial period of operation

(d) A rate of [insert rate in words and figures] in percentage to be used to discount to present value all annual future costs calculated under (b) and (c) for the period specified in (a)

or

[insert a reference to the methodology specified in the specifications or elsewhere in the Bidding Document]

\subsubsection{Functional Guarantees of the Facilities}

The minimum and/or maximum requirements stated in the Specification for functional guarantees required in the Specification are the following:

[insert appropriate reference to the Functional Guarantees, and use text suggested below]

\begin{tabular}{|l|c|}
\multicolumn{1}{c|}{$\begin{array}{c}\text { Functional Guarantee } \\
\text { [as required in the Specification, e.g., performance, } \\
\text { efficiency, consumption, etc. }]\end{array}$} & $\begin{array}{c}\text { Minimum and/or Maximum Requirements } \\
\text { [as required in the Specification }]\end{array}$ \\
\hline 1. & \\
\hline 2. & \\
\hline 3. & \\
\hline$\ldots$ & \\
\hline
\end{tabular}

For the purposes of evaluation, for each percentage point in performance or efficiency below the norm specified in the Specification but above the minimum acceptable levels also specified there, an adjustment of [insert amount in the currency of bid evaluation] will be added to the bid price. 


\subsubsection{Work, Services, Facilities, etc., to Be Provided by the Employer}

Where bids include the undertaking of work or the provision of services or facilities by the Employer in excess of the provisions allowed for in the Bidding Document, the Employer shall assess the costs of such additional work, services, and/or facilities during the duration of the contract. Such costs shall be added to the bid price for evaluation.

\subsubsection{Specific Additional Criteria}

The following additional criteria will be used in the evaluation:

[if applicable, insert a list of additional criteria or a reference to criteria specified elsewhere in the Bidding Document]

Add any other relevant criteria to consider in bid evaluation, such as quality, responsiveness to socioeconomic or environmental objective, sustainable procurement technical requirements that have been specified in Section 6, special security considerations at the site, and Bidder's records of achieving the desired results based on experience and performance history. For each criterion, clearly specify the evaluation methodology, e.g. (i) any relevant requirement specified in Section 6 will be evaluated on a pass/fail (compliance basis), (ii) in addition to evaluating that requirement on a pass/fail (compliance basis), if applicable, specify the monetary adjustments to be applied to bid prices for comparison purposes on account of bids that exceed the specified minimum requirements, or (iii) if merit point scoring is applied in the evaluation, the criteria will be one of the technical factors.

\subsubsection{Environmental, Health and Safety Management Plan (EHSMP)}

[The following is a sample criteria]

Any bid not accompanied by the EHSMP may be rejected by the Employer as nonresponsive. If a Bidder submits an EHSMP that is not commensurate with the risks and impacts of the proposed works and activities in the bidding document, the Employer shall issue a clarification to request for further information from the Bidder. The Bidder must submit the requested information within [insert number of days, normally 5 working days] days of receiving such a request. Failure to provide a satisfactory response to the request for further information within the prescribed period of receiving such a request may cause the rejection of the Bid.

\section{NOTE}

The Employer should evaluate the responsiveness of the EHSMP to the requirement of the project Environmental Management Plan and other supplementary reference in Section 6, the Employer's country-specific requirement and local regulations on environmental, health and safety, and/or international good practices and outline here as the basis of evaluation. EA should seek support from the Engineer/PMC/H\&S consultant in reviewing the plan if they do not have inhouse expertise. 


\subsubsection{Sustainable Procurement}

Example text: The following sustainable procurement technical requirements will be evaluated on a pass/fail basis. Failure to meet any of the following requirements will result in mandatory rejection of the bid.

[E.g. No diesel plant is proposed for the construction process.]

\section{NOTE}

If specific sustainable procurement technical requirements have been specified in Section 6 (Employer's Requirements), either state that (i) those requirements will be evaluated on a pass/fail (compliance basis) or otherwise (ii) in addition to evaluating those requirements on a pass/fail (compliance basis), if applicable, specify the monetary adjustments to be applied to Bid prices for comparison purposes on account of Bids that exceed the specified minimum sustainable procurement technical requirements.

\subsubsection{Domestic Preference}

Domestic preference will be granted to eligible domestically produced Plant and Equipment in accordance with the following provisions:

(a) The preference margin shall not be applied to the whole facility but only to the eligible domestically produced Plant and Equipment within the contract.

(b) Plant and Mandatory Spare Parts supplied from abroad shall be quoted CIP (Section 4 [Bidding Forms], Schedule No. 1). Plant and Mandatory Spare Parts supplied from within the Employer's country shall be quoted EXW (exworks, ex factory, exwarehouse, ex showroom, or off-the-shelf, as applicable) free of sales and similar taxes (Section 4 [Bidding Forms], Schedule No. 2).

(c) All other cost components for services and works, such as costs for design, local handling, transportation, storage, installation, and commissioning, shall be quoted separately. See Section 4 (Bidding Forms), Schedule No. 3 on Design Services and Schedule No. 4 on Installation and Other Services.

(d) In the comparison of Bids, only the CIP price component of each Bid for the Plant and Equipment offered from outside the Employer's country shall be increased by [insert a percentage not exceeding 15\%].

(e) No domestic preference shall be applied to any of the services or works included in the contract.

(f) Bidders shall not be permitted or required to modify the mix of local and foreign Plant and Equipment after bid opening. 


\subsection{Multiple Contracts}

If works are grouped in multiple contracts and pursuant to ITB 36.6, the Employer will evaluate and compare Bids on the basis of a contract, or a combination of contracts, or as a total of contracts to arrive at the least cost combination for the Employer by taking into account discounts offered by Bidders in case of award of multiple contracts.

If a Bidder as defined in ITB 4.1 submits several successful (lowest evaluated substantially responsive) bids, the evaluation will also include an assessment of the Bidder's capacity to meet the following aggregated requirements as presented in the bid:

- Average annual turnover,

- Financial resources,

- Equipment to be allocated, and

- Personnel to be fielded.

NOTE

The Employer shall refer to the applicable qualification requirement(s) for each contract in Part 2 of this section. 


\section{Qualification}

\subsection{Eligibility}

\begin{tabular}{|c|c|c|c|c|c|}
\hline Criteria & \multicolumn{4}{|c|}{ Compliance Requirements } & Documents \\
\hline & & \multicolumn{3}{|c|}{ Joint Venture } & \multirow[b]{2}{*}{$\begin{array}{l}\text { Submission } \\
\text { Requirements }\end{array}$} \\
\hline Requirement & Single Entity & $\begin{array}{c}\text { All Partners } \\
\text { Combined }\end{array}$ & $\begin{array}{l}\text { Each } \\
\text { Partner }\end{array}$ & $\begin{array}{l}\text { One } \\
\text { Partner }\end{array}$ & \\
\hline
\end{tabular}

\subsubsection{Nationality}

\begin{tabular}{|l|c|c|c|c|c}
\hline $\begin{array}{l}\text { Nationality in accordance } \\
\text { with ITB 4.2. }\end{array}$ & $\begin{array}{c}\text { Must meet } \\
\text { requirement }\end{array}$ & $\begin{array}{c}\text { Must meet } \\
\text { requirement }\end{array}$ & $\begin{array}{c}\text { Must meet } \\
\text { requirement }\end{array}$ & $\begin{array}{c}\text { Not } \\
\text { applicable }\end{array}$ & $\begin{array}{c}\text { Forms ELI - 1; } \\
\text { ELI - 2 with } \\
\text { attachments }\end{array}$ \\
\hline
\end{tabular}

\subsubsection{Conflict of Interest}

No conflicts of interest in accordance with ITB 4.3.
Must meet requirement
Must meet
requirement

Must meet

requirement Not
applicable

Letter of Bid

\subsubsection{ADB Eligibility}

Not having been declared ineligible by ADB, as described in ITB 4.4.

Must meet
requirement

\section{Must meet} requirement
Must meet requirement

\section{Not applicable}

Letter of Bid

\subsubsection{Government-Owned Enterprise}

Bidder required to meet conditions of ITB 4.5.
Must meet

requirement
Must meet requirement
Must meet

requirement
Not applicable
Forms ELI - 1;

ELI - 2 with attachments

\subsubsection{United Nations Eligibility}

\begin{tabular}{|l|c|c|c|c|c|}
\hline $\begin{array}{l}\text { Not having been excluded } \\
\text { by an act of compliance with } \\
\text { a United Nations Security } \\
\text { Council resolution in } \\
\text { accordance with ITB 4.8. }\end{array}$ & $\begin{array}{c}\text { Must meet } \\
\text { requirement }\end{array}$ & $\begin{array}{c}\text { Must meet } \\
\text { requirement }\end{array}$ & $\begin{array}{c}\text { Must meet } \\
\text { requirement }\end{array}$ & $\begin{array}{c}\text { Not } \\
\text { applicable }\end{array}$ & Letter of Bid \\
\hline
\end{tabular}




\section{NOTE}

It is the obligation of the Employer to confirm an entity's eligibility by checking ADB's complete Sanctions List (for all bidders) at various stages of bidding process including bid evaluation, prior to contract award, as well as during processing of contract variations, extensions or modifications. ADB has the right to monitor the Employer's compliance to this obligation.

ADB's complete Sanctions List and the guide on how to get its access are available at https://www.adb.org/who-we-are/ integrity/sanctions

\subsection{Historical Contract Nonperformance}

\subsubsection{History of Nonperforming Contracts}

\begin{tabular}{|c|c|c|c|c|c|}
\hline Criteria & \multicolumn{4}{|c|}{ Compliance Requirements } & Documents \\
\hline \multirow[b]{2}{*}{ Requirement } & \multirow[b]{2}{*}{$\begin{array}{l}\text { Single } \\
\text { Entity }\end{array}$} & \multicolumn{3}{|c|}{ Joint Venture } & \multirow[b]{2}{*}{$\begin{array}{c}\text { Submission } \\
\text { Requirements }\end{array}$} \\
\hline & & $\begin{array}{l}\text { All Partners } \\
\text { Combined }\end{array}$ & $\begin{array}{c}\text { Each } \\
\text { Partner }\end{array}$ & $\begin{array}{c}\text { One } \\
\text { Partner }\end{array}$ & \\
\hline $\begin{array}{l}\text { Nonperformance of a contract }{ }^{\text {a }} \text { did } \\
\text { not occur as a result of contractor } \\
\text { default since } 1 \text { January [insert year]. }\end{array}$ & $\begin{array}{l}\text { Must meet } \\
\text { requirement }\end{array}$ & $\begin{array}{l}\text { Must meet } \\
\text { requirement }\end{array}$ & $\begin{array}{l}\text { Must meet } \\
\text { requirement }\end{array}$ & $\begin{array}{c}\text { Not } \\
\text { applicable }\end{array}$ & Form $\mathrm{CON}-1$ \\
\hline
\end{tabular}

a Nonperformance, as decided by the Employer, shall include all contracts where (a) nonperformance was not challenged by the contractor, including through referral to the dispute resolution mechanism under the respective contract, and (b) contracts that were so challenged but fully settled against the contractor. Nonperformance shall not include contracts where Employers decision was overruled by the dispute resolution mechanism. Nonperformance must be based on all information on fully settled disputes or litigation, i.e. dispute or litigation that has been resolved in accordance with the dispute resolution mechanism under the respective contract and where all appeal instances available to the Bidder have been exhausted.

b This requirement also applies to contracts executed by the Bidder as Joint Venture partner.

\subsubsection{Suspension Based on Execution of Bid-Securing Declaration}

\begin{tabular}{|c|c|c|c|c|c|}
\hline Criteria & \multicolumn{4}{|c|}{ Compliance Requirements } & Documents \\
\hline \multirow[b]{2}{*}{ Requirement } & \multirow[b]{2}{*}{ Single Entity } & \multicolumn{3}{|c|}{ Joint Venture } & \multirow[b]{2}{*}{$\begin{array}{l}\text { Submission } \\
\text { Requirements }\end{array}$} \\
\hline & & $\begin{array}{c}\text { All Partners } \\
\text { Combined }\end{array}$ & $\begin{array}{c}\text { Each } \\
\text { Partner }\end{array}$ & $\begin{array}{c}\text { One } \\
\text { Partner }\end{array}$ & \\
\hline $\begin{array}{l}\text { Not under suspension based } \\
\text { on execution of a Bid-Securing } \\
\text { Declaration pursuant to ITB } 4.6 \text {. }\end{array}$ & $\begin{array}{l}\text { Must meet } \\
\text { requirement }\end{array}$ & $\begin{array}{l}\text { Must meet } \\
\text { requirement }\end{array}$ & $\begin{array}{c}\text { Must meet } \\
\text { requirement }\end{array}$ & $\begin{array}{c}\text { Not } \\
\text { applicable }\end{array}$ & Letter of Bid \\
\hline
\end{tabular}




\subsubsection{Pending Litigation and Arbitration}

Pending litigation and arbitration criterion [shall/shall not] apply. ${ }^{a}$

\begin{tabular}{|c|c|c|c|c|c|}
\hline Criteria & \multicolumn{4}{|c|}{ Compliance Requirements } & Documents \\
\hline \multirow[b]{2}{*}{ Requirement } & \multirow[b]{2}{*}{ Single Entity } & \multicolumn{3}{|c|}{ Joint Venture } & \multirow[b]{2}{*}{$\begin{array}{l}\text { Submission } \\
\text { Requirements }\end{array}$} \\
\hline & & $\begin{array}{c}\text { All Partners } \\
\text { Combined }\end{array}$ & $\begin{array}{c}\text { Each } \\
\text { Partner }\end{array}$ & $\begin{array}{c}\text { One } \\
\text { Partner }\end{array}$ & \\
\hline $\begin{array}{l}\text { All pending litigation, arbitration or } \\
\text { other material events impacting the net } \\
\text { worth and/or liquidity of the bidder, if } \\
\text { any, shall be treated as resolved against } \\
\text { the Bidder and so shall in total not } \\
\text { represent more than ............... } \\
\ldots . \text { bercent of the Bidder's net worth } \\
\text { calculated as the difference between } \\
\text { total assets and total liabilities. }\end{array}$ & $\begin{array}{l}\text { Must meet } \\
\text { requirement }\end{array}$ & $\begin{array}{c}\text { Not } \\
\text { applicable }\end{array}$ & $\begin{array}{l}\text { Must meet } \\
\text { requirement }\end{array}$ & $\begin{array}{c}\text { Not } \\
\text { applicable }\end{array}$ & Form CON - 1 \\
\hline
\end{tabular}

a The Employer may choose whether to apply or not to apply this criterion:

1 If the Employer chooses to apply this criterion, it should indicate "shall apply" and use the table in 2.2.3, or

2 If the Employer chooses not to apply this criterion, it should indicate "shall not apply" and delete the table in 2.2.3.

b If the criterion is applied, the Employer should indicate a percentage within the range of $50 \%-100 \%$ of a Bidder's net worth.

\subsubsection{Declaration: Environmental, Health and Safety Past Performance}

\begin{tabular}{|c|c|c|c|c|c|}
\hline Criteria & \multicolumn{4}{|c|}{ Compliance Requirements } & Documents \\
\hline Requirement & Single Entity & $\begin{array}{c}\text { All Partners } \\
\text { Combined }\end{array}$ & $\begin{array}{c}\text { Each } \\
\text { Partner }\end{array}$ & $\begin{array}{c}\text { One } \\
\text { Partner }\end{array}$ & $\begin{array}{l}\text { Submission } \\
\text { Requirements }\end{array}$ \\
\hline $\begin{array}{l}\text { Declare any contracts } \\
\text { that have been suspended } \\
\text { or terminated and/or } \\
\text { performance security called by } \\
\text { an employer for reasons related } \\
\text { to the noncompliance of any } \\
\text { environmental, health and } \\
\text { safety contractual obligations } \\
\text { in the past five years. }^{\text {a }}\end{array}$ & $\begin{array}{l}\text { Must make the } \\
\text { declaration. } \\
\text { If the bidder } \\
\text { proposes } \\
\text { Specialist } \\
\text { Subcontractor/s } \\
\text { to meet EQC } \\
\text { 2.4.2, those } \\
\text { Specialist } \\
\text { Subcontractor/s } \\
\text { must also make } \\
\text { the declaration }\end{array}$ & $\begin{array}{c}\text { Not } \\
\text { applicable }\end{array}$ & $\begin{array}{l}\text { Each partner } \\
\text { must make the } \\
\text { declaration. } \\
\text { If the bidder } \\
\text { proposes } \\
\text { Specialist } \\
\text { Subcontractor/s } \\
\text { to meet EQC } \\
2.4 .2 \text {, those } \\
\text { Specialist } \\
\text { Subcontractor/s } \\
\text { must also make } \\
\text { the declaration. }\end{array}$ & $\begin{array}{c}\text { Not } \\
\text { applicable }\end{array}$ & Form $\mathrm{CON}-2$ \\
\hline
\end{tabular}

a The Employer may use this information to seek further information or clarifications regarding corrective actions undertaken by the contractor during the bidding stage and the associated due diligence. 


\subsection{Financial Situation}

\subsubsection{Historical Financial Performance}

\begin{tabular}{|c|c|c|c|c|c|}
\hline Criteria & \multicolumn{4}{|c|}{ Compliance Requirements } & Documents \\
\hline \multirow[b]{2}{*}{ Requirement } & \multirow[b]{2}{*}{ Single Entity } & \multicolumn{3}{|c|}{ Joint Venture } & \multirow[b]{2}{*}{$\begin{array}{l}\text { Submission } \\
\text { Requirements }\end{array}$} \\
\hline & & $\begin{array}{c}\text { All Partners } \\
\text { Combined }\end{array}$ & $\begin{array}{c}\text { Each } \\
\text { Partner }\end{array}$ & $\begin{array}{c}\text { One } \\
\text { Partner }\end{array}$ & \\
\hline $\begin{array}{l}\text { Submission of audited financial } \\
\text { statements or, if not required by the } \\
\text { law of the Bidder's country, other } \\
\text { financial statements acceptable to } \\
\text { the Employer, for the last ... a years to } \\
\text { demonstrate the current soundness } \\
\text { of the Bidder's financial position. As } \\
\text { a minimum, the Bidder's net worth } \\
\text { for the last year calculated as the } \\
\text { difference between total assets and } \\
\text { total liabilities should be positive. }\end{array}$ & $\begin{array}{l}\text { Must meet } \\
\text { requirement }\end{array}$ & $\begin{array}{c}\text { Not } \\
\text { applicable }\end{array}$ & $\begin{array}{l}\text { Must meet } \\
\text { requirement }\end{array}$ & $\begin{array}{c}\text { Not } \\
\text { applicable }\end{array}$ & $\begin{array}{c}\text { Form FIN - } 1 \\
\text { with } \\
\text { attachments }\end{array}$ \\
\hline
\end{tabular}

a Indicate time period between 3 and 5 years.

\section{Note}

The financial information provided by the Bidder should be reviewed in its entirety to allow a truly informed judgment, and the pass-fail decision on the financial position of the Bidder should be given on this basis. Any abnormal features that may lead to financial problems should alert the Employer to seek expert professional advice for further review and interpretation.

\subsubsection{Average Annual Turnover}

\begin{tabular}{|c|c|c|c|c|c|}
\hline Criteria & \multicolumn{4}{|c|}{ Compliance Requirements } & Documents \\
\hline \multirow[b]{2}{*}{ Requirement } & \multirow[b]{2}{*}{ Single Entity } & \multicolumn{3}{|c|}{ Joint Venture } & \multirow[b]{2}{*}{$\begin{array}{l}\text { Submission } \\
\text { Requirements }\end{array}$} \\
\hline & & $\begin{array}{l}\text { All Partners } \\
\text { Combined }\end{array}$ & $\begin{array}{c}\text { Each } \\
\text { Partner }\end{array}$ & $\begin{array}{c}\text { One } \\
\text { Partner }\end{array}$ & \\
\hline $\begin{array}{l}\text { Minimum average annual turnover } \\
\text { of } \$ \ldots \ldots \ldots{ }^{\text {a }} \text { calculated as total } \\
\text { certified payments received for } \\
\text { contracts in progress or completed, } \\
\text { within the last } \ldots \ldots \text {. }^{\text {years. }}\end{array}$ & $\begin{array}{l}\text { Must meet } \\
\text { requirement }\end{array}$ & $\begin{array}{l}\text { Must meet } \\
\text { requirement }\end{array}$ & $\begin{array}{l}\text { Must meet } \\
\ldots \ldots \ldots{ }^{c} \\
\text { of the } \\
\text { requirement }\end{array}$ & $\begin{array}{l}\text { Must meet } \\
\ldots \ldots \ldots{ }^{d} \\
\text { of the } \\
\text { requirement }\end{array}$ & Form FIN - 2 \\
\hline
\end{tabular}

a The amount stated should normally not be less than two times the annualized value of the subject contract, expressed as $2 \times \mathrm{V} / \mathrm{T}$; where $\mathrm{V}$ is the Employer's estimated cost (including contingencies), $\mathrm{T}$ is the contract duration in years. For contract duration of up to one (1) year, T of "1" should be used. The multiplier of 2 may be reduced for very large contracts but should not be less than 1.5.

b Insert number of years in words and figures and indicate time period between 3 and 5 years.

c The Employer is to define this value based on the minimum amount required that all partners of the Joint Venture must meet taking joint and several liability into account, usually at least $25 \%$.

$d$ The Employer is to define this value based on the minimum amount required that one partner of the Joint Venture must meet, usually at least $40 \%$. 


\subsubsection{Financial Resources ${ }^{2}$}

If the bid evaluation process and the decision for the award of the Contract takes more than 1 year from the date of bid submission, Bidders may be asked to resubmit their current contract commitments and latest information on financial resources supported by latest audited accounts or audited financial statements, or if not required by the law of the Bidder's country, other financial statements acceptable to the Employer, and the Bidders' financial capacity will be reassessed on this basis.

\begin{tabular}{|c|c|c|c|c|c|}
\hline Criteria & \multicolumn{4}{|c|}{ Compliance Requirements } & Documents \\
\hline \multirow[b]{2}{*}{ Requirement } & \multirow[b]{2}{*}{$\begin{array}{l}\text { Single } \\
\text { Entity }\end{array}$} & \multicolumn{3}{|c|}{ Joint Venture } & \multirow[b]{2}{*}{$\begin{array}{l}\text { Submission } \\
\text { Requirements }\end{array}$} \\
\hline & & $\begin{array}{c}\text { All Partners } \\
\text { Combined }\end{array}$ & $\begin{array}{c}\text { Each } \\
\text { Partner }\end{array}$ & $\begin{array}{c}\text { One } \\
\text { Partner }\end{array}$ & \\
\hline $\begin{array}{l}\text { For Single Entities: } \\
\text { The Bidder must demonstrate that its } \\
\text { financial resources defined in Form } \\
\text { FIN - 3, less its financial obligations } \\
\text { for its current contract commitments } \\
\text { defined in Form FIN - 4, meet or } \\
\text { exceed the total requirement for the } \\
\text { Subject Contract of .............. }{ }^{a}\end{array}$ & $\begin{array}{l}\text { Must meet } \\
\text { requirement }\end{array}$ & $\begin{array}{c}\text { Not } \\
\text { applicable }\end{array}$ & $\begin{array}{c}\text { Not } \\
\text { applicable }\end{array}$ & $\begin{array}{c}\text { Not } \\
\text { applicable }\end{array}$ & $\begin{array}{c}\text { Form FIN - } 3 \\
\text { and } \\
\text { Form FIN }-4\end{array}$ \\
\hline $\begin{array}{l}\text { For Joint Ventures: } \\
\text { (i) One partner must demonstrate } \\
\text { that its financial resources defined } \\
\text { in Form FIN }-3 \text {, less its financial } \\
\text { obligations for its own current } \\
\text { contract commitments defined } \\
\text { in Form FIN }-4 \text {, meet or exceed } \\
\text { its required share of .............. } \\
\text { from the total requirement for the } \\
\text { Subject Contract. }\end{array}$ & $\begin{array}{c}\text { Not } \\
\text { applicable }\end{array}$ & $\begin{array}{c}\text { Not } \\
\text { applicable }\end{array}$ & $\begin{array}{c}\text { Not } \\
\text { applicable }\end{array}$ & $\begin{array}{l}\text { Must meet } \\
\text { requirement }\end{array}$ & $\begin{array}{c}\text { Form FIN - } 3 \\
\text { and } \\
\text { Form FIN - } 4\end{array}$ \\
\hline AND & & & & & \\
\hline
\end{tabular}

2 The employer has the option to move this criterion from Section 3 (Evaluation and Qualification Criteria) to Section 6 (Employer's Requirements), in which case:

(a) the employer shall confirm compliance with the financial resources criterion prior to award of contract in accordance with ITB 41.1 Award Criteria; and

(b) in place of the Financial Resources criterion, the employer may require the bidder to submit together with its bid, and for confirmation during bid evaluation, a Letter of Undertaking to comply with the financial resources given in Section 6 prior to award of contract. 


\begin{tabular}{|c|c|c|c|c|c|}
\hline Criteria & \multicolumn{4}{|c|}{ Compliance Requirements } & Documents \\
\hline \multirow[b]{2}{*}{ Requirement } & \multirow[b]{2}{*}{$\begin{array}{l}\text { Single } \\
\text { Entity }\end{array}$} & \multicolumn{3}{|c|}{ Joint Venture } & \multirow[b]{2}{*}{$\begin{array}{c}\text { Submission } \\
\text { Requirements }\end{array}$} \\
\hline & & $\begin{array}{l}\text { All Partners } \\
\text { Combined }\end{array}$ & $\begin{array}{c}\text { Each } \\
\text { Partner }\end{array}$ & $\begin{array}{c}\text { One } \\
\text { Partner }\end{array}$ & \\
\hline $\begin{array}{l}\text { (ii) Each partner must demonstrate } \\
\text { that its financial resources defined } \\
\text { in Form FIN - 3, less its financial } \\
\text { obligations for its own current } \\
\text { contract commitments defined } \\
\text { in Form FIN - } 4 \text {, meet or exceed } \\
\text { its required share of .............. }{ }^{c} \\
\text { from the total requirement for the } \\
\text { Subject Contract. } \\
\text { AND }\end{array}$ & $\begin{array}{c}\text { Not } \\
\text { applicable }\end{array}$ & $\begin{array}{c}\text { Not } \\
\text { applicable }\end{array}$ & $\begin{array}{l}\text { Must meet } \\
\text { requirement }\end{array}$ & $\begin{array}{c}\text { Not } \\
\text { applicable }\end{array}$ & $\begin{array}{c}\text { Form FIN }-3 \text { and } \\
\text { Form FIN }-4\end{array}$ \\
\hline $\begin{array}{l}\text { (iii) The Joint Venture must } \\
\text { demonstrate that the combined } \\
\text { financial resources of all partners } \\
\text { defined in Form FIN - } 3 \text {, less } \\
\text { all the partners' total financial } \\
\text { obligations for the current } \\
\text { contract commitments defined in } \\
\text { Form FIN - } 4 \text {, meet or exceed the } \\
\text { total requirement for the Subject } \\
\text { Contract of ............. }\end{array}$ & $\begin{array}{c}\text { Not } \\
\text { applicable }\end{array}$ & $\begin{array}{l}\text { Must meet } \\
\text { requirement }\end{array}$ & $\begin{array}{c}\text { Not } \\
\text { applicable }\end{array}$ & $\begin{array}{c}\text { Not } \\
\text { applicable }\end{array}$ & $\begin{array}{c}\text { Form FIN }-3 \text { and } \\
\text { Form FIN }-4\end{array}$ \\
\hline
\end{tabular}

a The Employer is to specify the total requirement for the Subject Contract based on the following calculation: 3 (or 4) x Estimated Contract Value (Inclusive of Taxes and Duties)

Completion Period in Months

b The Employer is to define this value based on the minimum amount one partner of the Joint Venture must meet, usually at least $40 \%$ of the total requirement for the Subject Contract. This value is to be carried forward to Form FIN - 5B when it is used.

c The Employer is to define this value based on the minimum amount each partner of the Joint Venture must meet, usually at least $25 \%$ of the total requirement for the Subject Contract. This value is to be carried forward to Form FIN - 5B when it is used.

\section{NOTE}

Form FIN - 5 is made available for use by the Bidder as a self-assessment tool, and by the Employer as an evaluation work sheet, to determine compliance with the financial resources requirement as stated in 2.3.3. Failure to submit Form FIN - 5 by the Bidder shall not lead to bid rejection. 


\subsection{Bidder's Experience}

\subsubsection{Contracts of Similar Size and Nature ${ }^{3}$}

\begin{tabular}{|c|c|c|c|c|c|}
\hline Criteria & \multicolumn{4}{|c|}{ Compliance Requirements } & Documents \\
\hline \multirow[b]{2}{*}{ Requirement } & \multirow[b]{2}{*}{$\begin{array}{l}\text { Single } \\
\text { Entity }\end{array}$} & \multicolumn{3}{|c|}{ Joint Venture } & \multirow[b]{2}{*}{$\begin{array}{l}\text { Submission } \\
\text { Requirements }\end{array}$} \\
\hline & & $\begin{array}{c}\text { All Partners } \\
\text { Combined }\end{array}$ & $\begin{array}{c}\text { Each } \\
\text { Partner }\end{array}$ & $\begin{array}{c}\text { One } \\
\text { Partner }\end{array}$ & \\
\hline $\begin{array}{l}\text { Participation as a contractor, } \\
\text { Joint Venture partner, or } \\
\text { Subcontractor, in at least } \\
\text { one contract that has been } \\
\text { satisfactorily and substantially } \\
\text { completed within the last ... } \\
. . \text { b years and that is similar to } \\
\text { the proposed contract, where } \\
\text { the value of the Bidder's } \\
\text { participation exceeds } \$ \ldots . . . \\
\text { The similarity of the Bidder's } \\
\text { participation shall be based } \\
\text { on: d, e, f } \\
\text { 1..... } \\
\text { 2..... } \\
\text { 3..... }\end{array}$ & $\begin{array}{l}\text { Must meet } \\
\text { requiremen }\end{array}$ & $\begin{array}{c}\text { Not } \\
\text { applicable }\end{array}$ & $\begin{array}{c}\text { Not } \\
\text { applicable }\end{array}$ & $\begin{array}{l}\text { Must meet } \\
\text { requirement }\end{array}$ & Form EXP $-1^{\mathrm{h}}$ \\
\hline
\end{tabular}

Or

3 The Employer has the option of requiring either one or two contracts of similar size and nature and should choose the appropriate language for the table in 2.4.1. 


\begin{tabular}{|c|c|c|c|c|c|}
\hline Criteria & \multicolumn{4}{|c|}{ Compliance Requirements } & Documents \\
\hline \multirow[b]{2}{*}{ Requirement } & \multirow[b]{2}{*}{$\begin{array}{l}\text { Single } \\
\text { Entity }\end{array}$} & \multicolumn{3}{|c|}{ Joint Venture } & \multirow[b]{2}{*}{$\begin{array}{l}\text { Submission } \\
\text { Requirements }\end{array}$} \\
\hline & & $\begin{array}{c}\text { All Partners } \\
\text { Combined }\end{array}$ & $\begin{array}{c}\text { Each } \\
\text { Partner }\end{array}$ & $\begin{array}{c}\text { One } \\
\text { Partner }\end{array}$ & \\
\hline $\begin{array}{l}\text { Participation as a contractor, } \\
\text { Joint Venture partner, or } \\
\text { Subcontractor, in at least } \\
\text { two contracts that have } \\
\text { been satisfactorily and } \\
\text { substantially completed } \\
\text { within the last .... . b years } \\
\text { and that are similar to the } \\
\text { proposed contract, where } \\
\text { the value of the Bidder's } \\
\text { participation under each } \\
\text { contract exceeds } \$ . . . . \\
\text { The similarity of the Bidder's } \\
\text { participation shall be based } \\
\text { on: d, e,f } \\
\text { 1..... } \\
\text { 2..... } \\
\text { 3..... }\end{array}$ & $\begin{array}{l}\text { Must meet } \\
\text { requirements }\end{array}$ & $\begin{array}{l}\text { Must meet } \\
\text { requirement as } \\
\text { follows: } \\
\text { (i) Either one } \\
\text { partner must meet } \\
\text { requirement } \\
\text { Or } \\
\text { (ii) any two } \\
\text { partners must each } \\
\text { demonstrate one } \\
\text { (1) satisfactorily } \\
\text { and substantially } \\
\text { completed contract } \\
\text { of similar size and } \\
\text { nature }\end{array}$ & $\begin{array}{c}\text { Not } \\
\text { applicableg }\end{array}$ & $\begin{array}{c}\text { Not } \\
\text { applicable }\end{array}$ & Form EXP $-1^{h}$ \\
\hline
\end{tabular}

a The requirement of "substantially completed contract" may vary from bid package to bid package. The requirement of "substantially completed contract" should be carefully reflected in the documents required to be submitted by bidders, to avoid potential issues in bid evaluation (refer Note "h" below). For further guidance on substantial completion of contracts, refer to ADB's Guidance Note on Procurement: Open Competitive Bidding.

b Insert number of years in words and figures. The range is normally $5-10$ years.

c Usually $80 \%$ of the estimated value of the subject contract. In case of repetitive and contiguous works (e.g., transmission lines, water pipeline), the Employer has the option of specifying a value that is between $50 \%$ and $80 \%$ of the subject contract value. If the contract value is not in the specific currency, the exchange rate to be used to calculate the value of the contract shall be the selling rate of the Borrower's Central bank on the date of the contract.

d Specify major requirements in terms of any of the following: physical size, nature of works, complexity, methods, technology, or other characteristics.

e For contracts under which the Bidder participated as a Joint Venture partner or Subcontractor, only the Bidder's share, by value, shall be considered to meet this requirement.

f For contracts implemented by a Joint Venture contractor, if the Bidder comprises the same Joint Venture, the 'Single Entity' requirements will apply.

g In case of complex works, the Employer may require each partner to demonstrate one satisfactorily and substantially completed contract of similar nature where such partner's value of participation exceeds $25 \%$ of the subject contract value.

$\mathrm{h}$ In addition to the submission requirement Form EXP - 1, the bidder shall provide the following supporting documents:

[If the Employer will consider a "substantially completed contract" as one in which the works have been completed, insert the following text:

1. Signed Contract Agreement, and

2. Taking-Over Certificate, Contract Completion Certificate or Performance Certificate,

in sufficient detail to verify the contract name, value and completion time (or substantial completion). If the documents are other than in English, an accurate certified translation of these documents in English shall be provided.]

[If the Employer will consider a "substantially completed contract" as one in which the Contractor has completed all its obligations under the contract, insert the following text:

1. Signed Contract Agreement, and

2. Contract Completion Certificate or Performance Certificate,

in sufficient detail to verify the contract name, value and completion time. If the documents are other than in English, an accurate certified translation of these documents in English shall be provided.] 


\subsubsection{Experience in Key Activities ${ }^{4}$}

2.4.2(a) Must be complied with by the Bidder. In case of a Joint Venture Bidder, the Bidder or at least one of the partners must meet the requirement in the key activity. For contracts under which the Bidder participated as a Joint Venture partner, only the Bidder's designated scope of works under the contracts shall be considered to meet this requirement.

Table A

\begin{tabular}{|l|c|c|c|}
\hline \multicolumn{1}{|c|}{ Criteria } & \multicolumn{2}{c|}{ Compliance Requirements } & Documents \\
\hline \multicolumn{1}{|c|}{ Requirement } & Single Entity & Joint Venture & $\begin{array}{c}\text { Submission } \\
\text { Requirements }\end{array}$ \\
\hline $\begin{array}{l}\text { For the above or other contracts } \\
\text { executed during the period } \\
\text { stipulated in 2.4.1, a minimum } \\
\text { experience in the following key } \\
\text { activities: }\end{array}$ & Must meet requirement & Must meet requirement & Form EXP - 2 \\
\hline $1 \ldots \ldots .$. & & & \\
\hline $2 \ldots \ldots . .$. & & & \\
\hline $3 \ldots$ etc .... & & & \\
\hline
\end{tabular}

a Under Criterion 2.4.1, the specified requirements define the similarity of contracts, whereas the key activities or production rates to be specified under Criterion 2.4.2 define the required capability of the Bidder to execute key components of the works. There shall be no inconsistency or duplication of requirements between Criteria 2.4.1 and 2.4.2. For the rate of production, specify that the rate of production shall be on the basis of the average during the entire specified period.

b Submission requirements: Form EXP - 2 shall be supported by documents such as Signed Contract Agreement, Taking-Over Certificate or Contract Completion Certificate indicating the contract name, value. completion date (or percentage of substantial completion), activities performed by Joint Venture partners, and other relevant details sufficient to demonstrate compliance with the requirements.

2.4.2(b) The Employer accepts any of the following activities to be subcontracted. They may be complied with by the Bidder or by its proposed Specialist Subcontractor.

If the key activity is to be undertaken by a Specialist Subcontractor, the Employer shall require evidence of the subcontracting agreement from the Bidder.

$4 \quad$ Key activities criterion should confirm Bidder's experience in performing highly specialized activities such as design, installation, testing, commissioning, etc. There shall not be any inconsistency or repetition of requirements between 2.4.1 and 2.4.2. 
Table B

\begin{tabular}{|c|c|c|c|}
\hline Criteria & \multicolumn{2}{|c|}{ Compliance Requirements } & Documents \\
\hline Requirement & $\begin{array}{c}\text { Single Entity or Its } \\
\text { Specialist Subcontractors }\end{array}$ & $\begin{array}{c}\text { Joint Venture or Its } \\
\text { Specialist Subcontractors }\end{array}$ & $\begin{array}{l}\text { Submission } \\
\text { Requirements }\end{array}$ \\
\hline $\begin{array}{l}\text { For the above or other contracts } \\
\text { executed during the period } \\
\text { stipulated in } 2.4 .1 \text {, a minimum } \\
\text { experience in the following key } \\
\text { activities: }{ }^{\text {a, b }}\end{array}$ & $\begin{array}{l}\text { One must meet } \\
\text { requirement }\end{array}$ & $\begin{array}{l}\text { One must meet } \\
\text { requirement }\end{array}$ & Form EXP $-2^{c}$ \\
\hline $4 \ldots \ldots \ldots$ & & & \\
\hline $5 \ldots \ldots \ldots$ & & & \\
\hline 6 .. etc .... & & & \\
\hline
\end{tabular}

a Under Criterion 2.4.1, the specified requirements define the similarity of contracts, whereas the key activities or production rates to be specified under Criterion 2.4.2 define the required capability of the Bidder to execute key components of the works. There shall be no inconsistency or duplication of requirements between Criteria 2.4.1 and 2.4.2. For the rate of production, specify that the rate of production shall be on the basis of the average during the entire specified period.

b The compliance requirement for each key activity that may be met by a specialist subcontractor must define whether the requirement can only be met by a single specialist subcontractor or whether two or more specialist subcontractors can jointly meet the requirement.

c Submission requirements: Form EXP - 2 shall be supported by documents such as Signed Contract Agreement, Taking-Over Certificate or Contract Completion Certificate indicating the contract name, value, completion date (or percentage of substantial completion), activities performed by Joint Venture partners, and other relevant details sufficient to demonstrate compliance with the requirements.

\subsubsection{Specific Experience in managing Environmental, Health and Safety Aspects}

\begin{tabular}{|l|c|c|c|}
\hline \multicolumn{1}{|c|}{ Criteria } & \multicolumn{1}{c|}{ Compliance Requirements } & Documents \\
\hline \multicolumn{1}{|c|}{ Requirement } & $\begin{array}{c}\text { Single Entity or Its } \\
\text { Specialist Subcontractors }\end{array}$ & $\begin{array}{c}\text { Joint Venture or Its } \\
\text { Specialist Subcontractors }\end{array}$ & $\begin{array}{c}\text { Submission } \\
\text { Requirements }\end{array}$ \\
\hline $\begin{array}{l}\text { For the contracts in 2.4.1 and } \\
2.4 .2 \text { above and/or any other } \\
\text { contracts [substantially completed } \\
\text { and under implementation] as } \\
\text { prime contractor, Joint Venture } \\
\text { partner, or Subcontractor } \\
\text { between 1st January ....... and Bid } \\
\text { submission deadline, experience in } \\
\text { managing EHS risks and impacts in } \\
\text { the following aspects: }\end{array}$ & Must meet requirements & $\begin{array}{c}\text { One member must meet } \\
\text { requirements }\end{array}$ & Form EXP - 3 \\
\hline
\end{tabular}

\footnotetext{
a Insert year.
}

b Based on the EHS assessment, specify, as appropriate, specific experience requirements to manage EHS aspects. 


\subsection{Organizational Environmental, Health and Safety System}

\subsubsection{Environmental, Health and Safety Certification}

\begin{tabular}{|c|c|c|c|}
\hline Criteria & \multicolumn{2}{|c|}{ Compliance Requirements } & Documents \\
\hline Requirement & $\begin{array}{c}\text { Single Entity or Its } \\
\text { Specialist Subcontractors }\end{array}$ & $\begin{array}{c}\text { Joint Venture or Its } \\
\text { Specialist Subcontractors }\end{array}$ & $\begin{array}{c}\text { Submission } \\
\text { Requirements }\end{array}$ \\
\hline $\begin{array}{l}\text { Availability of a valid ISO } \\
\text { certification or internationally } \\
\text { recognized equivalent (equivalency } \\
\text { to be demonstrated by the Bidder), } \\
\text { and applicable to the worksite: } \text {, b }^{\text {b }}\end{array}$ & Must meet requirements & $\begin{array}{l}\text { One member must } \\
\text { meet requirements } \\
\text { or } \\
\text { All members must meet } \\
\text { requirements }\end{array}$ & Form EXP - 4 \\
\hline $1 \ldots \ldots \ldots$ & & & \\
\hline $2 \ldots \ldots \ldots$ & & & \\
\hline $3 \ldots \ldots \ldots$ & & & \\
\hline
\end{tabular}

a Examples of certification that can be selected:

1 Quality management certificate ISO 9001

2 Environmental management certificate ISO 14001

3 Health and Safety management certificate ISO 45001

b According to the environmental, health and safety issues of the worksite and the type of competition planned (national or international), it can be decided to not to keep this criterion or only to ask for part of the certifications, specifically the one(s) corresponding to the main issue of the worksite management. 
2.5.2 Environmental, Health and Safety Documentation

\begin{tabular}{|c|c|c|c|}
\hline Criteria & \multicolumn{2}{|c|}{ Compliance Requirements } & Documents \\
\hline Requirement & $\begin{array}{c}\text { Single Entity or Its } \\
\text { Specialist Subcontractors }\end{array}$ & $\begin{array}{l}\text { Joint Venture or Its } \\
\text { Specialist Subcontractors }\end{array}$ & $\begin{array}{l}\text { Submission } \\
\text { Requirement }\end{array}$ \\
\hline $\begin{array}{l}\text { Availability of in-house policies and } \\
\text { procedures for EHS management: } \\
\text { For example: } \\
\text { 1. Existence of an Ethics Charter. } \\
\text { 2. Existence of a system for } \\
\text { monitoring compliance with EHS } \\
\text { commitments for the Bidder's } \\
\text { Subcontractors and all its partners. } \\
\text { 3. Existence of official company } \\
\text { procedures for the management of } \\
\text { the following: } \\
-\quad \ldots \ldots \ldots . \\
-\ldots \ldots . . . \\
-\quad \ldots . . . . . \\
-\end{array}$ & Must meet requirements & $\begin{array}{l}\text { One member must meet } \\
\text { requirements } \\
\text { or } \\
\text { All members must meet } \\
\text { requirements }\end{array}$ & Form EXP - 5 \\
\hline
\end{tabular}

a From the below options, the Employer to select 3-5 that apply to the worksite. The selection should be based on the most pressing EHS issues pertaining to the worksite as detailed in the project EMP.

- EHS resources and facilities and EHS monitoring system;

- Project Areas management information (base camps, quarries, burrow pits, storage areas);

- Health and Safety on worksites policy and related guidance;

- Local recruitment and EHS trainings of local staff/subcontractors/local partners;

- Community stakeholder engagement practice;

- Traffic management practice;

- Hazardous products management practice;

- Waste management practice;

- Protection of water resources;

- Biodiversity protection practices;

- Site rehabilitation and revegetation practice;

- Local cultural heritage protection practice;

- Erosion and sedimentation practices;

- Control of infectious and communicable diseases (HIV/AIDS, malaria, COVID-19 etc)

\subsubsection{Environmental, Health and Safety Dedicated Personnel}

\begin{tabular}{|c|c|c|c|}
\hline Criteria & \multicolumn{2}{|c|}{ Compliance Requirements } & Documents \\
\hline Requirement & $\begin{array}{l}\text { Single Entity or its } \\
\text { Specialist Subcontractors }\end{array}$ & $\begin{array}{l}\text { Joint Venture or its } \\
\text { Specialist Subcontractors }\end{array}$ & $\begin{array}{c}\text { Submission } \\
\text { Requirements }\end{array}$ \\
\hline $\begin{array}{l}\text { Availability of in-house personnel } \\
\text { dedicated to EHS issues: } \\
\text { - Environmental Specialist } \\
\text { - Health and Safety Specialist }\end{array}$ & Must meet requirement & $\begin{array}{l}\text { One member must meet } \\
\text { requirements } \\
\text { or } \\
\text { All members must meet } \\
\text { requirements }\end{array}$ & Form EXP - 6 \\
\hline
\end{tabular}




\subsection{Subcontractors}

Subcontractors or Manufacturers for the following major items of plant and services must meet the following minimum qualification criteria, herein listed for a Subcontractor for that item. Failure to comply with this requirement will result in rejection of the Subcontractor but not the Bidder.

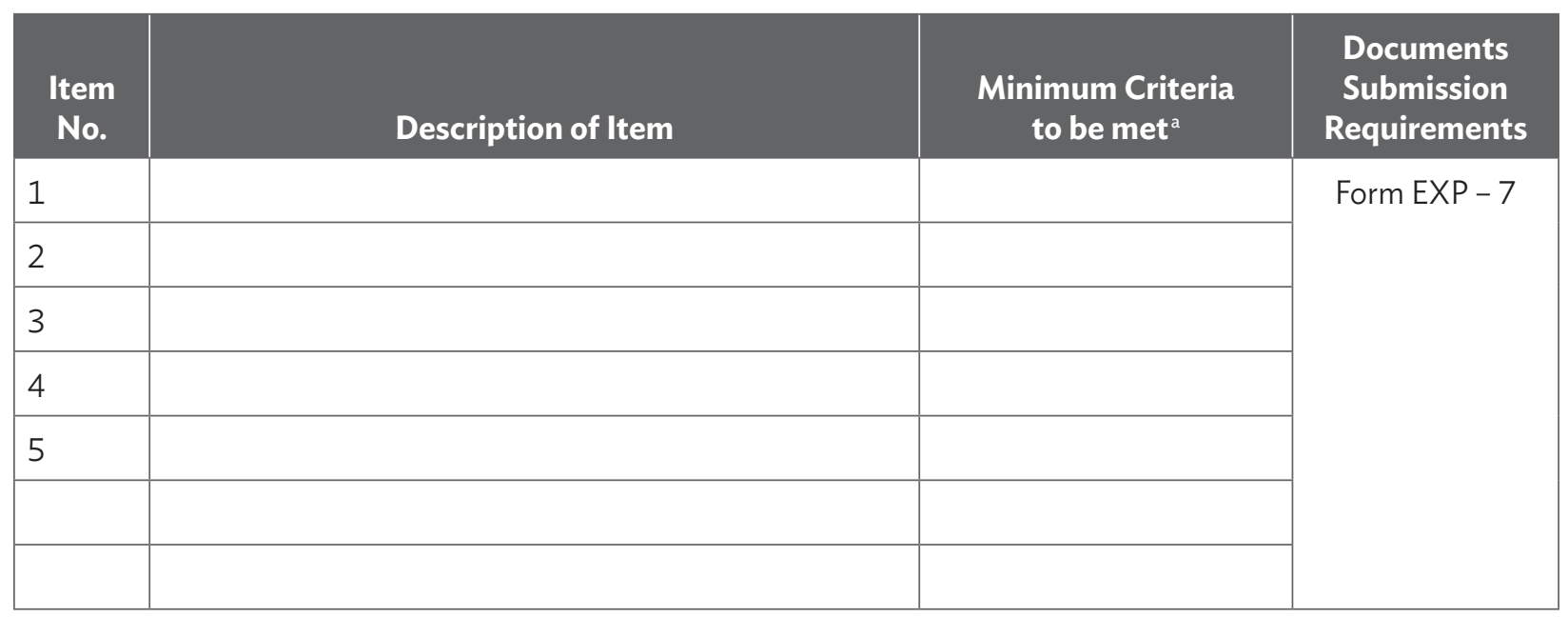

a Subcontractor must have the experience of having completed at least one contract of size and complexity similar to the proposed subcontract within the last 3 or 5 years.

In the case of a Bidder who offers to supply and install major items of plant under the contract, which the Bidder did not manufacture or otherwise produce, the Bidder shall provide the Manufacturer's authorization, using the form provided in Section 4 (Bidding Forms), showing that the Bidder has been duly authorized by the Manufacturer or producer of the related plant and equipment or component to supply and install that item in the Employer's country. Failure to submit the Manufacturer's authorization at the first instance is considered a minor, nonmaterial omission and shall be subject to clarification. However, failure of the Bidder to submit the omitted authorization shall lead to rejection of the Subcontractor or Manufacturer of the item under evaluation in accordance with ITB 38.4. 


\section{Section 4: Bidding Forms}

This section contains the forms to be completed by the Bidder and submitted as part of its Bid.

\section{Table of Forms}

Letter of Bid

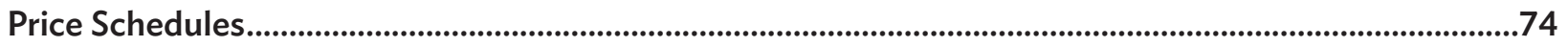

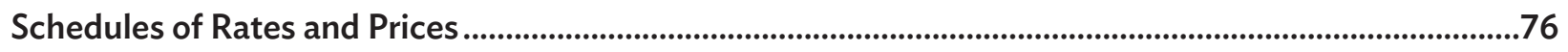

Schedule No. 1: Plant and Mandatory Spare Parts Supplied from Abroad.......................................................76

Schedule No. 2: Plant and Mandatory Spare Parts Supplied from Within the Employer's Country ....... 77

Schedule No. 3: Design Services..........................................................................................................................78

Schedule No. 4: Installation and Other Services .......................................................................................... 79

Schedule No. 5: Grand Summary ………………………………………………………………………………….... 80

Schedule No. 6: Recommended Spare Parts..................................................................................................... 81

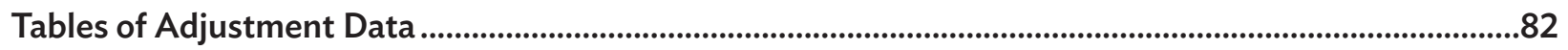

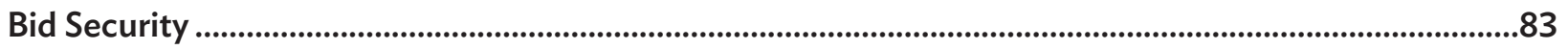

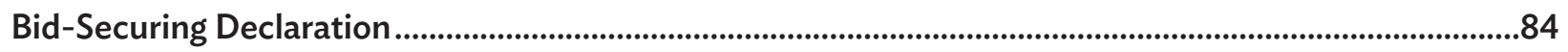

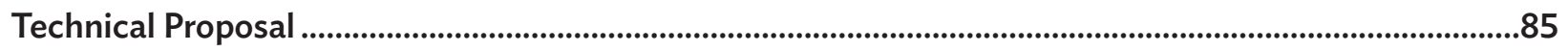

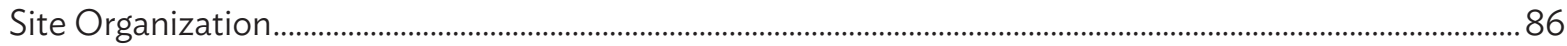

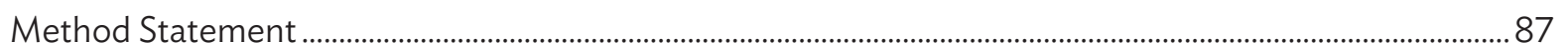

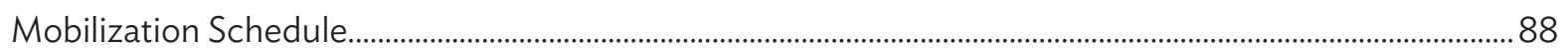

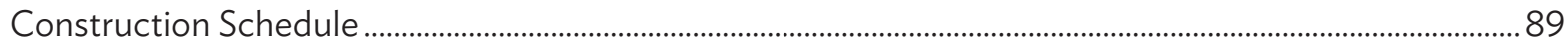

Environmental, Health and Safety Management Plan.............................................................................................89

Environmental, Health and Safety Code of Conduct .............................................................................................90

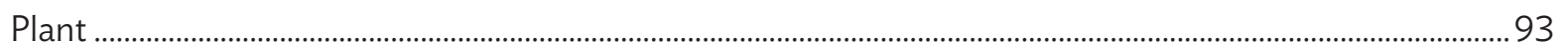

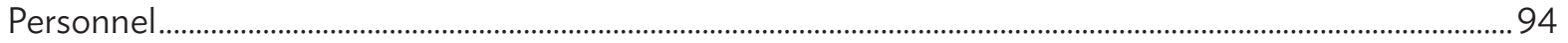

Form PER - 1: Proposed Personnel ................................................................................................................. 94

Form PER - 2: Resumé of Proposed Personnel ........................................................................................ 95

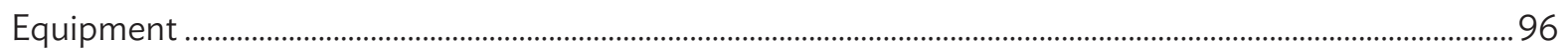

Proposed Subcontractors/Manufacturers for Major Items of Plant and Services .......................................... 97 


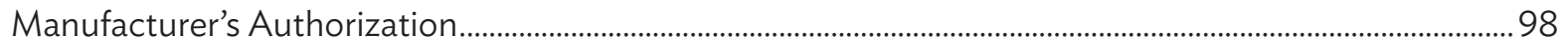

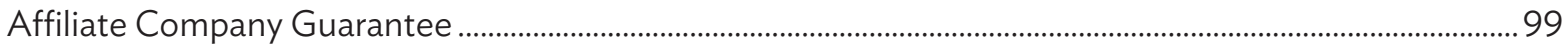

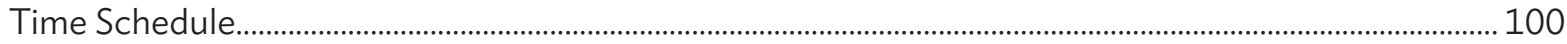

Functional Guarantee of the Proposed Facilities .......................................................................................... 101

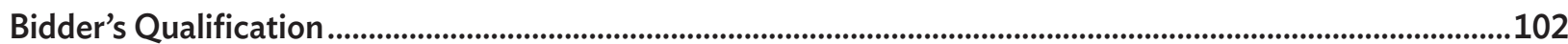

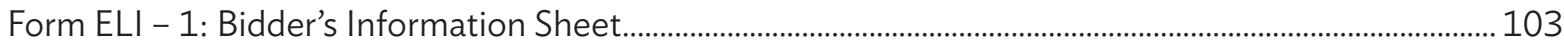

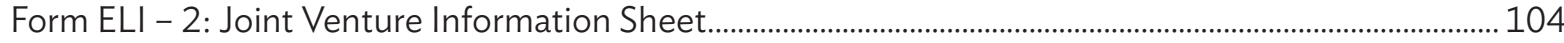

Form CON - 1: Historical Contract Nonperformance …............................................................................. 105

Form CON - 2: EHS Performance Declaration....................................................................................................107

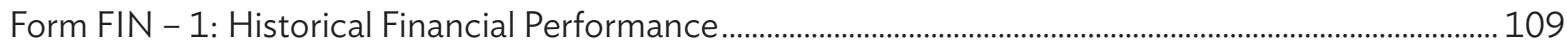

Form FIN - 2: Average Annual Turnover ........................................................................................................ 110

Form FIN - 3: Availability of Financial Resources ...................................................................................... 111

Form FIN - 4: Financial Requirements for Current Contract Commitments .............................................. 112

Form FIN - 5: Self-Assessment Tool for Bidder's Compliance to Financial Resources............................. 113

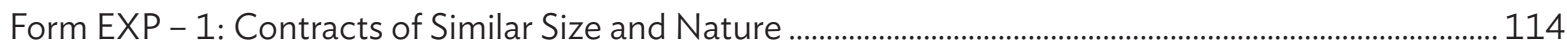

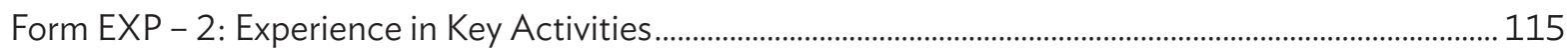

Form EXP - 3: Specific Experience in Managing Environmental, Health and Safety Aspects.................116

Form EXP - 4: Environmental, Health and Safety Certification .....................................................................117

Form EXP - 5: Environmental, Health and Safety Documentation ............................................................118

Form EXP - 6: Environmental, Health and Safety Dedicated Personnel ......................................................119

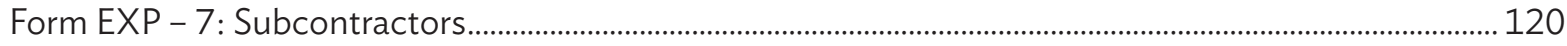




\section{Letter of Bid}

\section{NOTE}

The Bidder must accomplish the Letter of Bid on its letterhead clearly showing the Bidder's complete name and address.

Date:

OCB No.:

Invitation for Bid No.:

To: [insert complete name of the Employer]

We, the undersigned, declare that:

(a) We have examined and have no reservations to the Bidding Documents, including Addenda issued in accordance with Instructions to Bidders (ITB) 8.

(b) We acknowledge that we have read and understood ADB's Anticorruption Policy (1998) and Integrity Principles and Guidelines (2015), both as amended from time to time.

(c) We offer to design, manufacture, test, deliver, install, pre-commission, and commission in conformity with the Bidding Document the following Plant and Services: [insert narrative]

(d) The total price of our Bid, excluding any discounts offered in item (d) below is the sum of

[amount of foreign currency in words], [amount in figures], and [amount of local currency in words], [amount in figures]

The total bid price from the Grand Summary (Schedule No. 5) should be entered by the Bidder inside this box. Absence of the total bid price in the Letter of Bid may result in the rejection of the bid.

(e) The discounts offered and the methodology for their application are as follows: [insert discounts and methodology for their application if any]

(f) Our Bid shall be valid for a period of [insert bid validity period as specified in ITB 20.1 of the BDS] days starts from the date fixed for the bid submission deadline in accordance with ITB 24.1, and it shall remain binding upon us and may be accepted at any time before the expiration of that period.

(g) If our Bid is accepted, we commit to obtain a performance security in accordance with the Bidding Documents.

(h) Our firm, including any Subcontractors or Manufacturers for any part of the Contract, have or will have nationalities from eligible countries, in accordance with ITB 4.2. 
(i) We, our directors, key officers, key personnel, including any Subcontractor, consultants, subconsultants, manufacturers, service providers or Suppliers for any part of the contract, do not have any conflict of interest in accordance with ITB 4.3.

If there is any conflict of interest, please state details:

(i) Parties involved in the conflict of interest:

(ii) Details about the conflict of interest:

(j) We are not participating, as a Bidder, either individually or as partner in a Joint Venture, in more than one Bid in this bidding process in accordance with ITB 4.3(e), other than alternative offers submitted in accordance with ITB 13.

(k) Our firm, Joint Venture partners, our respective direct and indirect shareholders, directors, key officers, key personnel, associates, parent company, affiliates or subsidiaries, including any Subcontractors, consultants, subconsultants, manufacturers, service providers or Suppliers for any part of the contract, are not subject to, or not controlled by any entity or individual that is subject to, a temporary suspension or a debarment imposed by the Asian Development Bank or a debarment imposed by the Asian Development Bank in accordance with the Agreement for Mutual Enforcement of Debarment Decisions between the Asian Development Bank and other development banks. ${ }^{1}$

(I) Our firm, Joint Venture partners, our respective direct and indirect shareholders, directors, key officers, key personnel, associates, parent company, affiliates or subsidiaries, including any Subcontractors, consultants, subconsultants, manufacturers, service providers or Suppliers for any part of the contract, are not under ongoing investigation and/or sanctions proceedings by the Asian Development Bank or any multilateral development bank.

If under ongoing investigation and/or sanction proceedings by the Asian Development Bank or any multilateral development bank, please state details:

(i) Name of the multilateral development bank:

(ii) Reason for the ongoing investigation and/or allegations:

(m) Our firm, Joint Venture partners, our respective direct and indirect shareholders, directors, key officers, key personnel, associates, parent company, affiliates, or subsidiaries, including any Subcontractors, consultants, subconsultants, manufacturers, service providers or Suppliers for any part of the Contract, are not temporarily suspended, debarred, declared ineligible, or subject to any national and/or international sanctions by any country, any international organization, any multilateral development bank, and other donor agency

If so temporarily suspended, debarred, declared ineligible, or subject to any national and/or international sanctions by any country, any international organization, any multilateral development bank, and other donor agency, please state details (as applicable to each Joint Venture partner, their respective direct or

1 These institutionsinclude African Development Bank, European Bankfor Reconstruction and Development (EBRD), Inter-American Development Bank (IADB), and the World Bank Group. According to para. 9 of the Agreement, other international financial institutions may join upon the consent of all Participating Institutions and signature of a Letter of Adherence by the international financial institution substantially in the form provided (Annex B to the Agreement). Upon adherence, such international financial institution shall become a Participating Institution for purposes of the Agreement. Bidders are advised to check www.adb.org/ integrity for updates. 
indirect shareholders, directors, key officers, key personnel, associate, parent company, affiliate, subsidiaries, Subcontractors, consultants, subconsultants, manufacturers, service providers and/or Suppliers):

(i) Name of Institution:

(ii) Period of the temporary suspension, debarment, ineligibility, or national or international sanction [start and end date]:

(iii) Reason for the temporary suspension, debarment, ineligibility, or national or international sanction:

(n) Our firm, Joint Venture partners, associates, parent company affiliates or subsidiaries, including any Subcontractors, consultants, subconsultants, manufacturers, service providers, Suppliers, key officers, directors and key personnel have never been charged or convicted with any criminal offense (including felonies but excluding misdemeanors) or infractions and/or violations of ordinance; nor charged or found liable in any civil or administrative proceedings in the last 10 years; or undergoing investigation for such, or subject to any criminal, civil or administrative orders, monitorship or enforcement actions.

If so charged, convicted/found liable, under ongoing investigation, or subject to orders, monitorship or enforcement actions, please state details:

(i) Nature of the offense/violation, proceedings, investigation, and/or monitorship or enforcement actions:

(ii) Court, area of jurisdiction and/or the enforcement agency:

(iii) Resolution [i.e. dismissed, settled, or convicted; duration of penalty]:

(iv) Other relevant details [please specify]:

(o) Our firm, Joint Venture partners, our respective direct and indirect shareholders, directors, key officers, key personnel, associates, affiliates or subsidiaries, including any Subcontractors, consultants, subconsultants, manufacturers, service providers or Suppliers, can make and receive electronic fund transfer payments through the international banking system or otherwise discharge the Employer's obligation upon initiation of wire transfer.

If unable to make or receive funds through the international banking system or otherwise discharge the Employer's obligation upon initiation of wire transfer, please state the details:

(i) Nature of the restriction:

(ii) Jurisdiction of the restriction:

(iii) Other relevant details:

(p) Our firm, Joint Venture partners, associates, parent company, affiliates, or subsidiaries, including any Subcontractors, consultants, subconsultants, manufacturers, service providers or Suppliers, key officers, directors and key personnel are not from a country that is prohibited to export goods or services to, or receive any payments from the Employer's country and are not prohibited to receive payments for particular goods or services by the Employer's country by an act of compliance with a decision of the United Nations Security Council taken under Chapter VII of the Charter of the United Nations.

(q) We understand that it is our obligation to notify the Employer of any changes in connection with the matters described in paragraphs (i), (k), (I), (m), (n), (o), (p) and (t) of this Letter of Bid. 
(r) [We are not a government-owned enterprise]/[We are a government-owned enterprise but meet the requirements of ITB 4.5]. ${ }^{2}$

(s) We have not been suspended nor declared ineligible by the Employer based on execution of a Bid-Securing Declaration in accordance with ITB 4.6.

(t) We have paid, or intend to pay, either directly or indirectly, the following commissions, gratuities, or fees with respect to the bidding process or execution of the Contract: ${ }^{3}$

Name of Recipient

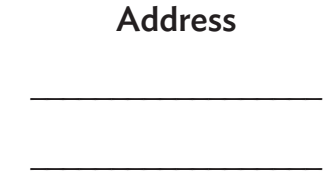

Reason

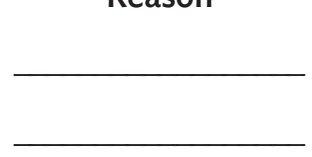

Amount

(u) We understand that this Bid, together with your written acceptance thereof included in your notification of award through the issuance of Letter of Acceptance, shall constitute a binding contract between us until a formal contract is prepared and executed.

(v) We understand that you are not bound to accept the lowest evaluated Bid or any other Bid that you may receive.

(w) At any time following submission of our Bid, we shall permit, and shall cause our Joint Venture partners, directors, key officers, key personnel, associates, parent company, affiliates or subsidiaries, including any Subcontractors, consultants, subconsultants, manufacturers, service providers or Suppliers for any part of the contract to permit ADB or its representative to inspect our sites, assets, accounts and records and other documents relating to the bid submission and to have them audited by auditors appointed by ADB. We understand that failure of this obligation may constitute obstructive practice that may result in debarment and/or contract termination.

(x) Regardless of whether the contract will be awarded to us, we shall preserve all accounts, records, and other documents related to bid submission for at least 3 years from the date of submission of the bid or the period prescribed in applicable law, whichever is longer.

(y) If we are awarded the contract, we shall preserve all accounts, records and other documents related to the procurement and execution of the contract for at least 5 years after the completing the works contemplated in the relevant contracts or the period prescribed in applicable law, whichever is longer.

(z) If our Bid is accepted, we commit to mobilizing key equipment and personnel in accordance with the requirements set forth in Section 6 (Employer's Requirements) and our technical proposal, or as otherwise agreed with the Employer.

Use one of the two options as appropriate.

If none has been paid or is to be paid, indicate "None." 
(aa) We certify on behalf of the Bidder, that the information provided in the bid has been fully reviewed, given in good faith, and to the best of our knowledge is true and complete. We understand that it is our obligation to inform the Employer of any changes to the information as and when it becomes known to us. We understand that any misrepresentation that knowingly or recklessly misleads, or attempts to mislead may lead to the automatic rejection of the Bid or cancellation of the contract, if awarded, and may result in remedial actions, in accordance with ADB's Anticorruption Policy (1998, as amended to date) and Integrity Principles and Guidelines (2015, as amended from time to time).

Name: [insert complete name of person signing the bid]

In the capacity of [insert legal capacity of person signing the bid]

Signed: [insert signature of person whose name and capacity are shown above]

Duly authorized to sign the Bid for and on behalf of [insert complete name of the Bidder]

Date: [insert date of signing] 


\section{Price Schedules}

\section{NOTES}

To receive consistent and responsive bids, it is recommended that Employers include a Preamble to the price schedules, indicating exactly what is required of Bidders when completing and pricing their bids.

The following Preamble is given as an example only. Employers are responsible for ensuring that the Preamble included in the bidding document is complete and appropriate for the contract in question.

\section{PREAMBLE}

\section{General}

1. The Price Schedules are divided into separate Schedules as follows:

Schedule No. 1: Plant and Mandatory Spare Parts Supplied from Abroad

Schedule No. 2: Plant and Mandatory Spare Parts Supplied from Within the Employer's Country

Schedule No. 3: Design Services

Schedule No. 4: Installation and Other Services

Schedule No. 5: Grand Summary

Schedule No. 6: Recommended Spare Parts

2. The Schedules do not generally give a full description of the plant to be supplied and the services to be performed under each item. Bidders shall be deemed to have read the Employer's Requirements and other sections of the Bidding Document and reviewed the Drawings to ascertain the full scope of the requirements included in each item prior to filling in the rates and prices. The entered rates and prices shall be deemed to cover the full scope as aforesaid, including overheads and profit.

3. If Bidders are unclear or uncertain as to the scope of any item, they shall seek clarification in accordance with ITB 7 prior to submitting their bid.

\section{Pricing}

4. The units and rates in figures entered into the Price Schedules should be typewritten or if written by hand, must be in print form. Price Schedules not presented accordingly may be considered nonresponsive. Any alterations necessary due to errors, etc., shall be initialed by the Bidder.

As specified in the Bid Data Sheet and Special Conditions of Contract, prices shall be fixed and firm for the duration of the Contract, or prices shall be subject to adjustment in accordance with the corresponding Appendix (Price Adjustment) to the Contract Agreement. 
5. Bid prices shall be quoted in the manner indicated and in the currencies specified in the Instructions to Bidders in the Bidding Document.

For each item, Bidders shall complete each appropriate column in the respective Schedules, giving the price breakdown as indicated in the Schedules.

Prices given in the Schedules against each item shall be for the scope covered by that item as detailed in Section 6 (Employer's Requirements) or elsewhere in the Bidding Document.

6. Payments will be made to the Contractor in the currency or currencies indicated under each respective item.

7. When requested by the Employer for the purposes of making payments or partial payments, valuing variations or evaluating claims, or for such other purposes as the Employer may reasonably require, the Contractor shall provide the Employer with a breakdown of any composite or lump sum items included in the Schedules. 


\section{Schedules of Rates and Prices}

Schedule No. 1: Plant and Mandatory Spare Parts Supplied from Abroad

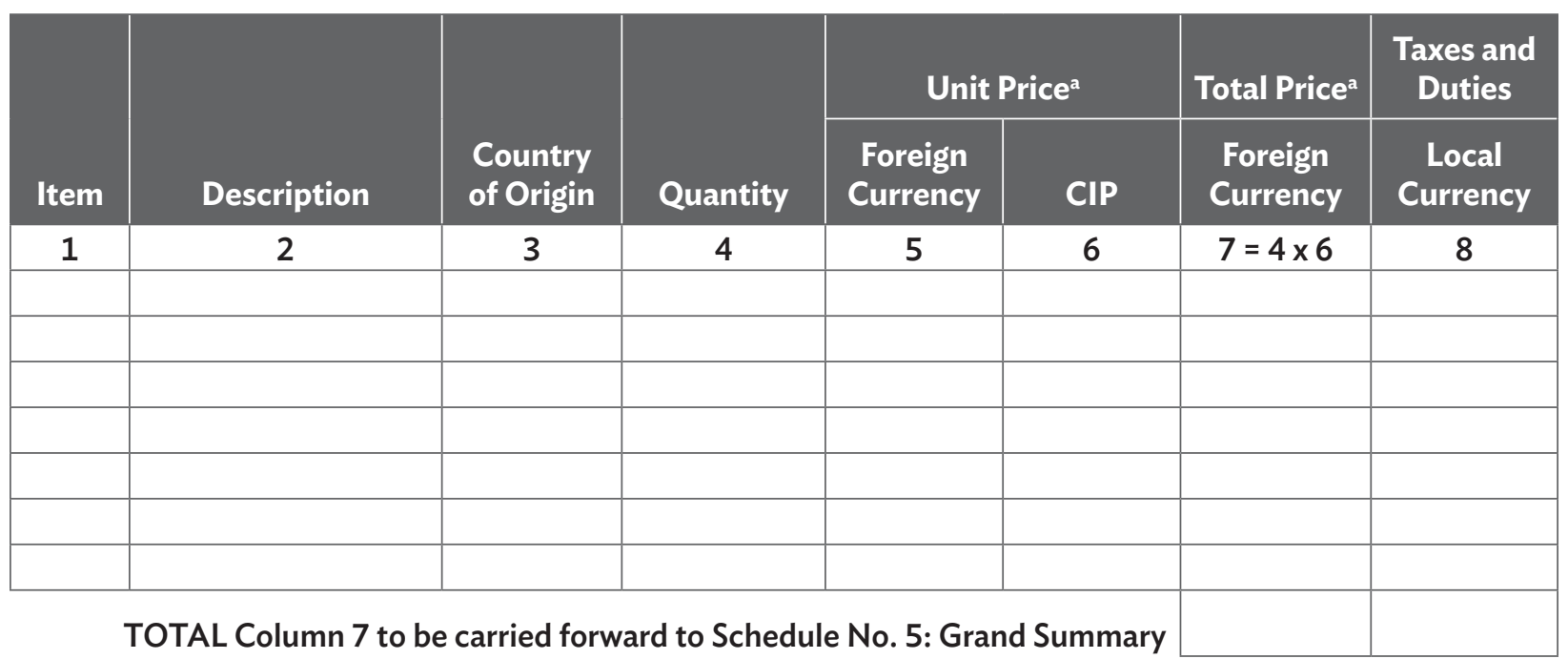

a Specify currencies in accordance with ITB 19.1 of the BDS. Create additional columns for foreign currencies if so required.

Name of Bidder

Signature of Bidder

Country of Origin Declaration Form

\begin{tabular}{|l|c|c|}
\hline Item & Description & Country \\
\hline & & \\
\hline & & \\
\hline & & \\
\hline & & \\
\hline
\end{tabular}


Schedule No. 2: Plant and Mandatory Spare Parts Supplied from Within the Employer's Country

\begin{tabular}{|c|c|c|c|c|c|c|}
\hline \multirow[b]{2}{*}{ Item } & \multirow[b]{2}{*}{ Description } & \multirow[b]{2}{*}{ Quantity } & \multicolumn{2}{|c|}{ Unit Price $^{a}$} & \multirow[b]{2}{*}{$\begin{array}{c}\text { Total EXW } \\
\text { Price }^{a}\end{array}$} & \multirow[b]{2}{*}{$\begin{array}{l}\text { Sales and } \\
\text { other taxes }\end{array}$} \\
\hline & & & $\begin{array}{l}\text { Local } \\
\text { Currency }\end{array}$ & EXW Price & & \\
\hline 1 & 2 & 3 & 4 & 5 & $6=3 \times 5$ & 7 \\
\hline & & & & & & \\
\hline & & & & & & \\
\hline & & & & & & \\
\hline & & & & & & \\
\hline & & & & & & \\
\hline & & & & & & \\
\hline & & & & & & \\
\hline & & & & & & \\
\hline & & & & & & \\
\hline & & & & & & \\
\hline & & & & & & \\
\hline & & & & & & \\
\hline & & & & & & \\
\hline & & & & & & \\
\hline & in 6 to be & ard to Sch & le No. 5: G & d Summary & & \\
\hline
\end{tabular}

a Specify currency in accordance with ITB 19.1 of the BDS.

b Column 5, EXW Price shall include all customs duties and sales and other taxes already paid or payable on the components and raw materials used in the manufacture or assembly of the item or the customs duties and sales and other taxes already paid on previously imported items.

Name of Bidder

Signature of Bidder 
Schedule No. 3: Design Services

\begin{tabular}{|c|c|c|c|c|c|c|}
\hline \multirow[b]{2}{*}{ Item } & \multirow[b]{2}{*}{ Description } & \multirow[b]{2}{*}{ Quantity } & \multicolumn{2}{|c|}{ Unit Price } & \multicolumn{2}{|c|}{ Total Price ${ }^{a}$} \\
\hline & & & $\begin{array}{l}\text { Local } \\
\text { Currency } \\
\text { Portion }\end{array}$ & $\begin{array}{l}\text { Foreign } \\
\text { Currency } \\
\text { Portion }\end{array}$ & $\begin{array}{l}\text { Local } \\
\text { Currency } \\
\text { Portion }\end{array}$ & $\begin{array}{c}\text { Foreign } \\
\text { Currency } \\
\text { Portion }\end{array}$ \\
\hline 1 & 2 & 3 & 4 & 5 & $6=3 \times 4$ & $7=3 \times 5$ \\
\hline & & & & & & \\
\hline & & & & & & \\
\hline & & & & & & \\
\hline & & & & & & \\
\hline & & & & & & \\
\hline & & & & & & \\
\hline & & & & & & \\
\hline & & & & & & \\
\hline & & & & & & \\
\hline & & & & & & \\
\hline & & & & & & \\
\hline TOT & d 7 to be $c$ & to Sched & No. 5: G & Summary & & \\
\hline
\end{tabular}

a Specify currency in accordance with ITB 19.1 of the BDS.

Name of Bidder

Signature of Bidder 
Schedule No. 4: Installation and Other Services

\begin{tabular}{|c|c|c|c|c|c|c|}
\hline \multirow[b]{2}{*}{ Item } & \multirow[b]{2}{*}{ Description } & \multirow[b]{2}{*}{ Quantity } & \multicolumn{2}{|c|}{ Unit Price $^{a}$} & \multicolumn{2}{|c|}{ Total Price $^{a}$} \\
\hline & & & $\begin{array}{l}\text { Local } \\
\text { Currency } \\
\text { Portion }\end{array}$ & $\begin{array}{l}\text { Foreign } \\
\text { Currency } \\
\text { Portion }\end{array}$ & $\begin{array}{l}\text { Local } \\
\text { Currency } \\
\text { Portion }\end{array}$ & $\begin{array}{l}\text { Foreign } \\
\text { Currency } \\
\text { Portion }\end{array}$ \\
\hline 1 & 2 & 3 & 4 & 5 & $6=3 \times 4$ & $7=3 \times 5$ \\
\hline 1 & $\ldots \ldots$ & & & & & \\
\hline 2 & $\ldots \ldots$ & & & & & \\
\hline 3 & $\ldots \ldots$ & & & & & \\
\hline 4 & $\ldots \ldots$ & & & & & \\
\hline 5 & $\ldots \ldots$ & & & & & \\
\hline 6 & $\begin{array}{l}\text { STI/STD and HIV/AIDS alleviation } \\
\text { program }^{b}\end{array}$ & & & & & \\
\hline etc. & $\ldots$ & & & & & \\
\hline & & & & & & \\
\hline & & & & & & \\
\hline & & & & & & \\
\hline TO1 & AL Columns 6 and 7 to be carried fo & I caho & & & & \\
\hline
\end{tabular}

a Specify currency in accordance with ITB 19.1 of the BDS.

b As described in SCC 22.2.7.

Name of Bidder

Signature of Bidder 
Schedule No. 5: Grand Summary

\begin{tabular}{|c|c|c|c|}
\hline \multirow{2}{*}{$\begin{array}{l}\text { Schedule } \\
\text { No. }\end{array}$} & \multirow[b]{2}{*}{ Title } & \multicolumn{2}{|c|}{ Total Price $^{a}$} \\
\hline & & Foreign & Local \\
\hline 1 & Plant and Mandatory Spare Parts Supplied from Abroad & & \\
\hline 2 & $\begin{array}{l}\text { Plant and Mandatory Spare Parts Supplied from Within } \\
\text { the Employer's Country }\end{array}$ & & \\
\hline 3 & Design Services & & \\
\hline 4 & Installation and Other Services & & \\
\hline & $\begin{array}{r}\text { Grand Total to be carried forward } \\
\text { to Letter of Bid }\end{array}$ & & \\
\hline
\end{tabular}

a Specify currency in accordance with ITB 19.1 of the BDS. Create additional columns for foreign currencies if so required.

b Taxes and/or duties from Schedules 1 and 2 may be added to the contract price in accordance with GCC 14 (Taxes and Duties) but are excluded from bid evaluation in accordance with ITB 36.4 .

Name of Bidder

Signature of Bidder 
Schedule No. 6: Recommended Spare Parts

\begin{tabular}{|c|c|c|c|c|c|c|}
\hline \multirow[b]{2}{*}{ Item } & \multirow[b]{2}{*}{ Description } & \multirow[b]{2}{*}{ Quantity } & \multicolumn{2}{|c|}{ Unit Price } & \multicolumn{2}{|c|}{ Total Price $^{\mathrm{a}}$} \\
\hline & & & $\begin{array}{c}\text { EXW } \\
\text { Local } \\
\text { Parts } \\
\text { Local } \\
\text { Currency }\end{array}$ & $\begin{array}{c}\text { CIP } \\
\text { Imported } \\
\text { Parts } \\
\text { Foreign } \\
\text { Currency }\end{array}$ & $\begin{array}{l}\text { Local } \\
\text { Currency } \\
\text { Portion }\end{array}$ & $\begin{array}{l}\text { Foreign } \\
\text { Currency } \\
\text { Portion }\end{array}$ \\
\hline 1 & 2 & 3 & 4 & 5 & $6=3 \times 4$ & $7=3 \times 5$ \\
\hline & & & & & & \\
\hline & & & & & & \\
\hline & & & & & & \\
\hline & & & & & & \\
\hline & & & & & & \\
\hline & & & & & & \\
\hline & & & & & & \\
\hline & & & & & & \\
\hline & & & & & & \\
\hline & & & & & & \\
\hline & & & & & & \\
\hline & & & & TOTAL & & \\
\hline
\end{tabular}

a Specify currency in accordance with ITB 19.1 of the BDS.

Name of Bidder

Signature of Bidder 


\section{Tables of Adjustment Data}

Table A - Local Currency

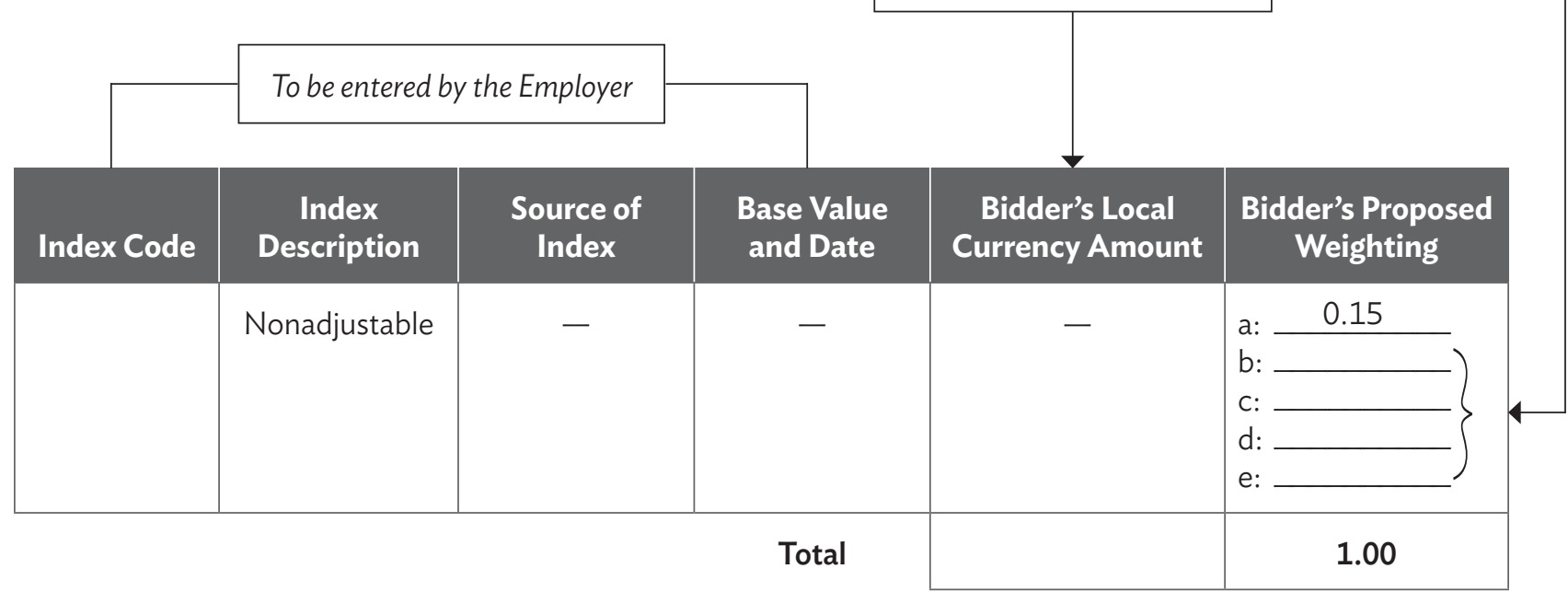

\section{Table B - Foreign Currency}

Name of Currency: [Insert name of currency. If the bidder wishes to quote in more than one foreign currency, this table should be repeated for each foreign currency]

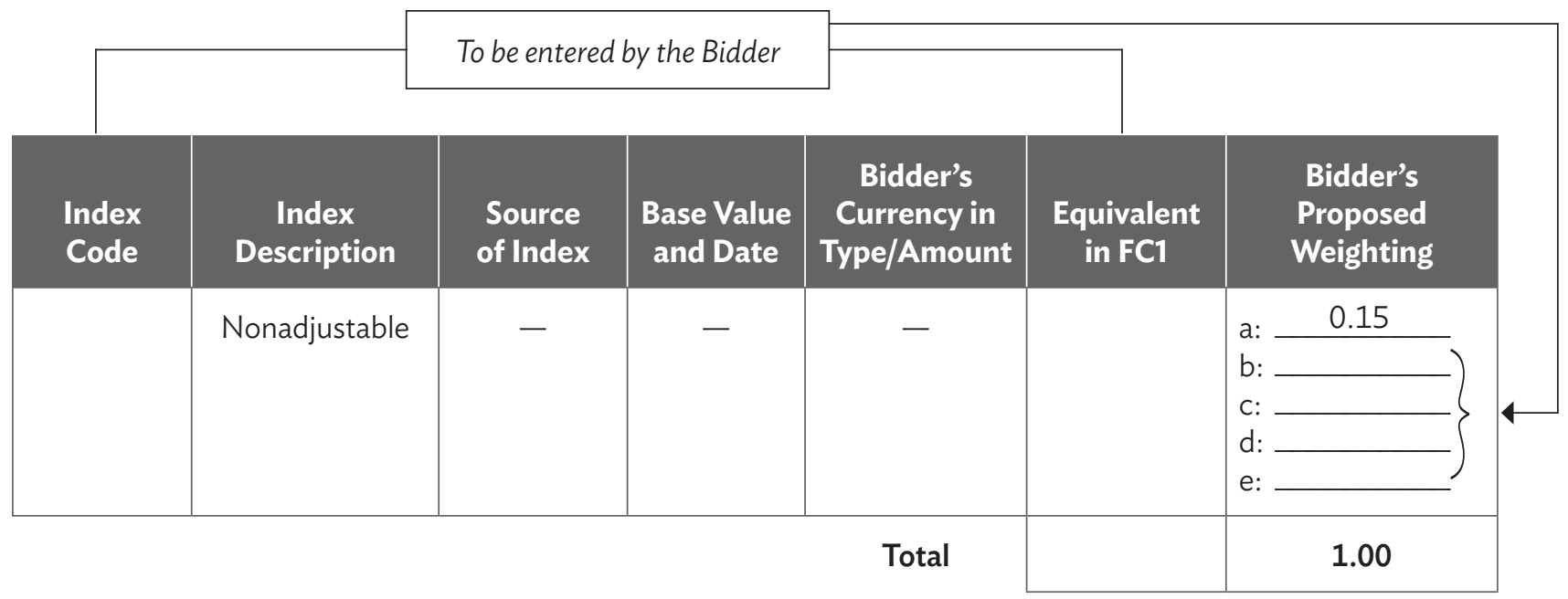

\section{NOTES}

The base date shall be the date 28 days prior to the deadline for submission of the bid.

Tables of Adjustment Data shall only be included if prices are to be quoted as adjustable prices in accordance with ITB 18.6. 


\section{Bid Security}

\section{Bank Guarantee}

[Bank's name, and address of issuing branch or office $]^{1}$

Beneficiary: [insert name and address of the Employer]

Date:

Bid Security No.:

We have been informed that [insert name of the Bidder] (hereinafter called "the Bidder") has submitted to you its bid dated [insert date] (hereinafter called "the Bid") for the execution of [insert name of contract] under Invitation for Bids No. [insert IFB number] ("the IFB").

Furthermore, we understand that, according to your conditions, bids must be supported by a bid guarantee.

At the request of the Bidder, we [insert name of bank] hereby irrevocably undertake to pay you any sum or sums not exceeding in total an amount of [insert amount in words] [insert amount in figures] upon receipt by us of your first demand in writing accompanied by a written statement, stating that the Bidder is in breach of its obligation(s) under the bid conditions, because the Bidder

(a) has withdrawn its Bid during the period of bid validity specified by the Bidder in the Letter of Bid; or

(b) does not accept the correction of errors in accordance with the Instruction to Bidders (hereinafter "the (TB"); or

(c) having been notified of the acceptance of its Bid by the Employer during the period of bid validity, (i) fails or refuses to execute the Contract Agreement, or (ii) fails or refuses to furnish the Performance Security, in accordance with the ITB.

This guarantee will expire (a) if the Bidder is the successful Bidder, upon our receipt of copies of the Contract Agreement signed by the Bidder and the Performance Security issued to you upon the instruction of the Bidder; or (b) if the Bidder is not the successful Bidder, upon the earlier of (i) our receipt of a copy of your notification to the Bidder of the name of the successful Bidder, or (ii) 28 days after the expiration of the Bidder's bid.

Consequently, any demand for payment under this guarantee must be received by us at the office indicated above on or before that date.

This guarantee is subject to the Uniform Rules for Demand Guarantees (URDG) 2010 Revision, ICC Publication No. 758. ${ }^{2}$

[Authorized signature(s) and bank's seal (where appropriate)]

All italicized text is for use in preparing this form and shall be deleted from the final document.

Or the employer may use "Uniform Rules for Demand Guarantees (URDG), ICC Publication No. 458” as appropriate. 


\section{Bid-Securing Declaration}

Date: [insert date (as day, month, and year)]

Bid No.: [insert number of bidding process]

Alternative No.: [insert identification no. if this is a bid for an alternative]

To: [insert complete name of the Employer]

We, the undersigned, declare that:

We understand that, according to your conditions, Bids must be supported by a Bid-Securing Declaration.

We accept that we will automatically be suspended from being eligible for bidding in any contract with the Borrower for the period of time of [insert number of years indicated in ITB 21.2 of the BDS] starting on the date that we receive a notification from the Employer, if we are in breach of our obligation(s) under the bid conditions, because we

(a) have withdrawn our Bid during the period of bid validity specified in the Letter of Bid; or

(b) do not accept the correction of errors in accordance with the Instructions to Bidders (hereinafter "the ITB"); or

(c) having been notified of the acceptance of our Bid by the Employer during the period of bid validity, (i) fail or refuse to execute the Contract, if required; or (ii) fail or refuse to furnish the Performance Security, in accordance with the ITB.

We understand that this Bid-Securing Declaration shall expire if we are not the successful Bidder, upon the earlier of (i) our receipt of your notification to us of the name of the successful Bidder; or (ii) 28 days after the expiration of our Bid.

Signed: [insert signature of person whose name and capacity are shown]

In the capacity of [insert legal capacity of person signing the Bid-Securing Declaration]

Name: [insert complete name of person signing the Bid-Securing Declaration]

Duly authorized to sign the bid for and on behalf of [insert complete name of the Bidder]

Dated on day of [insert date of signing]

Corporate Seal [where appropriate] 


\section{Technical Proposal}

Site Organization

Method Statement

Mobilization Schedule

Construction Schedule

Environmental, Health and Safety Management Plan

Environmental, Health and Safety Code of Conduct

Plant

Personnel

Equipment

Proposed Subcontractors for Major Items of Plant and Services

Manufacturer's Authorization

Affiliate Company Guarantee

Time Schedule

Functional Guarantee of the Proposed Facilities 
Site Organization 
Method Statement 


\section{Mobilization Schedule}

The Mobilization Schedule should reflect the no-objection request and approval step for Site Specific Environmental, Health and Safety Management Plan as per Contract Conditions. 


\section{Construction Schedule}

The construction schedule shall include the following key milestones:

\section{Environmental, Health and Safety Management Plan (EHSMP)}

The Bidder shall submit an outline Environmental, Health and Safety Management Plan (EHSMP) commensurate with the risks and impacts of the proposed works and activities. These strategies and plans shall describe in detail the actions, materials, equipment, management processes, etc. that will be implemented by the Contractor, and its subcontractors.

In developing these strategies and plans, the Bidder shall have regard to the EHS provisions of the contract and EHS risks including those as may be more fully described in Section 6 (Employer's Requirements).

\section{NOTE}

The Employer shall assess whether the proposed site organization, method statement, mobilization schedule, and construction schedule and environmental, health and safety management plan described in Section 4 (Bidding Forms) are presented in a consistent manner and comply with requirements stipulated in Section 6 (Employer's Requirements) without material deviation, reservation, or omission. 
Environmental, Health and Safety Code of Conduct

\author{
Environmental, Health and Safety Code of Conduct for Contractor's Personnel Form
}

\title{
NOTE TO EMPLOYER
}

The following minimum requirements shall not be modified. The Employer may add additional requirements to address identified issues, informed by relevant environmental, health and safety assessment.

Delete this Box prior to issuance of the bidding documents.

\section{NOTE TO BIDDER}

The minimum content of the EHS Code of Conduct form as set out by the Employer shall not be substantially modified. However, the Bidder may add requirements as appropriate, including to take into account Contract-specific issues/risks.

The Bidder shall initial and submit the EHS Code of Conduct form as part of its bid.

\section{ENVIRONMENTAL, HEALTH AND SAFETY CODE OF CONDUCT FOR CONTRACTOR'S PERSONNEL}

We are the Contractor, [enter name of Contractor]. We have signed a contract with [enter name of Employer] for [enter description of the Works]. These Works will be carried out at [enter the Site and other locations where the Works will be carried out]. Our contract requires us to implement measures to address environmental, health and safety risks related to the Works.

This EHS Code of Conduct is part of our measures to deal with environmental, health and safety risks related to the Works. It applies to all our staff, labourers and other employees at the Works Site or other places where the Works are being carried out. It also applies to the personnel of each subcontractor and any other personnel assisting us in the execution of the Works. All such persons are referred to as "Contractor's Personnel" and are subject to this EHS Code of Conduct.

This EHS Code of Conduct identifies the behavior that we require from all Contractor's Personnel.

Our workplace is an environment where unsafe, offensive, abusive or violent behavior will not be tolerated and where all persons should feel comfortable raising issues or concerns without fear of retaliation. 


\section{REQUIRED CONDUCT}

Contractor's Personnel shall:

1. carry out his/her duties competently and diligently;

2. comply with this EHS Code of Conduct and all applicable laws, regulations and other requirements, including requirements to protect the health, safety and well-being of other Contractor's Personnel and any other person;

3. maintain a safe working environment including by:

a. ensuring that workplaces, machinery, equipment and processes under each person's control are safe and without risk to health;

b. wearing required personal protective equipment;

c. using appropriate measures relating to chemical, physical and biological substances and agents; and

d. following applicable emergency operating procedures.

4. report work situations that he/she believes are not safe or healthy and remove himself/herself from a work situation which he/she reasonably believes presents an imminent and serious danger to his/her life or health;

5. treat other people with respect, and not discriminate against specific groups such as women, people with disabilities, migrant workers or children;

6. report violations of this EHS Code of Conduct; and

7. not retaliate against any person who reports violations of this EHS Code of Conduct, whether to us or the Employer, or who makes use of the grievance mechanism for Contractor's Personnel or the project's Grievance Redress Mechanism.

\section{RAISING CONCERNS}

If any person observes behavior that he/she believes may represent a violation of this EHS Code of Conduct, or that otherwise concerns him/her, he/she should raise the issue promptly. This can be done by call [] to reach the Contractor's hotline (if any) and leave a message.

The person's identity will be kept confidential, unless reporting of allegations is mandated by the country law. Anonymous complaints or allegations may also be submitted and will be given all due and appropriate consideration. We take seriously all reports of possible misconduct and will investigate and take appropriate action. We will provide warm referrals to service providers that may help support the person who experienced the alleged incident, as appropriate. 


\section{CONSEQUENCES OF VIOLATING THE ENVIRONMENTAL, HEALTH AND SAFETY CODE OF CONDUCT}

Any violation of this EHS Code of Conduct by Contractor's Personnel may result in serious consequences, up to and including termination and possible referral to legal authorities.

\section{FOR CONTRACTOR'S PERSONNEL:}

I have received a copy of this EHS Code of Conduct written in a language that I comprehend. I understand that if I have any questions about this EHS Code of Conduct, I can contact [enter name of Contractor's contact person(s) with relevant experience] requesting an explanation.

Name of Contractor's Personnel: [insert name]

Signature:

Date: (day month year):

Countersignature of authorized representative of the Contractor:

Signature:

Date: (day month year): 
Plant 


\section{Personnel}

\section{Form PER - 1: Proposed Personnel}

Bidders should provide the details of proposed personnel and their experience record in the relevant Information Forms below for each of the candidate.

\begin{tabular}{|l|l|}
\hline \multirow{2}{*}{1.} & Title of position \\
\hline \multirow{2}{*}{2.} & Name \\
\cline { 2 - 2 } & Title of position \\
\hline \multirow{2}{*}{3.} & Name \\
\cline { 2 - 2 } & Title of position \\
\hline \multirow{2}{*}{4.} & Name \\
\cline { 2 - 2 } & Title of position \\
\hline \multirow{2}{*}{5.} & Name \\
\cline { 2 - 2 } & Title of position \\
\hline \multirow{2}{*}{6.} & Name \\
\cline { 2 - 3 } & Title of position \\
\cline { 2 - 2 } & Name \\
\hline \multirow{2}{*}{ etc. } & Title of position \\
\cline { 2 - 2 } & Name \\
\hline
\end{tabular}

Note: All titles of positions will be as listed in Section 6 (Employer's Requirements). 
Form PER - 2: Resumé of Proposed Personnel

The Bidder shall provide all the information requested below. Use one form for each position.

\begin{tabular}{|c|c|c|}
\hline Position & & \\
\hline \multirow{5}{*}{$\begin{array}{l}\text { Personnel } \\
\text { information }\end{array}$} & Full Legal Name & Date of Birth \\
\hline & Known as & Place of Birth \\
\hline & Nationality & Citizenship \\
\hline & $\begin{array}{l}\text { Type of government ID } \\
\text { Attach a copy of ID to this form }\end{array}$ & ID number \\
\hline & Professional qualifications & \\
\hline \multirow{5}{*}{$\begin{array}{l}\text { Present } \\
\text { employment }\end{array}$} & \multicolumn{2}{|l|}{ Name of employer } \\
\hline & \multicolumn{2}{|l|}{ Address of employer } \\
\hline & Telephone & Contact (manager/personnel officer) \\
\hline & Fax & E-mail \\
\hline & Job title & Years with present employer \\
\hline
\end{tabular}

Summarize professional experience in reverse chronological order. Indicate particular technical and managerial experience relevant to the project.

\begin{tabular}{|l|c|l|}
\hline From & To & Company/Project/Position/Relevant Technical and Management Experience \\
\hline & & \\
\hline & & \\
\hline & & \\
\hline & & \\
\hline & & \\
\hline & & \\
\hline & & \\
\hline
\end{tabular}




\section{Equipment}

\section{Form EQU: Equipment}

The Bidder shall provide adequate information and details to demonstrate clearly that it has the capability to meet the equipment requirements indicated in Section 6 (Employer's Requirements), using the Forms below. A separate Form shall be prepared for each item of equipment listed, or for alternative equipment proposed by the Bidder.

\begin{tabular}{|l|l|l|}
\hline \multicolumn{2}{|l|}{ Item of Equipment } \\
\hline $\begin{array}{l}\text { Equipment } \\
\text { Information }\end{array}$ & Name of manufacturer & Model and power rating \\
\cline { 2 - 3 } & Capacity & Year of manufacture \\
\hline $\begin{array}{l}\text { Current } \\
\text { Status }\end{array}$ & Current location \\
\cline { 2 - 3 } & Details of current commitments \\
\hline Source & $\begin{array}{l}\text { Indicate source of the equipment } \\
\square \text { Owned } \square \text { Rented } \square \text { Leased } \quad \square \text { Specially manufactured }\end{array}$ \\
\hline
\end{tabular}

Omit the following information for equipment owned by the Bidder.

\begin{tabular}{|l|l|l|}
\hline \multirow{2}{*}{ Owner } & \multicolumn{2}{|l|}{ Name of owner } \\
\cline { 2 - 3 } & \multicolumn{2}{|l|}{ Address of owner } \\
\cline { 2 - 3 } & Telephone & Contact name and title \\
\cline { 2 - 3 } & Fax & Telex \\
\hline \multirow{2}{*}{ Agreements } & Details of rental/lease/manufacture agreements specific to the project \\
& \multicolumn{2}{|l}{} \\
\hline
\end{tabular}




\section{Proposed Subcontractors and/or Manufacturers for Major Items of Plant and Services}

The following Subcontractors and/or Manufacturers are proposed for carrying out the item of the facilities indicated based on Criterion 2.5 of Section 3 (Evaluation and Qualification Criteria). Bidders are free to propose more than one for each item.

\begin{tabular}{|l|c|l|}
\hline Major Items of Plant and Services & $\begin{array}{c}\text { Proposed Subcontractors and/or } \\
\text { Manufacturers }\end{array}$ & Nationality \\
\hline & & \\
\hline
\end{tabular}




\section{Manufacturer's Authorization}

Date: [insert date (as day, month, and year) of bid submission]

OCB No.: [insert number of bidding process]

To: [insert complete name of the Employer]

\section{WHEREAS}

We [insert complete name of the manufacturer or manufacturer's authorized agent], who are official Manufacturers or agent authorized by the Manufacturer of [insert type of goods manufactured], having factories at [insert full address of manufacturer's factories], do hereby authorize [insert complete name of the Bidder] to submit a bid the purpose of which is to provide the following goods, manufactured by us [insert name and/or brief description of the goods], and to subsequently negotiate and sign the Contract.

We hereby extend our full guarantee and warranty in accordance with Clause 27 of the General Conditions of Contract, with respect to the goods offered by the above firm.

Signed: [insert signature(s) of authorized representative(s) of the manufacturer]

Name: [insert complete name(s) of authorized representative(s) of the manufacturer]

Title: [insert title]

Duly authorized to sign this Authorization on behalf of [insert complete name of the manufacturer]

Dated on day of [insert date of signing]

\section{NOTE}

The Bidder shall require the manufacturer to fill out this form in accordance with the instructions indicated. This letter of authorization should be signed by a person with the proper authority to sign documents that are binding on the manufacturer. The Bidder shall include it in its bid, if so indicated in the BDS. 


\section{Affiliate Company Guarantee}

Name of Contract/Contract No.:

Name and address of Employer:

[together with successors and assigns].

We have been informed that [name of Contractor] (hereinafter called the "Contractor") is submitting an offer for the above-referenced Contract in response to your invitation, and that the conditions of your invitation require its offer to be supported by an affiliate company guarantee.

In consideration of you, the Employer, awarding the Contract to the Contractor, we [name of affiliated company] irrevocably and unconditionally guarantee to you, as a primary obligation, that (i) throughout the duration of the Contract, we will make available to the Contractor our financial, technical capacity, expertise and resources required for the Contractor's satisfactory performance of the Contract; and (ii) we are fully committed, along with the Contractor, to ensuring a satisfactory performance of the Contract.

If the Contractor fails to so perform its obligations and liabilities and comply with the Contract, we will indemnify the Employer against and from all damages, losses and expenses (including legal fees and expenses) which arise from any such failure for which the Contractor is liable to the Employer under the Contract.

This guarantee shall come into full force and effect when the Contract comes into full force and effect. If the Contract does not come into full force and effect within a year of the date of this guarantee, or if you demonstrate that you do not intend to enter into the Contract with the Contractor, this guarantee shall be void and ineffective. This guarantee shall continue in full force and effect until all the Contractor's obligations and liabilities under the Contract have been discharged, when this guarantee shall expire and shall be returned to us, and our liability hereunder shall be discharged absolutely.

This guarantee shall apply and be supplemental to the Contract as amended or varied by the Employer and the Contractor from time to time. We hereby authorize them to agree on any such amendment or variation, the due performance of which and compliance with which by the Contractor are likewise guaranteed hereunder. Our obligations and liabilities under this guarantee shall not be discharged by any allowance of time or other indulgence whatsoever by the Employer to the Contractor, or by any variation or suspension of the works to be executed under the Contract, or by any amendments to the Contract or to the constitution of the Contractor or the Employer, or by any other matters, whether with or without our knowledge or consent.

This guarantee shall be governed by the law of the same country (or other jurisdiction) that governs the Contract and any dispute under this guarantee shall be finally settled under the [Rules or Arbitration provided in the Contract]. We confirm that the benefit of this guarantee may be assigned subject only to the provisions for assignment of the Contract.

Signed by:

$$
\text { (signature) }
$$$$
\text { (name) }
$$

..............................

(position in parent/subsidiary company)
Signed by:

$$
\text { (signature) }
$$

(name)

...........................

(position in parent/subsidiary company)

Date:.

NOTE

If permitted in accordance with ITB 38.2 of the BDS, the Bidder shall provide the Affiliate Company Guarantee Form filled out and signed by each subsidiary, parent entity, or affiliate that the Bidder submits for consideration of the Employer in determining its qualifications. 


\section{Time Schedule}

To be used by Bidder when alternative Time for Completion is invited in ITB 13.2. 


\section{Functional Guarantee of the Proposed Facilities}

\section{Form FUNC}

The Bidder shall copy on the left column of the table below, the identification of each functional guarantee required in the Specification and stated by the Employer in EQC 1.3.4 of Section 3 (Evaluation and Qualification Criteria), and on the right column, provide the corresponding value for each functional guarantee of the proposed plant and equipment.

\begin{tabular}{|l|l|}
\multicolumn{1}{c|}{$\begin{array}{l}\text { Functional Guarantee } \\
\text { [as required by the Employer in Section 3] }\end{array}$} & Functional Guarantee Value Offered by the Bidder \\
\hline 1. & \\
\hline 2. & \\
\hline 3. & \\
\hline$\ldots$ & \\
\hline
\end{tabular}




\section{Bidder's Qualification}

To establish its qualifications to perform the contract in accordance with Section 3 (Evaluation and Qualification Criteria), the Bidder shall provide the following information requested in the corresponding Information Sheets. 
Form ELI - 1: Bidder's Information Sheet

\begin{tabular}{|c|c|c|c|}
\hline \multicolumn{4}{|c|}{ Bidder's Information } \\
\hline & & $\begin{array}{l}\text { Information of } \\
\text { the Bidder }\end{array}$ & $\begin{array}{l}\text { If the Bidder is a subsidiary or branch, } \\
\text { information of any parent company/companies }\end{array}$ \\
\hline \multirow[t]{2}{*}{ Name } & Full Legal Name & & \\
\hline & $\begin{array}{l}\text { Full Trading Name(s) } \\
\text { (if any) }\end{array}$ & & \\
\hline \multirow[t]{3}{*}{ Addresses } & $\begin{array}{l}\text { Registered } \\
\text { address(es) }\end{array}$ & & \\
\hline & Trading address(es) & & \\
\hline & $\begin{array}{l}\text { Postal address(es) } \\
\text { (if different from } \\
\text { trading address) }\end{array}$ & & \\
\hline \multicolumn{4}{|c|}{ Type of organization } \\
\hline \multicolumn{2}{|c|}{$\begin{array}{l}\text { Country of constitution/ } \\
\text { incorporation/registration }\end{array}$} & & \\
\hline \multicolumn{2}{|c|}{$\begin{array}{l}\text { Year of constitution/incorporation/ } \\
\text { registration }\end{array}$} & & \\
\hline \multicolumn{4}{|c|}{ Corporate or registration number } \\
\hline \multicolumn{2}{|c|}{$\begin{array}{l}\text { In case of a Joint Venture, legal } \\
\text { name of each partner }\end{array}$} & & \\
\hline \multicolumn{2}{|c|}{$\begin{array}{l}\text { Bidder's authorized representative } \\
\text { (name, address, telephone } \\
\text { number(s), fax number(s), and } \\
\text { e-mail address) }\end{array}$} & & \\
\hline \multicolumn{4}{|c|}{ Attached are copies of the following documents: } \\
\hline \multicolumn{4}{|r|}{$\begin{array}{l}\text { onstitution and company incorporation/registration } \\
\text { B } 4.1 \text { and ITB 4.2. }\end{array}$} \\
\hline \multicolumn{4}{|c|}{ 2. Authorization to represent the firm or Joint Venture named above, in accordance with ITB 22.2. } \\
\hline \multicolumn{4}{|c|}{$\begin{array}{l}\square \quad \text { 3. In case of a Joint venture, a letter of intent to form a Joint venture or Joint Venture agreement, in } \\
\text { accordance with ITB 4.1. }\end{array}$} \\
\hline \multicolumn{4}{|r|}{ ional documents not covered under 1 above required } \\
\hline
\end{tabular}


Form ELI - 2: Joint Venture Information Sheet

Each partner of the Joint Venture and Specialist Subcontractor must fill out this form separately.

\begin{tabular}{|c|c|c|c|}
\hline \multicolumn{2}{|c|}{ Bidder's legal name } & \multirow{3}{*}{$\begin{array}{l}\text { Information of Joint Venture } \\
\text { Partner or Specialist } \\
\text { Subcontractor }\end{array}$} & \multirow[b]{2}{*}{$\begin{array}{l}\text { If any Joint Venture Partner or } \\
\text { Specialist Subcontractor is a } \\
\text { subsidiary or branch, information of } \\
\text { any parent company/companies }\end{array}$} \\
\hline & & & \\
\hline \multirow[t]{2}{*}{ Names } & Full legal name(s) & & \\
\hline & $\begin{array}{l}\text { Full trading name(s) } \\
\text { (if any) }\end{array}$ & & \\
\hline \multirow[t]{3}{*}{ Addresses } & Registered address(es) & & \\
\hline & Trading address(es) & & \\
\hline & $\begin{array}{l}\text { Postal address (es) } \\
\text { (if different from } \\
\text { trading address) }\end{array}$ & & \\
\hline \multicolumn{2}{|c|}{ Type of organization } & & \\
\hline \multicolumn{2}{|c|}{$\begin{array}{l}\text { Country of constitution/ } \\
\text { incorporation/registration }\end{array}$} & & \\
\hline \multicolumn{2}{|c|}{$\begin{array}{l}\text { Year of constitution/incorporation/ } \\
\text { registration }\end{array}$} & & \\
\hline \multicolumn{2}{|c|}{ Corporate or registration number } & & \\
\hline \multicolumn{2}{|c|}{$\begin{array}{l}\text { Joint Venture Partner's or Specialist } \\
\text { Subcontractor's authorized } \\
\text { representative information } \\
\text { (name, address, telephone number(s), } \\
\text { fax number(s), and e-mail address) }\end{array}$} & & \\
\hline \multicolumn{4}{|c|}{ Attached are copies of the following documents: } \\
\hline \multicolumn{4}{|c|}{$\square$ 1. Articles of incorporation or constitution and company incorpora } \\
\hline \multicolumn{2}{|c|}{$\square$ 2. Authorization to represent the $\mathrm{fi}$} & m named above, in accordance & ith ITB 22.2 \\
\hline \multicolumn{4}{|c|}{$\begin{array}{l}\square \text { 3. In the case of a government-owned enterprise, documents establishing legal and financial autonomy and } \\
\text { compliance with commercial law, in accordance with ITB 4.5. }\end{array}$} \\
\hline
\end{tabular}

Subcontractors are those listed in Technical Proposal - Proposed Subcontractors and/or Manufacturers for Major Items of Plant and Services. 


\section{Form CON - 1: Historical Contract Nonperformance}

Each Bidder must fill out this form in accordance with Criteria 2.2.1 and 2.2.3 of Section 3 (Evaluation and Qualification Criteria) to describe any history of nonperforming contracts and pending litigation or arbitration formally commenced against it.

In case of a Joint Venture, each Joint Venture Partner must fill out this form separately and provide the Joint Venture Partner's name:

Joint Venture Partner:

\section{Table 1: History of Nonperforming Contracts}

\section{Choose one of the following:}

$\square$ No nonperforming contracts.

$\square$ Below is a description of nonperforming contracts involving the Bidder (or each Joint Venture partner if Bidder is a Joint Venture).

\begin{tabular}{|c|c|c|c|}
\hline Year & Description & $\begin{array}{l}\text { Amount of } \\
\text { Nonperformed Portion } \\
\text { of Contract } \\
\text { (\$ equivalent) }\end{array}$ & $\begin{array}{c}\text { Total Contract Amount } \\
\text { (\$ equivalent) }\end{array}$ \\
\hline $\begin{array}{l}\text { [insert } \\
\text { year] }\end{array}$ & $\begin{array}{l}\text { Contract Identification: [indicate complete } \\
\text { contract name/ number, and any other } \\
\text { identification] } \\
\text { Name of Employer: [insert full name] } \\
\text { Address of Employer: [insert street/city/ } \\
\text { country] } \\
\text { Reason(s) for nonperformance: [indicate } \\
\text { main reason(s)] }\end{array}$ & [insert amount] & [insert amount] \\
\hline
\end{tabular}




\section{Table 2: Pending Litigation and Arbitration}

\section{Choose one of the following:}

$\square$ No pending litigation, arbitration or any other material events impacting the net worth and/or liquidity of the bidder.

$\square$ Below is a description of all pending litigation, arbitration involving the Bidder or any material events impacting the net worth and/or liquidity of the bidder (or each Joint Venture partner if Bidder is a Joint Venture).

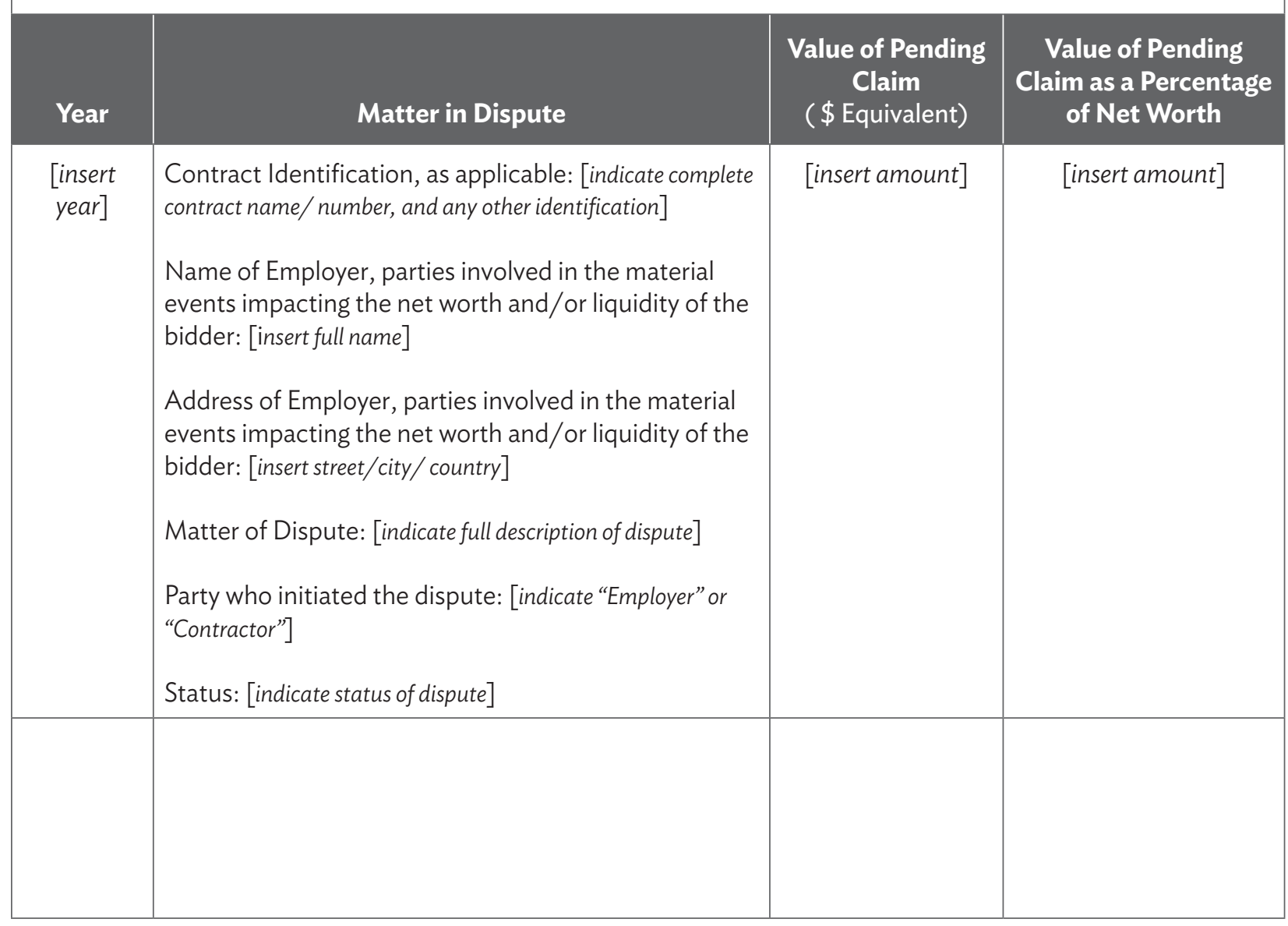

\section{NOTE}

Table 2 of this form shall only be included if Criterion 2.2.3 of Section 3 (Evaluation and Qualification Criteria) is applicable. 


\section{Form CON - 2: EHS Performance Declaration}

Each Bidder must fill out this form in accordance with Criterion 2.2.4 of Section 3 (Evaluation and Qualification Criteria).

In case of a Joint Venture, each Joint Venture Partner must fill out this form separately and provide the Joint Venture Partner's name:

Joint Venture Partner:

In case of a Specialist Subcontractors, each Specialist Subcontractor must fill out this form and provide the Specialist Subcontractor's name:

Specialist Subcontractor:

\section{Environmental, Health and Safety Performance Declaration} in accordance with Section 3 (Evaluation and Qualification Criteria)

- No suspension or termination of contract: An employer has not suspended or terminated a contract and/or called the performance security for a contract for reasons related to Environmental or Health and Safety performance since the date specified in Criterion 2.5 of Section 3 (Evaluation and Qualification Criteria).

- Declaration of suspension or termination of contract: The following contract(s) has/have been suspended or terminated and/or Performance Security called by an employer(s) for reasons related to Environmental or Health and Safety performance since the date specified in Criterion 2.5 of Section 3 (Evaluation and Qualification Criteria). Details are described below:

- Declaration of request for replacement of Key Environment, Health and Safety Personnel: The following contract(s) has/have experienced a request by the Employer to replace Environmental, Health and Safety Personnel for reasons related to Environmental or Health and Safety performance since the date specified in Criterion 2.5 of Section 3 (Evaluation and Qualification Criteria). Details are described below:

- Declaration of past fatality resulted from EHS issues on site: The following contract(s) has/have experienced a fatality resulted from EHS issues on site since the date specified in Criterion 2.5 of Section 3 (Evaluation and Qualification Criteria). Details are described below:

\begin{tabular}{|c|c|c|c|}
\hline Year & $\begin{array}{c}\text { Suspended or } \\
\text { terminated } \\
\text { portion of } \\
\text { contract }\end{array}$ & \multicolumn{1}{|c|}{ Contract Identification } & $\begin{array}{c}\text { Total Contract Amount } \\
\text { (current value, currency, } \\
\text { exchange rate and } \\
\text { \$ equivalent) }\end{array}$ \\
\hline [insert year] & $\begin{array}{c}\text { [insert amount and } \\
\text { percentage }]\end{array}$ & $\begin{array}{l}\text { Contract Identification: [indicate complete } \\
\text { contract name/number, and any other } \\
\text { identification] }\end{array}$ & $\begin{array}{l}\text { Nameunt] } \\
\text { [insert Employer: [insert full name }]\end{array}$ \\
& $\begin{array}{l}\text { Address of Employer: [insert street/city/country] } \\
\text { Reason(s) for suspension or termination: } \\
\text { [indicate main reason(s) } \text { e.g. discharge over } \\
\text { environmental limit, workers did not have required } \\
\text { health and safety permits to undertake high risk } \\
\text { work, work carried out was not adhered to approved } \\
\text { construction methodology and quality control plan }]\end{array}$ & \\
\hline
\end{tabular}




\begin{tabular}{|c|c|l|c|}
\hline [insert year] & $\begin{array}{c}\text { [insert amount and } \\
\text { percentage] }\end{array}$ & $\begin{array}{l}\text { Contract Identification: [indicate complete } \\
\text { contract name/number, and any other identification] } \\
\text { Name of Employer: [insert full name] }\end{array}$ & [insert amount] \\
& $\begin{array}{l}\text { Address of Employer: [insert street/city/country] } \\
\text { Reason(s) for suspension or termination: [indicate } \\
\text { main reason(s)] }\end{array}$ & $\ldots$ \\
\hline$\ldots$ & {$[$ [list all applicable contracts] } & \\
\hline
\end{tabular}

Performance Security called by an employer(s) for reasons related to EHS performance

\begin{tabular}{|c|l|c|}
\hline Year & \multicolumn{1}{|c|}{ Contract Identification } & $\begin{array}{c}\text { Total Contract Amount } \\
\text { (current value, currency, exchange } \\
\text { rate and \$ equivalent) }\end{array}$ \\
\hline [insert year] & $\begin{array}{l}\text { Contract Identification: [indicate complete contract name/ number, } \\
\text { and any other identification] }\end{array}$ & [insert amount] \\
& $\begin{array}{l}\text { Name of Employer: [insert full name] } \\
\text { Address of Employer: [insert street/city/country] }\end{array}$ & $\begin{array}{l}\text { Reason(s) for calling of performance security: [indicate main reason(s) } \\
\text { e.g. discharge over environmental limit, workers did not have required health and } \\
\text { safety permits to undertake high risk work, work carried out was not adhered to } \\
\text { approved construction methodology and quality control plan] }\end{array}$
\end{tabular}

Key EHS personnel replacement requested by the Employer for reasons related to EHS performance

\begin{tabular}{|c|c|c|}
\hline Year & Contract Identification and Reasons & $\begin{array}{l}\text { Personnel replacement action } \\
\text { and results }\end{array}$ \\
\hline [insert year] & $\begin{array}{l}\text { Contract Identification: [indicate complete contract name/ number, and } \\
\text { any other identification] } \\
\text { Name of Employer: [insert full name] } \\
\text { Address of Employer: [insert street/city/country] } \\
\text { Reason(s) for requesting for replacement: [indicate main reason(s)] }\end{array}$ & [insert description] \\
\hline \multicolumn{3}{|c|}{ Fatality due to EHS issues on Site } \\
\hline Year & Contract Identification & $\begin{array}{l}\text { Follow-on actions taken by the } \\
\text { contractor }\end{array}$ \\
\hline [insert year] & $\begin{array}{l}\text { Contract Identification: [indicate complete contract name/ number, } \\
\text { and any other identification] } \\
\text { Name of Employer: [insert full name] } \\
\text { Address of Employer: [insert street/city/country] } \\
\text { Description of fatality event: } \\
\text { Causation: }\end{array}$ & [insert description] \\
\hline
\end{tabular}




\section{Form FIN - 1: Historical Financial Performance}

Each Bidder must fill out this form.

In case of a Joint Venture, each Joint Venture Partner must fill out this form separately and provide the Joint Venture Partner's name:

Joint Venture Partner:

Financial Data for Previous 3 Years ${ }^{\mathrm{a}}$ [\$ Equivalent]

\begin{tabular}{|l|l|l}
\hline Year 1: & Year 2: & Year 3: \\
\hline
\end{tabular}

Information from Balance Sheet

\begin{tabular}{|l|l|l|l|}
\hline Total Assets (TA) & & & \\
\hline Total Liabilities (TL) & & & \\
\hline Net Worth = TA - TL & & & \\
\hline Current Assets (CA) & & & \\
\hline Current Liabilities (CL) & & & \\
\hline Working Capital = CA - CL & & $\begin{array}{l}\text { To be obtained for most recent year and carried } \\
\text { forward to FIN - 3 Line 1; in case of Joint } \\
\text { Ventures, to the corresponding Joint Venture } \\
\text { Partner's FIN - 3. }\end{array}$ \\
\hline Most Recent Working Capital & \\
\hline
\end{tabular}

Information from Income Statement

\begin{tabular}{|l|l|l|l|}
\hline Total Revenues & & & \\
\hline Profits Before Taxes & & & \\
\hline Profits After Taxes & & & \\
\hline
\end{tabular}

Attached are copies of financial statements (balance sheets including all related notes, and income statements) for the last 3 years, ${ }^{\text {b }}$ as indicated above, complying with the following conditions:

1. Unless otherwise required by Section 3 of the Bidding Documents, all such documents reflect the standalone financial situation of the legal entity or entities comprising the Bidder and not the Bidder's parent companies, subsidiaries, or affiliates. ${ }^{c}$

2. Historical financial statements must be audited by a certified accountant.

3. Historical financial statements must be complete, including all notes to the financial statements.

4. Historical financial statements must correspond to accounting periods already completed and audited (no statements for partial periods shall be requested or accepted).

a If the time period indicated under Criterion 2.3.1 of Section 3 (Evaluation and Qualification Criteria) is either 4 or 5 years, then the table columns above should be expanded accordingly.

b The time period stated here should be the same as the time period indicated under Criterion 2.3.1 of Section 3 (Evaluation and Qualification Criteria).

c When financial qualifications of Bidder's parent companies, subsidiaries, or affiliates are permitted in accordance with ITB 38.2 of Section 2, replace the text of condition 1 with "As required by Section 3 of the Bidding Documents, all such documents reflect the standalone financial situation of the legal entity or entities comprising the Bidder, as well as standalone financial situation of such Bidder's parent companies, subsidiaries, or affiliates which are proposed by the Bidder for Criteria 2.3 Financial Situation in Section 3 for consideration of the Employer in determining its qualifications." 


\section{Form FIN - 2: Average Annual Turnover}

Each Bidder must fill out this form.

The information supplied should be the Annual Turnover of the Bidder or each partner of a Joint Venture for the total certified payments received from the clients for contracts in progress or completed, converted to US dollars at the rate of exchange at the end of the period reported.

In case of a Joint Venture, each Joint Venture Partner must fill out this form separately and provide the Joint Venture Partner's name:

Joint Venture Partner:

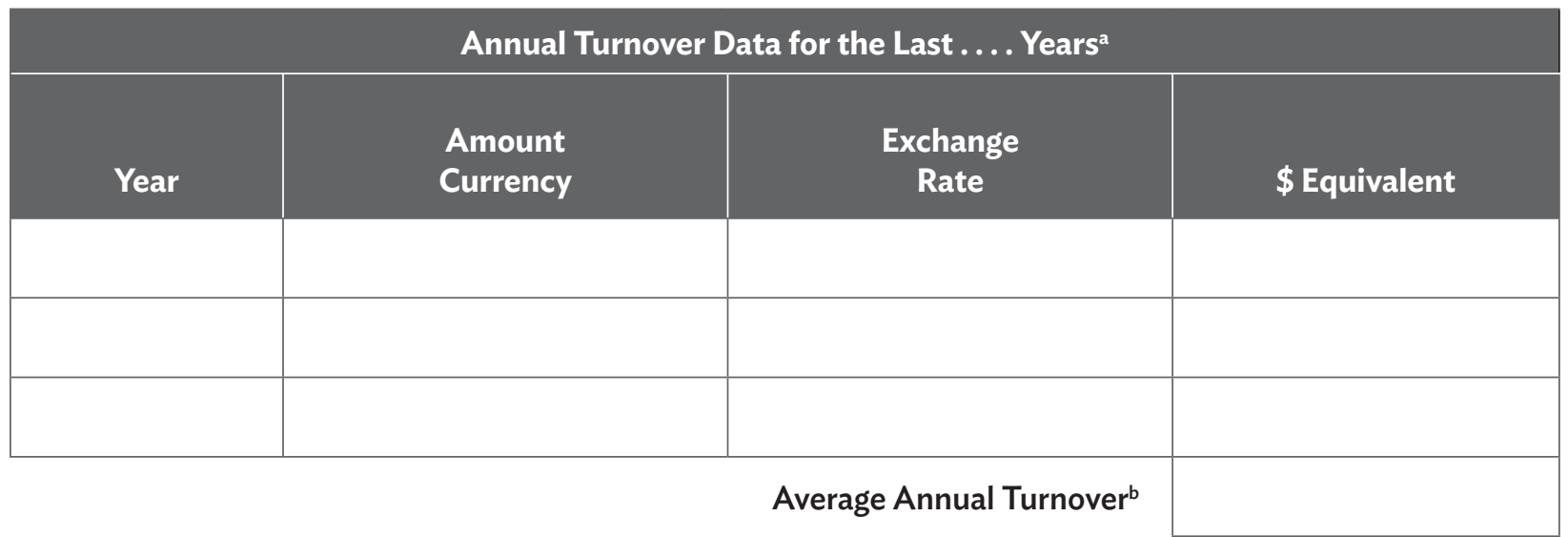

a The Employer should insert the period described in Criterion 2.3.2 of Section 3 (Evaluation and Qualification Criteria).

b To determine the average annual turnover, the Employer shall divide the sum of each year's annual turnover by the number of years for which such information was requested. 


\section{Form FIN - 3: Availability of Financial Resources}

Bidders must demonstrate sufficient financial resources, usually comprising of Working Capital supplemented by credit line statements or overdraft facilities and others to meet the Bidder's financial requirements for

(a) its current contract commitments, and

(b) the subject contract.

In case of a Joint Venture, each Joint Venture Partner must fill out this form separately and provide the Joint Venture Partner's name:

Joint Venture Partner:

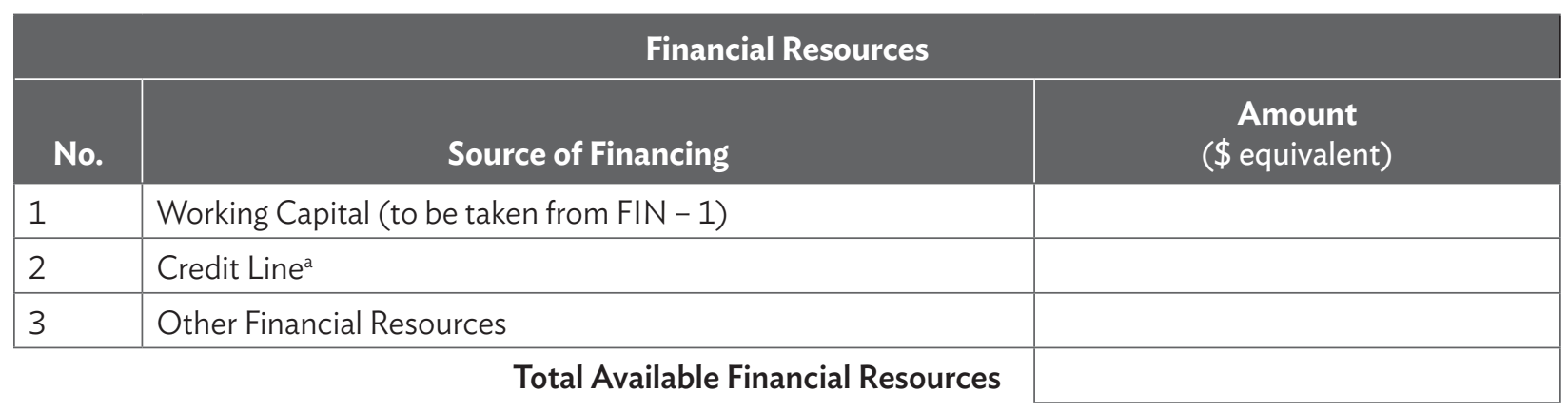

a To be substantiated by a letter from the bank issuing the line of credit.

\section{NOTE}

Further details on credit line requirements may be discussed and agreed upon during preparation of bidding document stage. 


\section{Form FIN - 4: Financial Requirements for Current Contract Commitments}

Bidders (or each Joint Venture partner) should provide information on their current commitments on all contracts that have been awarded, or for which a letter of intent or acceptance has been received, or for contracts approaching completion, but for which an unqualified, full completion certificate has yet to be issued.

In case of a Joint Venture, each Joint Venture Partner must fill out this form separately and provide the Joint Venture Partner's name:

Joint Venture Partner:

\begin{tabular}{|c|c|c|c|c|c|c|}
\hline \multicolumn{5}{|c|}{ Current Contract Commitments } \\
\hline No. & $\begin{array}{c}\text { Name of } \\
\text { Contract }\end{array}$ & $\begin{array}{c}\text { Employer's } \\
\text { Contact } \\
\text { (Address, } \\
\text { Tel, Fax) }\end{array}$ & $\begin{array}{c}\text { Contract } \\
\text { Completion } \\
\text { Date }\end{array}$ & $\begin{array}{c}\text { Outstanding } \\
\text { Contract } \\
\text { Value }(X))^{\mathbf{a}}\end{array}$ & $\begin{array}{c}\text { Remaining } \\
\text { Contract } \\
\text { Period in } \\
\text { Months }(Y)\end{array}$ & $\begin{array}{c}\text { Monthly Financial } \\
\text { Resources Requirement } \\
(X / Y)\end{array}$ \\
\hline 1 & & & & & & \\
\hline 2 & & & & & & \\
\hline 3 & & & & & \\
\hline 4
\end{tabular}

a Remaining outstanding contract values to be calculated from 28 days prior to the bid submission deadline ( $\$$ equivalent based on the foreign exchange rate as of the same date).

b Remaining contract period to be calculated from 28 days prior to bid submission deadline. 


\section{Form FIN - 5: Self-Assessment Tool for Bidder's Compliance to Financial Resources (Criterion 2.3.3 of Section 3)}

This form requires the same information submitted in Forms FIN - 3 and FIN - 4. All conditions of "Available Financial Resources Net of CCC $\geq$ Requirement for the Subject Contract" must be satisfied to qualify.

\section{Form FIN - 5A: For Single Entities}

\begin{tabular}{|c|c|c|c|c|c|}
\hline $\begin{array}{l}\text { For Single Entities: } \\
\text { (A) }\end{array}$ & $\begin{array}{l}\text { Total Available } \\
\text { Financial } \\
\text { Resources } \\
\text { from FIN - } 3 \\
\text { (B) }\end{array}$ & $\begin{array}{l}\text { Total Monthly Financial } \\
\text { Requirement for Current } \\
\text { Contract Commitments } \\
\text { (CCC) from FIN - } 4 \\
\text { (C) }\end{array}$ & $\begin{array}{l}\text { Available } \\
\text { Financial } \\
\text { Resources } \\
\text { Net of CCC } \\
\text { D = (B - C) }\end{array}$ & \begin{tabular}{|} 
Requirement \\
for the Subject \\
Contract \\
(E)
\end{tabular} & $\begin{array}{l}\text { Results: } \\
\text { Yes or No } \\
{[D \text { must be greate }} \\
\text { than or equal to } E] \\
\text { (F) }\end{array}$ \\
\hline$\overline{(\text { Name of Bidder) }}$ & & & & $\ldots \ldots{ }^{a}$ & \\
\hline
\end{tabular}

\section{Form FIN - 5B: For Joint Ventures}

\begin{tabular}{|c|c|c|c|c|c|}
\hline $\begin{array}{l}\text { For Joint Ventures: } \\
\text { (A) }\end{array}$ & $\begin{array}{l}\text { Total Available } \\
\text { Financial } \\
\text { Resources } \\
\text { from FIN - } 3 \\
\text { (B) }\end{array}$ & $\begin{array}{l}\text { Total Monthly Financial } \\
\text { Requirement for Current } \\
\text { Contract Commitments } \\
\text { (CCC) from FIN - } 4 \\
\text { (C) }\end{array}$ & $\begin{array}{l}\text { Available } \\
\text { Financial } \\
\text { Resources } \\
\text { Net of CCC } \\
D=(B-C)\end{array}$ & $\begin{array}{l}\text { Requirement } \\
\text { for the Subject } \\
\text { Contract } \\
\text { (E) }\end{array}$ & $\begin{array}{c}\text { Results: } \\
\text { Yes or No } \\
{[D \text { must be greater }} \\
\text { than or equal to } E] \\
\text { (F) }\end{array}$ \\
\hline \multicolumn{6}{|l|}{ One Partner: } \\
\hline \multicolumn{6}{|l|}{ (Name of Partner) } \\
\hline \multicolumn{6}{|l|}{ Each Partner: } \\
\hline \multicolumn{6}{|l|}{ (Name of Partner 1$)$} \\
\hline \multicolumn{6}{|l|}{ (Name of Partner 2) } \\
\hline \multicolumn{6}{|l|}{ (Name of Partner 3) } \\
\hline $\begin{array}{l}\text { All partners } \\
\text { combined }\end{array}$ & $\begin{array}{l}\sum D=\text { Sum of av } \\
\text { net of current } c c \\
\text { for all partners }\end{array}$ & $\begin{array}{l}\text { ailable financial resources } \\
\text { ontract commitments }\end{array}$ & $\Sigma \mathrm{D}=$ & & \\
\hline
\end{tabular}

a The Employer should insert here the total requirement for the Subject Contract (for both, single entity and all partners combined) as defined in Criterion 2.3.3 of Section 3.

b The Employer should insert here the required share for one partner as defined in Criterion 2.3.3 of Section 3.

c The Employer should insert here the required share for each partner as defined in Criterion 2.3.3 of Section 3.

\section{NOTE}

Form FIN - 5 is made available for use by the Bidder as a self-assessment tool, and by the Employer as an evaluation work sheet, to determine compliance with the financial resources requirement as stated in 2.3.3. Failure to submit Form FIN - 5 by the Bidder shall not lead to bid rejection. 


\section{Form EXP - 1: Contracts of Similar Size and Nature}

Fill out one (1) form per contract. Each contract shall be supported by documents such as Signed Contract Agreement, Taking-Over Certificate, Contract Completion Certificate, or Performance Certificate.

The exchange rate to be used to calculate the value of the contract for conversion to a specific currency shall be the selling rate of the Borrower's Central bank on the date of the contract.

\section{Contract of Similar Size and Nature}

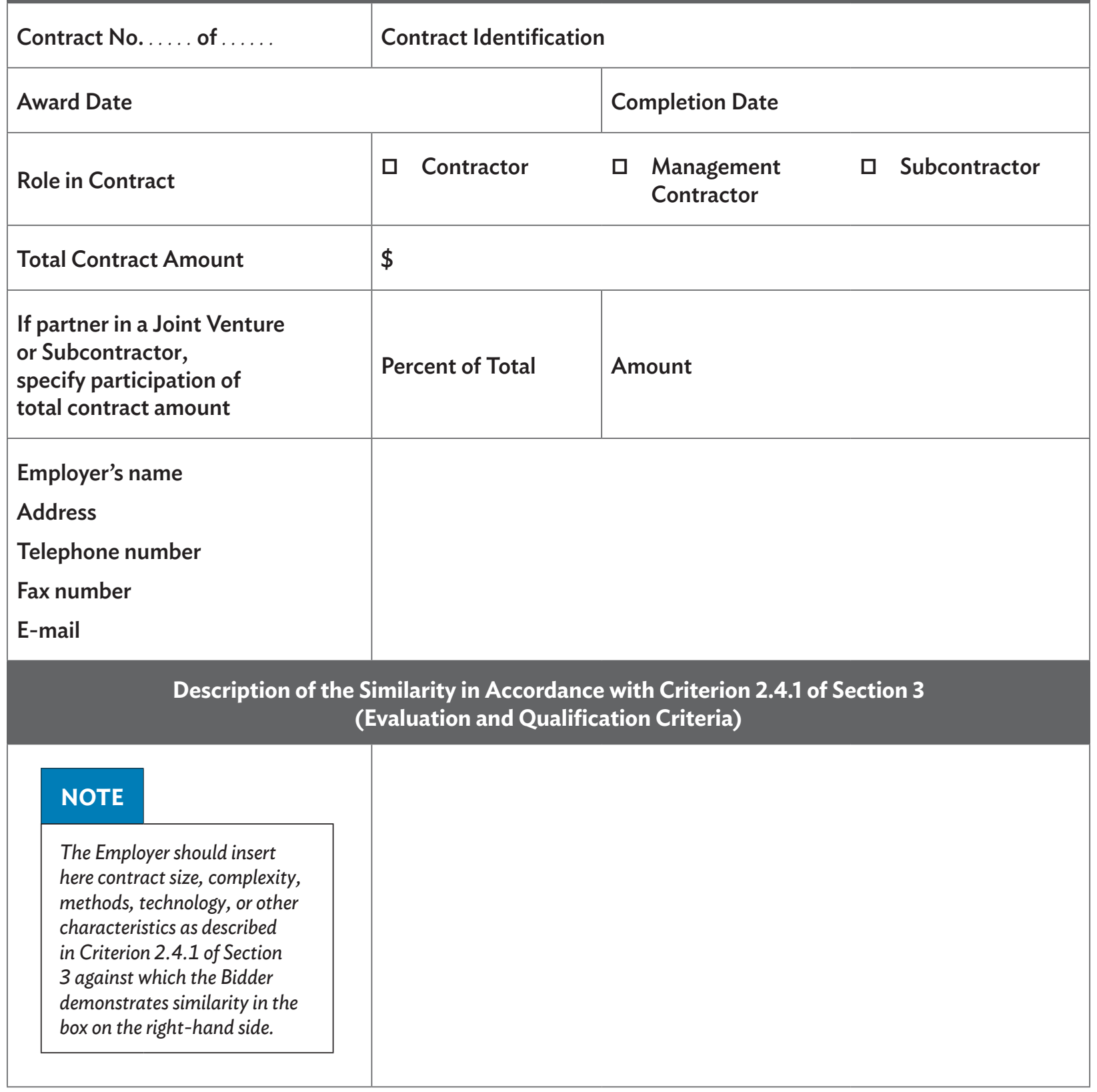




\section{Form EXP - 2: Experience in Key Activities}

Fill out one (1) form per contract. Each contract shall be supported by documents such as Signed Contract Agreement, Taking-Over Certificate or Contract Completion Certificate.

Each Bidder must fill out this form.

If complied by Specialist Subcontractors, each Specialist Subcontractor must fill out this form and provide the Specialist Subcontractor's name:

Specialist Subcontractor:

\section{Contract with Similar Key Activities}

\begin{tabular}{l|l} 
Contract No...... of ...... & Contract Identification
\end{tabular}

\begin{tabular}{|c|c|c|c|}
\hline \multicolumn{2}{|l|}{ Award Date } & \multicolumn{2}{|l|}{ Completion Date } \\
\hline Role in Contract & $\square$ Contractor & $\begin{array}{l}\text { Management } \\
\text { Contractor }\end{array}$ & ․ Subcontractor \\
\hline Total Contract Amount & $\$$ & & \\
\hline $\begin{array}{l}\text { If partner in a Joint Venture } \\
\text { or Subcontractor, } \\
\text { specify participation of } \\
\text { total contract amount }\end{array}$ & Percent of Total & Amount & \\
\hline \multicolumn{4}{|l|}{ Employer's name } \\
\hline \multicolumn{4}{|l|}{ Address } \\
\hline \multicolumn{4}{|l|}{ Telephone number } \\
\hline \multicolumn{4}{|l|}{ Fax number } \\
\hline \multicolumn{4}{|l|}{ E-mail } \\
\hline \multicolumn{4}{|c|}{$\begin{array}{c}\text { Description of the Key Activities in Accordance with Criterion 2.4.2 of Section } 3 \\
\text { (Evaluation and Qualification Criteria) }\end{array}$} \\
\hline \multicolumn{4}{|l|}{ NOTE } \\
\hline $\begin{array}{l}\text { The Employer should insert here } \\
\text { the major items of plant and } \\
\text { services listed under Criterion } \\
2.5 \text { of Section } 3 \text { against which } \\
\text { the Bidder demonstrates } \\
\text { similarity in the box on the } \\
\text { right-hand side. }\end{array}$ & & & \\
\hline
\end{tabular}




\section{Form EXP - 3: Specific Experience in Managing Environmental, Health and Safety Aspects}

Fill out one (1) form per contract.

Each Bidder must fill out this form.

In case of a Joint Venture, each Joint Venture Partner must fill out this form separately and provide the Joint Venture Partner's name:

Joint Venture Partner:

1. Key Requirement no 1 in accordance with Criterion 2.4.3 of Section 3:

\begin{tabular}{|c|c|c|c|c|}
\hline Contract Identification & & & & \\
\hline \multicolumn{5}{|l|}{ Award Date } \\
\hline \multicolumn{5}{|l|}{ Completion Date } \\
\hline Role in Contract & $\begin{array}{c}\text { Prime } \\
\text { Contractor } \\
\square\end{array}$ & $\begin{array}{l}\text { Partner } \\
\text { in JV } \\
\square\end{array}$ & $\begin{array}{c}\text { Management } \\
\text { Contractor } \\
\square\end{array}$ & $\begin{array}{c}\text { Subcontractor } \\
\square\end{array}$ \\
\hline Total Contract Amount & & & \multicolumn{2}{|l|}{$\$$} \\
\hline $\begin{array}{l}\text { Details of relevant } \\
\text { experience }\end{array}$ & & & & \\
\hline
\end{tabular}

2. Key Requirement no 2 in accordance with Criterion 2.4.3 of Section 3:

3. Key Requirement no 3 in accordance with Criterion 2.4.3 of Section 3: 


\section{Form EXP - 4: Environmental, Health and Safety Certification}

Please provide the following information:

Availability of the following valid ISO certification or internationally-recognized equivalent (equivalency to be demonstrated by the Bidder), and applicable to the worksite:

[Select the required certifications from below ${ }^{2}$ ]

- Quality management certificate ISO 9001

- Environmental management certificate ISO 14001

- Health and Safety management certificate ISO 45001

a Depending on the environmental, health and safety issues of the worksite and the type of competition planned (national or international), the list of required certifications may be restricted to those corresponding to the main issue of the worksite management, or removed altogether. 


\section{Form EXP - 5: Environmental, Health and Safety Documentation}

Please provide the following information:

Availability of in-house policies and procedures acceptable to the Employer for EHS management:

1. Existence of an Ethics Charter.

2. Existence of a system for monitoring compliance with EHS commitments for the Bidder's Subcontractors and all its partners.

3. Existence of official company procedures for the management of the following relevant points:

[Select 3-5 that apply for the worksite from below options - as per Section 2]

-EHS resources and facilities and EHS monitoring system;

- Project Areas management information (base camps, quarries, burrow pits, storage areas);

-Health and Safety on worksites policy and related guidance;

- Local recruitment and EHS trainings of local staff/subcontractors/local partners;

- Community stakeholder engagement practice;

-Traffic management practice;

- Hazardous products management practice;

-Waste management practice;

-Protection of water resources;

-Biodiversity protection practices;

- Site rehabilitation and revegetation practice;

-Local cultural heritage protection practice;

-Erosion and sedimentation practices;

-Control of infectious and communicable diseases (HIV/AIDS, malaria, COVID-19 etc) 


\section{Form EXP - 6: Environmental, Health and Safety Dedicated Personnel}

Please provide CV [Form PER-2] of the in-house personnel of the main contractor/Joint Venture partners for the EHS positions specified in Section 6 (Employer's Requirements):

[For example]

-Environmental Specialist

-Health and Safety Specialist 


\section{Form EXP - 7: Subcontractors}

Fill out one (1) form per contract.

\section{Contract for the Major Items}

\begin{tabular}{l|l} 
Contract No..... of ..... & Contract Identification
\end{tabular}

\begin{tabular}{|c|c|c|c|c|}
\hline \multicolumn{2}{|l|}{ Award Date } & \multicolumn{3}{|l|}{ Completion Date } \\
\hline Role in Contract & $\square$ Contractor & $\begin{array}{l}\text { Management } \\
\text { Contractor }\end{array}$ & $\square$ & Subcontractor \\
\hline Total Contract Amount & \multicolumn{4}{|l|}{$\$$} \\
\hline $\begin{array}{l}\text { If partner in a Joint Venture } \\
\text { or Subcontractor, } \\
\text { specify participation of } \\
\text { total contract amount }\end{array}$ & Percent of Total & Amount & & \\
\hline \multicolumn{5}{|l|}{$\begin{array}{l}\text { Employer's name } \\
\text { Address } \\
\text { Telephone number } \\
\text { Fax number } \\
\text { E-mail }\end{array}$} \\
\hline \multicolumn{5}{|c|}{$\begin{array}{c}\text { Description of the Major Items in Accordance with Criterion } 2.5 \text { of Section } 3 \\
\text { (Evaluation and Qualification Criteria) }\end{array}$} \\
\hline \multicolumn{5}{|l|}{ NOTE } \\
\hline $\begin{array}{l}\text { The Employer should insert } \\
\text { here the highly specialized } \\
\text { construction activities listed } \\
\text { under Criterion } 2.4 .2 \text { of Section } \\
3 \text { against which the Bidder } \\
\text { demonstrates similarity in the } \\
\text { box on the right-hand side. }\end{array}$ & & & & \\
\hline
\end{tabular}




\section{Section 5: Eligible Countries}

This section contains the list of eligible countries. Please choose one of the following cases and follow the instructions as appropriate.

\section{NOTES}

For Contracts to be financed by loans/grants from

1. OCR without cofinancing resources:

Unless a waiver of ADB member procurement eligibility restrictions was approved by the ADB Board of Directors, please insert the most recent list of ADB members obtainable from www.adb. org/about/members

EXCEPTION: If any other contract under the project is financed by cofinancing resources that are administered by ADB (other than those listed in para. 2 below), then please state "No nationality restrictions apply, other than any restrictions arising from ITB 4.8."

2. Regular loan from OCR with cofinancing resources from any one of the following funds:

(i) Asian Clean Energy Fund,

(ii) Japan Fund for Poverty Reduction,

(iii) Investment Climate Facilitation Fund,

(iv) Japan Fund for the Joint Credit Mechanism, and

(v) e-Asia and Knowledge Partnership Fund,

Unless a waiver of ADB member procurement eligibility restrictions was approved by the ADB Board of Directors, please insert the most recent list of ADB members obtainable from www.adb. org/about/members

3. Concessional loan from OCR with cofinancing resources from any one of the following funds:

(i) Asian Clean Energy Fund,

(ii) Japan Fund for Poverty Reduction,

(iii) Japan Fund for Public Policy Training,

(iv) Japan Fund for Information and Communication Technology,

(v) Investment Climate Facilitation Fund, and

(vi) e-Asia and Knowledge Partnership Fund,

Unless a waiver of ADB member procurement eligibility restrictions was approved by the ADB Board of Directors, please insert the most recent list of ADB members obtainable from www.adb.org/about/members

4. Regular loan from OCR with cofinancing resources other than those listed in para. 2 above:

Please state "No nationality restrictions apply, other than any restrictions arising from ITB 4.8."

5. Concessional loan from $\mathrm{OCR}$ with cofinancing resources other than those listed in para. 3 above:

Please state "No nationality restrictions apply, other than any restrictions arising from ITB 4.8."

\section{ADF without cofinancing resources:}

Unless a waiver of ADB member procurement eligibility restrictions was approved by the ADB Board of Directors, please insert the most recent list of $A D B$ members that have contributed to $A D F$ resources, and all $A D B$ developing member countries. 
EXCEPTION: If any other contract under the project is financed by cofinancing resources that are administered by ADB (other than those listed in para. 7 below), then please state "No nationality restrictions apply, other than any restrictions arising from ITB 4.8."

\section{ADF with cofinancing resources from any one of the following funds:}

(i) Asian Clean Energy Fund,

(ii) Japan Fund for Poverty Reduction,

(iii) Japan Fund for Public Policy Training,

(iv) Japan Fund for Information and Communication Technology,

(v) Investment Climate Facilitation Fund, and

(vi) e-Asia and Knowledge Partnership Fund,

Unless a waiver of ADB member procurement eligibility restrictions was approved by the ADB Board of Directors, please insert the most recent list of $A D B$ members that have contributed to ADF resources, and all ADB developing member countries.

8. ADF with cofinancing resources other than those listed in para. 6 above:

Please state "No nationality restrictions apply, other than any restrictions arising from ITB 4.8." 


\section{Section 6: Employer's Requirements}

This section contains the Scope, the Specifications, the Drawings, and Supplementary Information that describe the Facilities and Forms to be used during the implementation of the contract, as well as Personnel and Equipment Requirements. This section should not contain commercial or contract conditions that are stipulated in other parts of the Bidding Document.

In a design, supply, and installation approach, the design is to be done by the Contractor. No detailed technical specification as normally practiced is developed at the pre-bid stage. However, the Employer does and must know what it wants and must communicate its needs to the Bidders. Hence, this section on Employer's Requirements replaces the usual Technical Specifications of a more traditional approach.

To enable Bidders to submit responsive bids and, subsequently, for the bids received to be evaluated in an equitable manner, the Employer must make its requirements clear and precise. The Employer's requirements must therefore, specify the exact requirements of the completed Facilities. Where the performance of the completed Facilities could be measured in quantitative terms, such as production output of a manufacturing plant or maximum generating capacity of a power station, the Employer's Requirements should not only clearly specify the desired output and/or capacity but also the upper and lower acceptable limits of deviation from the desired capacity and how such deviations (if any) will be evaluated. It will also be necessary to specify the tests to be carried out upon completion of the Facilities to verify compliance with the specified requirements. The Employer's Requirements should also clearly list the associated or incidental services and goods that must be supplied by the Contractor. For example, the Contractor may be required to train the Employer's personnel and to supply consumable or spare parts as listed in a schedule.

While this section of the Bidding Document should endeavor to define the Employer's Requirements as precisely as possible, care must be taken to avoid over specifying details to the extent that the flexibility and potential benefits associated with a design, supply, and installation contract are seriously eroded or threatened. This section on Employer's Requirements should, therefore, be carefully prepared on behalf of the Employer by suitably qualified engineers who are familiar with the requirements and with the technical aspect of the required Facilities.

For an ADB-financed design, supply, and installation contract to be procured through open competitive bidding procedures, the Employer's Requirements must be drawn up to permit the widest possible competition and, at the same time, present a clear statement of the required standards of workmanship, materials, and performance of the Facilities. Only if this is done will the objectives of economy and efficiency, fairness, and transparency in procurement be realized, responsiveness of bids be ensured, and the subsequent task of bid evaluation facilitated. The Employer's Requirements should stipulate that all goods and materials to be incorporated in the Facilities are new, unused, of the most recent or current models, and should incorporate the latest improvements in design and materials. 


\section{Table of Contents}

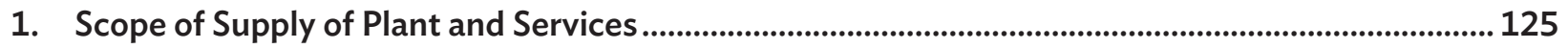

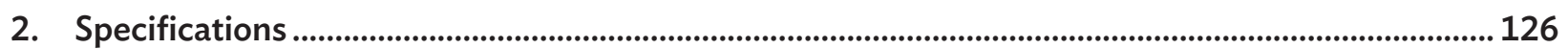

3. Environmental, Health and Safety Management Requirement..............................................................127

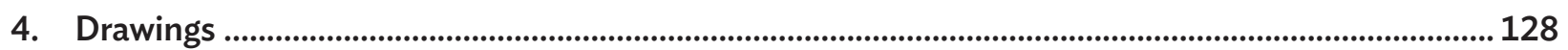

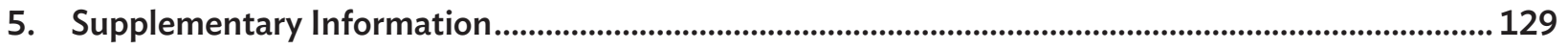

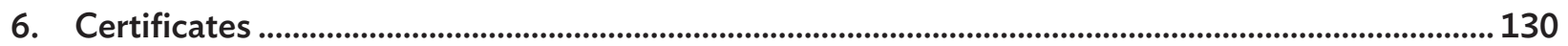

6.1 Form of Completion Certificate

6.2 Form of Operational Acceptance Certificate ......................................................................................... 132

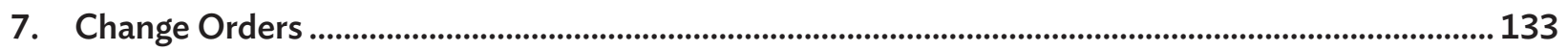

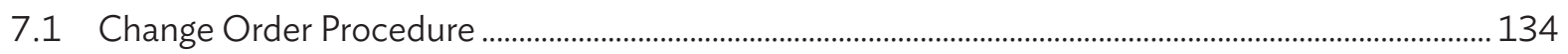

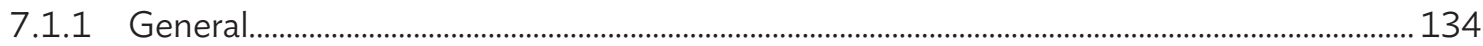

7.1.2 Change Order Log ........................................................................................................................... 134

7.1.3 References for Changes..................................................................................................... 134

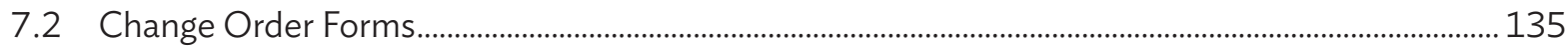

7.2.1 Request for Change Proposal Form ................................................................................................. 135

7.2.2 Estimate for Change Proposal Form ......................................................................................... 137

7.2.3 Acceptance of Estimate Form.................................................................................................... 138

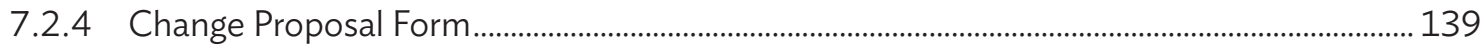

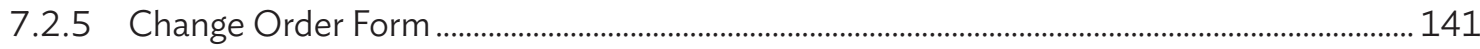

7.2.6 Pending Agreement Change Order Form ................................................................................. 142

7.2.7 Application for Change Proposal Form ......................................................................................... 143

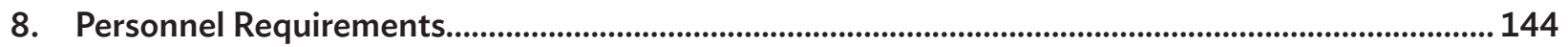

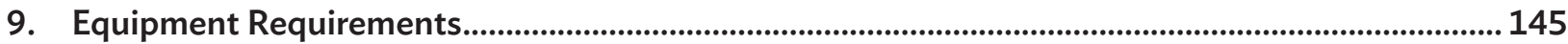




\section{Scope of Supply of Plant and Services}




\section{Specifications}

\section{NOTE}

Care must be taken when drafting the employer's requirements to ensure that the requirements are not restrictive. Recognized international standards should be used as much as possible when describing goods, materials, and workmanship. Where other particular standards are specified, whether national standards of the borrower's country or other standards, it should be stated that goods, materials, and workmanship meeting other authoritative standards and which promise to ensure equal or higher quality than the standards specified, will also be acceptable. Any mention of a specific brand name of a product should always be qualified with the terms "or equivalent." 


\section{Environmental, Health and Safety Management Requirement}

\section{NOTE}

The Employer's team preparing the EHS requirements should include a suitably qualified Environmental, Health and Safety specialist/s as determined by the EMP. The Employer should attach or refer to the Employer's environmental, health and safety policies that will apply to the project if available.

Based on the EIA undertaken for the project and this specific contract, the Employer shall provide key EHS risks and impacts and expectations on contractors to manage the risks and impacts. This may include as appropriate, but not limited to a summary of: key expectations in managing labor and working conditions, protection of the environment, health and safety and security of the site, community health and safety, management of safety of hazardous materials, resource efficiency and pollution prevention and management, biodiversity conservation and sustainable management of living natural resources, etc. Any summary (key) information provided here shall not be inconsistent with the more detailed requirements in the bidding document.

The Employer should highlight the requirement of a Site Specific Environmental/ Health and Safety Management Plan (SSEMP/SSHSMP) to be prepared based on the outline Environmental Health and Safety Management Plan (EHSMP) submitted as part of the Contractor's technical proposal. The SSEMP/SSHSMP shall be submitted within the contractual timeline (e.g. 28 days) outlined in the Contract Conditions. The Engineer/Project Manager shall endeavor to issue no-objection of the SSEMP/SSHSMP within a prescribed period (e.g.10 days) upon receipt of the SSEMP/SSHSMP, if the EHS requirements for the plan is met. No physical works shall commence on site prior to the confirmation of no objection of the SSEMP/SSHSMP has been obtained from the Engineer as per Contract Conditions.

Minimum Content of Requirements

In preparing detailed specifications for requirements, the specialists should refer to and consider:

- project reports e.g. EIA/EMP

- consent/permit conditions

- required standards including ADB Safeguard Policy Statement and related EHS Guidelines

- relevant international conventions or treaties etc., national legal and/or regulatory requirements and standards (where these represent higher standards than the ADB Guidelines)

- relevant international standards e.g. WHO Guidelines for Safe Use of Pesticides

- relevant sector standards e.g. EU Council Directive 91/271/EEC Concerning Urban Waste Water Treatment

- grievance redress mechanism including types of grievances to be recorded and how to protect confidentiality

The detail specification for EHS should, to the extent possible, describe the intended outcome rather than the method of working.

The EHS requirements should be prepared in manner that does not conflict with the relevant General Conditions of Contract (and the corresponding Particular Conditions if any) and other parts of the specifications.

Payment for EHS Requirements

The Employer's environmental, health and safety and procurement specialists should consider how the Contractor will cost the delivery of these requirements. In the majority of cases, the payment for the delivery of these requirements shall be a subsidiary obligation of the Contractor covered under the prices quoted for other Bill of Quantity items. For example, normally the cost of implementing work place safe systems of work, including the measures necessary for ensuring traffic and road safety, shall be covered by the Bidder's rates for the relevant works. Alternatively, provisional sums could be set aside for discrete activities for example to encourage the contractor to deliver additional environmental, health and safety outcomes beyond the requirement of the Contract. 


\section{Drawings}

\section{NOTE}

For a design, supply, and installation contract, no detail drawings would be available at the pre-bid stage. It would, however, be useful to include such conceptual drawings as are appropriate to supplement or help explain the general concept of the Employer's needs. 


\section{Supplementary Information}

\section{NOTE}

[The Employer is required to include local regulations and guidance specific to COVID-19 prevention and controls, and worksite safety measures requirements that are deemed applicable to the contract, as well as the applicable international good practices on Health and Safety for the contract as Supplementary Information under Section 6 - Employer's Requirements.

The Employer should attach the Environmental Impact Assessment ("EIA") and the Environmental Management Plan ("EMP”) as Supplementary Information in the Employer's Requirements. 


\section{Certificates}




\subsection{Form of Completion Certificate}

Contract: [insert name of contract and contract identification details]

Date:

Certificate No.:

To: [insert name and address of contractor]

Dear Ladies and/or Gentlemen,

Pursuant to GCC Clause 24 (Completion of the Facilities) of the General Conditions of the Contract entered into between yourselves and the Employer dated [insert date], relating to the [brief description of the Facilities], we hereby notify you that the following part(s) of the Facilities was (were) complete on the date specified below, and that, in accordance with the terms of the Contract, the Employer hereby takes over the said part(s) of the Facilities, together with the responsibility for care and custody and the risk of loss thereof on the date mentioned below.

1. Description of the Facilities or part thereof: [description]

2. Date of Completion: [date]

However, you are required to complete the outstanding items listed in the attachment hereto as soon as practicable.

This letter does not relieve you of your obligation to complete the execution of the Facilities in accordance with the Contract nor of your obligations during the Defect Liability Period.

Very truly yours,

[Signature]

Project Manager 


\subsection{Form of Operational Acceptance Certificate}

\section{Contract: [insert name of contract and contract identification details]}

Date:

Certificate No.:

To: [insert name and address of contractor]

Pursuant to GCC Subclause 25.3 (Operational Acceptance) of the General Conditions of the Contract entered into between yourselves and the Employer dated [date], relating to the [briefdescription of the facilities], we hereby notify you that the Functional Guarantees of the following part(s) of the Facilities were satisfactorily attained on the date specified below.

1. Description of the Facilities or part thereof: [description]

2. Date of Operational Acceptance: [date]

This letter does not relieve you of your obligation to complete the execution of the Facilities in accordance with the Contract nor of your obligations during the Defect Liability Period.

Very truly yours,

[Signature]

Project Manager 


\section{Change Orders}

\subsection{Change Order Procedure}

7.1.1 General

7.1.2 Change Order Log

7.1.3 References for Changes

\subsection{Change Order Forms}

7.2.1 Request for Change Proposal

7.2.2 Estimate for Change Proposal

7.2.3 Acceptance of Estimate

7.2.4 Change Proposal

7.2.5 Change Order

7.2.6 Pending Agreement Change Order

7.2.7 Application for Change Proposal 


\subsection{Change Order Procedure}

\subsubsection{General}

This section provides samples of procedures and forms for implementing changes in the Facilities during the performance of the Contract in accordance with GCC Clause 39 (Change in the Facilities) of the General Conditions.

\subsubsection{Change Order Log}

The Contractor shall keep an up-to-date Change Order Log to show the current status of Requests for Change and Changes authorized or pending. Entries of the Changes in the Change Order Log shall be made to ensure that the log is up-to-date. The Contractor shall attach a copy of the current Change Order Log in the monthly progress report to be submitted to the Employer.

\subsubsection{References for Changes}

(1) Request for Change as referred to in GCC Clause 39 shall be serially numbered CR-X-nnn.

(2) Estimate for Change Proposal as referred to in GCC Clause 39 shall be serially numbered CN-X-nnn.

(3) Acceptance of Estimate as referred to in GCC Clause 39 shall be serially numbered CA-X-nnn.

(4) Change Proposal as referred to in GCC Clause 39 shall be serially numbered CP-X-nnn.

(5) Change Order as referred to in GCC Clause 39 shall be serially numbered CO-X-nnn. Note:

(a) Requests for Change issued from the Employer's Home Office and the Site representatives of the Employer shall have the following respective references:

Home Office CR-H-nnn

Site CR-S-nnn

(b) The above number "nnn" is the same for Request for Change, Estimate for Change Proposal, Acceptance of Estimate, Change Proposal, and Change Order. 


\subsection{Change Order Forms}

\subsubsection{Request for Change Proposal Form}

[Employer's letterhead]

To: [Contractor's name and address]

Date:

Attention: [Name and title]

Contract Name: [Contract name]

Contract Number: [Contract number]

Dear Ladies and/or Gentlemen:

With reference to the captioned Contract, you are requested to prepare and submit a Change Proposal for the Change noted below in accordance with the following instructions within [number] days of the date of this letter [or on or before (date)].

1. Title of Change: [Title]

2. Change Request No./Rev.: [Number]

3. Originator of Change:

Employer: [Name]

Contractor: (by Application for Change Proposal No. [Number Refer to Annex 6.2.7])

4. Brief Description of Change: [Description]

5. Facilities and/or Item No. of equipment related to the requested Change: [Description]

6. Reference drawings and/or technical documents for the request of Change:

[Drawing No./Document No./Description]

7. Detailed conditions or special requirements on the requested Change: [Description]

8. General Terms and Conditions:

(a) Please submit your estimate showing what effect the requested Change will have on the Contract Price.

(b) Your estimate shall include your claim for the additional time, if any, for completing the requested Change.

(c) If you have any opinion that is critical to the adoption of the requested Change in connection with the conformability to the other provisions of the Contract or the safety of the Plant or Facilities, please inform us in your proposal of revised provisions. 
(d) Any increase or decrease in the work of the Contractor relating to the services of its personnel shall be calculated.

(e) You shall not proceed with the execution of the work for the requested Change until we have accepted and confirmed the amount and nature in writing.

[Employer's Name]

[Signature]

[Name of signatory]

[Title of signatory] 


\subsubsection{Estimate for Change Proposal Form}

[Contractor's letterhead]

To: [Employer's name and address]

Date:

Attention: [Name and title]

Contract Name: [Contract name]

Contract Number: [Contract number]

Dear Ladies and/or Gentlemen:

With reference to your Request for Change Proposal, we are pleased to notify you of the approximate cost to prepare the below-referenced Change Proposal in accordance with GCC Subclause 39.2.1 of the General Conditions. We acknowledge that your agreement to the cost of preparing the Change Proposal, in accordance with GCC Subclause 39.2.2, is required before estimating the cost for change work.

1. Title of Change: [Title]

2. Change Request No./Rev.: [Number]

3. Brief Description of Change: [Description]

4. Scheduled Impact of Change: [Description]

5. Cost for Preparation of Change Proposal: [insert costs, which shall be in the currencies of the contract]

(a) Engineering

(Amount)

(i) Engineer hours (hrs) $x$ rate $/ \mathrm{hr}=$

(ii) Draftsperson hrs $x$ rate $/ \mathrm{hr}=$

Subtotal hrs

Total Engineering Cost

(b) Other Cost

$$
\text { Total Cost (a) + (b) }
$$

[Contractor's name]

[Signature]

[Name of signatory]

[Title of signatory] 


\subsubsection{Acceptance of Estimate Form}

[Employer'sletterhead]

To: [Contractor's name and address]

Date:

Attention: [Name and title]

Contract Name: [Contract name]

Contract Number: [Contract number]

Dear Ladies and/or Gentlemen:

We hereby accept your Estimate for Change Proposal and agree that you should proceed with the preparation of the Change Proposal.

1. Title of Change: [Title]

2. Change Request No./Rev.: [Request number/revision]

3. Estimate for Change Proposal No./Rev.: [Proposal number/revision]

4. Acceptance of Estimate No./Rev.: [Estimate number/revision]

5. Brief Description of Change: [Description]

6. Other Terms and Conditions: In the event that we decide not to order the Change accepted, you shall be entitled to compensation for the cost of preparing the Change Proposal described in your Estimate for Change Proposal mentioned in para. 3 above in accordance with GCC Clause 39 of the General Conditions.

[Employer's Name]

[Signature]

[Name of signatory]

[Title of signatory] 


\subsubsection{Change Proposal Form}

\section{[Contractor's letterhead]}

To: [Employer's name and address]

Date:

Attention: [Name and title]

Contract Name: [Contract name]

Contract Number: [Contract number]

Dear Ladies and/or Gentlemen:

In response to your Request for Change Proposal No. [Number], we hereby submit our proposal as follows:

1. Title of Change: [Name]

2. Change Proposal No./Rev.: [Proposal number/revision]

3. Originator of Change: Employer: [Name]/Contractor: [Name]

4. Brief Description of Change: [Description]

5. Reasons for Change: [Reason]

6. Facilities and/or Item No. of Equipment related to the requested Change: [Facilities]

7. Reference drawings and/or technical documents for the requested Change:

[Drawing/Document No./Description]

8. Estimate of increase/decrease to the Contract Price resulting from the Change Proposal:

Amount

[insert amounts in the currencies of the Contract]
(a) Direct material
(b) Major construction equipment
(c) Direct field labor (Total hrs)
(d) Subcontracts
(e) Indirect material and labor
(f) Site supervision 
(g) Head office technical staff salaries

\begin{tabular}{|c|c|}
\hline Process engineer & -_-_hrs@ \\
\hline Project engineer & _-_-_hrs@ \\
\hline Equipment engineer & -_-_hrs@ \\
\hline Procurement & -_-_hrs@ \\
\hline Draftsperson & -_-_hrs@ \\
\hline
\end{tabular}

Total ___-_ hrs

(h) Extraordinary costs (computer, travel, etc.)

(i) Fee for general administration, \% of Items

(j) Taxes and customs duties

Total lump sum cost of Change Proposal

[Sum of items (a) to (j)]

Cost to prepare Estimate for Change Proposal

[Amount payable if Change is not accepted]

9. Additional time for Completion required due to Change Proposal

10. Effect on the Functional Guarantees

11. Effect on the other terms and conditions of the Contract

12. Validity of this Proposal: within [Number] days after receipt of this Proposal by the Employer

13. Other terms and conditions of this Change Proposal:

(a) You are requested to notify us of your acceptance, comments, or rejection of this detailed Change Proposal within [Number] days from your receipt of this Proposal.

(b) The amount of any increase and/or decrease shall be taken into account in the adjustment of the Contract Price.

(c) Contractor's cost for preparation of this Change Proposal: [insert amount. This cost shall be reimbursed by the employer in case of employer's withdrawal or rejection of this Change Proposal without default of the contractor in accordance with GCC Clause 39 of the General Conditions.]

[Contractor's name]

[Signature]

[Name of signatory]

[Title of signatory] 


\subsubsection{Change Order Form}

[Employer's letterhead]

To: [Contractor's name and address]

Date:

Attention: [Name and title]

Contract Name: [Contract name]

Contract Number: [Contract number]

Dear Ladies and/or Gentlemen:

We approve the Change Order for the work specified in the Change Proposal (No. [number]), and agree to adjust the Contract Price, Time for Completion, and/or other conditions of the Contract in accordance with GCC Clause 39 of the General Conditions.

1. Title of Change: [Name]

2. Change Request No./Rev.: [Request number/revision]

3. Change Order No./Rev.: [Order number/revision]

4. Originator of Change: Employer: [Name]/Contractor: [Name]

5. Authorized Price: Ref. No.: [Number] Date: [Date]

Foreign currency portion [Amount] plus Local currency portion [Amount]

6. Adjustment of Time for Completion:
None
Increase [Number] days
Decrease [Number] days

7. Other effects, if any:

Authorized by:

Employer

Date:

Accepted by:

Contractor

Date: 


\subsubsection{Pending Agreement Change Order Form}

[Employer'sletterhead]

To: [Contractor's name and address]

Date:

Attention: [Name and title]

Contract Name: [Contract name]

Contract Number: [Contract number]

Dear Ladies and/or Gentlemen:

We instruct you to carry out the work in the Change Order detailed below in accordance with GCC Clause 39 of the General Conditions.

1. Title of Change: [Name]

2. Employer's Request for Change Proposal No./Rev.: [number/revision] Dated [Date]

3. Contractor's Change Proposal No./Rev.: [number/revision] Dated [Date]

4. Brief Description of Change: [Description]

5. Facilities and/or Item No. of equipment related to the requested Change: [Facilities]

6. Reference Drawings and/or technical documents for the requested Change: [Drawing/Document No./Description]

7. Adjustment of Time for Completion:

8. Other change in the Contract terms:

9. Other terms and conditions:

[Employer's name]

[Signature]

[Name of signatory]

[Title of signatory] 


\subsubsection{Application for Change Proposal Form}

[Contractor's letterhead]

To: [Employer's name and address]

Date:

Attention: [Name and title]

Contract Name: [Contract name]

Contract Number: [Contract number]

Dear Ladies and/or Gentlemen:

We hereby propose that the work mentioned below be treated as a Change in the Facilities.

1. Title of Change: [Name]

2. Application for Change Proposal No./Rev.: [Number/revision] Dated [Date]

3. Brief Description of Change: [Description]

4. Reasons for Change:

5. Order of Magnitude Estimation (amount in the currencies of the Contract): [Amount]

6. Scheduled Impact of Change:

7. Effect on Functional Guarantees, if any:

8. Appendix:

[Contractor's name]

[Signature]

[Name of signatory]

[Title of signatory] 


\section{Personnel Requirements}

Using Form PER - 1 and PER - 2 in Section 4 (Bidding Forms), the Bidder must demonstrate that it has personnel who meet the following requirements:

\begin{tabular}{|c|c|c|c|}
\hline No. & Position & $\begin{array}{c}\text { Total Work Experience } \\
\text { (years) }\end{array}$ & $\begin{array}{c}\text { Experience in Similar Work } \\
\text { (years) }\end{array}$ \\
\hline 1 & & & \\
\hline 2 & & & \\
\hline 3 & & & \\
\hline 4 & & & \\
\hline 5 & & & \\
\hline
\end{tabular}

\section{NOTES}

The managerial and technical competence of a contractor is largely related to key personnel on site. The extent to which the Bidder should demonstrate having staff with extensive experience should be limited to those requiring critical operational or technical skills. The personnel requirement should therefore refer to a limited number of such key personnel, for instance, the project or contract manager and those superintendents working under the project manager who will be responsible for major components (e.g., superintendents specializing in transmission lines, substations, turbines, wastewater treatment plant, or water treatment plant, as required for each particular project). Requirements should specify:

(a) the minimum number of years of experience in a similar position; and

(b) the minimum number of years of experience and/or number of comparable projects carried out in a specified number of preceding years.

The requirement of education and academic qualifications is normally unnecessary for such positions, as contractors often employ competent staff who have learned their profession "on the job" rather than through academic training. It is appropriate to specify that certain positions are filled by individuals who have held posts of comparable authority for, say, 3 years with the Bidder, so that key staff in executive site positions have sufficient knowledge of the Bidder's management, policy, procedures, and practices to act with confidence and authority within that framework.

Using Form EXP-6 in Section 4 (Bidding Forms), the Bidder must demonstrate that it has EHS personnel who meet the following requirements:

[Note: Insert in the following table, the minimum key EHS specialists required to execute the contract, taking into account the nature, scope, complexity and risks of the contract.]

Key Personnel as determined by the EMP and other safeguard management plans

\begin{tabular}{|c|l|l|l|l|} 
Item No. & Position/specialization & $\begin{array}{c}\text { Relevant academic } \\
\text { qualifications }\end{array}$ & $\begin{array}{c}\text { Minimum years of relevant } \\
\text { work experience }\end{array}$ & $\begin{array}{c}\text { Minimum time } \\
\text { on- site (\% FTE) }\end{array}$ \\
\hline 1 & & & & \\
\hline 2 & & & & \\
\hline
\end{tabular}




\section{Equipment Requirements}

Using Form EQU in Section 4 (Bidding Forms), the Bidder must demonstrate that it has the key equipment listed below:

\begin{tabular}{|c|c|c|}
\hline No. & Equipment Type and Characteristics & $\begin{array}{c}\text { Minimum Number } \\
\text { Required }\end{array}$ \\
\hline 1 & & \\
\hline 2 & & \\
\hline 3 & & \\
\hline 4 & & \\
\hline 5 & & \\
\hline
\end{tabular}

\section{NOTES}

The Employer should only specify bulky or specialized items that are critical for the type of project to be implemented, and which may be difficult for the contractor to obtain quickly. Examples may include items such as heavy lift cranes and piling barges.

An inventory of construction equipment represents a high capital cost overhead to a contractor. Consequently, not all competent potential Bidders will maintain an inventory of high-value items that are in suitable condition for major contracts. This is particularly so with management contractors, who undertake construction projects mainly by subcontracting. In most cases, Bidders can readily purchase, lease, or hire equipment; Examples may include items such as heavy lift cranes and piling barges, etc. Even in such cases, contractors may not own the specialized items of equipment, and may rely on Specialist Subcontractors or equipment-hire firms. The availability of such Subcontractors and of the specified equipment should be subject to verification prior to contract award. The terms of any lease or hire agreement for equipment should preferably include a provision that the equipment will remain on the site (or be vested in the Employer) in the event of default of the contractor, thereby ensuring more timely continuity of work by a replacement contractor. 


\section{Section 7: General Conditions of Contract}

These General Conditions of Contract (GCC) are derived from the former Standard Bidding Document for Supply and Installation of Plant and Equipment of the World Bank, which were based on the Model Form of International Contract for Process Plant Construction published by the Engineering Advancement Association of Japan (ENAA). The multilateral development banks participating in the procurement harmonization process gratefully acknowledge the contribution of ENAA to the advancement of good contracting practices by its borrowers. The GCC contain general clauses to be applied on all contracts. The GCC in this section, read in conjunction with the Special Conditions of Contract in Section 8 and other documents listed therein, should be a complete document expressing all the rights and obligations of the contracting parties. The General Conditions herein shall not be altered.

\section{Table of Clauses}

A. Contract and Interpretation.

1. Definitions

2. Contract Documents 151

3. Interpretation 151

4. Communications 153

5. Law and Language 153

6. Fraud and Corruption 154

B. Subject Matter of Contract 156

7. Scope of Facilities. 156

8. Time for Commencement and Completion 157

9. Contractor's Responsibilities 157

10. Employer's Responsibilities 


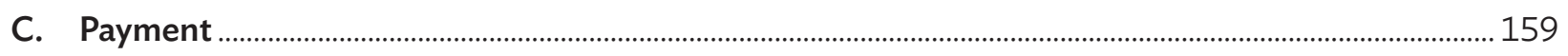

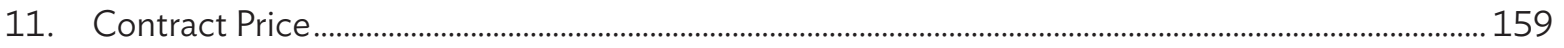

12. Terms of Payment

13. Securities ................................................................................................................................................ 160

14. Taxes and Duties............................................................................................................................................

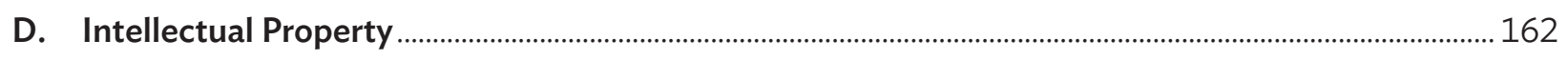

15. License/Use of Technical Information ....................................................................................................162

16. Confidential Information ..................................................................................................................................

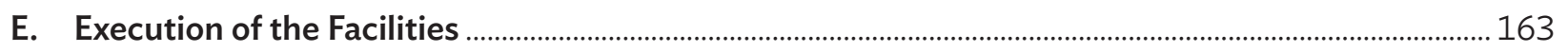

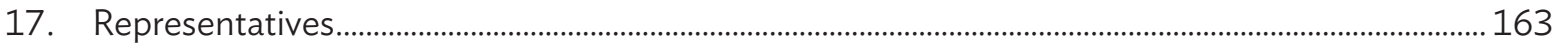

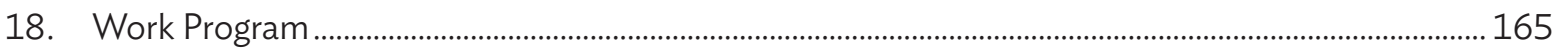

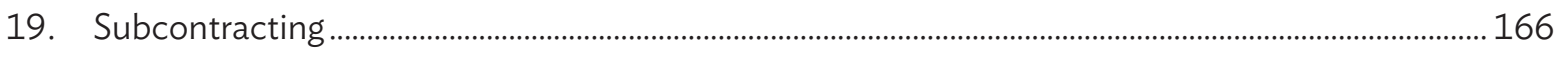

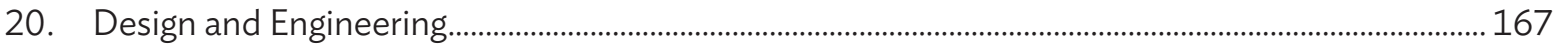

21. Procurement.....................................................................................................................................................169

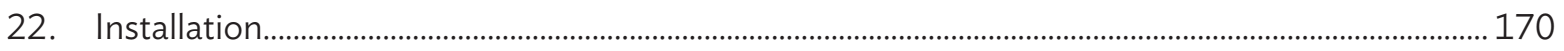

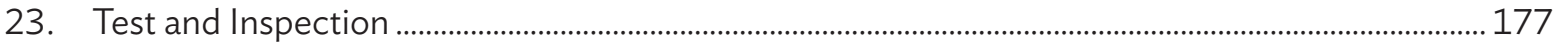

24. Completion of the Facilities......................................................................................................................... 178

25. Commissioning and Operational Acceptance ......................................................................................... 180

F. Guarantees and Liabilities............................................................................................................................... 183

26. Completion Time Guarantee........................................................................................................................... 183

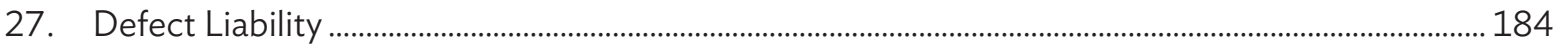

28. Functional Guarantees ..................................................................................................................................... 185

29. Patent Indemnity ........................................................................................................................................... 186

30. Limitation of Liability .................................................................................................................................... 187 


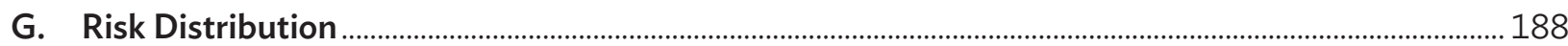

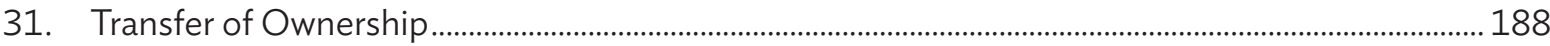

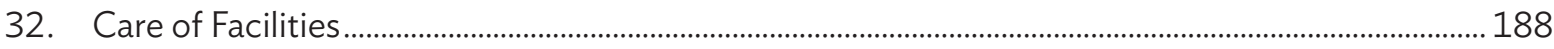

33. Loss of or Damage to Property; Accident or Injury to Workers; Indemnification ........................... 189

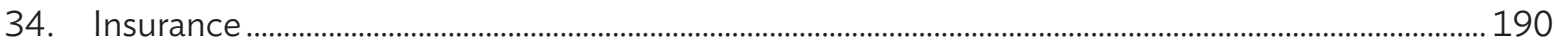

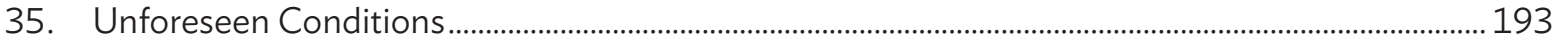

36. Change in Laws and Regulations ................................................................................................. 194

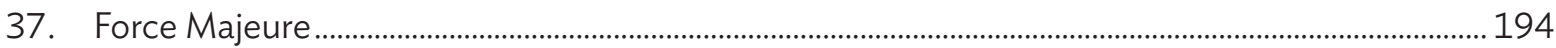

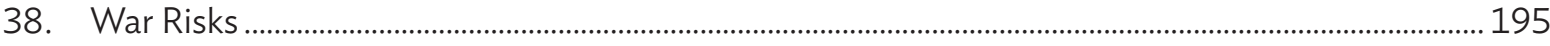

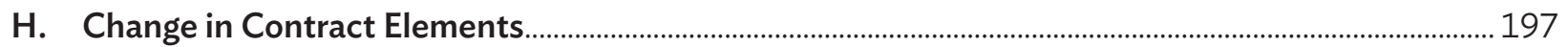

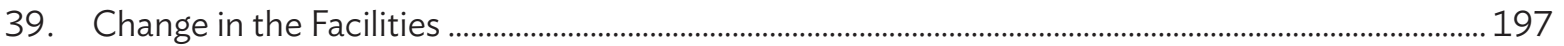

40. Extension of Time for Completion ............................................................................................................. 200

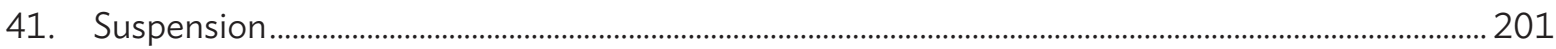

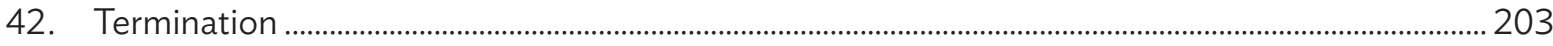

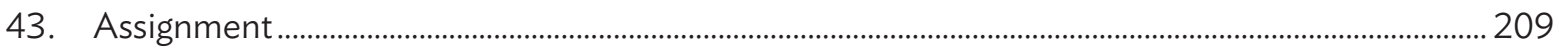

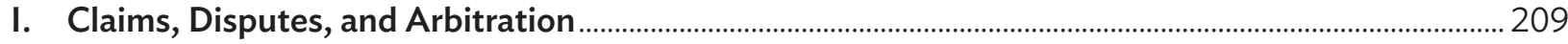

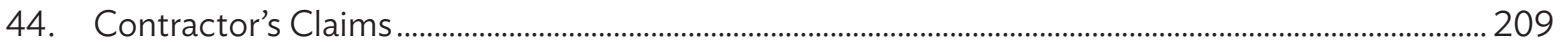

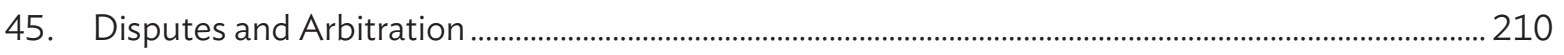




\section{A. Contract and Interpretation}

1. Definitions
1.1 The following words and expressions shall have the meanings hereby assigned them:

(a) "Contract" means the Contract Agreement entered into between the Employer and the Contractor, together with the Contract Documents referred to therein; they shall constitute the Contract, and the term "the Contract" shall in all such documents be construed accordingly.

(b) "Contract Documents" means the documents listed in Article 1.1 (Contract Documents) of the Contract Agreement (including any amendments thereto).

(c) "GCC" means the General Conditions of Contract.

(d) "SCC" means the Special Conditions of Contract.

(e) "day" means calendar day.

(f) "year" means 365 days.

(g) "month" means calendar month.

(h) "Party" means the Employer or the Contractor, as the context requires.

(i) "Employer" means the person named as such in the SCC and includes the legal successors or permitted assigns of the Employer.

(j) "Project Manager" means the person appointed by the Employer in the manner provided in GCC Subclause 17.1 (Project Manager) hereof and named as such in the SCC to perform the duties delegated by the Employer.

(k) "Contractor" means the person(s) named as Contractor in the Contract Agreement, and includes the legal successors or permitted assigns of the Contractor.

(I) "Contractor's Representative" means any person nominated by the Contractor and approved by the Employer in the manner provided in GCC Subclause 17.2 (Contractor's Representative and Construction Manager) hereof to perform the duties delegated by the Contractor.

(m) "Construction Manager" means the person appointed by the Contractor's Representative in the manner provided in GCC Subclause 17.2.4.

(n) "Subcontractor," including manufacturers, means any person to whom execution of any part of the Facilities, including preparation of any design or supply of any Plant, is subcontracted directly or indirectly by the Contractor, and includes its legal successors or permitted assigns. 
(o) "Dispute Board" means the person or persons named as such in the SCC appointed by agreement between the Employer and the Contractor to make a decision on or to settle any dispute or difference between the Employer and the Contractor referred to him or her by the parties pursuant to GCC Subclause 45.1 (Dispute Board) hereof.

(p) "The Bank" means the financing institution named in the SCC.

(q) "Contract Price" means the sum specified in Article 2.1 (Contract Price) of the Contract Agreement, subject to such additions and adjustments thereto or deductions therefrom, as may be made pursuant to the Contract.

(r) "Facilities" means the Plant to be supplied and installed, as well as all the Installation Services to be carried out by the Contractor under the Contract.

(s) "Plant" means permanent plant, equipment, machinery, apparatus, articles, and things of all kinds to be provided and incorporated in the Facilities by the Contractor under the Contract (including the spare parts to be supplied by the Contractor under GCC Subclause 7.3 hereof), but does not include Contractor's Equipment.

(t) "Installation Services" means all those services ancillary to the supply of the Plant for the Facilities, to be provided by the Contractor under the Contract, such as transportation and provision of marine or other similar insurance, inspection, expediting, site preparation works (including the provision and use of Contractor's Equipment and the supply of all construction materials required), installation, testing, pre-commissioning, commissioning, operations, maintenance, the provision of operations and maintenance manuals, training, etc. as the case may require.

(u) "Contractor's Equipment" means all facilities, equipment, machinery, tools, apparatus, appliances, or things of every kind required in or for installation, completion, and maintenance of Facilities that are to be provided by the Contractor, but does not include Plant, or other things intended to form or forming part of the Facilities.

(v) "Country of Origin" means the countries and territories eligible under the rules of the Bank as further elaborated in the SCC.

(w) "Site" means the land and other places upon which the Facilities are to be installed, and such other land or places as may be specified in the Contract as forming part of the Site.

(x) "Effective Date" means the date of fulfillment of all conditions stated in Article 3 (Effective Date) of the Contract Agreement, upon which the period until the Time for Completion shall be counted from.

(y) "Time for Completion" means the time within which Completion of the Facilities as a whole (or of a part of the Facilities where a separate Time for Completion of such part has been prescribed) is to be attained, as referred to in GCC Clause 8 and in accordance with the relevant provisions of the Contract. 
(z) "Completion" means that the Facilities (or a specific part thereof where specific parts are specified in the Contract) have been completed operationally and structurally and put in a tight and clean condition, that all work in respect of Pre-commissioning of the Facilities or such specific part thereof has been completed, and that the Facilities or specific part thereof are ready for Commissioning as provided in GCC Clause 24 (Completion) hereof.

(aa) "Pre-commissioning" means the testing, checking, and other requirements specified in the Employer's Requirements that are to be carried out by the Contractor in preparation for Commissioning as provided in GCC Clause 24 (Completion) hereof.

(bb) "Commissioning" means operation of the Facilities or any part thereof by the Contractor following Completion, which operation is to be carried out by the Contractor as provided in GCC Subclause 25.1 (Commissioning) hereof, for the purpose of carrying out Guarantee Test(s).

(cc) "Guarantee Test(s)" means the test(s) specified in the Employer's Requirements to be carried out to ascertain whether the Facilities or a specified part thereof is able to attain the Functional Guarantees specified in the Appendix (Functional Guarantees) to the Contract Agreement in accordance with the provisions of GCC Subclause 25.2 (Guarantee Test) hereof.

(dd) "Operational Acceptance" means the acceptance by the Employer of the Facilities (or any part of the Facilities where the Contract provides for acceptance of the Facilities in parts), which certifies the Contractor's fulfillment of the Contract in respect of Functional Guarantees of the Facilities (or the relevant part thereof) in accordance with the provisions of GCC Clause 28 (Functional Guarantees) hereof and shall include deemed acceptance in accordance with GCC Clause 25 (Commissioning and Operational Acceptance) hereof.

(ee) "Defect Liability Period" means the period of validity of the warranties given by the Contractor, commencing at Completion of the Facilities or a part thereof, during which the Contractor is responsible for defects with respect to the Facilities (or the relevant part thereof) as provided in GCC Clause 27 (Defect Liability) hereof.

\section{Contract Documents}

3. Interpretation
2.1 Subject to Article 1.2 (Order of Precedence) of the Contract Agreement, all documents forming part of the Contract (and all parts thereof) are intended to be correlative, complementary, and mutually explanatory. The Contract shall be read as a whole.

3.1 In the Contract, except where the context requires otherwise,

(a) words indicating one gender include all genders;

(b) words indicating the singular also include the plural and words indicating the plural also include the singular; 
(c) provisions including the word "agree," "agreed," or "agreement" require the agreement to be record in writing;

(d) the word "tender" is synonymous with "bid," "tenderer" with "Bidder," and "tender documents" with "Bidding Documents;" and

(e) "written" or "in writing" means handwritten, typewritten, printed or electronically made, and resulting in a permanent record.

The marginal words and other headings shall not be taken into consideration in the interpretation of these Conditions.

\subsection{Incoterms}

Unless inconsistent with any provision of the Contract, the meaning of any trade term and the rights and obligations of parties thereunder shall be as prescribed by Incoterms.

"Incoterms" means international rules for interpreting trade terms published by the International Chamber of Commerce (latest edition), 38 Cours Albert 1 $1^{\text {er }}, 75008$ Paris, France.

\subsection{Entire Agreement}

Subject to GCC Subclause 16.4 hereof, the Contract constitutes the entire agreement between the Employer and Contractor with respect to the subject matter of Contract and supersedes all communications, negotiations, and agreements (whether written or oral) of parties with respect thereto made prior to the date of Contract.

\subsection{Amendment}

No amendment or other variation of the Contract shall be effective unless it is in writing, is dated, expressly refers to the Contract, and is signed by a duly authorized representative of each party hereto.

\subsection{Independent Contractor}

The Contractor shall be an independent contractor performing the Contract. The Contract does not create any agency, partnership, joint venture, or other joint relationship between the parties hereto. Subject to the provisions of the Contract, the Contractor shall be solely responsible for the manner in which the Contract is performed. All employees, representatives, or Subcontractors engaged by the Contractor in connection with the performance of the Contract shall be under the complete control of the Contractor and shall not be deemed to be employees of the Employer, and nothing contained in the Contract or in any subcontract awarded by the Contractor shall be construed to create any contractual relationship between any such employees, representatives, or Subcontractors and the Employer. 


\subsection{Non-Waiver}

3.6.1 Subject to GCC Subclause 3.6.2 below, no relaxation, forbearance, delay, or indulgence by either party in enforcing any of the terms and conditions of the Contract or the granting of time by either party to the other shall prejudice, affect, or restrict the rights of that party under the Contract, nor shall any waiver by either party of any breach of Contract operate as waiver of any subsequent or continuing breach of Contract.

3.6.2 Any waiver of a party's rights, powers, or remedies under the Contract must be in writing, must be dated, and signed by an authorized representative of the party granting such waiver, and must specify the right and the extent to which it is being waived.

\subsection{Severability}

If any provision or condition of the Contract is prohibited or rendered invalid or unenforceable, such prohibition, invalidity, or unenforceability shall not affect the validity or enforceability of any other provisions and conditions of the Contract.

\subsection{Country of Origin}

"Origin" means the place where the plant and component parts thereof are mined, grown, produced, or manufactured, and from which the services are provided. Plant components are produced when, through manufacturing, processing, or substantial or major assembling of components, a commercially recognized product results that differs substantially in its basic characteristics or in purpose or utility from its components.

4. Communications

\section{Law and Language}

4.1 Wherever these Conditions provide for the giving or issuing of approvals, certificates, consents, determinations, notices, requests, and discharges, these communications shall be

(a) in writing and delivered against receipt; and

(b) delivered, sent, or transmitted to the address for the recipient's communications as stated in the Contract Agreement.

When a certificate is issued to a Party, the certifier shall send a copy to the other Party. When a notice is issued to a Party, by the other Party or the Project Manager, a copy shall be sent to the Project Manager or the other Party, as the case may be.

5.1 The Contract shall be governed by and interpreted in accordance with laws of the country specified in the SCC.

5.2 The ruling language of the Contract shall be that stated in the SCC.

5.3 The language for communications shall be the ruling language unless otherwise stated in the SCC. 


\section{Fraud and Corruption}

6.1 ADB requires Borrowers (including beneficiaries of ADB-financed activity) and their personnel, as well as firms and individuals participating in an ADB-financed activity, including but not limited to, Bidders, Suppliers, and Contractors, agents, subcontractors, subconsultants, service providers, subsuppliers, manufacturers (including their respective officers, directors, employees and personnel) under ADB-financed contracts to observe the highest standard of ethics during the procurement and execution of such contracts in accordance with ADB's Anticorruption Policy (1998, as amended from time to time). In pursuance of this policy, ADB

(a) defines, for the purposes of this provision, the terms set forth below as follows:

(i) "corrupt practice" means the offering, giving, receiving, or soliciting, directly or indirectly, anything of value to influence improperly the actions of another party;

(ii) "fraudulent practice" means any act or omission, including a misrepresentation, that knowingly or recklessly misleads, or attempts to mislead, a party to obtain a financial or other benefit or to avoid an obligation;

(iii) "coercive practice" means impairing or harming, or threatening to impair or harm, directly or indirectly, any party or the property of the party to influence improperly the actions of a party;

(iv) "collusive practice" means an arrangement between two or more parties designed to achieve an improper purpose, including influencing improperly the actions of another party;

(v) "abuse" means theft, waste, or improper use of assets related to ADB-related activity, either committed intentionally or through reckless disregard;

(vi) "conflict of interest" means any situation in which a party has interests that could improperly influence that party's performance of official duties or responsibilities, contractual obligations, or compliance with applicable laws and regulations;

(vii) "integrity violation" is any act, as defined under ADB's Integrity Principles and Guidelines (2015, as amended from time to time), which violates ADB's Anticorruption Policy, including (i) to (vi) above and the following: obstructive practice, violations of $A D B$ sanctions, retaliation against whistleblowers or witnesses, and other violations of ADB's Anticorruption Policy, including failure to adhere to the highest ethical standard. 
(b) will reject a proposal for award if it determines that the Bidder recommended for award or any of its officers, directors, employees, personnel, subconsultants, subcontractors, service providers, suppliers or manufacturers has, directly or through an agent, engaged in corrupt, fraudulent, collusive, coercive, or obstructive practices or other integrity violations in competing for the Contract;

(c) will cancel the portion of the financing allocated to a contract if it determines at any time that representatives of the Borrower or of a beneficiary of the ADB-financing engaged in corrupt, fraudulent, collusive, coercive, or obstructive practices or other integrity violations during the procurement or the execution of that contract, without the Borrower having taken timely and appropriate action satisfactory to $A D B$ to remedy the situation, including by failing to inform $A D B$ in a timely manner at the time they knew of the integrity violations;

(d) will impose remedial actions on a firm or an individual, at any time, in accordance with ADB's Anticorruption Policy and Integrity Principles and Guidelines, including declaring ineligible, either indefinitely or for a stated period of time, to participate ${ }^{1}$ in ADB-financed, -administered, or -supported activities or to benefit from an ADB-financed, -administered, or -supported contract, financially or otherwise, if it at any time determines that the firm or individual has, directly or through an agent, engaged in corrupt, fraudulent, collusive, coercive, or obstructive practices or other integrity violations; and

(e) will have the right to require that a provision be included in bidding documents and in contracts financed, administered, or supported by $A D B$, requiring Bidders, suppliers and contractors, consultants, manufacturers, service providers and other third parties engaged or involved in ADB-related activities, and their respective officers, directors, employees and personnel, to permit ADB or its representative to inspect the site and their assets, accounts and records and other documents relating to the bid submission and contract performance and to have them audited by auditors appointed by ADB.

6.2 All Bidders, consultants, contractors, suppliers, manufacturers, service providers, and other third parties engaged or involved in ADB-related activities and their respective officers, directors, employees and personnel, are obliged to cooperate fully in any investigation when requested by ADB to do so. As determined on a case by case basis by ADB, such cooperation includes, but is not limited to, the following:

(a) being available to be interviewed and replying fully and truthfully to all questions asked;

(b) providing ADB with any items requested that are within the party's control including, but not limited to, documents and other physical objects;

Whether as a Contractor, Subcontractor, Consultant, Manufacturer or Supplier, or Service Provider; or in any other capacity (different names are used depending on the particular Bidding Document). 
(c) upon written request by $A D B$, authorizing other related entities to release directly to $A D B$ such information that is specifically and materially related, directly or indirectly, to the said entities or issues which are the subject of the investigation;

(d) cooperating with all reasonable requests to search or physically inspect their person and/or work areas, including files, electronic databases, and personal property used on ADB activities, or that utilizes ADB's Information and Communications Technology (ICT) resources or systems (including mobile phones, personal electronic devices, and electronic storage devices such as external disk drives);

(e) cooperating in any testing requested by $A D B$, including but not limited to, fingerprint identification, handwriting analysis, and physical examination and analysis; and

preserving and protecting confidentiality of all information discussed with, and as required by, $\mathrm{ADB}$.

6.3 All Bidders, consultants, contractors and suppliers shall require their officers, directors, employees, personnel, agents to ensure that, in its contract with its sub-consultants, subcontractors, and other third parties engaged or involved in ADB-related activities, such sub-consultants, subcontractors, and other third parties similarly are obliged to cooperate fully in any investigation when requested by ADB to do so.

The Contractor undertakes that no fees, gratuities, rebates, gifts, commissions or other payments, other than those shown in the bid, have been given or received in connection with the procurement process or in the contract execution. ${ }^{2}$

\section{B. Subject Matter of Contract}

7. Scope of Facilities
7.1 Unless otherwise expressly limited in the Employer's Requirements, the Contractor's obligations cover the provision of all Plant and the performance of all Installation Services required for the design, the manufacture (including procurement, quality assurance, construction, installation, associated civil works, precommissioning, and delivery) of the Plant and the installation, completion, and commissioning of the Facilities in accordance with the plans, procedures, specifications, drawings, codes, and any other documents as specified in the section Employer's Requirements. Such specifications include, but are not limited to, the provision of supervision and engineering services; the supply of labor, materials, equipment, spare parts (as specified in GCC Subclause 7.3 below) and accessories; Contractor's Equipment; construction utilities and supplies; temporary materials, structures, and facilities; transportation (including, without limitation, unloading and hauling to, from and at the Site); and storage, except for those supplies, works, and services that will be provided or performed by the Employer, as set forth in the Appendix (Scope of Works and Supply by the Employer) to the Contract Agreement.

2 The undertaking also applies during the period of performance of the contract. 
7.2 The Contractor shall, unless specifically excluded in the Contract, perform all such work and/or supply all such items and materials not specifically mentioned in the Contract but that can be reasonably inferred from the Contract as being required for attaining Completion of the Facilities as if such work and/or items and materials were expressly mentioned in the Contract.

7.3 In addition to the supply of Mandatory Spare Parts included in the Contract, the Contractor agrees to supply spare parts required for the operation and maintenance of the Facilities for the period specified in the SCC and the provisions, if any, specified in the SCC. However, the identity, specifications, and quantities of such spare parts and the terms and conditions relating to the supply thereof are to be agreed between the Employer and the Contractor, and the price of such spare parts shall be that given in Price Schedule No. 6, which shall be added to the Contract Price. The price of such spare parts shall include the purchase price therefore and other costs and expenses (including the Contractor's fees) relating to the supply of spare parts.

\section{Time for Commencement and Completion}

8.1 The Contractor shall commence work on the Facilities within the period specified in the SCC and without prejudice to GCC Subclause 26.2 hereof, the Contractor shall thereafter proceed with the Facilities in accordance with the time schedule specified in the Appendix 4 (Time Schedule) to the Contract Agreement.

8.2 The Contractor shall attain Completion of the Facilities or of a part where a separate time for Completion of such part is specified in the Contract, within the time stated in the SCC or within such extended time to which the Contractor shall be entitled under GCC Clause 40 hereof.

\section{Contractor's Responsibilities}

9.1 The Contractor shall design, manufacture, including associated purchases and/or subcontracting, install, and complete the Facilities in accordance with the Contract. When completed, the Facilities should be fit for the purposes for which they are intended as defined in the Contract.

9.2 The Contractor confirms that it has entered into this Contract on the basis of a proper examination of the data relating to the Facilities, including any data as to boring tests provided by the Employer, and on the basis of information that the Contractor could have obtained from a visual inspection of the Site if access thereto was available and of other data readily available to it relating to the Facilities as of the date 28 days prior to bid submission. The Contractor acknowledges that any failure to acquaint itself with all such data and information shall not relieve its responsibility for properly estimating the difficulty or cost of successfully performing the Facilities.

9.3 The Contractor shall acquire and pay for all permits, approvals, and/or licenses from all local, state, or national government authorities or public service undertakings in the country where the Site is located, which such authorities or undertakings require the Contractor to obtain in its name and which are necessary for the performance of the Contract, including, without limitation, visas for the Contractor's and Subcontractor's personnel and entry permits for all imported Contractor's Equipment. The Contractor shall acquire all other permits, approvals, and/or licenses that are not the responsibility of the Employer under GCC Subclause 10.3 hereof and that are necessary for the performance of the Contract. 
9.4 The Contractor shall comply with all laws in force in the country where the Facilities are to be implemented. The laws will include all local, state, national, or other laws that affect the performance of the Contract and bind upon the Contractor. The Contractor shall indemnify and hold harmless the Employer from and against any and all liabilities, damages, claims, fines, penalties, and expenses of whatever nature arising or resulting from the violation of such laws by the Contractor or its personnel, including the Subcontractors and their personnel, but without prejudice to GCC Subclause 10.1 hereof.

9.5 Any plant and services that will be incorporated in or be required for the Facilities and other supplies shall have their origin as specified under GCC Clause 1 (Country of Origin). Any subcontractors retained by the Contractor shall be from a country as specified in GCC Clause 1 (Country of Origin).

9.6 The Contractor shall permit ADB or its representative to inspect the Contractor's site, assets, accounts and records, and other documents relating to the bid submission and contract performance of the Contractor and to have them audited by auditors appointed by $A D B$, if so required by ADB.

9.7 If the Contractor is a joint venture or consortium of two or more persons, all such persons shall be jointly and severally bound to the Employer for the fulfillment of the provisions of the Contract and shall designate one of such persons to act as a leader with authority to bind the joint venture or consortium. The composition or the constitution of the joint venture or consortium shall not be altered without the prior consent of the Employer.

9.8 Protection of the Environment

(a) The Contractor shall take all reasonable steps to protect the environment (both on and off the Site) and to limit damage and nuisance to people and property resulting from pollution, noise, and other results of his operations.

(b) The Contractor shall ensure that emissions, surface discharges, and effluent from the Contractor's activities shall not exceed the values stated in the Specification or prescribed by applicable Laws.

\section{Employer's Responsibilities}

10.1 All information and/or data to be supplied by the Employer as described in the Appendix (Scope of Works and Supply by the Employer) to the Contract Agreement shall be deemed to be accurate, except when the Employer expressly states otherwise.

10.2 The Employer shall be responsible for acquiring and providing legal and physical possession of the Site and access thereto, and for providing possession of and access to all other areas reasonably required for the proper execution of the Contract, including all requisite rights of way, as specified in the Appendix (Scope of Works and Supply by the Employer) to the Contract Agreement. The Employer shall give full possession of and accord all rights of access thereto on or before the date(s) specified in that Appendix. 
10.3 The Employer shall acquire and pay for all permits, approvals, and/or licenses from all local, state, or national government authorities, or public service undertakings in the country where the Site is located which (a) such authorities or undertakings require the Employer to obtain in the Employer's name, (b) are necessary for the execution of the Contract, including those required for the performance by both the Contractor and the Employer of their respective obligations under the Contract, and (c) are specified in the Appendix (Scope of Works and Supply by the Employer) to the Contract Agreement.

10.4 If requested by the Contractor, the Employer shall use its best endeavors to assist the Contractor in obtaining in a timely and expeditious manner all permits, approvals, and/or licenses necessary for the execution of the Contract from all local, state, or national government authorities, or public service undertakings that such authorities or undertakings require the Contractor or Subcontractors or the personnel of the Contractor or Subcontractors, as the case may be, to obtain.

10.5 Unless otherwise specified in the Contract or agreed upon by the Employer and the Contractor, the Employer shall provide sufficient, properly qualified operating and maintenance personnel; shall supply and make available all raw materials, utilities, lubricants, chemicals, catalysts, other materials, and facilities; and shall perform all work and services of whatsoever nature, including those required by the Contractor to properly carry out Pre-commissioning, Commissioning, and Guarantee Tests, all in accordance with the provisions of the Appendix (Scope of Works and Supply by the Employer) to the Contract Agreement at or before the time specified in the program furnished by the Contractor under GCC Subclause 18.2 hereof and in the manner thereupon specified or as otherwise agreed upon by the Employer and the Contractor.

10.6 The Employer shall be responsible for the continued operation of the Facilities after Completion, in accordance with GCC Subclause 24.8, and shall be responsible for facilitating the Guarantee Test(s) for the Facilities, in accordance with GCC Subclause 25.2.

10.7 All costs and expenses involved in the performance of the obligations under this GCC Clause 10 shall be the responsibility of the Employer, except those incurred by the Contractor with respect to the performance of Guarantee Tests, in accordance with GCC Subclause 25.2.

10.8 In the event that the Employer shall be in breach of any of his obligations imposed by the Contract, then the additional cost reasonably incurred by the Contractor in consequence thereof shall be added to the Contract Price.

\section{Payment}

11. Contract Price
11.1 The Contract Price shall be as specified in Article 2 (Contract Price and Terms of Payment) of the Contract Agreement.

11.2 Unless an adjustment clause is provided for in the SCC, the Contract Price shall be a firm lump sum not subject to any alteration, except in the event of a Change in the Facilities or as otherwise provided in the Contract. 


\section{Terms of Payment}

13. Securities
11.3 Subject to GCC Subclauses 9.2, 10.1, and 35 hereof, the Contractor shall be deemed to have satisfied itself as to the correctness and sufficiency of the Contract Price, which shall, except as otherwise provided for in the Contract, cover all its obligations under the Contract.

12.1 The Contract Price shall be paid as specified in Article 2 (Contract Price and Terms of Payment) of the Contract Agreement and in the Appendix (Terms and Procedures of Payment) to the Contract Agreement, which also outlines the procedures to be followed in making application for and processing payments.

12.2 No payment made by the Employer herein shall be deemed to constitute acceptance by the Employer of the Facilities or any part(s) thereof.

12.3 In the event that the Employer fails to make any payment by its respective due date or within the period set forth in the Contract, the Employer shall pay to the Contractor interest on the amount of such delayed payment at the rate(s) shown in the Appendix (Terms and Procedures of Payment) to the Contract Agreement for the period of delay until payment has been made in full, whether before or after judgment or arbitrage award.

12.4 The currency or currencies in which payments are made to the Contractor under this Contract shall be specified in the Appendix (Terms and Procedures of Payment) to the Contract Agreement, subject to the general principle that payments will be made in the currency or currencies in which the Contract Price has been stated in the Contractor's bid.

\subsection{Issuance of Securities}

The Contractor shall provide the securities specified below in favor of the Employer at the times, and in the amount, manner, and form specified below.

\subsection{Advance Payment Security}

13.2.1 The Contractor shall, within 28 days of the notification of contract award, provide a security in an amount equal to the advance payment calculated in accordance with the Appendix (Terms and Procedures of Payment) to the Contract Agreement, and in the same currency or currencies.

13.2.2 The security shall be in the form provided in the Bidding Documents or in another form acceptable to the Employer. The amount of the security shall be reduced in proportion to the value of the Facilities executed by and paid to the Contractor from time to time, and shall automatically become null and void when the full amount of the advance payment has been recovered by the Employer. The security shall be returned to the Contractor immediately after its expiration.

\subsection{Performance Security}

13.3.1 The Contractor shall, within 28 days of the notification of contract award, provide a security for the due performance of the Contract in the amount specified in the SCC 
13.3.2 The security shall be denominated in the currency or currencies of the Contract, or in a freely convertible currency acceptable to the Employer, and shall be in one of the forms of bank guarantees provided in the Bidding Documents, as stipulated by the Employer in the SCC, or in another form acceptable to the Employer.

13.3.3 Unless otherwise specified in the SCC, the security shall be reduced by half on the date of the Operational Acceptance. The Security shall become null and void, or shall be reduced pro rata to the Contract Price of a part of the Facilities for which a separate Time for Completion is provided, 540 days after Completion of the Facilities or 365 days after Operational Acceptance of the Facilities, whichever occurs first; provided, however, that if the Defects Liability Period has been extended on any part of the Facilities pursuant to GCC Subclause 27.8 hereof, the Contractor shall issue an additional security in an amount proportionate to the Contract Price of that part. The security shall be returned to the Contractor immediately after its expiration, provided, however, that if the Contractor, pursuant to GCC Subclause 27.10, is liable for an extended defect liability obligation, the performance security shall be extended for the period and up to the amount specified in the SCC.

\section{Taxes and Duties}

14.1 Except as otherwise specifically provided in the Contract, the Contractor shall bear and pay all taxes, duties, levies, and charges assessed on the Contractor, its Subcontractors, or their employees by all municipal, state, or national government authorities in connection with the Facilities in and outside of the country where the Site is located.

14.2 Notwithstanding GCC Subclause 14.1 above, the Employer shall bear and promptly pay all customs and import duties as well as other local taxes like, e.g., a value-added tax (VAT), imposed by the law of the country where the Site is located on the Plant specified in Price Schedule No. 1 and that are to be incorporated into the Facilities.

14.3 If any tax exemptions, reductions, allowances, or privileges may be available to the Contractor in the country where the Site is located, the Employer shall use its best endeavors to enable the Contractor to benefit from any such tax savings to the maximum allowable extent.

14.4 For the purpose of the Contract, it is agreed that the Contract Price specified in Article 2 (Contract Price and Terms of Payment) of the Contract Agreement is based on the taxes, duties, levies, and charges prevailing at the date 28 days prior to the date of bid submission in the country where the Site is located (hereinafter called "Tax" in this GCC Subclause 14.4). If any rates of Tax are increased or decreased, a new Tax is introduced, an existing Tax is abolished, or any change in interpretation or application of any Tax occurs in the course of the performance of Contract, which was or will be assessed on the Contractor, Subcontractors, or their employees in connection with performance of the Contract, an equitable adjustment of the Contract Price shall be made to fully take into account any such change by addition to the Contract Price or deduction therefrom, as the case may be, in accordance with GCC Clause 36 hereof. 


\section{Intellectual Property}

\section{License/Use of Technical Information}

\section{Confidential Information}

15.1 For the operation and maintenance of the Plant, the Contractor hereby grants a non-exclusive and nontransferable license (without the right to sublicense) to the Employer under the patents, utility models, or other industrial property rights owned by the Contractor or by a third party from whom the Contractor has received the right to grant licenses thereunder, and shall also grant to the Employer a nonexclusive and nontransferable right (without the right to sublicense) to use the know-how and other technical information disclosed to the Employer under the Contract. Nothing contained herein shall be construed as transferring ownership of any patent, utility model, trademark, design, copyright, know-how, or other intellectual property right from the Contractor or any third party to the Employer.

15.2 The copyright in all drawings, documents, and other materials containing data and information furnished to the Employer by the Contractor herein shall remain vested in the Contractor or, if they are furnished to the Employer directly or through the Contractor by any third party, including suppliers of materials, the copyright in such materials shall remain vested in such third party.

16.1 The Employer and the Contractor shall keep confidential and shall not, without the written consent of the other party hereto, divulge to any third party any documents, data, or other information furnished directly or indirectly by the other party hereto in connection with the Contract, whether such information has been furnished prior to, during, or following termination of the Contract. Notwithstanding the above, the Contractor may furnish to its Subcontractor(s) such documents, data, and other information it receives from the Employer to the extent required for the Subcontractor(s) to perform its work under the Contract, in which event the Contractor shall obtain from such Subcontractor(s) an undertaking of confidentiality similar to that imposed on the Contractor under this GCC Clause 16.

16.2 The Employer shall not use such documents, data, and other information received from the Contractor for any purpose other than the operation and maintenance of the Facilities. Similarly, the Contractor shall not use such documents, data, and other information received from the Employer for any purpose other than the design, procurement of Plant, construction, or such other work and services as are required for the performance of the Contract.

16.3 The obligation of a party under GCC Subclauses 16.1 and 16.2 above, however, shall not apply to that information, which

(a) now or hereafter enters the public domain through no fault of that party;

(b) can be proven to have been possessed by that party at the time of disclosure and which was not previously obtained, directly or indirectly, from the other party hereto; and

(c) otherwise lawfully becomes available to that party from a third party that has no obligation of confidentiality. 
16.4 The above provisions of this GCC Clause 16 shall not in any way modify any undertaking of confidentiality given by either of the parties hereto prior to the date of the Contract in respect of the Facilities or any part thereof.

16.5 The provisions of this GCC Clause 16 shall survive termination, for whatever reason, of the Contract.

\section{E. Execution of the Facilities}

\section{Representatives}

\subsection{Project Manager}

If the Project Manager is not named in the Contract, then within 14 days of the Effective Date, the Employer shall appoint and notify the Contractor in writing of the name of the Project Manager. The Employer may from time to time appoint some other person as the Project Manager in place of the person previously so appointed, and shall give notice of the name of such other person to the Contractor without delay. No such appointment shall be made at such a time or in such a manner as to impede the progress of work on the Facilities. Such appointment shall only take effect upon receipt of such notice by the Contractor. The Project Manager shall represent and act for the Employer at all times during the performance of the Contract. All notices, instructions, orders, certificates, approvals, and all other communications under the Contract shall be given by the Project Manager, except as herein otherwise provided.

All notices, instructions, information, and other communications given by the Contractor to the Employer under the Contract shall be given to the Project Manager, except as herein otherwise provided.

\subsection{Contractor's Representative and Construction Manager}

17.2.1 If the Contractor's Representative is not named in the Contract, then within 14 days of the Effective Date, the Contractor shall appoint the Contractor's Representative and shall request the Employer in writing to approve the person so appointed. If the Employer makes no objection to the appointment within 14 days, the Contractor's Representative shall be deemed to have been approved. If the Employer objects to the appointment within 14 days, giving the reason therefor, then the Contractor shall appoint a replacement within 14 days of such objection, and the foregoing provisions of this GCC Subclause 17.2.1 shall apply thereto.

17.2.2 The Contractor's Representative shall represent and act for the Contractor at all times during the performance of the Contract and shall give to the Project Manager all the Contractor's notices, instructions, information, and all other communications under the Contract. 
All notices, instructions, information, and all other communications given by the Employer or the Project Manager to the Contractor under the Contract shall be given to the Contractor's Representative or, in its absence, its deputy, except as herein otherwise provided.

The Contractor shall not revoke the appointment of the Contractor's Representative without the Employer's prior written consent, which shall not be unreasonably withheld. If the Employer consents thereto, the Contractor shall appoint some other person as the Contractor's Representative, pursuant to the procedure set out in GCC Subclause 17.2.1.

17.2.3 The Contractor's Representative may, subject to the approval of the Employer, which shall not be unreasonably withheld, at any time delegate to any person any of the powers, functions, and authorities vested in him or her. Any such delegation may be revoked at any time. Any such delegation or revocation shall be subject to a prior notice signed by the Contractor's Representative, and shall specify the powers, functions, and authorities thereby delegated or revoked. No such delegation or revocation shall take effect unless and until a copy thereof has been delivered to the Employer and the Project Manager.

Any act or exercise by any person of powers, functions, and authorities so delegated to him or her in accordance with this GCC Subclause 17.2.3 shall be deemed to be an act or exercise by the Contractor's Representative.

17.2.4 From the commencement of installation of the Facilities at the Site until Completion, the Contractor's Representative shall appoint a suitable person as the Construction Manager. The Construction Manager shall supervise all work done at the Site by the Contractor and shall be present at the Site throughout normal working hours except when on leave, sick, or absent for reasons connected with the proper performance of the Contract. Whenever the Construction Manager is absent from the Site, the Contractor's Representative or the Construction Manager shall appoint a suitable person to act as the Construction Manager's deputy.

17.2.5 The Employer may by notice to the Contractor object to any representative or person employed by the Contractor in the execution of the Contract who, in the reasonable opinion of the Employer, may behave inappropriately, may be incompetent or negligent, or may commit a serious breach of the Site regulations provided under GCC Subclause 22.4. The Employer shall provide evidence of the same, whereupon the Contractor shall remove such person from the Facilities.

17.2.6 If any representative or person employed by the Contractor is removed in accordance with GCC Subclause 17.2.5, the Contractor shall, where required, promptly appoint a replacement. 
18. Work Program

\subsection{Contractor's Organization}

The Contractor shall supply to the Employer and the Project Manager a chart showing the proposed organization to be established by the Contractor for carrying out work on the Facilities within 21 days of the Effective Date. The chart shall include the identities of the key personnel, and the curricula vitae of such key personnel to be employed shall be supplied together with the chart. The Contractor shall promptly inform the Employer and the Project Manager in writing of any revision or alteration of such an organization chart.

\subsection{Program of Performance}

Within 28 days after the Effective Date, the Contractor shall submit to the Project Manager a detailed program of performance of the Contract, made in a form acceptable to the Project Manager and showing the sequence in which it proposes to design, manufacture, transport, assemble, install, and precommission the Facilities, as well as the date by which the Contractor reasonably requires that the Employer shall have fulfilled its obligations under the Contract so as to enable the Contractor to execute the Contract in accordance with the program and to achieve Completion, Commissioning, and Acceptance of the Facilities in accordance with the Contract. The program so submitted by the Contractor shall accord with the Time Schedule included in the Appendix (Time Schedule) to the Contract Agreement and any other dates and periods specified in the Contract. The Contractor shall update and revise the program as and when appropriate or when required by the Project Manager, but without modification in the Times for Completion given in the SCC and any extension granted in accordance with GCC Clause 40, and shall submit all such revisions to the Project Manager.

\subsection{Progress Report}

The Contractor shall monitor progress of all the activities specified in the program referred to in GCC Subclause 18.2 above, and supply a progress report to the Project Manager every month.

The progress report shall be in a form acceptable to the Project Manager and shall indicate (a) percentage completion achieved compared with the planned percentage completion for each activity; and (b) where any activity is behind the program, giving comments and likely consequences and stating the corrective action being taken. 


\subsection{Progress of Performance}

If at any time the Contractor's actual progress falls behind the program referred to in GCC Subclause 18.2, or it becomes apparent that it will so fall behind, the Contractor shall, at the request of the Employer or the Project Manager, prepare and submit to the Project Manager a revised program, taking into account the prevailing circumstances, and shall notify the Project Manager of the steps being taken to expedite progress so as to attain Completion of the Facilities within the Time for Completion under GCC Subclause 8.2, any extension thereof entitled under GCC Subclause 40.1 , or any extended period as may otherwise be agreed upon between the Employer and the Contractor.

\subsection{Procedures}

The Contract shall be executed in accordance with the Contract Documents, including the procedures given in the Forms and Procedures of the Employer's Requirements.

The Contractor may execute the Contract in accordance with its own standard project execution plans and procedures to the extent that they do not conflict with the provisions contained in the Contract.

19. Subcontracting

19.1 The Appendix 5 (List of Major Items of Plant and Services and List of Approved Subcontractors) to the Contract Agreement specifies major items of plant and services and a list of approved Subcontractors against each item, including manufacturers. Insofar as no Subcontractors are listed against any such item, the Contractor shall prepare a list of Subcontractors for such item for inclusion in such list. The Contractor may from time to time propose any addition to or deletion from any such list. The Contractor shall submit any such list or any modification thereto to the Employer for its approval in sufficient time so as not to impede the progress of work on the Facilities. Such approval by the Employer for any of the Subcontractors shall not relieve the Contractor from any of its obligations, duties, or responsibilities under the Contract.

19.2 The Contractor shall select and employ its Subcontractors for such major items from those listed in the lists referred to in GCC Subclause 19.1.

19.3 For items or parts of the Facilities not specified in the Appendix (List of Major Items of Plant and Services and List of Approved Subcontractors for Major Items) to the Contract Agreement, the Contractor may employ such Subcontractors as it may select, at its discretion.

19.4 Each subcontract shall include provisions which would entitle the Employer to require the subcontract to be assigned to the Employer under GCC 19.5 (if and when applicable), or in event of termination by the Employer under GCC 42.2.

19.5 If a Subcontractor's obligations extend beyond the expiry date of the relevant Defects Liability Period, and the Project Manager, prior to that date, instructs the Contractor to assign the benefits of such obligations to the Employer, then the Contractor shall do so. 


\section{Design and Engineering}

\subsection{Specifications and Drawings}

20.1.1 The Contractor shall execute the basic and detailed design and the engineering work in compliance with the provisions of the Contract, or where not so specified, in accordance with good engineering practice.

The Contractor shall be responsible for any discrepancies, errors, or omissions in the specifications, drawings, and other technical documents that it has prepared, whether such specifications, drawings, and other documents have been approved by the Project Manager or not, provided that such discrepancies, errors, or omissions are not because of inaccurate information furnished in writing to the Contractor by or on behalf of the Employer.

20.1.2 The Contractor shall be entitled to disclaim responsibility for any design, data, drawing, specification, or other document, or any modification thereof provided or designated by or on behalf of the Employer, by giving a notice of such disclaimer to the Project Manager.

\subsection{Codes and Standards}

Wherever references are made in the Contract to codes and standards in accordance with which the Contract shall be executed, the edition or the revised version of such codes and standards current at the date 28 days prior to date of bid submission shall apply unless otherwise specified. During Contract execution, any changes in such codes and standards shall be applied subject to approval by the Employer and shall be treated in accordance with GCC Clause 39.

\subsection{Approval/Review of Technical Documents by Project Manager}

20.3.1 The Contractor shall prepare or cause its Subcontractors to prepare and furnish to the Project Manager the documents listed in the Appendix (List of Documents for Approval or Review) to the Contract Agreement for its approval or review as specified and in accordance with the requirements of GCC Subclause 18.2 (Program of Performance).

Any part of the Facilities covered by or related to the documents to be approved by the Project Manager shall be executed only after the Project Manager's approval thereof.

GCC Subclauses 20.3.2 through 20.3.7 shall apply to those documents requiring the Project Manager's approval, but not to those furnished to the Project Manager for its review only. 
20.3.2 Within 14 days after receipt by the Project Manager of any document requiring the Project Manager's approval in accordance with GCC Subclause 20.3.1, the Project Manager shall either return one copy thereof to the Contractor with its approval endorsed thereon or shall notify the Contractor in writing of its disapproval thereof and the reasons therefor and the modifications that the Project Manager proposes.

If the Project Manager fails to take such action within the said 14 days, then the said document shall be deemed to have been approved by the Project Manager.

20.3.3 The Project Manager shall not disapprove any document, except on the grounds that the document does not comply with the Contract or that it is contrary to good engineering practice. If the Project Manager disapproves a document, he shall specify the reasons for his decision.

20.3.4 If the Project Manager disapproves the document, the Contractor shall modify the document and resubmit it for the Project Manager's approval in accordance with GCC Subclause 20.3.2. If the Project Manager approves the document subject to modification(s), the Contractor shall make the required modification(s), whereupon the document shall be deemed to have been approved.

20.3.5 If any dispute or difference occurs between the Employer and the Contractor in connection with or arising out of the disapproval by the Project Manager of any document and/or any modification(s) thereto that cannot be settled between the parties within a reasonable period, then such dispute or difference may be referred to an Dispute Board for determination in accordance with GCC Subclause 45.3 hereof. If such dispute or difference is referred to a Dispute Board, the Project Manager shall give instructions as to whether and, if so, how, performance of the Contract is to proceed. The Contractor shall proceed with the Contract in accordance with the Project Manager's instructions, provided that if the Dispute Board upholds the Contractor's view on the dispute and if the Employer has not given notice under Subclause 45.3 hereof, then the Contractor shall be reimbursed by the Employer for any additional costs incurred by reason of such instructions and shall be relieved of such responsibility or liability in connection with the dispute and the execution of the instructions as the Dispute Board shall decide, and the Time for Completion shall be extended accordingly. 
20.3.6 The Project Manager's approval, with or without modification of the document furnished by the Contractor, shall not relieve the Contractor of any responsibility or liability imposed upon it by any provisions of the Contract except to the extent that any subsequent failure results from modifications required by the Project Manager.

20.3.7 The Contractor shall not depart from any approved document unless the Contractor has first submitted to the Project Manager an amended document and obtained the Project Manager's approval thereof, pursuant to the provisions of this GCC Subclause 20.3.

If the Project Manager requests any change in any already approved document and/or in any document based thereon, the provisions of GCC Clause 39 shall apply to such request.

\section{Procurement}

\subsection{Materials}

Subject to GCC Subclause 14.2, the Contractor shall procure and transport all materials in an expeditious and orderly manner to the Site.

\subsection{Employer-Supplied Materials}

If the Appendix (Scope of Works and Supply by the Employer) to the Contract Agreement provides that the Employer shall furnish any specific items to the Contractor, the following provisions shall apply:

21.2.1 The Employer shall, at its own risk and expense, transport each item to the place on or near the Site as agreed upon by the parties and make such item available to the Contractor at the time specified in the program furnished by the Contractor, pursuant to GCC Subclause 18.2, unless otherwise mutually agreed.

21.2.2 Upon receipt of such item, the Contractor shall inspect the same visually and notify the Project Manager of any detected shortage, defect, or default. The Employer shall immediately remedy any shortage, defect, or default, or the Contractor shall, if practicable and possible, at the request of the Employer, remedy such shortage, defect, or default at the Employer's cost and expense. After inspection, such item shall fall under the care, custody, and control of the Contractor. The provision of this GCC Subclause 21.2.2 shall apply to any item supplied to remedy any such shortage or default or to substitute for any defective item, or shall apply to defective items that have been repaired.

21.2.3 The foregoing responsibilities of the Contractor and its obligations of care, custody, and control shall not relieve the Employer of liability for any undetected shortage, defect, or default, nor place the Contractor under any liability for any such shortage, defect, or default whether under GCC Clause 27 or under any other provision of Contract. 


\subsection{Transportation}

21.3.1 The Contractor shall at its own risk and expense transport all the materials and the Contractor's Equipment to the Site by the mode of transport that the Contractor judges most suitable under all the circumstances.

21.3.2 Unless otherwise provided in the Contract, the Contractor shall be entitled to select any safe mode of transport operated by any person to carry the materials and the Contractor's Equipment.

21.3.3 Upon dispatch of each shipment of materials and the Contractor's Equipment, the Contractor shall notify the Employer by telex, cable, facsimile, or electronic means, of the description of the materials and of the Contractor's Equipment, the point and means of dispatch, and the estimated time and point of arrival in the country where the Site is located, if applicable, and at the Site. The Contractor shall furnish the Employer with relevant shipping documents to be agreed upon between the parties.

21.3.4 The Contractor shall be responsible for obtaining, if necessary, approvals from the authorities for transportation of the materials and the Contractor's Equipment to the Site. The Employer shall use its best endeavors in a timely and expeditious manner to assist the Contractor in obtaining such approvals, if requested by the Contractor. The Contractor shall indemnify and hold harmless the Employer from and against any claim for damage to roads, bridges, or any other traffic facilities that may be caused by the transport of the materials and the Contractor's Equipment to the Site.

\subsection{Customs Clearance}

The Contractor shall, at its own expense, handle all imported materials and Contractor's Equipment at the point(s) of import and shall handle any formalities for customs clearance, subject to the Employer's obligations under GCC Subclause 14.2, provided that if applicable laws or regulations require any application or act to be made by or in the name of the Employer, the Employer shall take all necessary steps to comply with such laws or regulations. In the event of delays in customs clearance that are not the fault of the Contractor, the Contractor shall be entitled to an extension in the Time for Completion, pursuant to GCC Clause 40.

\section{Installation}

\subsection{Setting Out/Supervision}

\subsubsection{Benchmark}

(a) The Contractor shall be responsible for the true and proper setting-out of the Facilities in relation to benchmarks, reference marks, and lines provided to it in writing by or on behalf of the Employer. 
(b) If, at any time during the progress of installation of the Facilities, any error shall appear in the position, level, or alignment of the Facilities, the Contractor shall forthwith notify the Project Manager of such error and, at its own expense, immediately rectify such error to the reasonable satisfaction of the Project Manager. If such error is based on incorrect data provided in writing by or on behalf of the Employer, the expense of rectifying the same shall be borne by the Employer.

\subsubsection{Contractor's Supervision}

The Contractor shall give or provide all necessary superintendence during the installation of the Facilities, and the Construction Manager or its deputy shall be constantly on the Site to provide full-time superintendence of the installation. The Contractor shall provide and employ only technical personnel who are skilled and experienced in their respective callings and supervisory staff who are competent to adequately supervise the work at hand.

\subsection{Labor}

\subsubsection{Engagement of Staff and Labor}

(a) Except as otherwise stated in the Specification, the Contractor shall make arrangements for the engagement of all staff and labor, local or otherwise, and for their payment, housing, feeding, and transport.

(b) The Contractor shall provide and employ on the Site in the installation of the Facilities such skilled, semi-skilled, and unskilled labor as is necessary for the proper and timely execution of the Contract. The Contractor is encouraged to use local labor that has the necessary skills.

(c) The Contractor shall be responsible for obtaining all necessary permit(s) and/or visa(s) from the appropriate authorities for the entry of all labor and personnel to be employed on the Site into the country where the Site is located. The Employer will, if requested by the Contractor, use his best endeavors in a timely and expeditious manner to assist the Contractor in obtaining any local, state, national, or government permission required for bringing in the Contractor's personnel.

(d) The Contractor shall at its own expense provide the means of repatriation to all of its and its Subcontractor's personnel employed on the Contract at the Site to the place where they were recruited or to their domicile. It shall also provide suitable temporary maintenance of all such persons from the cessation of their employment on the Contract to the date programmed for their departure. In the event that the Contractor defaults in providing such means of transportation and temporary maintenance, the Employer may provide the same to such personnel and recover the cost of doing so from the Contractor. 


\subsubsection{Persons in the Service of Employer}

The Contractor shall not recruit, or attempt to recruit, staff and labor from amongst the Employer's Personnel.

\subsubsection{Labor Laws}

(a) The Contractor shall comply with all the relevant labor Laws applicable to the Contractor's Personnel, including Laws relating to their employment, health, safety, welfare, immigration, and emigration, and shall allow them all their legal rights.

(b) The Contractor shall at all times during the progress of the Contract use its best endeavors to prevent any unlawful, riotous, or disorderly conduct or behavior by or amongst its employees and the labor of its Subcontractors.

(c) The Contractor shall, in all dealings with its labor and the labor of its Subcontractors currently employed on or connected with the Contract, pay due regard to all recognized festivals, official holidays, religious, or other customs and all local laws and regulations pertaining to the employment of labor.

\subsubsection{Rates of Wages and Conditions of Labor}

(a) The Contractor shall pay rates of wages, and observe conditions of labor, which are not lower than those established for the trade or industry where the work is carried out. If no established rates or conditions are applicable, the Contractor shall pay rates of wages and observe conditions which are not lower than the general level of wages and conditions observed locally by employers whose trade or industry is similar to that of the Contractor.

(b) The Contractor shall inform the Contractor's Personnel about their liability to pay personal income taxes in the Country in respect of such of their salaries, wages, and allowances as are chargeable under the Laws for the time being in force, and the Contractor shall perform such duties in regard to such deductions thereof as may be imposed on him by such Laws.

\subsubsection{Working Hours}

(a) No work shall be carried out on the Site on locally recognized days of rest, or outside the normal working hours stated in the SCC, unless

(i) otherwise stated in the Contract;

(ii) the Project Manager gives consent; or

(iii) the work is unavoidable, or necessary for the protection of life or property or for the safety of the Works, in which case the Contractor shall immediately advise the Project Manager. 
(b) If and when the Contractor considers it necessary to carry out work at night or on public holidays so as to meet the Time for Completion and requests the Project Manager's consent thereto, the Project Manager shall not unreasonably withhold such consent.

(c) This Subclause shall not apply to any work which is customarily carried out by rotary or double shifts.

\subsubsection{Facilities for Staff and Labor}

(a) Except as otherwise stated in the Specification, the Contractor shall provide and maintain all necessary accommodation and welfare facilities for the Contractor's Personnel. The Contractor shall also provide facilities for the Employer's Personnel as stated in the Specification.

(b) The Contractor shall not permit any of the Contractor's Personnel to maintain any temporary or permanent living quarters within the structures forming part of the Permanent Works.

\subsubsection{Health and Safety}

(a) The Contractor shall at all times take all reasonable precautions to maintain the health and safety of the Contractor's Personnel. In collaboration with local health authorities, the Contractor shall ensure that medical staff, first aid facilities, sick bay, and ambulance service are available at all times at the Site and at any accommodation for Contractor's and Employer's Personnel, and that suitable arrangements are made for all necessary welfare and hygiene requirements and for the prevention of epidemics.

(b) The Contractor shall appoint an accident prevention officer at the Site, responsible for maintaining safety and protection against accidents. This person shall be qualified for this responsibility, and shall have the authority to issue instructions and take protective measures to prevent accidents. Throughout the performance of the Contract, the Contractor shall provide whatever is required by this person to exercise this responsibility and authority.

(c) The Contractor shall send to the Project Manager, details of any accident as soon as practicable after its occurrence. The Contractor shall maintain records and make reports concerning health, safety, and welfare of persons, and damage to property, as the Project Manager may reasonably require. 


\subsubsection{Funeral Arrangements}

In the event of the death of any of the Contractor's personnel or accompanying members of their families, the Contractor shall be responsible for making the appropriate arrangements for their return or burial, unless otherwise specified in the SCC.

\subsubsection{Records of Contractor's Personnel}

The Contractor shall keep accurate records of the Contractor's personnel, including the number of each class of Contractor's Personnel on the Site and the names, ages, gender, hours worked, and wages paid to all workers. These records shall be summarized on a monthly basis in a form approved by the Project Manager and shall be available for inspection by the Project Manager until the Contractor has completed all work.

\subsubsection{Supply of Foodstuff}

The Contractor shall arrange for the provision of a sufficient supply of suitable food as may be stated in the Specification at reasonable prices for the Contractor's Personnel for the purposes of or in connection with the Contract.

\subsubsection{Supply of Water}

The Contractor shall, having regard to local conditions, provide on the Site an adequate supply of drinking and other water for the use of the Contractor's Personnel.

\subsubsection{Measures against Insect and Pest Nuisance}

The Contractor shall at all times take the necessary precautions to protect the Contractor's Personnel employed on the Site from insect and pest nuisance, and to reduce their danger to health. The Contractor shall comply with all the regulations of the local health authorities, including use of appropriate insecticide.

\subsubsection{Alcoholic Liquor or Drugs}

The Contractor shall not, otherwise than in accordance with the Laws of the Country, import, sell, give barter, or otherwise dispose of any alcoholic liquor or drugs, or permit or allow importation, sale, gift barter, or disposal by Contractor's Personnel.

\subsubsection{Arms and Ammunition}

The Contractor shall not give, barter, or otherwise dispose of, to any person, any arms or ammunition of any kind, or allow Contractor's Personnel to do so. 


\subsubsection{Prohibition of All Forms of Forced or Compulsory Labor}

The contractor shall not employ "forced or compulsory labor" in any form. "Forced or compulsory labor" consists of all work or service, not voluntarily performed, that is extracted from an individual under threat of force or penalty.

\subsubsection{Prohibition of Harmful Child Labor}

The Contractor shall not employ any child to perform any work that is economically exploitative, or is likely to be hazardous to, or to interfere with, the child's education, or to be harmful to the child's health or physical, mental, spiritual, moral, or social development.

\subsection{Contractor's Equipment}

22.3.1 All Contractor's Equipment brought by the Contractor onto the Site shall be deemed to be intended to be used exclusively for the execution of the Contract. The Contractor shall not remove the same from the Site without the Project Manager's consent that such Contractor's Equipment is no longer required for the execution of the Contract.

22.3.2 Unless otherwise specified in the Contract, upon completion of the Facilities, the Contractor shall remove from the Site all Equipment brought by the Contractor onto the Site and any surplus materials remaining thereon.

22.3.3 The Employer will, if requested, use its best endeavors to assist the Contractor in obtaining any local, state, or national government permission required by the Contractor for the export of the Contractor's Equipment imported by the Contractor for use in the execution of the Contract that is no longer required for the execution of the Contract.

\subsection{Site Regulations and Safety}

The Employer and the Contractor shall establish Site regulations setting out the rules to be observed in the execution of the Contract at the Site and shall comply therewith. The Contractor shall prepare and submit to the Employer, with a copy to the Project Manager, proposed Site regulations for the Employer's approval, which approval shall not be unreasonably withheld.

Such Site regulations shall include, but shall not be limited to, rules in respect of security, safety of the Facilities, gate control, sanitation, medical care, and fire prevention.

\subsection{Opportunities for Other Contractors}

22.5.1 The Contractor shall, upon written request from the Employer or the Project Manager, give all reasonable opportunities for carrying out the work to any other contractors employed by the Employer on or near the Site. 
22.5.2 If the Contractor, upon written request from the Employer or the Project Manager, makes available to other contractors any roads or ways the maintenance for which the Contractor is responsible, permits the use by such other contractors of the Contractor's Equipment, or provides any other service of whatsoever nature for such other contractors, the Employer shall fully compensate the Contractor for any loss or damage caused or occasioned by such other contractors in respect of any such use or service, and shall pay to the Contractor reasonable remuneration for the use of such equipment or the provision of such services.

22.5.3 The Contractor shall also so arrange to perform its work as to minimize, to the extent possible, interference with the work of other contractors. The Project Manager shall determine the resolution of any difference or conflict that may arise between the Contractor and other contractors and the workers of the Employer in regard to their work.

22.5.4 The Contractor shall notify the Project Manager promptly of any defects in the other Contractors' work that come to its notice, and that could affect the Contractor's work. The Project Manager shall determine the corrective measures, if any, required to rectify the situation after inspection of the Facilities. Decisions made by the Project Manager shall be binding on the Contractor.

\subsection{Emergency Work}

If, by reason of an emergency arising in connection with and during the execution of the Contract, any protective or remedial work is necessary as a matter of urgency to prevent damage to the Facilities, the Contractor shall immediately carry out such work.

If the Contractor is unable or unwilling to do such work immediately, the Employer may do or cause such work to be done as the Employer may determine is necessary in order to prevent damage to the Facilities. In such event, the Employer shall, as soon as practicable after the occurrence of any such emergency, notify the Contractor in writing of such emergency, the work done and the reasons therefore. If the work done or caused to be done by the Employer is work that the Contractor was liable to do at its own expense under the Contract, the reasonable costs incurred by the Employer in connection therewith shall be paid by the Contractor to the Employer. Otherwise, the cost of such remedial work shall be borne by the Employer.

\subsection{Site Clearance}

\subsubsection{Site Clearance in Course of Performance}

In the course of carrying out the Contract, the Contractor shall keep the Site reasonably free from all unnecessary obstruction, store, or remove any surplus materials, clear away any wreckage, rubbish, or temporary works from the Site, and remove any Contractor's Equipment no longer required for execution of the Contract. 


\subsubsection{Clearance of Site after Completion}

After Completion of all parts of the Facilities, the Contractor shall clear away and remove all wreckage, rubbish, and debris of any kind from the Site, and shall leave the Site and Facilities in a clean and safe condition.

\subsection{Watching and Lighting}

The Contractor shall provide and maintain at its own expense all lighting, fencing, and watching when and where necessary for the proper execution and the protection of the Facilities, or for the safety of the owners and occupiers of adjacent property and for the safety of the public.

\section{Test and Inspection}

23.1 The Contractor shall at its own expense carry out at the place of manufacture and/or on the Site all such tests and/or inspections of the Plant and any part of the Facilities as are specified in the Contract.

23.2 The Employer and the Project Manager or their designated representatives shall be entitled to attend the aforesaid test and/or inspection, provided that the Employer shall bear all costs and expenses incurred in connection with such attendance including, but not limited to, all traveling and board and lodging expenses.

23.3 Whenever the Contractor is ready to carry out any such test and/or inspection, the Contractor shall give a reasonable advance notice of such test and/or inspection and of the place and time thereof to the Project Manager. The Contractor shall obtain from any relevant third party or manufacturer any necessary permission or consent to enable the Employer and the Project Manager or their designated representatives to attend the test and/or inspection.

23.4 The Contractor shall provide the Project Manager with a certified report of the results of any such test and/or inspection.

If the Employer or Project Manager or their designated representatives fails to attend the test and/or inspection, or if it is agreed between the parties that such persons shall not do so, then the Contractor may proceed with the test and/or inspection in the absence of such persons, and may provide the Project Manager with a certified report of the results thereof.

23.5 The Project Manager may require the Contractor to carry out any test and/or inspection not required by the Contract, provided that the Contractor's reasonable costs and expenses incurred in the carrying out of such test and/or inspection shall be added to the Contract Price. Further, if such test and/or inspection impedes the progress of work on the Facilities and/or the Contractor's performance of its other obligations under the Contract, due allowance will be made in respect of the Time for Completion and the other obligations so affected.

23.6 If any Plant or any part of the Facilities fails to pass any test and/or inspection, the Contractor shall either rectify or replace such Plant or part of the Facilities and shall repeat the test and/or inspection upon giving a notice under GCC Subclause 23.3. 
23.7 If any dispute or difference of opinion shall arise between the parties in connection with or arising out of the test and/or inspection of the Plant or part of the Facilities that cannot be settled between the parties within a reasonable period of time, it may be referred to an Dispute Board for determination in accordance with GCC Subclause 45.3.

23.8 The Contractor shall afford the Employer and the Project Manager, at the Employer's expense, access at any reasonable time to any place where the Plant are being manufactured or the Facilities are being installed, in order to inspect the progress and the manner of manufacture or installation, provided that the Project Manager shall give the Contractor a reasonable prior notice.

23.9 The Contractor agrees that neither the execution of a test and/or inspection of Plant or any part of the Facilities, nor the attendance by the Employer or the Project Manager, nor the issue of any test certificate pursuant to GCC Subclause 23.4, shall release the Contractor from any other responsibilities under the Contract.

23.10 No part of the Facilities or foundations shall be covered up on the Site without the Contractor carrying out any test and/or inspection required under the Contract. The Contractor shall give a reasonable notice to the Project Manager whenever any such parts of the Facilities or foundations are ready or about to be ready for test and/or inspection; such test and/or inspection and notice thereof shall be subject to the requirements of the Contract.

23.11 The Contractor shall uncover any part of the Facilities or foundations, or shall make openings in or through the same as the Project Manager may from time to time require at the Site, and shall reinstate and make good such part or parts.

If any parts of the Facilities or foundations have been covered up at the Site after compliance with the requirement of GCC Subclause 23.10 and are found to be executed in accordance with the Contract, the expenses of uncovering, making openings in or through, reinstating, and making good the same shall be borne by the Employer, and the Time for Completion shall be reasonably adjusted to the extent that the Contractor has thereby been delayed or impeded in the performance of any of its obligations under the Contract.

\section{Completion of the Facilities}

24.1 As soon as the Facilities or any part thereof has, in the opinion of the Contractor, been completed operationally and structurally and put in a tight and clean condition as specified in the Employer's Requirements, excluding minor items not materially affecting the operation or safety of the Facilities, the Contractor shall so notify the Employer in writing. 
24.2 Within 7 days after receipt of the notice from the Contractor under GCC Subclause 24.1, the Employer shall supply the operating and maintenance personnel specified in the Appendix (Scope of Works and Supply by the Employer) to the Contract Agreement for Pre-commissioning of the Facilities or any part thereof.

Pursuant to the Appendix (Scope of Works and Supply by the Employer) to the Contract Agreement, the Employer shall also provide, within the said 7-day period, the raw materials, utilities, lubricants, chemicals, catalysts, facilities, services, and other matters required for Pre-commissioning of the Facilities or any part thereof.

24.3 As soon as reasonably practicable after the operating and maintenance personnel have been supplied by the Employer and the raw materials, utilities, lubricants, chemicals, catalysts, facilities, services, and other matters have been provided by the Employer in accordance with GCC Subclause 24.2, the Contractor shall commence Pre-commissioning of the Facilities or the relevant part thereof in preparation for Commissioning, subject to GCC Subclause 25.5.

24.4 As soon as all works in respect of Pre-commissioning are completed and, in the opinion of the Contractor, the Facilities or any part thereof is ready for Commissioning, the Contractor shall so notify the Project Manager in writing.

24.5 The Project Manager shall, within 14 days after receipt of the Contractor's notice under GCC Subclause 24.4, either issue a Completion Certificate in the form specified in the Employer's Requirements (Forms and Procedures), stating that the Facilities or that part thereof have reached Completion as of the date of the Contractor's notice under GCC Subclause 24.4, or notify the Contractor in writing of any defects and/or deficiencies.

If the Project Manager notifies the Contractor of any defects and/or deficiencies, the Contractor shall then correct such defects and/or deficiencies, and shall repeat the procedure described in GCC Subclause 24.4.

If the Project Manager is satisfied that the Facilities or that part thereof have reached Completion, the Project Manager shall, within 7 days after receipt of the Contractor's repeated notice, issue a Completion Certificate stating that the Facilities or that part thereof have reached Completion as of the date of the Contractor's repeated notice.

If the Project Manager is not so satisfied, then it shall notify the Contractor in writing of any defects and/or deficiencies within 7 days after receipt of the Contractor's repeated notice, and the above procedure shall be repeated.

24.6 If the Project Manager fails to issue the Completion Certificate and fails to inform the Contractor of any defects and/or deficiencies within 14 days after receipt of the Contractor's notice under GCC Subclause 24.4 or within 7 days after receipt of the Contractor's repeated notice under GCC Subclause 24.5, or if the Employer makes use of the Facilities or part thereof, then the Facilities or that part thereof shall be deemed to have reached Completion as of the date of the Contractor's notice or repeated notice, or as of the Employer's use of the Facilities, as the case may be. 
24.7 As soon as possible after Completion, the Contractor shall complete all outstanding minor items so that the Facilities are fully in accordance with the requirements of the Contract, failing which the Employer will undertake such completion and deduct the costs thereof from any monies owing to the Contractor.

24.8 Upon Completion, the Employer shall be responsible for the care and custody of the Facilities or the relevant part thereof, together with the risk of loss or damage thereto, and shall thereafter take over the Facilities or the relevant part thereof.

\section{Commissioning and Operational Acceptance}

\subsection{Commissioning}

25.1.1 Commissioning of the Facilities or any part thereof shall be commenced by the Contractor immediately after issue of the Completion Certificate by the Project Manager, pursuant to GCC Subclause 24.5, or immediately after the date of the deemed Completion, under GCC Subclause 24.6.

25.1.2 The Employer shall supply the operating and maintenance personnel and all raw materials, utilities, lubricants, chemicals, catalysts, facilities, services, and other matters required for Commissioning.

25.1.3 In accordance with the requirements of the Contract, the Contractor's and Project Manager's advisory personnel shall attend the Commissioning, including the Guarantee Test, and shall advise and assist the Employer.

\subsection{Guarantee Test}

25.2.1 Subject to GCC Subclause 25.5, the Guarantee Test and repeats thereof shall be conducted by the Contractor during Commissioning of the Facilities or the relevant part thereof to ascertain whether the Facilities or the relevant part can attain the Functional Guarantees specified in the Appendix (Functional Guarantees) to the Contract Agreement. The Employer shall promptly provide the Contractor with such information as the Contractor may reasonably require in relation to the conduct and results of the Guarantee Test and any repeats thereof.

25.2.2 If for reasons not attributable to the Contractor, the Guarantee Test of the Facilities or the relevant part thereof cannot be successfully completed within the period from the date of Completion specified in the SCC or any other period agreed upon by the Employer and the Contractor, the Contractor shall be deemed to have fulfilled its obligations with respect to the Functional Guarantees, and GCC Subclauses 28.2 and 28.3 shall not apply. 


\subsection{Operational Acceptance}

25.3.1 Subject to GCC Subclause 25.4 below, Operational Acceptance shall occur in respect of the Facilities or any part thereof when

(a) the Guarantee Test has been successfully completed and the Functional Guarantees are met; or

(b) the Guarantee Test has not been successfully completed or has not been carried out for reasons not attributable to the Contractor within the period from the date of Completion specified in the SCC, or any other agreed upon period as specified in GCC Subclause 25.2.2 above; or

(c) the Contractor has paid the liquidated damages specified in GCC Subclause 28.3 hereof; and

(d) any minor items mentioned in GCC Subclause 24.7 hereof relevant to the Facilities or that part thereof have been completed.

25.3.2 At any time after any of the events set out in GCC Subclause 25.3.1 have occurred, the Contractor may give a notice to the Project Manager requesting the issue of an Operational Acceptance Certificate in the form provided in the Employer's Requirements (Forms and Procedures) in respect of the Facilities or the part thereof specified in such notice as of the date of such notice.

25.3.3 The Project Manager shall, after consultation with the Employer, and within 7 days after receipt of the Contractor's notice, issue an Operational Acceptance Certificate.

25.3.4 If within 7 days after receipt of the Contractor's notice, the Project Manager fails to issue the Operational Acceptance Certificate or fails to inform the Contractor in writing of the justifiable reasons why the Project Manager has not issued the Operational Acceptance Certificate, the Facilities or the relevant part thereof shall be deemed to have been accepted as of the date of the Contractor's said notice.

\subsection{Partial Acceptance}

25.4.1 If the Contract specifies that Completion and Commissioning shall be carried out in respect of parts of the Facilities, the provisions relating to Completion and Commissioning including the Guarantee Test shall apply to each such part of the Facilities individually, and the Operational Acceptance Certificate shall be issued accordingly for each such part of the Facilities.

25.4.2 If a part of the Facilities comprises facilities such as buildings, for which no Commissioning or Guarantee Test is required, then the Project Manager shall issue the Operational Acceptance Certificate for such facility when it attains Completion, provided that the Contractor shall thereafter complete any outstanding minor items that are listed in the Operational Acceptance Certificate. 


\subsection{Delayed PreCommissioning and/or Guarantee Test}

25.5.1 In the event that the Contractor is unable to proceed with the Precommissioning of the Facilities pursuant to Subclause 24.3, or with the Guarantee Test pursuant to Subclause 25.2, for reasons attributable to the Employer either on account of nonavailability of other facilities under the responsibilities of other contractor(s), or for reasons beyond the Employer's control, the provisions leading to "deemed" completion of activities such as Completion, pursuant to GCC Subclause 24.6, and Operational Acceptance, pursuant to GCC Subclause 25.3.4, and Contractor's obligations regarding Defect Liability Period, pursuant to GCC Subclause 27.2, Functional Guarantee, pursuant to GCC Clause 28, and Care of Facilities, pursuant to GCC Clause 32, and GCC Clause 41.1, Suspension, shall not apply. In this case, the following provisions shall apply.

25.5.2 When the Contractor is notified by the Project Manager that he will be unable to proceed with the activities and obligations pursuant to above Subclause 25.5.1, the Contractor shall be entitled to the following:

(a) the Time of Completion shall be extended for the period of suspension without imposition of liquidated damages pursuant to GCC Subclause 26.2;

(b) payments due to the Contractor in accordance with the provision specified in the Appendix (Terms and Procedures of Payment) to the Contract Agreement, which would not have been payable in normal circumstances due to noncompletion of the subject activities, shall be released to the Contractor against submission of a security in the form of a bank guarantee of equivalent amount acceptable to the Employer, and which shall become null and void when the Contractor will have complied with its obligations regarding those payments, subject to the provision of Subclause 25.5.3 below;

(c) the expenses towards the above security and extension of other securities under the contract, of which validity needs to be extended, shall be reimbursed to the Contractor by the Employer;

(d) the additional charges towards the care of the Facilities pursuant to GCC Subclause 32.1 shall be reimbursed to the Contractor by the Employer for the period between the notification mentioned above and the notification mentioned in Subclause 25.5.4 below. The provision of GCC Subclause 33.2 shall apply to the Facilities during the same period. 
25.5.3 In the event that the period of suspension under above Subclause 25.5.1 actually exceeds 180 days, the Employer and Contractor shall mutually agree to any additional compensation payable to the Contractor.

25.5.4 When the Contractor is notified by the Project Manager that the plant is ready for Pre-commissioning, the Contractor shall proceed without delay in performing all the specified activities and obligations under the contract.

\section{F. Guarantees and Liabilities}

\section{Completion Time Guarantee}

26.1 The Contractor guarantees that it shall attain Completion of the Facilities (or a part for which a separate time for completion is specified) within the Time for Completion specified in the SCC pursuant to GCC Subclause 8.2, or within such extended time to which the Contractor shall be entitled under GCC Clause 40 hereof.

26.2 If the Contractor fails to attain Completion of the Facilities or any part thereof within the Time for Completion or any extension thereof under GCC Clause 40, the Contractor shall pay to the Employer liquidated damages in the amount specified in the SCC as a percentage rate of the Contract Price or the relevant part thereof. The aggregate amount of such liquidated damages shall in no event exceed the amount specified as "Maximum" in the SCC as a percentage rate of the Contract Price. Once the "Maximum" is reached, the Employer may consider termination of the Contract, pursuant to GCC Subclause 42.2.2.

Such payment shall completely satisfy the Contractor's obligation to attain Completion of the Facilities or the relevant part thereof within the Time for Completion or any extension thereof under GCC Clause 40. The Contractor shall have no further liability whatsoever to the Employer in respect thereof.

However, the payment of liquidated damages shall not in any way relieve the Contractor from any of its obligations to complete the Facilities or from any other obligations and liabilities of the Contractor under the Contract.

Save for liquidated damages payable under this GCC Subclause 26.2, the failure by the Contractor to attain any milestone or other act, matter, or thing by any date specified in the Appendix (Time Schedule) to the Contract Agreement and/or other program of work prepared pursuant to GCC Subclause 18.2 shall not render the Contractor liable for any loss or damage thereby suffered by the Employer.

26.3 If the Contractor attains Completion of the Facilities or any part thereof before the Time for Completion or any extension thereof under GCC Clause 40, the Employer shall pay to the Contractor a bonus in the amount specified in the SCC. The aggregate amount of such bonus shall in no event exceed the amount specified as "Maximum" in the SCC. 
27. Defect Liability
27.1 The Contractor warrants that the Facilities or any part thereof shall be free from defects in the design, engineering, materials, and workmanship of the Plant supplied and of the work executed.

27.2 The Defect Liability Period shall be 540 days from the date of Completion of the Facilities (or any part thereof) or 1 year from the date of Operational Acceptance of the Facilities (or any part thereof), whichever first occurs, unless specified otherwise in the SCC pursuant to GCC Subclause 27.10.

If during the Defect Liability Period any defect should be found in the design, engineering, materials, and workmanship of the Plant supplied or of the work executed by the Contractor, the Contractor shall promptly, in consultation and agreement with the Employer regarding appropriate remedying of the defects, and at its cost, repair, replace, or otherwise make good as the Contractor shall determine at its discretion, such defect as well as any damage to the Facilities caused by such defect. The Contractor shall not be responsible for the repair, replacement, or making good of any defect, or of any damage to the Facilities arising out of or resulting from any of the following causes:

(a) improper operation or maintenance of the Facilities by the Employer,

(b) operation of the Facilities outside specifications provided in the Contract, or

(c) normal wear and tear.

27.3 The Contractor's obligations under this GCC Clause 27 shall not apply to

(a) any materials that are supplied by the Employer under GCC Subclause 21.2, are normally consumed in operation, or have a normal life shorter than the Defect Liability Period stated herein;

(b) any designs, specifications, or other data designed, supplied, or specified by or on behalf of the Employer or any matters for which the Contractor has disclaimed responsibility herein; or

(c) any other materials supplied or any other work executed by or on behalf of the Employer, except for the work executed by the Employer under GCC Subclause 27.7.

27.4 The Employer shall give the Contractor a notice stating the nature of any such defect together with all available evidence thereof, promptly following the discovery thereof. The Employer shall afford all reasonable opportunity for the Contractor to inspect any such defect.

27.5 The Employer shall afford the Contractor all necessary access to the Facilities and the Site to enable the Contractor to perform its obligations under this GCC Clause 27.

The Contractor may, with the consent of the Employer, remove from the Site any Plant or any part of the Facilities that are defective if the nature of the defect, and/or any damage to the Facilities caused by the defect, is such that repairs cannot be expeditiously carried out at the Site. 
27.6 If the repair, replacement, or making good is of such a character that it may affect the efficiency of the Facilities or any part thereof, the Employer may give to the Contractor a notice requiring that tests of the defective part of the Facilities shall be made by the Contractor immediately upon completion of such remedial work, whereupon the Contractor shall carry out such tests.

If such part fails the tests, the Contractor shall carry out further repair, replacement, or making good, as the case may be, until that part of the Facilities passes such tests. The tests shall be agreed upon by the Employer and the Contractor.

27.7 If the Contractor fails to commence the work necessary to remedy such defect or any damage to the Facilities caused by such defect within a reasonable time (which shall in no event be considered to be less than 15 days), the Employer may, following notice to the Contractor, proceed to do such work, and the reasonable costs incurred by the Employer in connection therewith shall be paid to the Employer by the Contractor or may be deducted by the Employer from any monies due the Contractor or claimed under the Performance Security.

27.8 If the Facilities or any part thereof cannot be used by reason of such defect and/or making good of such defect, the Defect Liability Period of the Facilities or such part, as the case may be, shall be extended by a period equal to the period during which the Facilities or such part cannot be used by the Employer because of any of the aforesaid reasons.

27.9 Except as provided in GCC Clauses 27 and 33, the Contractor shall be under no liability whatsoever and howsoever arising, and whether under the Contract or at law, in respect of defects in the Facilities or any part thereof, the Plant, design, or engineering, or work executed that appear after Completion of the Facilities or any part thereof, except where such defects are the result of the gross negligence, fraud, criminal, or willful action of the Contractor.

27.10 In addition, any such component of the Facilities and during the period of time as may be specified in the SCC shall be subject to an extended defect liability period. Such obligation of the Contractor shall be in addition to the defect liability period specified under GCC Subclause 27.2.

\section{Functional Guarantees}

28.1 The Contractor guarantees that during the Guarantee Test, the Facilities and all parts thereof shall attain the Functional Guarantees specified in the Appendix (Functional Guarantees) to the Contract Agreement, subject to, and upon the conditions therein specified.

28.2 If, for reasons attributable to the Contractor, the minimum level of the Functional Guarantees specified in the Appendix (Functional Guarantees) to the Contract Agreement are not met either in whole or in part, the Contractor shall at its cost and expense make such changes, modifications, and/or additions to the Plant or any part thereof as may be necessary to meet at least the minimum level of such Guarantees. The Contractor shall notify the Employer upon completion of the necessary changes, modifications, and/or additions, and shall request the Employer to repeat the Guarantee Test until the minimum level of the Guarantees has been met. If the Contractor eventually fails to meet the minimum level of Functional Guarantees, the Employer may consider termination of the Contract, pursuant to GCC Subclause 42.2.2. 
28.3 If, for reasons attributable to the Contractor, the Functional Guarantees specified in the Appendix (Functional Guarantees) to the Contract Agreement are not attained either in whole or in part, but the minimum level of the Functional Guarantees specified in the said Appendix to the Contract Agreement is met, the Contractor shall, at the Contractor's option, either

(a) make such changes, modifications, and/or additions to the Facilities or any part thereof that are necessary to attain the Functional Guarantees at its cost and expense, and shall request the Employer to repeat the Guarantee Test; or

(b) pay liquidated damages to the Employer in respect of the failure to meet the Functional Guarantees in accordance with the provisions in the Appendix (Functional Guarantees) to the Contract Agreement.

28.4 The payment of liquidated damages under GCC Subclause 28.3, up to the limitation of liability specified in the Appendix (Functional Guarantees) to the Contract Agreement, shall completely satisfy the Contractor's guarantees under GCC Subclause 28.3, and the Contractor shall have no further liability whatsoever to the Employer in respect thereof. Upon the payment of such liquidated damages by the Contractor, the Project Manager shall issue the Operational Acceptance Certificate for the Facilities or any part thereof in respect of which the liquidated damages have been so paid.

29. Patent Indemnity
29.1 The Contractor shall, subject to the Employer's compliance with GCC Subclause 29.2, indemnify and hold harmless the Employer and its employees and officers from and against any and all suits, actions, or administrative proceedings, claims, demands, losses, damages, costs, and expenses of whatsoever nature, including attorney's fees and expenses, which the Employer may suffer as a result of any infringement or alleged infringement of any patent, utility model, registered design, trademark, copyright, or other intellectual property right registered or otherwise existing at the date of the Contract by reason of (a) the installation of the Facilities by the Contractor or the use of the Facilities in the country where the Site is located, and (b) the sale of the products produced by the Facilities in any country.

Such indemnity shall not cover any use of the Facilities or any part thereof other than for the purpose indicated by or to be reasonably inferred from the Contract, any infringement resulting from the use of the Facilities or any part thereof, or any products produced thereby in association or combination with any other equipment, plant, or materials not supplied by the Contractor, pursuant to the Contract Agreement. 
29.2 If any proceedings are brought or any claim is made against the Employer arising out of the matters referred to in GCC Subclause 29.1, the Employer shall promptly give the Contractor a notice thereof, and the Contractor may at its own expense and in the Employer's name conduct such proceedings or claim and any negotiations for the settlement of any such proceedings or claim.

If the Contractor fails to notify the Employer within 28 days after receipt of such notice that it intends to conduct any such proceedings or claim, then the Employer shall be free to conduct the same on its own behalf. Unless the Contractor has so failed to notify the Employer within the 28day period, the Employer shall make no admission that may be prejudicial to the defense of any such proceedings or claim.

The Employer shall, at the Contractor's request, afford all available assistance to the Contractor in conducting such proceedings or claim, and shall be reimbursed by the Contractor for all reasonable expenses incurred in so doing.

29.3 The Employer shall indemnify and hold harmless the Contractor and its employees, officers, and Subcontractors from and against any and all suits, actions, or administrative proceedings, claims, demands, losses, damages, costs, and expenses of whatsoever nature, including attorney's fees and expenses, which the Contractor may suffer as a result of any infringement or alleged infringement of any patent, utility model, registered design, trademark, copyright, or other intellectual property right registered or otherwise existing at the date of the Contract arising out of or in connection with any design, data, drawing, specification, or other documents or materials provided or designed by or on behalf of the Employer.

\section{Limitation} of Liability
30.1 Except in cases of criminal negligence or willful misconduct,

(a) the Contractor shall not be liable to the Employer, whether in contract, tort, or otherwise, for any indirect or consequential loss or damage, loss of use, loss of production, or loss of profits or interest costs, provided that this exclusion shall not apply to any obligation of the Contractor to pay liquidated damages to the Employer; and

(b) the aggregate liability of the Contractor to the Employer, whether under the Contract, in tort or otherwise, shall not exceed a multiple of the Contract Price specified in the SCC or, if a multiple is not so specified, the total Contract Price, provided that this limitation shall not apply to the cost of repairing or replacing defective equipment, or to any obligation of the Contractor to indemnify the Employer with respect to patent infringement. 


\section{G. Risk Distribution}

\section{Transfer of Ownership}

32. Care of Facilities
31.1 Ownership of the Plant (including spare parts) to be imported into the country where the Site is located shall be transferred to the Employer upon loading on to the mode of transport to be used to convey the Plant from the country of origin to that country.

31.2 Ownership of the Plant (including spare parts) procured in the country where the Site is located shall be transferred to the Employer when the Plant are brought on to the Site.

31.3 Ownership of the Contractor's Equipment used by the Contractor and its Subcontractors in connection with the Contract shall remain with the Contractor or its Subcontractors.

31.4 Ownership of any Plant in excess of the requirements for the Facilities shall revert to the Contractor upon Completion of the Facilities or at such earlier time when the Employer and the Contractor agree that the Plant in question are no longer required for the Facilities.

31.5 Notwithstanding the transfer of ownership of the Plant, the responsibility for care and custody thereof together with the risk of loss or damage thereto shall remain with the Contractor pursuant to GCC Clause 32 (Care of Facilities) hereof until Completion of the Facilities or the part thereof in which such Plant are incorporated.

32.1 The Contractor shall be responsible for the care and custody of the Facilities or any part thereof until the date of Completion of the Facilities pursuant to GCC Clause 24 or, where the Contract provides for Completion of the Facilities in parts, until the date of Completion of the relevant part, and shall make good at its own cost any loss or damage that may occur to the Facilities or the relevant part thereof from any cause whatsoever during such period. The Contractor shall also be responsible for any loss or damage to the Facilities caused by the Contractor or its Subcontractors in the course of any work carried out, pursuant to GCC Clause 27. Notwithstanding the foregoing, the Contractor shall not be liable for any loss or damage to the Facilities or that part thereof caused by reason of any of the matters specified or referred to in paragraphs (a), (b), and (c) of GCC Subclauses 32.2 and 38.1.

32.2 If any loss or damage occurs to the Facilities or any part thereof or to the Contractor's temporary facilities by reason of

(a) insofar as they relate to the country where the Site is located, nuclear reaction, nuclear radiation, radioactive contamination, pressure wave caused by aircraft or other aerial objects, or any other occurrences that an experienced contractor could not reasonably foresee, or if reasonably foreseeable could not reasonably make provision for or insure against, insofar as such risks are not normally insurable on the insurance market and are mentioned in the general exclusions of the policy of insurance, including War Risks and Political Risks, taken out under GCC Clause 34 hereof; or 
(b) any use or occupation by the Employer or any third party other than a Subcontractor, authorized by the Employer of any part of the Facilities; or

(c) any use of or reliance upon any design, data, or specification provided or designated by or on behalf of the Employer, or any such matter for which the Contractor has disclaimed responsibility herein,

the Employer shall pay to the Contractor all sums payable in respect of the Facilities executed, notwithstanding that the same be lost, destroyed, or damaged, and will pay to the Contractor the replacement value of all temporary facilities and all parts thereof lost, destroyed, or damaged. If the Employer requests the Contractor in writing to make good any loss or damage to the Facilities thereby occasioned, the Contractor shall make good the same at the cost of the Employer in accordance with GCC Clause 39. If the Employer does not request the Contractor in writing to make good any loss or damage to the Facilities thereby occasioned, the Employer shall either request a change in accordance with GCC Clause 39, excluding the performance of that part of the Facilities thereby lost, destroyed, or damaged, or, where the loss or damage affects a substantial part of the Facilities, the Employer shall terminate the Contract pursuant to GCC Subclause 42.1 hereof.

32.3 The Contractor shall be liable for any loss of or damage to any Contractor's Equipment, or any other property of the Contractor used or intended to be used for purposes of the Facilities, except (i) as mentioned in GCC Subclause 32.2 with respect to the Contractor's temporary facilities, and (ii) where such loss or damage arises by reason of any of the matters specified in GCC Subclauses 32.2(b) and (c) and 38.1.

32.4 With respect to any loss or damage caused to the Facilities or any part thereof or to the Contractor's Equipment by reason of any of the matters specified in GCC Subclause 38.1, the provisions of GCC Subclause 38.3 shall apply.

33. Loss of or Damage to Property; Accident or Injury to Workers; Indemnification
33.1 Subject to GCC Subclause 33.3, the Contractor shall indemnify and hold harmless the Employer and its employees and officers from and against any and all suits, actions, or administrative proceedings, claims, demands, losses, damages, costs, and expenses of whatsoever nature, including attorney's fees and expenses, in respect of the death or injury of any person or loss of or damage to any property other than the Facilities whether accepted or not, arising in connection with the supply and installation of the Facilities and by reason of the negligence of the Contractor or its Subcontractors, or their employees, officers, or agents, except any injury, death, or property damage caused by the negligence of the Employer, its contractors, employees, officers, or agents. 
33.2 If any proceedings are brought or any claim is made against the Employer that might subject the Contractor to liability under GCC Subclause 33.1, the Employer shall promptly give the Contractor a notice thereof and the Contractor may at its own expense and in the Employer's name conduct such proceedings or claim and any negotiations for the settlement of any such proceedings or claim.

If the Contractor fails to notify the Employer within 28 days after receipt of such notice that it intends to conduct any such proceedings or claim, then the Employer shall be free to conduct the same on its own behalf. Unless the Contractor has so failed to notify the Employer within the 28day period, the Employer shall make no admission that may be prejudicial to the defense of any such proceedings or claim.

The Employer shall, at the Contractor's request, afford all available assistance to the Contractor in conducting such proceedings or claim, and shall be reimbursed by the Contractor for all reasonable expenses incurred in so doing.

33.3 The Employer shall indemnify and hold harmless the Contractor and its employees, officers, and Subcontractors from any liability for loss of or damage to property of the Employer, other than the Facilities not yet taken over, that is caused by fire, explosion, or any other perils, in excess of the amount recoverable from insurances procured under GCC Clause 34, provided that such fire, explosion, or other perils were not caused by any act or failure of the Contractor.

33.4 The party entitled to the benefit of an indemnity under this GCC Clause 33 shall take all reasonable measures to mitigate any loss or damage which has occurred. If the party fails to take such measures, the other party's liabilities shall be correspondingly reduced.

34. Insurance

34.1 To the extent specified in the Appendix (Insurance Requirements) to the Contract Agreement, the Contractor shall at its expense take out and maintain in effect, or cause to be taken out and maintained in effect, during the performance of the Contract, the insurances set forth below in the sums and with the deductibles and other conditions specified in the said Appendix. The identity of the insurers and the form of the policies shall be subject to the approval of the Employer, who should not unreasonably withhold such approval.

\section{(a) Cargo Insurance During Transport}

Covering loss or damage occurring while in transit from the Contractor's or Subcontractor's works or stores until arrival at the Site, to the Plant (including spare parts therefor) and to the Contractor's Equipment. 


\section{(b) Installation All Risks Insurance}

Covering physical loss or damage to the Facilities at the Site, occurring prior to Completion of the Facilities, with an extended maintenance coverage for the Contractor's liability in respect of any loss or damage occurring during the Defect Liability Period while the Contractor is on the Site for the purpose of performing its obligations during the Defect Liability Period.

\section{(c) Third Party Liability Insurance}

Covering bodily injury or death suffered by third parties including the Employer's personnel, and loss of or damage to property, occurring in connection with the supply and installation of the Facilities.

\section{(d) Automobile Liability Insurance}

Covering use of all vehicles used by the Contractor or its Subcontractors, whether or not owned by them, in connection with the execution of the Contract.

\section{(e) Workers' Compensation}

In accordance with the statutory requirements applicable in any country where the Contract or any part thereof is executed.

\section{(f) Employer's Liability}

In accordance with the statutory requirements applicable in any country where the Contract or any part thereof is executed.

\section{(g) Other Insurances}

Such other insurances as may be specifically agreed upon by the parties hereto as listed in the Appendix (Insurance Requirements) to the Contract Agreement.

34.2 The Employer shall be named as co-insured under all insurance policies taken out by the Contractor pursuant to GCC Subclause 34.1, except for the Third Party Liability, Workers' Compensation, and Employer's Liability Insurances, and the Contractor's Subcontractors shall be named as co-insureds under all insurance policies taken out by the Contractor pursuant to GCC Subclause 34.1 except for the Cargo Insurance During Transport, Workers' Compensation, and Employer's Liability Insurances. All insurer's rights of subrogation against such co-insureds for losses or claims arising out of the performance of the Contract shall be waived under such policies.

34.3 The Contractor shall, in accordance with the provisions of the Appendix (Insurance Requirements) to the Contract Agreement, deliver to the Employer certificates of insurance or copies of the insurance policies as evidence that the required policies are in full force and effect. The certificates shall provide that no less than 21 days' notice shall be given to the Employer by insurers prior to cancellation or material modification of a policy. 
34.4 The Contractor shall ensure that, where applicable, its Subcontractor(s) shall take out and maintain in effect adequate insurance policies for their personnel and vehicles and for work executed by them under the Contract, unless such Subcontractors are covered by the policies taken out by the Contractor.

34.5 The Employer shall at its expense take out and maintain in effect during the performance of the Contract those insurances specified in the Appendix (Insurance Requirements) to the Contract Agreement, in the sums and with the deductibles and other conditions specified in the said Appendix. The Contractor and the Contractor's Subcontractors shall be named as coinsureds under all such policies. All insurers' rights of subrogation against such co-insureds for losses or claims arising out of the performance of the Contract shall be waived under such policies. The Employer shall deliver to the Contractor satisfactory evidence that the required insurances are in full force and effect. The policies shall provide that not less than 21 days' notice shall be given to the Contractor by all insurers prior to any cancellation or material modification of the policies. If so requested by the Contractor, the Employer shall provide copies of the policies taken out by the Employer under this GCC Subclause 34.5.

34.6 If the Contractor fails to take out and/or maintain in effect the insurances referred to in GCC Subclause 34.1, the Employer may take out and maintain in effect any such insurances and may from time to time deduct from any amount due the Contractor under the Contract any premium that the Employer shall have paid to the insurer, or may otherwise recover such amount as a debt due from the Contractor. If the Employer fails to take out and/or maintain in effect the insurances referred to in GCC 34.5, the Contractor may take out and maintain in effect any such insurances and may from time to time deduct from any amount due the Employer under the Contract any premium that the Contractor shall have paid to the insurer, or may otherwise recover such amount as a debt due from the Employer. If the Contractor fails to or is unable to take out and maintain in effect any such insurances, the Contractor shall nevertheless have no liability or responsibility towards the Employer, and the Contractor shall have full recourse against the Employer for any and all liabilities of the Employer herein.

34.7 Unless otherwise provided in the Contract, the Contractor shall prepare and conduct all and any claims made under the policies effected by it pursuant to this GCC Clause 34, and all monies payable by any insurers shall be paid to the Contractor. The Employer shall give to the Contractor all such reasonable assistance as may be required by the Contractor. With respect to insurance claims in which the Employer's interest is involved, the Contractor shall not give any release or make any compromise with the insurer without the prior written consent of the Employer. With respect to insurance claims in which the Contractor's interest is involved, the Employer shall not give any release or make any compromise with the insurer without the prior written consent of the Contractor. 
35. Unforeseen Conditions
35.1 If, during the execution of the Contract, the Contractor shall encounter on the Site any physical conditions other than climatic conditions, or artificial obstructions that could not have been reasonably foreseen prior to the date of the Contract Agreement by an experienced contractor on the basis of reasonable examination of the data relating to the Facilities, including any data as to boring tests, provided by the Employer, and on the basis of information that it could have obtained from a visual inspection of the Site if access thereto was available, or other data readily available to it relating to the Facilities, and if the Contractor determines that it will in consequence of such conditions or obstructions incur additional cost and expense or require additional time to perform its obligations under the Contract that would not have been required if such physical conditions or artificial obstructions had not been encountered, the Contractor shall promptly, and before performing additional work or using additional Plant or Contractor's Equipment, notify the Project Manager in writing of

(a) the physical conditions or artificial obstructions on the Site that could not have been reasonably foreseen;

(b) the additional work and/or Plant and/or Contractor's Equipment required, including the steps which the Contractor will or proposes to take to overcome such conditions or obstructions;

(c) the extent of the anticipated delay; and

(d) the additional cost and expense that the Contractor is likely to incur.

On receiving any notice from the Contractor under this GCC Subclause 35.1, the Project Manager shall promptly consult with the Employer and Contractor and decide upon the actions to be taken to overcome the physical conditions or artificial obstructions encountered. Following such consultations, the Project Manager shall instruct the Contractor, with a copy to the Employer, of the actions to be taken.

35.2 Any reasonable additional cost and expense incurred by the Contractor in following the instructions from the Project Manager to overcome such physical conditions or artificial obstructions referred to in GCC Subclause 35.1 shall be paid by the Employer to the Contractor as an addition to the Contract Price.

35.3 If the Contractor is delayed or impeded in the performance of the Contract because of any such physical conditions or artificial obstructions referred to in GCC Subclause 35.1, the Time for Completion shall be extended in accordance with GCC Clause 40. 
36. Change in Laws and Regulations

37. Force Majeure
36.1 If, after the date 28 days prior to the date of Bid submission, in the country where the Site is located, any law, regulation, ordinance, order or by-law having the force of law is enacted, promulgated, abrogated, or changed, which shall be deemed to include any change in interpretation or application by the competent authorities, that subsequently affects the costs and expenses of the Contractor and/or the Time for Completion, the Contract Price shall be correspondingly increased or decreased, and/or the Time for Completion shall be reasonably adjusted to the extent that the Contractor has thereby been affected in the performance of any of its obligations under the Contract. Notwithstanding the foregoing, such additional or reduced costs shall not be separately paid or credited if the same has already been accounted for in the price adjustment provisions where applicable, in accordance with the SCC, pursuant to GCC Subclause 11.2.

37.1 "Force Majeure" shall mean any event beyond the reasonable control of the Employer or of the Contractor, as the case may be, and which is unavoidable notwithstanding the reasonable care of the party affected, and shall include, without limitation, the following:

(a) war, hostilities, or warlike operations whether a state of war be declared or not, invasion, act of foreign enemy and civil war;

(b) rebellion, revolution, insurrection, mutiny, usurpation of civil or military government, conspiracy, riot, civil commotion, and terrorist acts;

(c) confiscation, nationalization, mobilization, commandeering or requisition by or under the order of any government or de jure or de facto authority or ruler or any other act or failure to act of any local state or national government authority;

(d) strike, sabotage, lockout, embargo, import restriction, port congestion, lack of usual means of public transportation and communication, industrial dispute, shipwreck, shortage or restriction of power supply, epidemics, quarantine, and plague;

(e) earthquake, landslide, volcanic activity, fire, flood or inundation, tidal wave, typhoon or cyclone, hurricane, storm, lightning, or other inclement weather condition, nuclear, and pressure waves or other natural or physical disaster; and

(f) shortage of labor, materials, or utilities where caused by circumstances that are themselves Force Majeure.

37.2 If either party is prevented, hindered, or delayed from or in performing any of its obligations under the Contract by an event of Force Majeure, then it shall notify the other in writing of the occurrence of such event and the circumstances thereof within 14 days after the occurrence of such event. 
37.3 The party who has given such notice shall be excused from the performance or punctual performance of its obligations under the Contract for so long as the relevant event of Force Majeure continues and to the extent that such party's performance is prevented, hindered, or delayed. The Time for Completion shall be extended in accordance with GCC Clause 40.

37.4 The party or parties affected by the event of Force Majeure shall use reasonable efforts to mitigate the effect thereof upon its or their performance of the Contract and to fulfill its or their obligations under the Contract, but without prejudice to either party's right to terminate the Contract under GCC Subclauses 37.6 and 38.5.

37.5 No delay or nonperformance by either party hereto caused by the occurrence of any event of Force Majeure shall

(a) constitute a default or breach of the Contract; or

(b) give rise to any claim for damages or additional cost or expense occasioned thereby, subject to GCC Subclauses 32.2, 38.3, and 38.4

if and to the extent that such delay or nonperformance is caused by the occurrence of an event of Force Majeure.

37.6 If the performance of the Contract is substantially prevented, hindered, or delayed for a single period of more than 60 days or an aggregate period of more than 120 days on account of one or more events of Force Majeure during the currency of the Contract, the parties will attempt to develop a mutually satisfactory solution, failing which either party may terminate the Contract by giving a notice to the other, but without prejudice to either party's right to terminate the Contract under GCC Subclause 38.5.

37.7 In the event of termination pursuant to GCC Subclause 37.6, the rights and obligations of the Employer and the Contractor shall be as specified in GCC Subclauses 42.1.2 and 42.1.3.

37.8 Notwithstanding GCC Subclause 37.5, Force Majeure shall not apply to any obligation of the Employer to make payments to the Contractor herein.

38. War Risks

38.1 "War Risks" shall mean any event specified in paragraphs (a) and (b) of GCC Subclause 37.1 and any explosion or impact of any mine, bomb, shell, grenade, or other projectile, missile, munitions, or explosive of war, occurring or existing in or near the country (or countries) where the Site is located. 
38.2 Notwithstanding anything contained in the Contract, the Contractor shall have no liability whatsoever for or with respect to

(a) destruction of or damage to Facilities, Plant, or any part thereof;

(b) destruction of or damage to property of the Employer or any third party; or

(c) injury or loss of life

if such destruction, damage, injury or loss of life is caused by any war risks, and the Employer shall indemnify and hold the Contractor harmless from and against any and all claims, liabilities, actions, lawsuits, damages, costs, charges, or expenses arising in consequence of or in connection with the same.

38.3 If the Facilities or any Plant or Contractor's Equipment or any other property of the Contractor used or intended to be used for the purposes of the Facilities shall sustain destruction or damage by reason of any war risks, the Employer shall pay the Contractor for

(a) any part of the Facilities or the Plant so destroyed or damaged to the extent not already paid for by the Employer and so far as may be required by the Employer, and as may be necessary for completion of the Facilities;

(b) replacing or making good any Contractor's Equipment or other property of the Contractor so destroyed or damaged; and

(c) replacing or making good any such destruction or damage to the Facilities or the Plant or any part thereof.

If the Employer does not require the Contractor to replace or make good any such destruction or damage to the Facilities, the Employer shall either request a change in accordance with GCC Clause 39, excluding the performance of that part of the Facilities thereby destroyed or damaged or, where the loss, destruction, or damage affects a substantial part of the Facilities, shall terminate the Contract, pursuant to GCC Subclause 42.1.

If the Employer requires the Contractor to replace or make good on any such destruction or damage to the Facilities, the Time for Completion shall be extended in accordance with GCC 40.

38.4 Notwithstanding anything contained in the Contract, the Employer shall pay the Contractor for any increased costs or incidentals to the execution of the Contract that are in any way attributable to, consequent on, resulting from, or in any way connected with any war risks, provided that the Contractor shall as soon as practicable notify the Employer in writing of any such increased cost. 
38.5 If during the performance of the Contract any war risks shall occur that financially or otherwise materially affect the execution of the Contract by the Contractor, the Contractor shall use its reasonable efforts to execute the Contract with due and proper consideration given to the safety of its and its Subcontractors' personnel engaged in the work on the Facilities, provided, however, that if the execution of the work on the Facilities becomes impossible or is substantially prevented for a single period of more than sixty (60) days or an aggregate period of more than one hundred and twenty (120) days on account of any war risks, the parties will attempt to develop a mutually satisfactory solution, failing which either party may terminate the Contract by giving a notice to the other.

38.6 In the event of termination pursuant to GCC Subclauses 38.3 or 38.5, the rights and obligations of the Employer and the Contractor shall be specified in GCC Subclauses 42.1.2 and 42.1.3.

\section{H. Change in Contract Elements}

\section{Change in the Facilities}

\subsection{Introducing a Change}

39.1.1 Subject to GCC Subclauses 39.2.5 and 39.2.7, the Employer shall have the right to propose, and subsequently require, that the Project Manager order the Contractor from time to time during the performance of the Contract to make any change, modification, addition, or deletion to, in or from the Facilities hereinafter called "Change," provided that such Change falls within the general scope of the Facilities and does not constitute unrelated work and that it is technically practicable, taking into account both the state of advancement of the Facilities and the technical compatibility of the Change envisaged with the nature of the Facilities as specified in the Contract.

39.1.2 The Contractor may from time to time during its performance of the Contract propose to the Employer with a copy to the Project Manager, any Change that the Contractor considers necessary or desirable to improve the quality, efficiency, or safety of the Facilities. The Employer may at its discretion approve or reject any Change proposed by the Contractor, provided that the Employer shall approve any Change proposed by the Contractor to ensure the safety of the Facilities.

39.1.3 Notwithstanding GCC Subclauses 39.1.1 and 39.1.2, no change made necessary because of any default of the Contractor in the performance of its obligations under the Contract shall be deemed to be a Change, and such change shall not result in any adjustment of the Contract Price or the Time for Completion.

39.1.4 The procedure on how to proceed with and execute Changes is specified in GCC Subclauses 39.2 and 39.3, and further details and forms are provided in the Employer's Requirements (Forms and Procedures). 


\subsection{Changes Originating from Employer}

39.2.1 If the Employer proposes a Change pursuant to GCC Subclause 39.1.1, it shall send to the Contractor a "Request for Change Proposal," requiring the Contractor to prepare and furnish to the Project Manager as soon as reasonably practicable a "Change Proposal," which shall include the following:

(a) brief description of the Change,

(b) effect on the Time for Completion,

(c) estimated cost of the Change,

(d) effect on Functional Guarantees (if any),

(e) effect on the Facilities, and

(f) effect on any other provisions of the Contract.

39.2.2 Prior to preparing and submitting the "Change Proposal," the Contractor shall submit to the Project Manager an "Estimate for Change Proposal," which shall be an estimate of the cost of preparing and submitting the Change Proposal.

Upon receipt of the Contractor's Estimate for Change Proposal, the Employer shall do one of the following:

(a) accept the Contractor's estimate with instructions to the Contractor to proceed with the preparation of the Change Proposal,

(b) advise the Contractor of any part of its Estimate for Change Proposal that is unacceptable and request the Contractor to review its estimate,

(c) advise the Contractor that the Employer does not intend to proceed with the Change.

39.2.3 Upon receipt of the Employer's instruction to proceed under GCC Subclause 39.2.2(a), the Contractor shall, with proper expedition, proceed with the preparation of the Change Proposal, in accordance with GCC Subclause 39.2.1.

39.2.4 The pricing of any Change shall, as far as practicable, be calculated in accordance with the rates and prices included in the Contract. If such rates and prices are inequitable, the parties thereto shall agree on specific rates for the valuation of the Change. 
39.2.5 If before or during the preparation of the Change Proposal it becomes apparent that the aggregate effect of compliance therewith and with all other Change Orders that have already become binding upon the Contractor under this GCC Clause 39 would be to increase or decrease the Contract Price as originally set forth in Article 2 (Contract Price) of the Contract Agreement by more than $15 \%$, the Contractor may give a written notice of objection thereto prior to furnishing the Change Proposal as aforesaid. If the Employer accepts the Contractor's objection, the Employer shall withdraw the proposed Change and shall notify the Contractor in writing thereof.

The Contractor's failure to so object shall neither affect its right to object to any subsequent requested Changes or Change Orders herein, nor affect its right to take into account, when making such subsequent objection, the percentage increase or decrease in the Contract Price that any Change not objected to by the Contractor represents.

39.2.6 Upon receipt of the Change Proposal, the Employer and the Contractor shall mutually agree upon all matters therein contained. Within 14 days after such agreement, the Employer shall, if it intends to proceed with the Change, issue the Contractor with a Change Order.

If the Employer is unable to reach a decision within 14 days, it shall notify the Contractor with details of when the Contractor can expect a decision.

If the Employer decides not to proceed with the Change for whatever reason, it shall, within the said period of 14 days, notify the Contractor accordingly. Under such circumstances, the Contractor shall be entitled to reimbursement of all costs reasonably incurred by it in the preparation of the Change Proposal, provided that these do not exceed the amount given by the Contractor in its Estimate for Change Proposal submitted in accordance with GCC Subclause 39.2.2.

39.2.7 If the Employer and the Contractor cannot reach agreement on the price for the Change, an equitable adjustment to the Time for Completion, or any other matters identified in the Change Proposal, the Employer may nevertheless instruct the Contractor to proceed with the Change by issue of a "Pending Agreement Change Order."

Upon receipt of a Pending Agreement Change Order, the Contractor shall immediately proceed with effecting the Changes covered by such Order. The parties shall thereafter attempt to reach agreement on the outstanding issues under the Change Proposal. 
If the parties cannot reach agreement within 60 days from the date of issue of the Pending Agreement Change Order, then the matter may be referred to the Dispute Board in accordance with the provisions of GCC Subclause 45.3.

\subsection{Changes Originating from Contractor}

39.3.1 If the Contractor proposes a Change pursuant to GCC Subclause 39.1.2, the Contractor shall submit to the Project Manager a written "Application for Change Proposal," giving reasons for the proposed Change and including the information specified in GCC Subclause 39.2.1.

Upon receipt of the Application for Change Proposal, the parties shall follow the procedures outlined in GCC Subclauses 39.2.6 and 39.2.7. However, should the Employer choose not to proceed, the Contractor shall not be entitled to recover the costs of preparing the Application for Change Proposal.

40. Extension of Time for Completion
40.1 The Time(s) for Completion specified in the SCC shall be extended if the Contractor is delayed or impeded in the performance of any of its obligations under the Contract by reason of any of the following:

(a) any Change in the Facilities as provided in GCC Clause 39;

(b) any occurrence of Force Majeure as provided in GCC Clause 37, unforeseen conditions as provided in GCC Clause 35, or other occurrence of any of the matters specified or referred to in paragraphs (a), (b), and (c) of GCC Subclause 32.2;

(c) any suspension order given by the Employer under GCC Clause 41 hereof or reduction in the rate of progress pursuant to GCC Subclause 41.2; or

(d) any changes in laws and regulations as provided in GCC Clause 36; or

(e) any default or breach of the Contract by the Employer, or any activity, act, or omission of the Employer, or the Project Manager, or any other contractors employed by the Employer; or

(f) any other matter specifically mentioned in the Contract; or

(g) any delay on the part of a Subcontractor, provided such delay is due to a cause for which the Contractor himself would have been entitled to an extension of time under this Subclause

by such period as shall be fair and reasonable in all the circumstances and as shall fairly reflect the delay or impediment sustained by the Contractor. 
40.2 Except where otherwise specifically provided in the Contract, the Contractor shall submit to the Project Manager a notice of a claim for an extension of the Time for Completion, together with particulars of the event or circumstance justifying such extension as soon as reasonably practicable after the commencement of such event or circumstance. As soon as reasonably practicable after receipt of such notice and supporting particulars of the claim, the Employer and the Contractor shall agree upon the period of such extension. In the event that the Contractor does not accept the Employer's estimate of a fair and reasonable time extension, the Contractor shall be entitled to refer the matter to a Dispute Board, pursuant to GCC Subclause 45.3.

40.3 The Contractor shall at all times use its reasonable efforts to minimize any delay in the performance of its obligations under the Contract.

In all cases where the Contractor has given a notice of a claim for an extension of time under GCC 40.2, the Contractor shall consult with the Project Manager in order to determine the steps (if any) which can be taken to overcome or minimize the actual or anticipated delay. The Contractor shall there after comply with all reasonable instructions which the Project Manager shall give in order to minimize such delay. If compliance with such instructions shall cause the Contractor to incur extra costs and the Contractor is entitled to an extension of time under GCC 40.1, the amount of such extra costs shall be added to the Contract Price.

\section{Suspension}

41.1 The Employer may request the Project Manager, by notice to the Contractor, to order the Contractor to suspend performance of any or all of its obligations under the Contract. Such notice shall specify the obligation of which performance is to be suspended, the effective date of the suspension, and the reasons therefor. The Contractor shall thereupon suspend performance of such obligation, except those obligations necessary for the care or preservation of the Facilities, until ordered in writing to resume such performance by the Project Manager.

If, by virtue of a suspension order given by the Project Manager, other than by reason of the Contractor's default or breach of the Contract, the Contractor's performance of any of its obligations is suspended for an aggregate period of more than 90 days, then at any time thereafter and provided that at that time such performance is still suspended, the Contractor may give a notice to the Project Manager requiring that the Employer shall, within 28 days of receipt of the notice, order the resumption of such performance or request and subsequently order a change in accordance with GCC Clause 39, excluding the performance of the suspended obligations from the Contract.

If the Employer fails to do so within such period, the Contractor may, by a further notice to the Project Manager, elect to treat the suspension, where it affects a part only of the Facilities, as a deletion of such part in accordance with GCC Clause 39 or, where it affects the whole of the Facilities, as termination of the Contract under GCC Subclause 42.1. 
41.2 If

(a) the Employer has failed to pay the Contractor any sum due under the Contract within the specified period, has failed to approve any invoice or supporting documents without just cause pursuant to the Appendix (Terms and Procedures of Payment) to the Contract Agreement, or commits a substantial breach of the Contract, the Contractor may give a notice to the Employer that requires payment of such sum, with interest thereon as stipulated in GCC Subclause 12.3 , requires approval of such invoice or supporting documents, or specifies the breach and requires the Employer to remedy the same, as the case may be. If the Employer fails to pay such sum together with such interest, fails to approve such invoice or supporting documents, or give its reasons for withholding such approval, or fails to remedy the breach or take steps to remedy the breach within 14 days after receipt of the Contractor's notice; or

(b) the Contractor is unable to carry out any of its obligations under the Contract for any reason attributable to the Employer, including but not limited to the Employer's failure to provide possession of or access to the Site or other areas in accordance with GCC Subclause 10.2, or failure to obtain any governmental permit necessary for the execution and/or completion of the Facilities,

then the Contractor may by 14 days' notice to the Employer suspend performance of all or any of its obligations under the Contract, or reduce the rate of progress.

41.3 If the Contractor's performance of its obligations is suspended, or the rate of progress is reduced pursuant to this GCC Clause 41, then the Time for Completion shall be extended in accordance with GCC Subclause 40.1, and any and all additional costs or expenses incurred by the Contractor as a result of such suspension or reduction shall be paid by the Employer to the Contractor in addition to the Contract Price, except in the case of suspension order or reduction in the rate of progress by reason of the Contractor's default or breach of the Contract.

41.4 During the period of suspension, the Contractor shall not remove from the Site any Plant, any part of the Facilities or any Contractor's Equipment, without the prior written consent of the Employer. 
42. Termination

\subsection{Termination for Employer's Convenience}

42.1.1 The Employer may at any time terminate the Contract for any reason by giving the Contractor a notice of termination that refers to this GCC Subclause 42.1.

42.1.2 Upon receipt of the notice of termination under GCC Subclause 42.1.1, the Contractor shall, either immediately or upon the date specified in the notice of termination,

(a) cease all further work, except for such work as the Employer may specify in the notice of termination for the sole purpose of protecting that part of the Facilities already executed, or any work required to leave the Site in a clean and safe condition;

(b) terminate all subcontracts, except those to be assigned to the Employer pursuant to paragraph (d) (ii) below;

(c) remove all Contractor's Equipment from the Site, repatriate the Contractor's and its Subcontractors' personnel from the Site, remove from the Site any wreckage, rubbish, and debris of any kind, and leave the whole of the Site in a clean and safe condition; and

(d) subject to the payment specified in GCC Subclause 42.1.3,

(i) deliver to the Employer the parts of the Facilities executed by the Contractor up to the date of termination;

(ii) to the extent legally possible, assign to the Employer all right, title, and benefit of the Contractor to the Facilities and to the Plant as of the date of termination, and, as may be required by the Employer, in any subcontracts concluded between the Contractor and its Subcontractors; and

(iii) deliver to the Employer all nonproprietary drawings, specifications, and other documents prepared by the Contractor or its Subcontractors as at the date of termination in connection with the Facilities.

42.1.3 In the event of termination of the Contract under GCC Subclause 42.1.1, the Employer shall pay to the Contractor the following amounts:

(a) the Contract Price, properly attributable to the parts of the Facilities executed by the Contractor as of the date of termination;

(b) the costs reasonably incurred by the Contractor in the removal of the Contractor's Equipment from the Site and in the repatriation of the Contractor's and its Subcontractors' personnel; 
(c) any amounts to be paid by the Contractor to its Subcontractors in connection with the termination of any subcontracts, including any cancellation charges;

(d) costs incurred by the Contractor in protecting the Facilities and leaving the Site in a clean and safe condition pursuant to paragraph (a) of GCC Subclause 42.1.2; and

(e) the cost of satisfying all other obligations, commitments, and claims that the Contractor may in good faith have undertaken with third parties in connection with the Contract, and that are not covered by paragraphs (a) through (d) above.

\subsection{Termination for Contractor's Default}

42.2.1 The Employer, without prejudice to any other rights or remedies it may possess, may terminate the Contract forthwith in the following circumstances by giving a notice of termination and its reasons therefor to the Contractor, referring to this GCC Subclause 42.2:

(a) if the Contractor becomes bankrupt or insolvent, has a receiving order issued against it, compounds with its creditors, or, if the Contractor is a corporation, a resolution is passed or order is made for its winding up, other than a voluntary liquidation for the purposes of amalgamation or reconstruction, a receiver is appointed over any part of its undertaking or assets, or if the Contractor takes or suffers any other analogous action in consequence of debt;

(b) if the Contractor assigns or transfers the Contract or any right or interest therein in violation of the provision of GCC Clause 43; and

(c) if the Contractor, in the judgment of the Employer has engaged in integrity violations, as defined in GCC Clause 6, in competing for or in executing the Contract.

42.2.2 If the Contractor

(a) has abandoned or repudiated the Contract;

(b) has without valid reason failed to commence work on the Facilities promptly or has suspended, other than pursuant to GCC Subclause 41.2, the progress of Contract performance for more than 28 days after receiving a written instruction from the Employer to proceed;

(c) persistently fails to execute the Contract in accordance with the Contract or persistently neglects to carry out its obligations under the Contract without just cause; 
(d) refuses or is unable to provide sufficient materials, services, or labor to execute and complete the Facilities in the manner specified in the program furnished under GCC Subclause 18.2 at rates of progress that give reasonable assurance to the Employer that the Contractor can attain Completion of the Facilities by the Time for Completion as extended,

then the Employer may, without prejudice to any other rights it may possess under the Contract, give a notice to the Contractor, stating the nature of the default and requiring the Contractor to remedy the same. If the Contractor fails to remedy or to take steps to remedy the same within 14 days of its receipt of such notice, then the Employer may terminate the Contract forthwith by giving a notice of termination to the Contractor that refers to this GCC Subclause 42.2.

42.2.3 Upon receipt of the notice of termination under GCC Subclauses 42.2.1 or 42.2.2, the Contractor shall, either immediately or upon such date as is specified in the notice of termination,

(a) cease all further work, except for such work as the Employer may specify in the notice of termination for the sole purpose of protecting that part of the Facilities already executed, or any work required to leave the Site in a clean and safe condition;

(b) terminate all subcontracts, except those to be assigned to the Employer pursuant to paragraph (d);

(c) deliver to the Employer the parts of the Facilities executed by the Contractor up to the date of termination;

(d) to the extent legally possible, assign to the Employer all right, title and benefit of the Contractor to the Facilities and to the Plant as of the date of termination, and, as may be required by the Employer, in any subcontracts concluded between the Contractor and its Subcontractors; and

(e) deliver to the Employer all drawings, specifications, and other documents prepared by the Contractor or its Subcontractors as of the date of termination in connection with the Facilities.

42.2.4 The Employer may enter upon the Site, expel the Contractor, and complete the Facilities itself or by employing any third party. The Employer may, to the exclusion of any right of the Contractor over the same, take over and use with the payment of a fair rental rate to the Contractor, with all the maintenance costs to the account of the Employer and with an indemnification by the Employer for all liability including damage or injury to persons arising out of the Employer's use of such equipment, any Contractor's Equipment owned by the Contractor and on the Site in connection with the Facilities for such reasonable period as the Employer considers expedient for the supply and installation of the Facilities. 
Upon completion of the Facilities or at such earlier date as the Employer thinks appropriate, the Employer shall give notice to the Contractor that such Contractor's Equipment will be returned to the Contractor at or near the Site and shall return such Contractor's Equipment to the Contractor in accordance with such notice. The Contractor shall thereafter without delay and at its cost remove or arrange removal of the same from the Site.

42.2.5 Subject to GCC Subclause 42.2.6, the Contractor shall be entitled to be paid the Contract Price attributable to the Facilities executed as of the date of termination, the value of any unused or partially used Plant on the Site, and the costs, if any, incurred in protecting the Facilities and in leaving the Site in a clean and safe condition pursuant to paragraph (a) of GCC Subclause 42.2.3. Any sums due the Employer from the Contractor accruing prior to the date of termination shall be deducted from the amount to be paid to the Contractor under this Contract.

42.2.6 If the Employer completes the Facilities, the cost of completing the Facilities by the Employer shall be determined.

If the sum that the Contractor is entitled to be paid, pursuant to GCC Subclause 42.2.5, plus the reasonable costs incurred by the Employer in completing the Facilities, exceeds the Contract Price, the Contractor shall be liable for such excess.

If such excess is greater than the sums due the Contractor under GCC Subclause 42.2.5, the Contractor shall pay the balance to the Employer, and if such excess is less than the sums due the Contractor under GCC Subclause 42.2.5, the Employer shall pay the balance to the Contractor.

The Employer and the Contractor shall agree, in writing, on the computation described above and the manner in which any sums shall be paid. 


\subsection{Termination by Contractor}

\subsubsection{If}

(a) the Employer has failed to pay the Contractor any sum due under the Contract within the specified period, has failed to approve any invoice or supporting documents without just cause pursuant to the Appendix (Terms and Procedures of Payment) to the Contract Agreement, or commits a substantial breach of the Contract, the Contractor may give a notice to the Employer that requires payment of such sum, with interest thereon as stipulated in GCC Subclause 12.3, requires approval of such invoice or supporting documents, or specifies the breach and requires the Employer to remedy the same, as the case may be. If the Employer fails to pay such sum together with such interest, fails to approve such invoice or supporting documents or give its reasons for withholding such approval, fails to remedy the breach or take steps to remedy the breach within 14 days after receipt of the Contractor's notice; or

(b) the Contractor is unable to carry out any of its obligations under the Contract for any reason attributable to the Employer, including but not limited to the Employer's failure to provide possession of or access to the Site or other areas or failure to obtain any governmental permit necessary for the execution and/or completion of the Facilities,

then the Contractor may give a notice to the Employer thereof, and if the Employer has failed to pay the outstanding sum, to approve the invoice or supporting documents, to give its reasons for withholding such approval, or to remedy the breach within 28 days of such notice, or if the Contractor is still unable to carry out any of its obligations under the Contract for any reason attributable to the Employer within 28 days of the said notice, the Contractor may by a further notice to the Employer referring to this GCC Subclause 42.3.1, forthwith terminate the Contract.

42.3.2 The Contractor may terminate the Contract forthwith by giving a notice to the Employer to that effect, referring to this GCC Subclause 42.3.2, if the Employer becomes bankrupt or insolvent, has a receiving order issued against it, compounds with its creditors, or, being a corporation, if a resolution is passed or order is made for its winding up (other than a voluntary liquidation for the purposes of amalgamation or reconstruction), a receiver is appointed over any part of its undertaking or assets, or if the Employer takes or suffers any other analogous action in consequence of debt. 
42.3.3 If the Contract is terminated under GCC Subclauses 42.3.1 or 42.3.2, then the Contractor shall immediately

(a) cease all further work, except for such work as may be necessary for the purpose of protecting that part of the Facilities already executed, or any work required to leave the Site in a clean and safe condition;

(b) terminate all subcontracts, except those to be assigned to the Employer pursuant to paragraph (d) (ii);

(c) remove all Contractor's Equipment from the Site and repatriate the Contractor's and its Subcontractors' personnel from the Site; and

(d) subject to the payment specified in GCC Subclause 42.3.4,

(i) deliver to the Employer the parts of the Facilities executed by the Contractor up to the date of termination;

(ii) to the extent legally possible, assign to the Employer all right, title, and benefit of the Contractor to the Facilities and to the Plant as of the date of termination, and, as may be required by the Employer, in any subcontracts concluded between the Contractor and its Subcontractors; and

(iii) deliver to the Employer all drawings, specifications, and other documents prepared by the Contractor or its Subcontractors as of the date of termination in connection with the Facilities.

42.3.4 If the Contract is terminated under GCC Subclauses 42.3.1 or 42.3.2, the Employer shall pay to the Contractor all payments specified in GCC Subclause 42.1.3, and reasonable compensation for all loss, except for loss of profit, or damage sustained by the Contractor arising out of, in connection with or in consequence of such termination.

42.3.5 Termination by the Contractor pursuant to this GCC Subclause 42.3 is without prejudice to any other rights or remedies of the Contractor that may be exercised in lieu of or in addition to rights conferred by GCC Subclause 42.3.

42.4 In this GCC Clause 42, the expression "Facilities executed" shall include all work executed, Installation Services provided, and all Plant acquired, or subject to a legally binding obligation to purchase, by the Contractor and used or intended to be used for the purpose of the Facilities, up to and including the date of termination.

42.5 In this GCC Clause 42, in calculating any monies due from the Employer to the Contractor, account shall be taken of any sum previously paid by the Employer to the Contractor under the Contract, including any advance payment paid pursuant to the Appendix (Terms and Procedures of Payment) to the Contract Agreement. 
43. Assignment

43.1 Neither the Employer nor the Contractor shall, without the express prior written consent of the other party which consent shall not be unreasonably withheld, assign to any third party the Contract or any part thereof, or any right, benefit, obligation, or interest therein or thereunder, except that the Contractor shall be entitled to assign either absolutely or by way of charge any monies due and payable to it or that may become due and payable to it under the Contract.

\section{Claims, Disputes, and Arbitration}

\section{Contractor's Claims}

44.1 If the Contractor considers himself to be entitled to any extension of the Time for Completion and/or any additional payment, under any Clause of these Conditions or otherwise in connection with the Contract, the Contractor shall submit a notice to the Project Manager, describing the event or circumstance giving rise to the claim. The notice shall be given as soon as practicable, and not later than 28 days after the Contractor became aware, or should have become aware, of the event or circumstance.

If the Contractor fails to give notice of a claim within such period of 28 days, the Time for Completion shall not be extended, the Contractor shall not be entitled to additional payment, and the Employer shall be discharged from all liability in connection with the claim. Otherwise, the following provisions of this Subclause shall apply.

The Contractor shall also submit any other notices which are required by the Contract, and supporting particulars for the claim, all as relevant to such event or circumstance.

The Contractor shall keep such contemporary records as may be necessary to substantiate any claim, either on the Site or at another location acceptable to the Project Manager. Without admitting the Employer's liability, the Project Manager may, after receiving any notice under this Subclause, monitor the record keeping and/or instruct the Contractor to keep further contemporary records. The Contractor shall permit the Project Manager to inspect all these records, and shall (if instructed) submit copies to the Project Manager.

Within 42 days after the Contractor became aware (or should have become aware) of the event or circumstance giving rise to the claim, or within such other period as may be proposed by the Contractor and approved by the Project Manager, the Contractor shall send to the Project Manager a fully detailed claim which includes full supporting particulars of the basis of the claim and of the extension of time and/or additional payment claimed. If the event or circumstance giving rise to the claim has a continuing effect,

(a) this fully detailed claim shall be considered as interim;

(b) the Contractor shall send further interim claims at monthly intervals, giving the accumulated delay and/or amount claimed, and such further particulars as the Project Manager may reasonably require; and 
(c) the Contractor shall send a final claim within 28 days after the end of the effects resulting from the event or circumstance, or within such other period as may be proposed by the Contractor and approved by the Project Manager.

Within 42 days after receiving a claim or any further particulars supporting a previous claim, or within such other period as may be proposed by the Project Manager and approved by the Contractor, the Project Manager shall respond with approval, or with disapproval and detailed comments. He may also request any necessary further particulars, but shall nevertheless give his response on the principles of the claim within such time.

Each payment certificate shall include such amounts for any claim as have been reasonably substantiated as due under the relevant provision of the Contract. Unless and until the particulars supplied are sufficient to substantiate the whole of the claim, the Contractor shall only be entitled to payment for such part of the claim as he has been able to substantiate.

The Project Manager shall agree with the Contractor or estimate (i) the extension (if any) of the Time for Completion (before or after its expiry) in accordance with GCC Clause 40, and/or (ii) the additional payment (if any) to which the Contractor is entitled under the Contract.

The requirements of this Subclause are in addition to those of any other Subclause which may apply to a claim. If the Contractor fails to comply with this or another Subclause in relation to any claim, any extension of time and/or additional payment shall take account of the extent (if any) to which the failure has prevented or prejudiced proper investigation of the claim, unless the claim is excluded under the second paragraph of this Subclause.

In the event that the Contractor and the Employer cannot agree on any matter relating to a claim, either party may refer the matter to the Dispute Board pursuant to GCC 45.3 hereof.

\section{Disputes and Arbitration}

\subsection{Appointment of the Dispute Board}

Disputes shall be referred to a Dispute Board for decision in accordance with GCC Subclause 45.3. The Parties shall appoint a Dispute Board by the date stated in the SCC.

The Dispute Board shall comprise, as stated in the SCC, either one or three suitably qualified persons ("the members"), each of whom shall be fluent in the language for communication defined in the Contract and shall be a professional experienced in the type of activities involved in the performance of the Contract and with the interpretation of contractual documents. If the number is not so stated and the Parties do not agree otherwise, the Dispute Board shall comprise three persons, one of whom shall serve as chairman. 
If the Parties have not jointly appointed the Dispute Board 21 days before the date stated in the SCC and the Dispute Board is to comprise three persons, each Party shall nominate one member for the approval of the other Party. The first two members shall recommend and the Parties shall agree upon the third member, who shall act as chairman.

However, if a list of potential members is included in the SCC, the members shall be selected from those on the list, other than anyone who is unable or unwilling to accept appointment to the Dispute Board.

The agreement between the Parties and either the sole member or each of the three members shall incorporate by reference the General Conditions of Dispute Board Agreement contained in the Appendix to these General Conditions, with such amendments as are agreed between them.

The terms of the remuneration of either the sole member or each of the three members, including the remuneration of any expert whom the Dispute Board consults, shall be mutually agreed upon by the Parties when agreeing the terms of appointment of the member or such expert (as the case may be). Each Party shall be responsible for paying one-half of this remuneration.

If a member declines to act or is unable to act as a result of death, disability, resignation, or termination of appointment, a replacement shall be appointed in the same manner as the replaced person was required to have been nominated or agreed upon, as described in this Subclause.

The appointment of any member may be terminated by mutual agreement of both Parties, but not by the Employer or the Contractor acting alone. Unless otherwise agreed by both Parties, the appointment of the Dispute Board (including each member) shall expire when the Operational Acceptance Certificate has been issued in accordance with GCC Clause 25.3.

\subsection{Failure to Agree Dispute Board}

If any of the following conditions apply, namely:

(a) the Parties fail to agree upon the appointment of the sole member of the Dispute Board by the date stated in the first paragraph of GCC Subclause 45.1;

(b) either Party fails to nominate a member (for approval by the other Party) of a Dispute Board of three persons by such date;

(c) the Parties fail to agree upon the appointment of the third member (to act as chairman) of the Dispute Board by such date; 
(d) the Parties fail to agree upon the appointment of a replacement person within 42 days after the date on which the sole member or one of the three members declines to act or is unable to act as a result of death, disability, resignation, or termination of appointment,

then the appointing entity or official named in the SCC shall, upon the request of either or both of the Parties and after due consultation with both Parties, appoint this member of the Dispute Board. This appointment shall be final and conclusive. Each Party shall be responsible for paying one-half of the remuneration of the appointing entity or official.

\subsection{Obtaining Dispute Board's Decision}

If a dispute (of any kind whatsoever) arises between the Parties in connection with the performance of the Contract, including any dispute as to any certificate, determination, instruction, opinion, or valuation of the Project Manager, either Party may refer the dispute in writing to the Dispute Board for its decision, with copies to the other Party and the Project Manager. Such reference shall state that it is given under this Subclause.

For a Dispute Board of three persons, the Dispute Board shall be deemed to have received such reference on the date when it is received by the chairman of the Dispute Board.

Both Parties shall promptly make available to the Dispute Board all such additional information, further access to the Site, and appropriate facilities, as the Dispute Board may require for the purposes of making a decision on such dispute. The Dispute Board shall be deemed to be not acting as arbitrator(s).

Within 84 days after receiving such reference, or within such other period as may be proposed by the Dispute Board and approved by both Parties, the Dispute Board shall give its decision, which shall be reasoned and shall state that it is given under this Subclause. The decision shall be binding on both Parties, who shall promptly give effect to it unless and until it shall be revised in an amicable settlement or an arbitral award as described below. Unless the Contract has already been abandoned, repudiated, or terminated, the Contractor shall continue to proceed with the performance of the Facilities in accordance with the Contract.

If either Party is dissatisfied with the Dispute Board's decision, then either Party may, within 28 days after receiving the decision, give notice to the other Party of its dissatisfaction and intention to commence arbitration. If the Dispute Board fails to give its decision within the period of 84 days (or as otherwise approved) after receiving such reference, then either Party may, within 28 days after this period has expired, give notice to the other Party of its dissatisfaction and intention to commence arbitration. 
In either event, this notice of dissatisfaction shall state that it is given under this Subclause, and shall set out the matter in dispute and the reason(s) for dissatisfaction. Except as stated in GCC Subclauses 45.6 and 45.7, neither Party shall be entitled to commence arbitration of a dispute unless a notice of dissatisfaction has been given in accordance with this Subclause.

If the Dispute Board has given its decision as to a matter in dispute to both Parties, and no notice of dissatisfaction has been given by either Party within 28 days after it received the Dispute Board's decision, then the decision shall become final and binding upon both Parties.

\subsection{Amicable Settlement}

Where notice of dissatisfaction has been given under GCC Subclause 45.3 above, both Parties shall attempt to settle the dispute amicably before the commencement of arbitration. However, unless both Parties agree otherwise, arbitration may be commenced on or after the 56th day after the day on which notice of dissatisfaction and intention to commence arbitration was given, even if no attempt at amicable settlement has been made.

\subsection{Arbitration}

Unless settled amicably, any dispute in respect of which the Dispute Board's decision (if any) has not become final and binding shall be finally settled by international arbitration. Unless otherwise agreed by both Parties,

(a) arbitration proceedings shall be conducted as stated in the Special Conditions;

(b) if no arbitration proceedings is so stated, the dispute shall be finally settled by institutional arbitration under the Rules of Arbitration of the International Chamber of Commerce;

(c) the dispute shall be settled by three arbitrators; and

(d) the arbitration shall be conducted in the language for communications defined in GCC Subclause 5.3.

The arbitrator(s) shall have full power to open up, review, and revise any certificate, determination, instruction, opinion, or valuation of the Project Manager, and any decision of the Dispute Board, relevant to the dispute. Nothing shall disqualify the Project Manager from being called as a witness and giving evidence before the arbitrator(s) on any matter whatsoever relevant to the dispute.

Neither Party shall be limited in the proceedings before the arbitrator(s) to the evidence or arguments previously put before the Dispute Board to obtain its decision, or to the reasons for dissatisfaction given in its notice of dissatisfaction. Any decision of the Dispute Board shall be admissible in evidence in the arbitration. 
Arbitration may be commenced prior to or after completion of the Works. The obligations of the Parties, the Project Manager, and the Dispute Board shall not be altered by reason of any arbitration being conducted during the progress of the Works.

\subsection{Failure to Comply with Dispute Board's Decision}

In the event that a Party fails to comply with a Dispute Board decision which has become final and binding, then the other Party may, without prejudice to any other rights it may have, refer the failure itself to arbitration under GCC Subclause 45.5. GCC Subclauses 45.3 and 45.4 shall not apply to this reference.

\subsection{Expiry of Dispute Board's Appointment}

If a dispute arises between the Parties in connection with the performance of the Contract, and there is no Dispute Board in place, whether by reason of the expiry of the Dispute Board's appointment or otherwise,

(a) GCC Subclauses 45.3 and 45.4 shall not apply, and

(b) the dispute may be referred directly to arbitration under GCC Subclause 45.5. 


\section{Appendix A}

\section{General Conditions of Dispute Board Agreement}

\section{Definitions}

Each "Dispute Board Agreement" is a tripartite agreement by and between:

(a) the "Employer";

(b) the "Contractor"; and

(c) the "Member" who is defined in the Dispute Board Agreement as being:

(i) the sole member of the "Dispute Board" and, where this is the case, all references to the "Other Members" do not apply; or

(ii) one of the three persons who are jointly called the "Dispute Board" (or "dispute board") and, where this is the case, the other two persons are called the "Other Members".

The Employer and the Contractor have entered (or intend to enter) into a contract, which is called the "Contract" and is defined in the Dispute Board Agreement, which incorporates this Appendix. In the Dispute Board Agreement, words and expressions which are not otherwise defined shall have the meanings assigned to them in the Contract.

\section{General Provisions}

Unless otherwise stated in the Dispute Board Agreement, it shall take effect on the latest of the following dates:

(a) the Commencement Date defined in the Contract;

(b) when the Employer, the Contractor, and the Member have each signed the Dispute Board Agreement; or

(c) when the Employer, the Contractor, and each of the Other Members (if any) have respectively each signed a dispute board agreement.

This employment of the Member is a personal appointment. At any time, the Member may give not less than 70 days' notice of resignation to the Employer and to the Contractor, and the Dispute Board Agreement shall terminate upon the expiry of this period.

\section{Warranties}

The Member warrants and agrees that he/she is and shall be impartial and independent of the Employer, the Contractor, and the Project Manager. The Member shall promptly disclose, to each of them and to the Other Members (if any), any fact or circumstance which might appear inconsistent with his/her warranty and agreement of impartiality and independence. 
When appointing the Member, the Employer and the Contractor relied upon the Member's representations that he/she is:

(a) experienced in the work, which the Contractor is to carry out under the Contract,

(b) experienced in the interpretation of contract documentation, and

(c) fluent in the language for communications defined in the Contract.

\section{General Obligations of the Member}

The Member shall:

(a) have no interest financial or otherwise in the Employer, the Contractor, or the Project Manager, nor any financial interest in the Contract except for payment under the Dispute Board Agreement;

(b) not previously have been employed as a consultant or otherwise by the Employer, the Contractor, or the Project Manager, except in such circumstances as were disclosed in writing to the Employer and the Contractor before they signed the Dispute Board Agreement;

(c) have disclosed in writing to the Employer, the Contractor, and the Other Members (if any), before entering into the Dispute Board Agreement and to his/her best knowledge and recollection, any professional or personal relationships with any director, officer, or employee of the Employer, the Contractor, or the Project Manager, and any previous involvement in the overall project of which the Contract forms part;

(d) not, for the duration of the Dispute Board Agreement, be employed as a consultant or otherwise by the Employer, the Contractor, or the Project Manager, except as may be agreed in writing by the Employer, the Contractor, and the Other Members (if any);

(e) comply with the annexed procedural rules and with GCC Subclause 45.1;

(f) not give advice to the Employer, the Contractor, the Employer's Personnel, or the Contractor's Personnel concerning the conduct of the Contract, other than in accordance with the annexed procedural rules;

(g) not while a Member enter into discussions or make any agreement with the Employer, the Contractor, or the Project Manager regarding employment by any of them, whether as a consultant or otherwise, after ceasing to act under the Dispute Board Agreement;

(h) ensure his/her availability for all site visits and hearings as are necessary;

(i) become conversant with the Contract and with the progress of the Facilities (and of any other parts of the project of which the Contract forms part) by studying all documents received, which shall be maintained in a current working file;

(j) treat the details of the Contract and all the Dispute Board's activities and hearings as private and confidential, and not publish or disclose them without the prior written consent of the Employer, the Contractor, and the Other Members (if any); and

(k) be available to give advice and opinions on any matter relevant to the Contract when requested by both the Employer and the Contractor, subject to the agreement of the Other Members (if any). 


\section{General Obligations of the Employer and the Contractor}

The Employer, the Contractor, the Employer's Personnel, and the Contractor's Personnel shall not request advice from or consultation with the Member regarding the Contract, otherwise than in the normal course of the Dispute Board's activities under the Contract and the Dispute Board Agreement. The Employer and the Contractor shall be responsible for compliance with this provision, by the Employer's Personnel and the Contractor's Personnel respectively.

The Employer and the Contractor undertake to each other and to the Member that the Member shall not, except as otherwise agreed in writing by the Employer, the Contractor, the Member, and the Other Members (if any),

(a) be appointed as an arbitrator in any arbitration under the Contract;

(b) be called as a witness to give evidence concerning any dispute before arbitrator(s) appointed for any arbitration under the Contract; or

(c) be liable for any claims for anything done or omitted in the discharge or purported discharge of the Member's functions, unless the act or omission is shown to have been in bad faith.

The Employer and the Contractor hereby jointly and severally indemnify and hold the Member harmless against and from claims from which he is relieved from liability under the preceding paragraph.

Whenever the Employer or the Contractor refers a dispute to the Dispute Board under GCC Subclause 45.3, which will require the Member to make a site visit and attend a hearing, the Employer or the Contractor shall provide appropriate security for a sum equivalent to the reasonable expenses to be incurred by the Member. No account shall be taken of any other payments due or paid to the Member.

\section{Payment}

The Member shall be paid as follows, in the currency named in the Dispute Board Agreement:

(a) a retainer fee per calendar month, which shall be considered as payment in full for:

(i) being available on 28 days' notice for all site visits and hearings;

(ii) becoming and remaining conversant with all project developments and maintaining relevant files;

(iii) all office and overhead expenses including secretarial services, photocopying, and office supplies incurred in connection with his duties; and

(iv) all services performed hereunder except those referred to in subparagraphs (b) and (c) of this Clause.

The retainer fee shall be paid with effect from the last day of the calendar month in which the Dispute Board Agreement becomes effective; until the last day of the calendar month in which the Taking-Over Certificate is issued for the whole of the Works.

With effect from the first day of the calendar month following the month in which Taking-Over Certificate is issued for the whole of the Works, the retainer fee shall be reduced by one-third. This reduced fee shall be paid until the first day of the calendar month in which the Member resigns or the Dispute Board Agreement is otherwise terminated. 
(b) a daily fee, which shall be considered as payment in full for

(i) each day or part of a day up to a maximum of 2 days' travel time in each direction for the journey between the Member's home and the site, or another location of a meeting with the Other Members (if any);

(ii) each working day on site visits, hearings, or preparing decisions; and

(iii) each day spent reading submissions in preparation for a hearing.

(c) all reasonable expenses, including necessary travel expenses (air fare in less than first class, hotel, and subsistence and other direct travel expenses) incurred in connection with the Member's duties, as well as the cost of telephone calls, courier charges, facsimiles, telexes, and use of the internet: a receipt shall be required for each item in excess of $5 \%$ of the daily fee referred to in subparagraph (b) of this Clause;

(d) any taxes properly levied in the Country on payments made to the Member (unless a national or permanent resident of the Country) under this Clause 6.

The retainer and daily fees shall be as specified in the Dispute Board Agreement. Unless it specifies otherwise, these fees shall remain fixed for the first 24 calendar months, and shall thereafter be adjusted by agreement between the Employer, the Contractor, and the Member, at each anniversary of the date on which the Dispute Board Agreement became effective.

If the parties fail to agree on the retainer fee or the daily fee, the appointing entity or official named in the SCC shall determine the amount of the fees to be used.

The Member shall submit invoices for payment of the monthly retainer and air fares quarterly in advance. Invoices for other expenses and for daily fees shall be submitted following the conclusion of a site visit or hearing. All invoices shall be accompanied by a brief description of activities performed during the relevant period and shall be addressed to the Contractor.

The Contractor shall pay each of the Member's invoices in full within 56 calendar days after receiving each invoice and shall apply to the Employer (in the Statements under the Contract) for reimbursement of one-half of the amounts of these invoices. The Employer shall then pay the Contractor in accordance with the Contract.

If the Contractor fails to pay to the Member the amount to which he/she is entitled under the Dispute Board Agreement, the Employer shall pay the amount due to the Member and any other amount which may be required to maintain the operation of the Dispute Board; and without prejudice to the Employer's rights or remedies. In addition to all other rights arising from this default, the Employer shall be entitled to reimbursement of all sums paid in excess of one-half of these payments, plus all costs of recovering these sums and financing charges calculated the rate specified in accordance with GCC Subclause 12.3.

If the Member does not receive payment of the amount due within 70 days after submitting a valid invoice, the Member may (i) suspend his/her services (without notice) until the payment is received, and/or (ii) resign his/her appointment by giving notice under Clause 7. 


\section{Termination}

At any time: (i) the Employer and the Contractor may jointly terminate the Dispute Board Agreement by giving 42 days' notice to the Member, or (ii) the Member may resign as provided for in Clause 2.

If the Member fails to comply with the Dispute Board Agreement, the Employer and the Contractor may, without prejudice to their other rights, terminate it by notice to the Member. The notice shall take effect when received by the Member.

If the Employer or the Contractor fails to comply with the Dispute Board Agreement, the Member may, without prejudice to his other rights, terminate it by notice to the Employer and the Contractor. The notice shall take effect when received by them both.

Any such notice, resignation, and termination shall be final and binding on the Employer, the Contractor, and the Member. However, a notice by the Employer or the Contractor, but not by both, shall be of no effect.

\section{Default of the Member}

If the Member fails to comply with any of his obligations under Clause 4 concerning his impartiality or independence in relation to the Employer or the Contractor, he/she shall not be entitled to any fees or expenses hereunder and shall, without prejudice to their other rights, reimburse each of the Employer and the Contractor for any fees and expenses received by the Member and the Other Members (if any), for proceedings or decisions (if any) of the Dispute Board are rendered void or ineffective by the said failure to comply.

\section{Disputes}

Any dispute or claim arising out of or in connection with this Dispute Board Agreement, or the breach, termination, or invalidity thereof, shall be finally settled by institutional arbitration. If no other arbitration institute is agreed, the arbitration shall be conducted under the Rules of Arbitration of the International Chamber of Commerce by one arbitrator appointed in accordance with these Rules of Arbitration. 


\section{Annex - Dispute Board Guidelines}

1. Unless otherwise agreed by the Employer and the Contractor, the Dispute Board shall visit the site at intervals of not more than 140 days, including times of critical construction events, at the request of either the Employer or the Contractor. Unless otherwise agreed by the Employer, the Contractor, and the Dispute Board, the period between consecutive visits shall not be less than 70 days, except as required to convene a hearing as described below.

2. The timing of and agenda for each site visit shall be as agreed jointly by the Dispute Board, the Employer, and the Contractor, or in the absence of agreement, shall be decided by the Dispute Board. The purpose of site visits is to enable the Dispute Board to become and remain acquainted with the progress of the Works and of any actual or potential problems or claims, and, as far as reasonable, to prevent potential problems or claims from becoming disputes.

3. Site visits shall be attended by the Employer, the Contractor, and the Project Manager and shall be coordinated by the Employer in cooperation with the Contractor. The Employer shall ensure the provision of appropriate conference facilities and secretarial and copying services. At the conclusion of each site visit and before leaving the site, the Dispute Board shall prepare a report on its activities during the visit and shall send copies to the Employer and the Contractor.

4. The Employer and the Contractor shall furnish to the Dispute Board one copy of all documents which the Dispute Board may request, including Contract documents, progress reports, variation instructions, certificates, and other documents pertinent to the performance of the Contract. All communications between the Dispute Board and the Employer or the Contractor shall be copied to the other Party. If the Dispute Board comprises three persons, the Employer and the Contractor shall send copies of these requested documents and these communications to each of these persons.

5. If any dispute is referred to the Dispute Board in accordance with GCC Subclause 45.3, the Dispute Board shall proceed in accordance with GCC Subclause 45.3 and these Guidelines. Subject to the time allowed to give notice of a decision and other relevant factors, the Dispute Board shall:

(a) act fairly and impartially as between the Employer and the Contractor, giving each of them a reasonable opportunity of putting his case and responding to the other's case; and

(b) adopt procedures suitable to the dispute, avoiding unnecessary delay or expense.

6. The Dispute Board may conduct a hearing on the dispute, in which event it will decide on the date and place for the hearing and may request that written documentation and arguments from the Employer and the Contractor be presented to it prior to or at the hearing.

7. Except as otherwise agreed in writing by the Employer and the Contractor, the Dispute Board shall have power to adopt an inquisitorial procedure, to refuse admission to hearings or audience at hearings to any persons other than representatives of the Employer, the Contractor, and the Project Manager, and to proceed in the absence of any party who the Dispute Board is satisfied received notice of the hearing; but shall have discretion to decide whether and to what extent this power may be exercised.

8. The Employer and the Contractor empower the Dispute Board, among other things, to:

(a) establish the procedure to be applied in deciding a dispute;

(b) decide upon the Dispute Board's own jurisdiction, and as to the scope of any dispute referred to it; 
(c) conduct any hearing as it thinks fit, not being bound by any rules or procedures other than those contained in the Contract and these Guidelines;

(d) take the initiative in ascertaining the facts and matters required for a decision;

(e) make use of its own specialist knowledge, if any;

(f) decide upon the payment of financing charges in accordance with the Contract;

(g) decide upon any provisional relief such as interim or conservatory measures;

(h) open up, review, and revise any certificate, decision, determination, instruction, opinion, or valuation of the Project Manager, relevant to the dispute; and

(i) appoint, should the Dispute Board so consider necessary and the Parties agree, a suitable expert at the cost of the Parties to give advice on a specific matter relevant to the dispute.

9. The Dispute Board shall not express any opinions during any hearing concerning the merits of any arguments advanced by the Parties. Thereafter, the Dispute Board shall make and give its decision in accordance with GCC Subclause 45.3, or as otherwise agreed by the Employer and the Contractor in writing. If the Dispute Board comprises three persons,

(a) it shall convene in private after a hearing, in order to have discussions and prepare its decision;

(b) it shall endeavour to reach a unanimous decision: if this proves impossible, the applicable decision shall be made by a majority of the Members, who may require the minority Member to prepare a written report for submission to the Employer and the Contractor; and

(c) if a Member fails to attend a meeting or hearing, or to fulfil any required function, the other two Members may nevertheless proceed to make a decision, unless:

(i) either the Employer or the Contractor does not agree that they do so, or

(ii) the absent Member is the chairman and he/she instructs the other Members to not make a decision. 


\section{Section 8: Special Conditions of Contract}

The following Special Conditions of Contract (SCC) shall supplement the General Conditions of Contract (GCC). Whenever there is a conflict, the provisions herein shall prevail over those in the GCC. The clause numbers of the SCC correspond to the clause number of the GCC.

\section{Table of Clauses}

1. Definitions

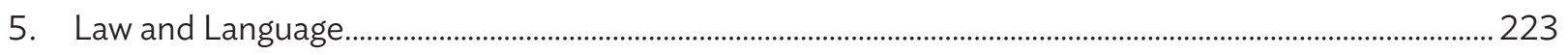

6. Fraud and Corruption ......................................................................................................................................22

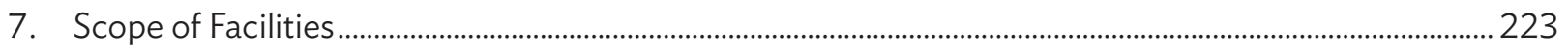

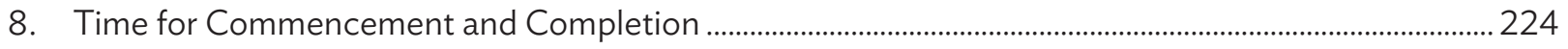

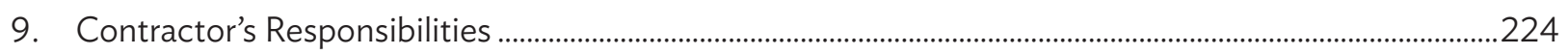

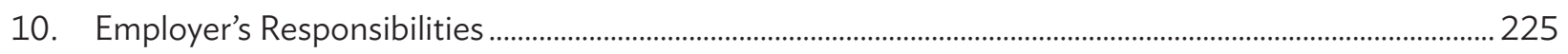

11. Contract Price ............................................................................................................................................................. 225

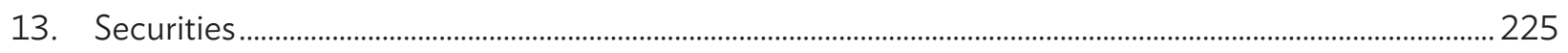

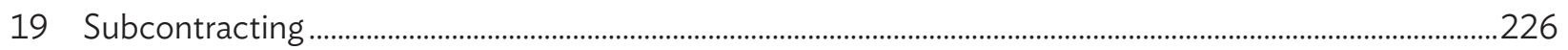

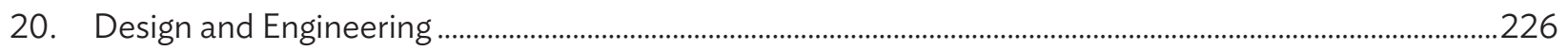

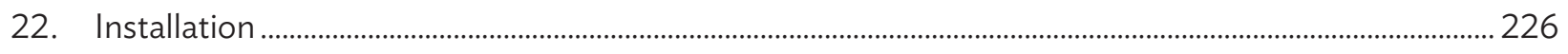

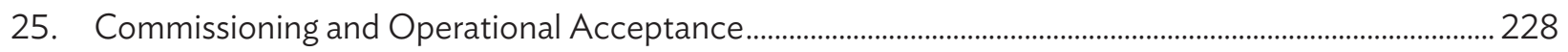

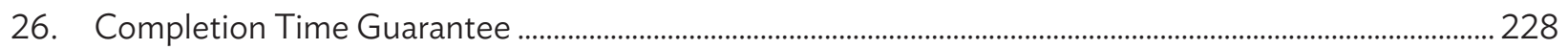

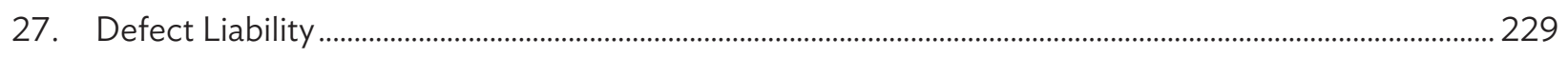

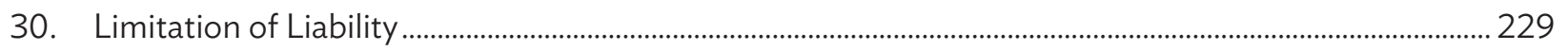

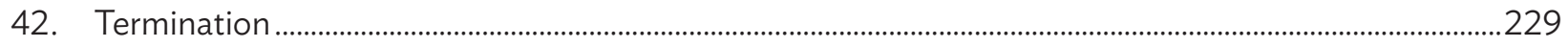

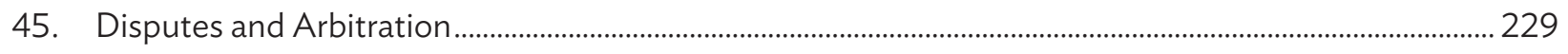

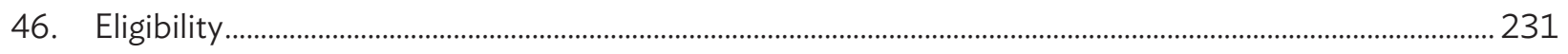




\section{Definitions}

The Employer is: [insert Employer's name and address as indicated in the BDS]

[The Employer should be the Executing Agency/Implementing Agency named in the Financing Agreement or the entity authorized to carry out the procurement activities under the Project Administration Manual]

The Project Manager is: [insert project manager's name] The Bank is: [Asian Development Bank]

Country of Origin: [insert most recent list of eligible countries as specified in Article 1.1(d) of Contract Agreement]

\section{Law and Language}

5.1 The Contract shall be interpreted in accordance with the laws of: [insert name of the Employer's country]

5.2 The ruling language is: [insert "the English language"]

5.3 The language for communications is: [insert "the English language"]

\section{Fraud and Corruption}

6.4 The Contractor has the obligation to notify the Employer of any changes in connection with the matters described in paragraphs (i), (k), (I), (m), (n), (o), (p) and (t) of the Letter of Bid.

\section{NOTE}

For Two-Stage Bidding Procedure, please replace with the following.

The Contractor has the obligation to notify the Employer of any changes in connection with the matters described in paragraphs (i), (k), (l), ( $m),(n),(0),(p)$ and $(r)$ of the Letter of Second-Stage Bid.

6.5 If the Contactor is debarred or temporarily suspended by ADB, it shall inform the Employer of such debarment or suspension, and that the endorsement of ADB's Office of Anticorruption and Integrity is required for any variations, extensions or modifications to the Contract.

\section{Scope of Facilities}

7.3 The Contractor agrees to supply spare parts for a period of years: [insert number of years as appropriate]

\section{NOTE}

Where appropriate, use the following additional provision to SCC 7.3.

The Contractor shall carry sufficient inventories to ensure an ex-stock supply of consumable spares for the Plant. Other spare parts and components shall be supplied as promptly as possible, but at the most within 6 months of placing the order and opening the letter of credit. In addition, in the event of termination of the production of spare parts, advance notification will be made to the Employer of the pending termination, with sufficient time to permit the Employer to procure the needed requirement. Following such termination, the Contractor will furnish to the extent possible and at no cost to the Employer the blueprints, drawings, and specifications of the spare parts, if requested. 


\section{Time for Commencement and Completion}

8.1 The Contractor shall commence work on the Facilities within [insertnumber of days as appropriate] days from the Effective Date for determining Time for Completion as specified in the Contract Agreement provided that access to and possession of the Site or any part thereof have been given under subclause 10.2, and shall then proceed with the work on the Facilities with due expedition and without delay.

8.2 The Time for Completion of the whole of the Facilities shall be [insert number of days as appropriate] days from the Effective Date as described in the Contract Agreement.

\section{NOTE}

Where appropriate, use the following additional provision to SCC 8.2.

Time for Completion for parts of the Facilities: [Each part of the facilities subject to a specific Time for Completion shall be listed and briefly described with its respective Time for Completion specified in days, in words and figures]

\section{Contractor's Responsibilities}

9.6 To add the following paragraph at the end of GCC 9.6:

"ADB's right to inspect the Site and/or the Contractor's accounts and records relating to the performance of the Contract stated in Subclause 6.1 (e) and 9.6 shall survive termination and/ or expiration of this Contract."

\subsection{Protection of the Environment}

At the end of the subclause in 9.8 Protection of the Environment, add the following paragraphs: "The Contractor shall comply with all applicable national, provincial, and local environmental laws and regulations. The Contractor shall also comply with all reasonable requests of the national and local authorities responsible for enforcing environmental controls.

Within 28 days of the Commencement Date the Contractor shall submit a detailed Site Specific Environmental Management Plan (SSEMP), based on the Environmental Health and Safety Management Plan submitted in the technical proposal, for the Project Manager's no objection showing how the Contractor intends to comply with environmental laws and regulations and other specific requirements prescribed in the Contract, addressing all the monitoring and mitigation measures set forth in the Environmental Impact Assessment ("EIA") and the Environmental Management Plan ("EMP") of the project attached in Section 6- Employer's Requirements. Work shall not commence on the Site until the no objection of SSEMP has been obtained from the Project Manager and is being implemented.

The Contractor shall (a) establish an operational system for managing environmental impacts, (b) comply with the approved SSEMP and any corrective or preventative actions set out in safeguards monitoring reports that the Employer will prepare from time to time to monitor the implementation of the project EMP through the SSEMP, (c) allocate the budget required to ensure that such measures, requirements and actions are carried out, (d) submit semi-annual reports on the compliance of such measures to the Employer.

Where unanticipated environmental risks or impacts become apparent during the Contract, the Contractor is required to update the SSEMP to outline the potential impacts to site works and associated mitigation measures for the Project Manager's approval." 


\section{Employer's Responsibilities}

10.2 "There shall be no work nor construction activities at the Site or any part thereof (as the case may be) unless the Employer has granted access to the Site or part thereof (as the case may be) in accordance with this Subclause 10.2."

\section{Contract Price}

\section{NOTE}

This provision to be inserted only if contract price is subject to adjustment. Price adjustment is used where the contract period is of long duration (generally exceeds 18 months). It is normal procedure that prices payable to the contractor shall be subject to price adjustment during the performance of the contract.

11.2 The Contract Price shall be adjusted in accordance with the provisions of Appendix 2 (Price Adjustment) to the Contract Agreement.

\section{Securities}

13.3.1 The amount of performance security, as a percentage of the Contract Price for the Facility or for the part of the Facility for which a separate Time for Completion is provided, shall be: [insert amount, which should not exceed 10\% of the contract price].

13.3.2 The performance security shall be in the form of the [insert "in the form of a bank guarantee] as per form included in Section 9 (Contract Forms).

\section{NOTE}

The following provision shall be used, if appropriate, for the type of facilities.

13.3.3 The performance security shall not be reduced on the date of the Operational Acceptance.

or

\section{NOTE}

The following provision should be used when the facilities have warranty obligations beyond the defect liability period, pursuant to the provisions in the SCC under GCC Clause 12.

13.3.4 The performance security shall be reduced to $10 \%$ of the value of the component covered by the extended defect liability to cover the Contractor's extended defect liability in accordance with the provision in the SCC, pursuant to GCC Subclause 27.10. 


\section{Subcontracting}

\section{NOTE}

When appropriate, use the following additional provision to SCC 19.6.

19.6 The Contractor shall not subcontract (i) works with a total accumulated value greater than the specified percentage of the Contract Price, or (ii) any part of the Works for which subcontracting is not permitted as specified below;

(i) Maximum allowable accumulated value of work subcontracted (as a percentage of the Contract Price): $\%$

(ii) Parts of the Works for which subcontracting is not permitted:

\section{Design and Engineering}

\subsection{Approval/Review of Technical Documents by Project Manager}

\section{NOTE}

When 14-day period for the approval may be unrealistic, use the following provision.

20.3.2 Within 21 days after receipt by the Project Manager of any document requiring the Project Manager's approval in accordance with GCC Subclause 20.3.1, the Project Manager shall either return one copy thereof to the Contractor with its approval endorsed thereon or shall notify the Contractor in writing of its disapproval thereof and the reasons therefor and the modifications that the Project Manager proposes.

If the Project Manager fails to take such action within the said $\mathbf{2 1}$ days, then the said document shall be deemed to have been approved by the Project Manager.

\section{Installation}

\subsection{Labor}

\subsubsection{Working Hours}

(a) Normal working hours are: [indicate working hours]

\subsubsection{Health and Safety}

(a) The Contractor shall throughout the contract (including the Defect Liability Period),

(i) conduct Information, Education, and Consultation Communication (IEC) campaigns, at least every other month, addressed to all the Site staff and labor (including all the Contractor's employees, all Subcontractor's and Employer's and Project Manager's employees, and all truck drivers and crew making deliveries to Site for construction activities) and to the immediate local communities, concerning the risks, dangers, and impact, and appropriate avoidance behavior with respect to Sexually Transmitted Diseases (STD) - or Sexually Transmitted Infections (STI) in general and HIV/AIDS in particular; 
(ii) provide male or female condoms for all Site staff and labor as appropriate; and

(iii) provide for STI and HIV/AIDS screening, diagnosis, counseling, and referral to a dedicated national STI and HIV/AIDS program, (unless otherwise agreed) of all Site staff and labor.

The Contractor shall include in the program to be submitted for the execution of the Facilities under Subclause 18.2 an alleviation program for Site staff and labor and their families in respect of STI and STD including HIV/AIDS. The STI, STD, and HIV/AIDS alleviation program shall indicate when, how, and at what cost the Contractor plans to satisfy the requirements of this Subclause and the related specification. For each component, the program shall detail the resources to be provided or utilized and any related subcontracting proposed. The program shall also include provision of a detailed cost estimate with supporting documentation. Payment to the Contractor for the preparation and implementation this program shall not exceed the amount dedicated for this purpose.

After the existing paragraph in GCC 22.2.7 (a), add the following:

"The Contractor is responsible for establishment of preventive and emergency preparedness and response measures to avoid, and where avoidance is not possible, to minimize, adverse impacts and risks of the construction site work to the health and safety of local communities.

Within 28 days of the Effective Date the Contractor shall submit a detailed Site Specific Health and Safety Management Plan (SSHSMP), based on the Environmental Health and Safety Management Plan submitted in the technical proposal, for the Project Manager's no objection showing how he/she intends to comply with the local Health and Safety laws and regulations and other specific requirements prescribed in the Contract, taking into account the Supplementary Information in Section 6- Employer's Requirements. Work shall not commence on the Site until the confirmation of no objection of the SSHSMP has been obtained from the Project Manager and is being implemented.

Where unanticipated health and safety hazards or risks become apparent during the Contract, the Contractor is required to update the SSHSMP to outline the potential impacts to site works and associated mitigation measures for the Project Manager's no objection.

The Contractor shall comply with the approved SSHSMP and any corrective or preventative actions set out in safeguards monitoring reports that the Employer will prepare from time to time to monitor the implementation of the project EMP through the SSHSMP.

In particular, the Contractor is required to provide all personnel on site including Employer's Personnel and visitors with personal protective equipment, including protection for feet (safety boots), head, eyes, ears (safety helmets) and hands, etc. , in accordance with the Contractor's SSHSMP. The Contractor should ensure that his Subcontractors comply with the SSHSMP and provide all such necessary equipment to their personnel.

The Contractor shall bear the costs to ensure that such measures, requirements and actions are carried out.

The Contractor shall submit semi-annual reports on the compliance of such measures to the Employer."

Add after the existing paragraph in GCC 22.2.7 (c) the following: 
"In the event of a significant injury involving medical treatment or hospitalization and fatal accident the Contractor shall notify the Project Manager immediately by verbal communication and submit a formal report as soon as practicable after its occurrence. For all accidents, whether fatal or not, the Contractor shall also notify the appropriate local authorities in accordance with the Laws of the Country."

\subsubsection{Funeral Arrangements}

Funeral arrangements: [describe funeral arrangements]

\subsubsection{Respectful Work Environment}

The Contractor shall ensure that its employees and Subcontractors observe the highest ethical standards and refrain from any form of bullying, discrimination, misconduct, and harassment, including sexual harassment and shall, at all times, behave in a manner that creates an environment free of unethical behavior, bullying, misconduct and harassment, including sexual harassment. The Contractor shall take appropriate action against any employees or Subcontractors, including suspension or termination of employment or subcontract, if any form of unethical or inappropriate behavior is identified.

The Contractor shall conduct training programs for its employees and Subcontractors to raise awareness on and prevent any form of bullying, discrimination, misconduct, and harassment including sexual harassment, and to promote a respectful work environment. The Contractor shall keep an up to date record of its employees and Subcontractors who have attended and completed such training programs and provide such records to the Employer or the Engineer at their first written request.

\section{Commissioning and Operational Acceptance}

25.2.2 The Guarantee Test of the Facilities shall be successfully completed within [days, written in words and figures] from the date of Completion.

\section{NOTE}

Parts and separate times for the respective guarantee test shall be specified where applicable.

\section{Completion Time Guarantee}

26.2 Applicable rate for liquidated damages: [insert percentage figure. The applicable rate shall not exceed $0.5 \%$ perweek]

Maximum deduction for liquidated damages: [insert a percentage. The maximum percentage shall not exceed $10 \%$ of the contract price]

26.3 Applicable (amount or rate) for the bonus for early Completion: [insert appropriate amount or rate as a percentage of the contract price, or part thereof, in words and figures, per week of early completion of the facilities or part thereof, in accordance with the Time for Completion specified in the SCC, with a corresponding reference in GCC 8]

Maximum bonus: [insert the maximum amount, which should be related to the benefit the employer will gain in operating the facilities, or part thereof, earlier than anticipated] 


\section{NOTE}

For a contract without a bonus, the following provision should be used.

No bonus will be given for earlier Completion of the Facilities or part thereof.

\section{Defect Liability}

\section{NOTES}

The Employer should not extend the defect liability period beyond the period prescribed in GCC Subclause 27.2, except where it is commercial practice for critical components in the type of facility, and in which case the relevant period shall be specified in the SCC under GCC Subclause 27.10.

The provision below should be used only when an extended defect liability is requested.

27.10 The critical components covered under the extended defect liability are [the components should either be mentioned herein or a reference should be made to the related paragraph in Section 6 (Employer's Requirements)], and the period shall be [number of years, which shall not exceed 5 years].

\section{Limitation of Liability}

\section{NOTE}

Use the following provision only if it is intended to have a limitation of liability that is a multiple of the contract price.

30.1 (b) The multiplier of the Contract Price is: [insert multiplier]

\section{Termination}

\subsection{Termination for Employer's Convenience}

42.1.3 (f) a reasonable amount of profit for the parts of the Works not executed by the Contractor as at the date of termination.

\section{Disputes and Arbitration}

45.1 The Dispute Board shall be appointed within [28 days] after the Effective Date.

The Dispute Board shall be [insert either "one sole member" or "a Dispute Board of three members"]

List of potential Dispute Board members is: [insert "list names of potential sole members only when the Dispute Board is to comprise one sole member. Insert: "None" if no potential sole members are to be included]. 
45.2 Appointment (if not agreed) to be made by: [insert appointing entity or official. The appointing entity or official must not, in any way, be related or connected to the Employer (project executing agency and/or implementing agency)].

\section{NOTES}

For contracts entered into with foreign contractors, international commercial arbitration may have practical advantages over other dispute settlement methods. ADB should neither be named as arbitrator nor be asked to name an arbitrator. Among the rules to govern the arbitration proceedings, the Employer may wish to consider the United Nations Commission on International Trade Law (UNCITRAL) Arbitration Rules of 1976, the Rules of Arbitration of the International Chamber of Commerce (ICC), the Rules of the London Court of International Arbitration, or the Rules of Arbitration Institute of the Stockholm Chamber of Commerce.

For contracts entered into with a contractor who is a national of the Employer's country, the contract may provide for adjudication/arbitration in accordance with the law of the employer's country.

Clause 45.5(a) shall be retained in the case of a contract with a foreign contractor and clause 45.5(b) shall be retained in the case of a contract with a national of the Employer's country.

45.3 This sentence shall be added as last paragraph in GCC Subclause 45.3:

If the decision of the Dispute Board requires a payment by one Party to the other Party, the Dispute Board may require the payee to provide an appropriate security in respect of such payment.

45.5 Rules of procedure for arbitration proceedings:

(a) Contracts with foreign contractors:

International arbitration shall be conducted in accordance with the rules of [insert here the preferred international arbitration rules]. If no rules have been specified, then the Rules of the Singapore International Arbitration Centre (SIAC) shall apply.

Arbitration shall be administered by [insert institution here]. If no institution has been specified, then SIAC shall be the institution to administer the arbitration.

The place of arbitration shall be the place of the institution administering the arbitration.

(b) Contracts with contractors being nationals of the Employer's country: [Any dispute between the employer and a contractor who is a national of the Employer's country arising in connection with the present contract shall be referred to arbitration in accordance with the laws of the Employer's country.]

45.6 GCC Subclause 45.6 shall be replaced with the following sentence:

In the event that a Party fails to comply with a Dispute Board decision which has become ether binding or final and binding, then the other Party may, without prejudice to any other rights it may have, refer the failure itself to arbitration under Subclause 45.5 [Arbitration] for summary or other expedited relief, as may be appropriate. Subclause 45.3 [Obtaining Dispute Board's Decision] and Subclause 45.4 [Amicable Settlement] shall not apply to this reference. 


\section{Eligibility}

46.1 The Contractor shall have the nationality of an ADB member. The Contractor shall be deemed to have the nationality of a country if the Contractor is a citizen or is constituted, incorporated, or registered, and operates in conformity with the provisions of the laws of that country. This criterion shall also apply to the determination of the nationality of proposed Subcontractors or Suppliers for any part of the Contract including related services.

46.2 The materials, equipment, and services to be supplied under the Contract shall have their origin in eligible source countries and all expenditures under the Contract will be limited to such materials, equipment, and services. At the Employer's request, the Contractor may be required to provide evidence of the origin of materials, equipment, and services.

46.3 For purposes of SCC 46.2, "origin" means the place where the materials and equipment are mined, grown, produced, or manufactured, and from which the services are provided. Materials and equipment are produced when, through manufacturing, processing, or substantial or major assembling of components, a commercially recognized product results that differs substantially in its basic characteristics or in purpose or utility from its components. 


\section{Section 9: Contract Forms}

This Section contains the Letter of Acceptance, the Contract Agreement, and Appendixes to the Contract Agreement, which, once completed, will form part of the Contract. When required, the Performance Security and Advance Payment Security, substantially in the forms provided, shall be submitted by the successful Bidder after contract award.

\section{Table of Forms}

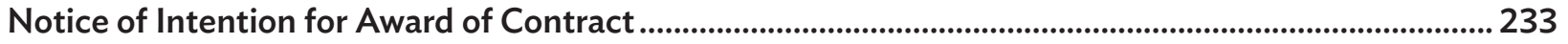

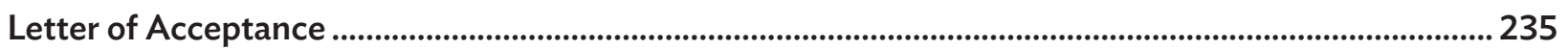

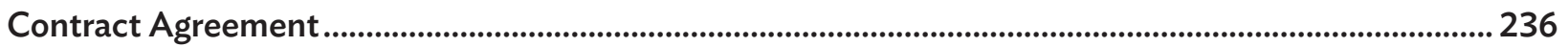

Appendix 1: Terms and Procedures of Payment ............................................................................................ 240

Appendix 2: Price Adjustment......................................................................................................................... 243

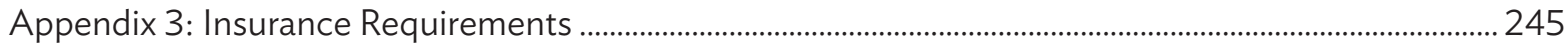

Appendix 4: Time Schedule................................................................................................................................... 248

Appendix 5: List of Major Items of Plant and Services and List of Approved Subcontractors ................ 249

Appendix 6: Scope of Works and Supply by the Employer ................................................................................ 250

Appendix 7: List of Documents for Approval or Review ................................................................................. 251

Appendix 8: Functional Guarantees...................................................................................................................... 252

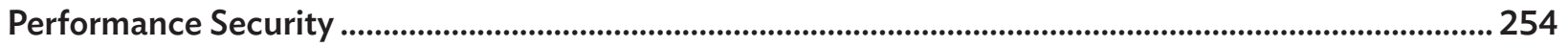

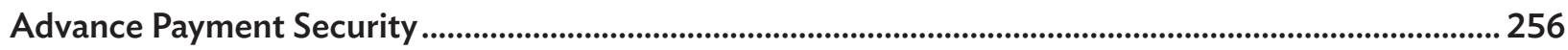




\title{
Notice of Intention for Award of Contract
}

\author{
[on letterhead of Employer]
}

[date of notification]

To: $\quad$ [name of Bidder]

Attention: [insert name of the Bidder's authorized representative]

Address: [insert address of the Bidder's authorized representative]

Telephone/Fax numbers: [insert telephone/fax numbers of the Bidder's authorized representative]

E-mail Address: [insert e-mail address of the Bidder's authorized representative]

This is to notify you of our intention to award the contract [insert name of the contract and identification number, as given in the Bid Data Sheet]. You have [insert number of days as specified in ITB 40.1 (or ITB 52.1 under two-stage bidding) of the BDS] days from the date of this notification to (i) request for a debriefing in relation to the evaluation of your Bid; and/or (ii) submit a bidding-related complaint in relation to the intention for award of contract, in accordance with the procedures specified in ITB 45.1 [or ITB 57.1 under two-stage bidding].

The summary of the evaluation are as follows:

1. List of Bidders [insert names of all Bidders that submitted a bid together with the corresponding bid price at opening and evaluated bid price (if applicable)]

\begin{tabular}{|l|l|l|}
\hline Name of Bidder & Bid Price as Read Out at Opening & Evaluated Bid Price \\
\hline & & \\
\hline & & \\
\hline & & \\
\hline & & \\
\hline
\end{tabular}

2. Reason(s) Why Your Bid Was Unsuccessful

[provide reasons separately to each unsuccessful Bidder why its bid was unsuccessful]

\section{The Successful Bidder}

\begin{tabular}{|l|l|}
\hline Name of Bidder: & \\
\hline Address: & \\
\hline Accepted Contract Amount: & \\
\hline Duration of Contract: & \\
\hline Scope of the Contract Awarded: & \\
\hline Amount Performance Security Required: & \\
\hline
\end{tabular}


Authorized Signature:

Name and Title of Signatory:

Name of Agency:

\section{NOTE}

The Employer should send this notification to each Bidder that submitted a bid simultaneously. Notice of Intention for Award of Contract shall only be included if standstill provision is applicable in accordance with ITB 40.1 Single-Stage Bidding or ITB 52.1 Two-Stage Bidding. Also, for bidding-related complaint, follow the procedure in accordance with ITB 45.1 Single-Stage Bidding or ITB 57.1 Two-Stage Bidding. 


\section{Letter of Acceptance}

To: [Name and address of the contractor]

Subject: Contract No. [please specify]

This is to notify you that your Bid dated [date] for execution of the [name of the contract and identification number, as given in the Bid Data Sheet] for the Contract Price in the aggregate of [amounts in words and figures] [name of currency], as corrected and modified in accordance with the Instructions to Bidders is hereby accepted by our Agency.

You are requested to furnish the Performance Security within 28 days in accordance with the Conditions of Contract and any additional security required as a result of the evaluation of your bid, using for that purpose one of the Performance Security Forms included in Section 9 (Contract Forms) of the Bidding Document.

Authorized Signature:

Name and Title of Signatory:

Name of Agency:

Attachment: Contract Agreement

\section{NOTE}

The Notification of Award will be the basis for formation of the contract as described in ITB 42 Single-Stage Bidding or ITB 54 Two-Stage Bidding. This standard form should be filled out and sent to the successful Bidder only after evaluation of bids has been completed, subject to any review by $A D B$ required under the Financing Agreement. 


\section{Contract Agreement}

THIS AGREEMENT made on the [insert number] day of [insert month], [insert year],

\section{BETWEEN}

(1) [name of the Employer], a corporation incorporated under the laws of [country of the Employer] and having its principal place of business at [address of the Employer] (hereinafter called "the Employer"), and (2) [name of the contractor], a corporation incorporated under the laws of [country of the contractor] and having its principal place of business at [address of the contractor] (hereinafter called "the Contractor").

WHEREAS the Employer desires to engage the Contractor to design, manufacture, test, deliver, install, complete, and commission certain Facilities, viz. [list of facilities] ("the Facilities") and the Contractor have agreed to such engagement upon and subject to the terms and conditions hereinafter appearing.

NOW IT IS HEREBY AGREED as follows:

\section{Article 1 \\ Contract \\ Documents}

\subsection{Contract Documents (Reference GCC Clause 2)}

The following documents shall constitute the Contract between the Employer and the Contractor, and each shall be read and construed as an integral part of the Contract:
(a) This Contract Agreement and the Appendixes hereto
(b) Letter of Bid and Price Schedules submitted by the Contractor
(c) Special Conditions of Contract
(d) List of Eligible Countries that was specified in Section 5 of the Bidding Document
(e) General Conditions of Contract
(f) Specifications
(g) Drawings
(h) Other completed Bidding Forms submitted with the Letter of Bid
(i) Any other documents forming part of the Employer's Requirements
(j) Any other documents shall be added here ${ }^{1}$

\subsection{Order of Precedence (Reference GCC Clause 2)}

In the event of any ambiguity or conflict between the Contract Documents listed above, the order of precedence shall be the order in which the Contract Documents are listed in Article 1.1 (Contract Documents) above.

\subsection{Definitions (Reference GCC Clause 1)}

Capitalized words and phrases used herein shall have the same meanings as are ascribed to them in the General Conditions.

1 Tables of Adjustment Data may be added if the contract provides for price adjustment (see GCC 11). 
Article 2

Contract Price and

Terms of Payment

Article 3

Effective Date
2.1 Contract Price (Reference GCC Clause 11)

The Employer hereby agrees to pay to the Contractor the Contract Price in consideration of the performance by the Contractor of its obligations hereunder. The Contract Price shall be the aggregate of [amounts offoreigncurrency in words], [amounts in figures] as specified in Price Schedule No. 5 (Grand Summary), [amounts of local currency in words], [amounts in figures], or such other sums as may be determined in accordance with the terms and conditions of the Contract.

\subsection{Terms of Payment (Reference GCC Clause 12)}

The terms and procedures of payment according to which the Employer will reimburse the Contractor are given in the Appendix (Terms and Procedures of Payment) hereto.

The Employer shall instruct its bank to issue an irrevocable confirmed documentary credit made available to the Contractor in a bank in the country of the Contractor. The credit shall be for an amount of [amount equal to the total named in Schedule 1 less the advance payment to be made for plant and mandatory spare parts supplied from abroad]; and shall be subject to the Uniform Customs and Practice for Documentary Credits 1993 Revision, ICC Publication No. 500. ${ }^{2}$

In the event that the amount payable under Schedule No. 1 is adjusted in accordance with GCC 11.2 or with any of the other terms of the Contract, the Employer shall arrange for the documentary credit to be amended accordingly.

\section{NOTE}

The Employer may want to insert a similar provision for the payment of the items listed in Schedule No. 2.

\subsection{Effective Date (Reference GCC Clause 1)}

The Effective Date upon which the period until the Time for Completion of the Facilities shall be counted from is the date when all of the following conditions have been fulfilled:

(a) This Contract Agreement has been duly executed for and on behalf of the Employer and the Contractor.

(b) The Contractor has submitted to the Employer the performance security and the advance payment guarantee.

(c) The Employer has paid the Contractor the advance payment.

(d) The Contractor has been advised that the documentary credit referred to in Article 2.2 above has been issued in its favor.

Each party shall use its best efforts to fulfill the above conditions for which it is responsible as soon as practicable.

2 Or Uniform Customs and Practice for Documentary Credits 2007 Revision, ICC Publication No. 600 (or the latest version). 
3.2 If the conditions listed under 3.1 are not fulfilled within 2 months from the date of this Contract notification because of reasons not attributable to the Contractor, the parties shall discuss and agree on an equitable adjustment to the Contract Price and the Time for Completion and/or other relevant conditions of the Contract.

Article 4

Communications

Article 5

Appendixes
4.1 The address of the Employer for notice purposes, pursuant to GCC 4.1 is [Employer's address].

4.2 The address of the Contractor for notice purposes, pursuant to GCC 4.1 is [Contractor's address].

5.1 The Appendixes listed in the attached List of Appendixes shall be deemed to form an integral part of this Contract Agreement.

5.2 Reference in the Contract to any Appendix shall mean the Appendixes attached hereto, and the Contract shall be read and construed accordingly.

IN WITNESS WHEREOF the Employer and the Contractor have caused this Agreement to be duly executed by their duly authorized representatives the day and year first above written.

Signed by, for, and on behalf of the Employer

[Signature]

[Title]

in the presence of

[Signature]

[Title]

Signed by, for, and on behalf of the Contractor

[Signature]

[Title]

in the presence of

[Signature]

[Title] 


\section{APPENDIXES}

Appendix 1: Terms and Procedures of Payment

Appendix 2: Price Adjustment

Appendix 3: Insurance Requirements

Appendix 4: Time Schedule

Appendix 5: List of Major Items of Plant and Services and List of Approved Subcontractors

Appendix 6: Scope of Works and Supply by the Employer

Appendix 7: List of Documents for Approval or Review

Appendix 8: Functional Guarantees 


\section{Appendix 1: Terms and Procedures of Payment}

NOTE

The following Terms and Procedures of Payment are given as a guideline for supply and installation contracts. When the Employer wishes to introduce different terms of payment to the following, it shall first obtain the written approval of $A D B$ for the terms it intends to use. If additional price schedules are introduced, suitable terms of payment in respect of such additional schedules must be added.

In accordance with the provisions of GCC Clause 12 (Terms of Payment), the Employer shall pay the Contractor in the following manner and at the following times, based on the Price Breakdown given in the section on Price Schedules. Payments will be made in the currencies quoted by the Bidder unless otherwise agreed between the parties. Applications for payment in respect of part deliveries may be made by the Contractor as work proceeds.

\section{(A) Terms of Payment}

\section{Schedule No. 1 - Plant and Mandatory Spare Parts Supplied from Abroad}

In respect of plant and mandatory spare parts supplied from abroad, the following payments shall be made:

Ten percent (10\%) of the total CIP amount as an advance payment against receipt of invoice, and an irrevocable advance payment security for the equivalent amount made out in favor of the Employer. The advance payment security may be reduced in proportion to the value of the plant and mandatory spare parts delivered to the site, as evidenced by delivery documents.

Eighty percent (80\%) of the total or pro rata CIP or amount upon Incoterm "CIP," upon delivery to the site within 45 days after receipt of invoice.

Five percent (5\%) of the total or pro rata CIP or amount upon issue of the Completion Certificate, within 45 days after receipt of invoice.

Five percent (5\%) of the total or pro rata CIP or amount upon issue of the Operational Acceptance Certificate, within 45 days after receipt of invoice.

\section{Schedule No. 2 - Plant and Mandatory Spare Parts Supplied from Within the Employer's Country}

In respect of plant and mandatory spare parts supplied from within the Employer's country, the following payments shall be made:

Ten percent (10\%) of the total EXW amount as an advance payment against receipt of invoice, and an irrevocable advance payment security for the equivalent amount made out in favor of the Employer. The advance payment security may be reduced in proportion to the value of the plant and mandatory spare parts delivered to the site, as evidenced by delivery documents. 
Eighty percent (80\%) of the total or pro rata EXW amount upon Incoterm "Ex-Works," upon delivery to the site within 45 days after receipt of invoice.

Five percent (5\%) of the total or pro rata EXW amount upon issue of the Completion Certificate, within 45 days after receipt of invoice.

Five percent (5\%) of the total or pro rata EXW amount upon issue of the Operational Acceptance Certificate, within 45 days after receipt of invoice.

\section{Schedule No. 3 - Design Services}

In respect of design services for both the foreign currency and the local currency portions, the following payments shall be made:

Ten percent (10\%) of the total design services amount as an advance payment against receipt of invoice and an irrevocable advance payment security for the equivalent amount made out in favor of the Employer.

Ninety percent (90\%) of the total or pro rata design services amount upon acceptance of design by the Project Manager within 45 days after receipt of invoice.

\section{Schedule No. 4 - Installation and Other Services}

In respect of installation services for both the foreign and local currency portions, the following payments shall be made:

Ten percent (10\%) of the total installation and other services amount as an advance payment against receipt of invoice and an irrevocable advance payment security for the equivalent amount made out in favor of the Employer. The advance payment security may be reduced in proportion to the value of work performed by the Contractor as evidenced by the invoices for installation services.

Eighty percent (80\%) of the measured value of work performed by the Contractor, as identified in the said Program of Performance, during the preceding month, as evidenced by the Employer's authorization of the Contractor's application, will be made monthly within 45 days after receipt of invoice.

Five percent (5\%) of the total or pro rata value of installation services performed by the Contractor as evidenced by the Employer's authorization of the Contractor's monthly applications, upon issue of the Completion Certificate, within 45 days after receipt of invoice.

Five percent (5\%) of the total or pro rata value of installation services performed by the Contractor as evidenced by the Employer's authorization of the Contractor's monthly applications, upon issue of the Operational Acceptance Certificate, within 45 days after receipt of invoice.

In the event that the Employer fails to make any payment on its respective due date, the Employer shall pay to the Contractor interest on the amount of such delayed payment at the rate of [insert a figure that may be different for the foreign and local currency portions and a figure that reflects the cost of money in the respective currencies] percent (\%) per month for period of delay until payment has been made in full. 


\section{(B) Payment Procedures}

When applying for certification and making payments, the procedures shall be as follows:

\section{NOTE}

Insert appropriate procedures, usually letters of credit, including forms and certificates annexed as appropriate by the Employer in the bidding document. 


\section{Appendix 2: Price Adjustment}

\section{NOTES}

Where the contract period (excluding the defect liability period) exceeds 18 months, it is normal procedure that prices payable to the contractor shall be subject to adjustment during the performance of the contract to reflect changes occurring in the cost of labor and material components. In such cases, the bidding document shall include in this Appendix 2 a formula of the following general type, pursuant to GCC Subclause 11.2.

If there is no price adjustment or adjustment clause in the contract, the following provisions shall not be included. Instead, it shall be indicated under this Appendix 2 that the prices are to remain firm and fixed for the duration of the contract.

\section{Sample Price Adjustment Formula}

Prices payable to the Contractor, in accordance with the Contract, shall be subject to adjustment during performance of the Contract to reflect changes in the cost of labor and material components, in accordance with the following formula:

in which

$$
P_{1}=P_{0} \times\left(a+b \frac{L_{1}}{L_{0}}+c \frac{M_{1}}{M_{0}}\right)-P_{0}
$$

$P_{1} \quad=\quad$ adjustment amount payable to the Contractor

$P_{0} \quad=\quad$ Contract price (base price)

$a=$ percentage of fixed element in Contract price $\left(a=\ldots-\_\%\right)$

$b=$ percentage of labor component in Contract price $\left(b=\ldots-\_\%\right)$

$c=$ percentage of material and equipment component in Contract price $(c=\ldots$

$L_{0}, L_{1}=$ labor indexes applicable to the appropriate industry in the country of origin on the base date and the date for adjustment, respectively

$M_{0}, M_{1}=$ material and equipment indexes in the country of origin on the base date and the date for adjustment, respectively 


\section{Conditions Applicable to Price Adjustment}

The base date shall be the date 28 days prior to the deadline for submission of the Bid.

The date of adjustment shall be the midpoint of the period of manufacture or installation of the component or Plant.

The following conditions shall apply:

(a) No price increase will be allowed beyond the original delivery date unless covered by an extension of time awarded by the Employer under the terms of the Contract. No price increase will be allowed for periods of delay for which the Contractor is responsible. The Employer will, however, be entitled to any price decrease occurring during such periods of delay.

(b) If the currency in which the Contract price, $\mathrm{P}_{0}$, is expressed is different from the currency of the country of origin of the labor and/or materials indexes, a correction factor will be applied to avoid incorrect adjustments of the Contract price. The correction factor shall correspond to the ratio of exchange rates between the two currencies on the base date and the date for adjustment as defined above.

(c) No price adjustment shall be payable on the portion of the Contract price paid to the Contractor as an advance payment. 


\section{Appendix 3: Insurance Requirements}

\section{NOTE}

The Employer provides the following details prior to issuing the bidding document. In the event that the Employer provides insurance under the contract, appropriate details must also be given.

\section{(A) Types of Insurance to Be Taken Out by the Contractor}

In accordance with the provisions of GCC Clause 34, the Contractor shall at its expense take out and maintain in effect, or cause to be taken out and maintained in effect, during the performance of the Contract, the types of insurance set forth below in the sums and with the deductibles and other conditions specified. The identity of the insurers and the form of the policies shall be subject to the approval of the Employer, such approval not to be unreasonably withheld.

\section{(a) Cargo Insurance}

Covering loss or damage occurring, while in transit from the supplier's or manufacturer's works or stores until arrival at the Site, to the Facilities (including spare parts therefor) and to the construction equipment to be provided by the Contractor or its Subcontractors.

\begin{tabular}{|c|c|c|c|c|}
\hline $\begin{array}{c}\text { Amount } \\
\text { [in currency(ies)] }\end{array}$ & $\begin{array}{c}\text { Deductible limits } \\
\text { [in currency(ies)] }\end{array}$ & $\begin{array}{c}\text { Parties insured } \\
\text { [names] }\end{array}$ & $\begin{array}{c}\text { From } \\
\text { [place] }\end{array}$ & $\begin{array}{c}\text { To } \\
\text { [place] }\end{array}$ \\
\hline & & & & \\
\hline & & & & \\
\hline
\end{tabular}

\section{(b) Installation All Risks Insurance}

Covering physical loss or damage to the Facilities at the Site, occurring prior to completion of the Facilities, with an extended maintenance coverage for the Contractor's liability in respect of any loss or damage occurring during the defect liability period while the Contractor is on the Site for the purpose of performing its obligations during the defect liability period.

\begin{tabular}{|c|c|c|c|c|}
\hline $\begin{array}{c}\text { Amount } \\
\text { [in currency(ies)] }\end{array}$ & $\begin{array}{c}\text { Deductible limits } \\
\text { [in currency(ies)] }\end{array}$ & $\begin{array}{c}\text { Parties insured } \\
\text { [names] }\end{array}$ & $\begin{array}{c}\text { From } \\
\text { [place] }\end{array}$ & $\begin{array}{c}\text { To } \\
\text { [place] }\end{array}$ \\
\hline & & & & \\
\hline & & & & \\
\hline
\end{tabular}




\section{(c) Third Party Liability Insurance}

Covering bodily injury or death suffered by third parties (including the Employer's personnel) and loss of or damage to property (including the Employer's property and any parts of the Facilities that have been accepted by the Employer), occurring in connection with the supply and installation of the Facilities.

\begin{tabular}{|c|c|c|c|c|}
\hline $\begin{array}{c}\text { Amount } \\
\text { [in currency(ies)] }\end{array}$ & $\begin{array}{c}\text { Deductible limits } \\
\text { [in currency(ies)] }\end{array}$ & $\begin{array}{c}\text { Parties insured } \\
\text { [names] }\end{array}$ & $\begin{array}{c}\text { From } \\
\text { [place] }\end{array}$ & $\begin{array}{c}\text { To } \\
\text { [place] }\end{array}$ \\
\hline & & & & \\
\hline & & & & \\
\hline
\end{tabular}

\section{(d) Automobile Liability Insurance}

Covering use of all vehicles used by the Contractor or its Subcontractors (whether owned by them or not) in connection with the supply and installation of the Facilities. Comprehensive insurance in accordance with statutory requirements.

\section{(e) Workers' Compensation}

In accordance with the statutory requirements applicable in any country where the Facilities or any part thereof is executed.

\section{(f) Employer's Liability}

In accordance with the statutory requirements applicable in any country where the Facilities or any part thereof is executed.

\section{(g) Other Insurance}

The Contractor is also required to take out and maintain at its own cost the following types of insurance:

\section{Details:}

\begin{tabular}{|c|c|c|c|c|}
$\begin{array}{c}\text { Amount } \\
\text { [in currency(ies)] }\end{array}$ & $\begin{array}{c}\text { Deductible limits } \\
\text { [in currency(ies)] }\end{array}$ & $\begin{array}{c}\text { Parties insured } \\
\text { [names] }\end{array}$ & $\begin{array}{c}\text { From } \\
\text { [place] }\end{array}$ & $\begin{array}{c}\text { To } \\
\text { [place] }\end{array}$ \\
\hline & & & & \\
\hline & & & & \\
\hline
\end{tabular}

The Employer shall be named as co-insured under all insurance policies taken out by the Contractor pursuant to GCC Subclause 34.1, except for the Third Party Liability, Workers' Compensation, and Employer's Liability Insurance, and the Contractor's Subcontractors shall be named as co-insureds under all insurance policies taken out by the Contractor pursuant to GCC Subclause 34.1, except for the Cargo, Workers' Compensation, and Employer's Liability Insurance. All insurer's rights of subrogation against such co-insureds for losses or claims arising out of the performance of the Contract shall be waived under such policies. 
(B) Types of Insurance to Be Taken Out by the Employer

\section{NOTE}

If the Employer is proposing to take out any or all of the above insurance policies itself, or any other insurance policies in respect of the facilities, either in its own name or in the joint names of itself and the contractor, it shall give details below prior to issuing the bidding document. Under the terms of the contract, the contractor and the contractor's Subcontractors shall be named as co-insured under all such policies.

The Employer shall at its expense take out and maintain in effect during the performance of the Contract the following insurance policies.

\section{Details:}

\begin{tabular}{|l|c|c|c|c|}
$\begin{array}{c}\text { Amount } \\
\text { [in currency(ies)] }\end{array}$ & $\begin{array}{c}\text { Deductible limits } \\
\text { [in currency(ies)] }\end{array}$ & $\begin{array}{c}\text { Parties insured } \\
\text { [names] }\end{array}$ & $\begin{array}{c}\text { From } \\
\text { [place] }\end{array}$ & $\begin{array}{c}\text { To } \\
\text { [place] }\end{array}$ \\
\hline & & & & \\
\hline & & & & \\
\hline
\end{tabular}




\section{Appendix 4: Time Schedule}

\section{NOTES}

The Employer should normally provide a time schedule to be followed by the contractor during the performance of the contract. This schedule should be provided with the bidding document under this appendix. All completion times indicated must be in accordance with the information regarding time(s) for completion given in Section 8: Special Conditions of Contract.

Except under exceptional circumstances, the time schedule should indicate periods of time (e.g., weeks or months) and not specify calendar dates. All periods should be shown from the effective date of the contract.

Should it become necessary to amend the time schedule to reflect agreements made with the selected Bidder prior to award of contract, the amended time schedule shall replace the original time schedule before the contract agreement is signed.

If the bidding document does not contain a time schedule, the Bidder shall be required to submit with its bid a detailed program, normally in the form of a bar chart, showing how and the order in which it intends to perform the contract and showing the key events requiring action or decision by the Employer. In preparing this program, the Bidder shall adhere to the time(s) for completion given in the bid data sheet or give its reasons for not adhering thereto. The time schedule submitted by the selected Bidder and amended as necessary prior to award of contract shall be included as appendix to the contract agreement before the contract is signed. 


\section{Appendix 5: List of Major Items of Plant and Services and List of Approved Subcontractors}

\section{NOTE}

Prior to issuing the bidding document, the Employer has established a list of major items of plant and services for which approval of the Employer is required. Prior to award of contract, the details of approved Subcontractors, including manufacturers shall be completed, indicating those Subcontractors proposed by the Bidder in the corresponding attachment to its bid that are approved by the Employer for engagement by the contractor during the performance of the contract.

A list of major items of plant and services is provided below.

The following Subcontractors and Manufacturers are approved for carrying out the item of the facilities indicated. Where more than one Subcontractor is listed, the Contractor is free to choose between them, but it must notify the Employer of its choice in good time prior to appointing any selected Subcontractor. In accordance with GCC Subclause 19.1, the Contractor is free to submit proposals for Subcontractors for additional items from time to time. No Subcontracts shall be placed with any such Subcontractors for additional items until the Subcontractors have been approved in writing by the Employer and their names have been added to this list of Approved Subcontractors.

\begin{tabular}{|l|c|c|}
\hline Major Items of Plant and Services & $\begin{array}{c}\text { Approved Subcontractors and } \\
\text { Manufacturers }\end{array}$ & Nationality \\
\hline & & \\
\hline & & \\
\hline
\end{tabular}




\section{Appendix 6: Scope of Works and Supply by the Employer}

\section{NOTES}

Prior to issuing the bidding document, the Employer shall indicate in this appendix, details of all personnel and facilities it will provide for use by the contractor, and indicate, where applicable, the charges it will make in respect of their use.

The Employer shall also identify any part(s) of the facilities it intends to carry out itself (or by other contractors), and any plant, equipment, or materials that it proposes to purchase itself and supply to the contractor for incorporation in the facilities, indicating, where applicable, the charges it will make in respect thereof.

The following personnel, facilities, works, and supplies will be provided or supplied by the Employer, and the provisions of GCC Clauses 10, 21, and 24 shall apply as appropriate.

All personnel, facilities, works, and supplies will be provided by the Employer in good time so as not to delay the performance of the Contractor, in accordance with the approved Time Schedule and Program of Performance pursuant to GCC Subclause 18.2.

Unless otherwise indicated, all personnel, facilities, works, and supplies will be provided free of charge to the Contractor.

\begin{tabular}{|l|l|}
\hline Personnel & Charge to Contractor (if any) \\
\hline & \\
\hline & \\
\hline
\end{tabular}

\begin{tabular}{|c|c|}
\hline Facilities & Charge to Contractor (if any) \\
\hline & \\
\hline & \\
\hline
\end{tabular}

\begin{tabular}{|c|c|}
\hline Works & Charge to Contractor (if any) \\
\hline & \\
\hline & \\
\hline
\end{tabular}




\section{Appendix 7: List of Documents for Approval or Review}

Pursuant to GCC Subclause 20.3.1, the Contractor shall prepare, or cause its Subcontractor to prepare, and present to the Project Manager in accordance with the requirements of GCC Subclause 18.2 (Program of Performance), the following documents for

\section{(A) Approval}

1.

2.

3.

(B) Review

1.

2.

3. 


\section{Appendix 8: Functional Guarantees}

\section{General}

This Appendix sets out

(a) the functional guarantees referred to in GCC Clause 28 (Functional Guarantees);

(b) the preconditions to the validity of the functional guarantees, either in production and/or consumption, set forth below;

(c) the minimum level of the functional guarantees;

(d) the formula for calculating liquidated damages for failure to attain the functional guarantees.

\section{Preconditions}

The Contractor gives the functional guarantees (specified herein) for the facilities, subject to the following preconditions being fully satisfied:

[List any condition for carrying out the guarantee test referred to in GCC Subclause 25.2]

\section{Functional Guarantees}

Subject to compliance with the foregoing preconditions, the Contractor guarantees as follows:

\subsection{Production Capacity}

[List here the production capacity that the contractor is to guarantee, making sure to use, as functional guarantees, the figures offered by the contractor in its bid]

and/or

\subsection{Raw Materials and Utilities Consumption}

[List here the guaranteed items of consumption per unit of production (e.g., kilogram, tons, kilocalories, kilowatthour, etc.) that the contractor is to guarantee, making sure to use, as functional guarantees, the figures offered by the contractor in its bid]

\section{Failure in Guarantees and Liquidated Damages}

\subsection{Failure to Attain Guaranteed Production Capacity}

If the production capacity of the facilities attained in the guarantee test, pursuant to GCC Subclause 25.2, is less than the guaranteed figure specified in para. 3.1 above, but the actual production capacity attained in the guarantee test is not less than the minimum level specified 
in para. 4.3 below, and the Contractor elects to pay liquidated damages to the Employer in lieu of making changes, modifications, and/or additions to the Facilities, pursuant to GCC Subclause 28.3, then the Contractor shall pay liquidated damages at the rate of [amount in the contract currency] for every complete $1 \%$ of the deficiency in the production capacity of the Facilities, or at a proportionately reduced rate for any deficiency, or part thereof, of less than a complete $1 \%$.

\subsection{Raw Materials and Utilities Consumption in Excess of Guaranteed Level}

[To be specified in the appropriate wording for the type of facilities if there is a consumption guarantee]

If the actual measured figure of specified raw materials and utilities consumed per unit (or their average total cost of consumption) exceeds the guaranteed figure specified in para. 3.2 above (or their specified average total cost of consumption), but the actual consumption attained in the guarantee test, pursuant to GCC Subclause 25.2, is not more than the maximum level specified in para. 4.3 below, and the Contractor elects to pay liquidated damages to the Employer in lieu of making changes, modifications, and/or additions to the Facilities pursuant to GCC Subclause 28.3, then the Contractor shall pay liquidated damages at the rate of [amount in the contract currency] for every complete $1 \%$ of the excess consumption of the Facilities, or part thereof, of less than a complete $1 \%$.

[The rate of liquidated damages specified in paras. 4.1 and 4.2 above shall be at least equivalent to the rate specified in Section 3 (Evaluation and Qualification Criteria) for the comparison of functional guarantees provided by the Bidders.]

\subsection{Minimum Levels}

Notwithstanding the provisions of this paragraph, if as a result of the guarantee test(s), the following minimum levels of performance guarantees (and consumption guarantees) are not attained by the Contractor, the Contractor shall at its own cost make good any deficiencies until the Facilities reach any of such minimum performance levels, pursuant to GCC Subclause 28.2:

(a) production capacity of the Facilities attained in the guarantee test: 95\% of the guaranteed production capacity,

and/or

(b) average total cost of consumption of all the raw materials and utilities of the Facilities: 105\% of the guaranteed figures.

\subsection{Limitation of Liability}

Subject to para. 4.3 above, the Contractor's aggregate liability to pay liquidated damages for failure to attain the functional guarantees shall not exceed . . . percent $(. . \%)$ of the Contract price [the percentage specified shall not exceed 10\%]. 


\section{Performance Security}

[Bank's name, and address of issuing branch or office $]^{1}$

Beneficiary:

[Name and address of the Employer]

Date:

Performance Guarantee No.:

We have been informed that [name of the Contractor] (hereinafter called "the Contractor") has entered into Contract No. [reference number of the Contract] dated [date] with you, for the execution of [name of Contract and brief description of plant and services] (hereinafter called "the Contract").

Furthermore, we understand that, according to the conditions of the Contract, a performance guarantee is required.

At the request of the Contractor, we [name of the bank] hereby irrevocably undertake to pay you any sum or sums not exceeding in total an amount of [name of the currency and amount in words] ${ }^{2}$ [amount in figures] such sum being payable in the types and proportions of currencies in which the Contract Price is payable, upon receipt by us of your first demand in writing accompanied by a written statement stating that the Contractor is in breach of its obligation(s) under the Contract, without your needing to prove or to show grounds for your demand or the sum specified therein.

This guarantee shall expire no later than the earlier of

(a) 18 months after our receipt of

(i) a copy of the Completion Certificate; or

(ii) a registered letter from the Contractor, attaching a copy of the notice to the project manager that the Facilities are ready for commissioning, and stating that 14 days have elapsed from receipt of such notice (or 7 days have elapsed if the notice was a repeated notice) and the project manager has failed to issue a Completion Certificate or inform the Contractor in writing of any defects or deficiencies; or

(iii) a registered letter from the Contractor stating that no Completion Certificate has been issued but the Employer is making use of the Facilities; or

(b) the $[$ date $]$ day of $[$ month], [year $] .^{3}$

All italicized text serves as a guide for preparing this demand guarantee and shall be deleted from the final document.

The guarantor shall insert an amount representing the percentage of the accepted contract amount specified in the contract and denominated either in the currency(ies) of the contract or in any freely convertible currency acceptable to the Employer.

3 Insert the expected expiration date of the Defect Liability Period. The employer should note that in the event of an extension of the time for completion of the contract, the Employer would need to request an extension of this guarantee from the guarantor. Such request must be in writing and must be made prior to the expiration date established in the guarantee. In preparing this guarantee, the Employer might consider adding the following text to the form, at the end of the penultimate paragraph: "The Guarantor agrees to a one-time extension of this guarantee for a period not to exceed [ 6 months][1 year], in response to the Employer's written request for such extension, such request to be presented to the Guarantor before the expiry of the guarantee." 
Consequently, any demand for payment under this guarantee must be received by us at this office on or before that date.

This guarantee is subject to the Uniform Rules for Demand Guarantees, (URDG) 2010 Revision, ICC Publication No. 758 except that the supporting statement under Article 15 (a) is hereby excluded. ${ }^{4}$

[Signature(s) and seal of bank (where appropriate)]

\section{Note to Bidder}

If the bank issuing performance security is located outside the Employer's country, it shall be counter-guaranteed or encashable by a bank in the Employer's country.

$4 \quad$ Or the employer may use Uniform Rules for Demand Guarantees, ICC Publication No. 458, except that subparagraph (ii) of Sub-article 20(a) is hereby excluded" as appropriate. 


\section{Advance Payment Security}

[Bank's name, and address of issuing branch or office $]^{1}$

Beneficiary: [Name and address of the Employer]

Date:

Advance Payment Guarantee No.:

We have been informed that [name of the Contractor] (hereinafter called "the Contractor") has entered into Contract No. [reference number of the Contract] dated [date] with you, for the execution of [name of Contract and brief description of plant and services] (hereinafter called "the Contract").

Furthermore, we understand that, according to the Conditions of the Contract, an advance payment in the sum [name of the currency and amount in words] ${ }^{2}$ [amount in figures] is to be made against an advance payment guarantee.

At the request of the Contractor, we [name of the bank] hereby irrevocably undertake to pay you any sum or sums not exceeding in total an amount of [name of the currency and amount in words] ${ }^{3}$ [amount in figures] upon receipt by us of your first demand in writing accompanied by a written statement stating that the Contractor is in breach of its obligation under the Contract because the Contractor:

(a) used the advance payment for purposes other than the costs of mobilization and cash flow support in respect of the Works; or

(b) has failed to repay the advance payment when it has become due and payable in accordance with the conditions of the Contract, specifying the amount payable by the Contractor.

It is a condition for any claim and payment under this guarantee to be made that the advance payment referred to above must have been received by the Contractor on its account number [Contractor's account number] at [name and address of the bank].

The maximum amount of this guarantee shall be progressively reduced by the amount of the advance payment repaid by the Contractor as indicated in copies of interim statements or payment certificates, which shall be presented to us. This guarantee shall expire, at the latest, upon our receipt of a copy of the interim payment certificate, indicating that $80 \%$ of the Contract Price has been certified for payment, or on the [date] day of [month], [year], ${ }^{4}$ whichever is earlier. Consequently, any demand for payment under this guarantee must be received by us at this office on or before that date.

All italicized text serves as a guide for preparing this demand guarantee and shall be deleted from the final document. The guarantor shall insert an amount representing the amount of the advance payment denominated either in the currency(ies) of the advance payment as specified in the contract, or in any freely convertible currency acceptable to the employer.

Footnote 2.

$4 \quad$ Insert the expected expiration date of the time for completion. The employer should note that in the event of an extension of the time for completion of the contract, the employer would need to request an extension of this guarantee from the guarantor. Such request must be in writing and must be made prior to the expiration date established in the guarantee. In preparing this guarantee, the employer might consider adding the following text to the form, at the end of the penultimate paragraph: "The Guarantor agrees to a one-time extension of this guarantee for a period not to exceed [6 months][1 year], in response to the Employer's written request for such extension, such request to be presented to the Guarantor before the expiry of the guarantee." 
This guarantee is subject to the Uniform Rules for Demand Guarantees (URDG) 2010 Revision, ICC Publication No. 758, except that the supporting statement under Article 15(a) is hereby excluded. ${ }^{5}$

[Signature(s) and seal of bank (where appropriate)]

\section{Note to Bidder}

If the bank issuing advance payment security is located outside the Employer's country, it shall be counter-guaranteed or encashable by a bank in the Employer's country.

$5 \quad$ Or the employer may use "Uniform Rules for Demand Guarantees (URDG), ICC Publication No. 458, except that subparagraph (ii) of Sub-article 20(a) is hereby excluded" as appropriate. 


\section{SBD Plant: \\ Two-Stage Bidding Procedure}

In the two-stage bidding procedure, Bidders first submit their technical proposals, in accordance with the specifications, but without prices. The technical proposals are opened at the date and time advised in the Bidding Document. The technical proposals are evaluated and may be discussed with the Bidders. Deficiencies, extraneous provisions, and unsatisfactory technical features are pointed out to the Bidders whose comments are carefully evaluated. The Bidders are allowed to revise or adjust their technical proposals to meet the requirements of the Employer. The objective of this process is to ensure that all technical proposals conform to the same acceptable technical standard and meet the technical solution required by the Employer. Bidders who are unable or unwilling to bring their Bids to the acceptable technical standard may be rejected as deficient Bids.

After the evaluation of technical proposals has been approved by ADB, the second stage is to invite Bidders to submit price proposals and revised technical proposals in compliance with the acceptable technical standard. The revised technical proposals and price proposals are opened in public at a date and time advised by the Employer. In setting the date, the Employer should allow sufficient time for Bidders to incorporate the changes involved in the technical proposals and prepare price proposals. The price proposals and revised technical proposals are evaluated, and following ADB's approval, the contract is awarded to the Bidder whose Bid has been determined to be the lowest evaluated substantially responsive Bid.

The following documents structure flowchart shows how the Bidding Document is intended to be used both during the bidding process and during the formulation of the eventual contract documents. 


\section{SBD Plant: \\ Two-Stage Bidding Procedure}

Documents Structure Flowchart

\begin{tabular}{|l|l|}
\hline \multicolumn{1}{|c|}{ Bidding Document } & \multicolumn{1}{|c|}{ Issued by Employer } \\
\cline { 2 - 3 } & $\begin{array}{l}\text { Section 1 - Instructions to Bidders (ITB) } \\
\text { Section 2 - Bid Data Sheet (BDS) } \\
\text { Section 3 - Evaluation and Qualification Criteria (EQC) } \\
\text { Section 4 - Bidding Forms (BDF) } \\
\text { Section 5 - Eligible Countries (ELC) } \\
\text { Section 6 - Employer's Requirements (ERQ) } \\
\text { Section 7 - General Conditions of Contract (GCC) } \\
\text { Section 8 - Special Conditions of Contract (SCC) } \\
\text { Section 9 - Contract Forms (COF) }\end{array}$ \\
\hline
\end{tabular}

\begin{tabular}{|l|l|l|}
\hline \multicolumn{1}{|c|}{ The First-Stage Bid } & Submitted by Bidder \\
\hline a) & The Letter of First-Stage Bid \\
b) Alternative Bids in accordance with ITB 13 & c) Written confirmation authorizing the signatory of the Bid to commit the Bidder, in \\
accordance with ITB 18.2 & d) Documentary evidence in accordance with ITB 14 that the plant and services offered by \\
the Bidder in its bid or in any alternative bid are eligible \\
e) Documentary evidence in accordance with ITB 15, the Bidder's eligibility and qualifications \\
to perform the contract if its Bid is accepted \\
f) Technical Proposal in accordance with ITB 17 \\
g) Documentary evidence in accordance with ITB 16 that the plant and services offered by \\
the Bidder conform to the Bidding Document and/or details of deviations in accordance \\
with ITB 16.2 \\
h) In the case of a bid submitted by a Joint Venture, Joint Venture agreement, or letter of \\
intent to enter into a Joint Venture, including a draft agreement, indicating at least the \\
parts of the Plant to be executed by the respective partners \\
i) List of Subcontractors, in accordance with ITB 17.2 \\
j) Any other document required in the BDS
\end{tabular}




\section{Clarification of First-Stage Bid}

Issued by Employer

a) Memorandum entitled "Changes Required Pursuant to First-Stage Evaluation"

b) Invitation for Second-Stage Bids

c) Any Addendum to the Bidding Document in accordance with ITB 8, if so required

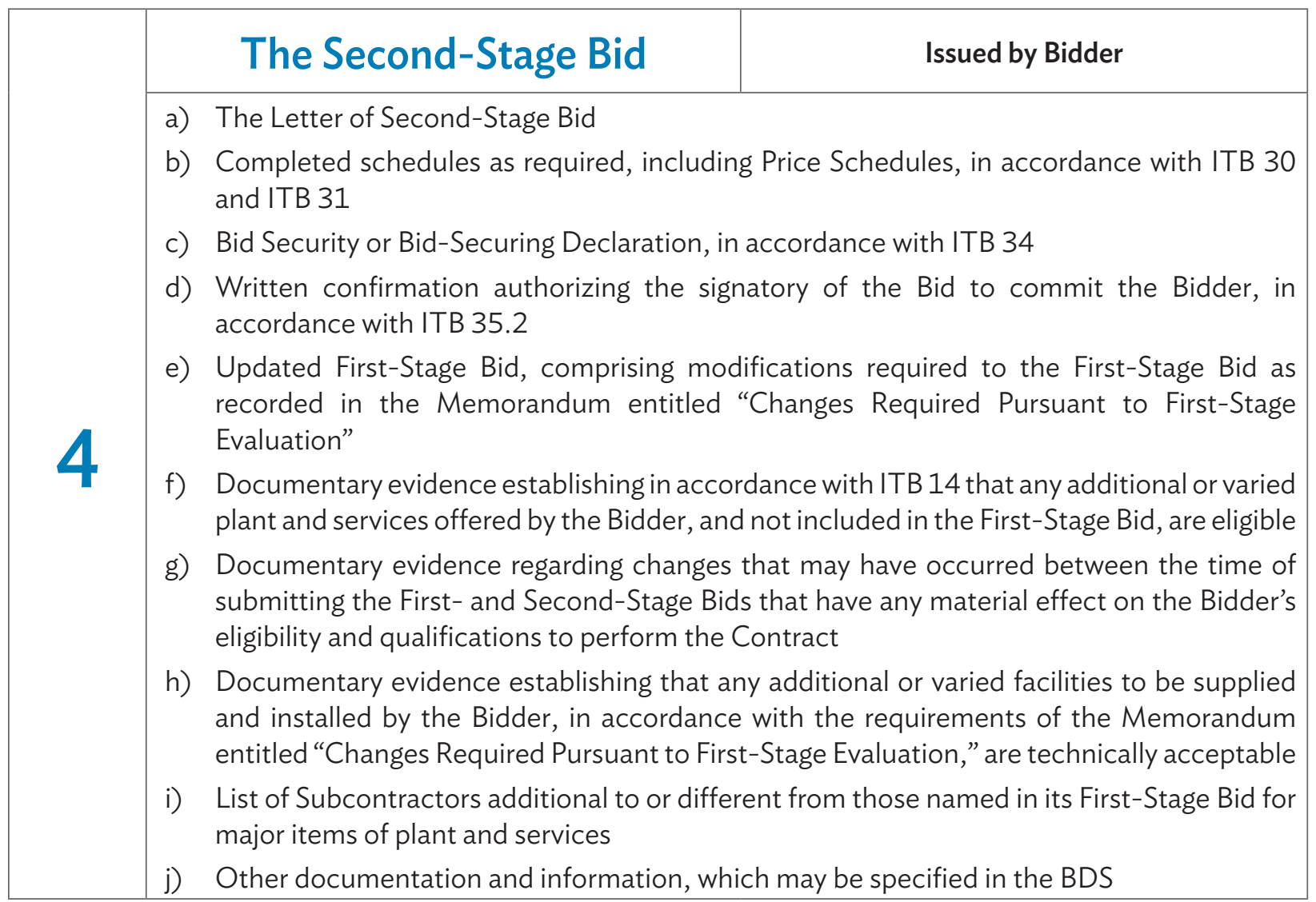

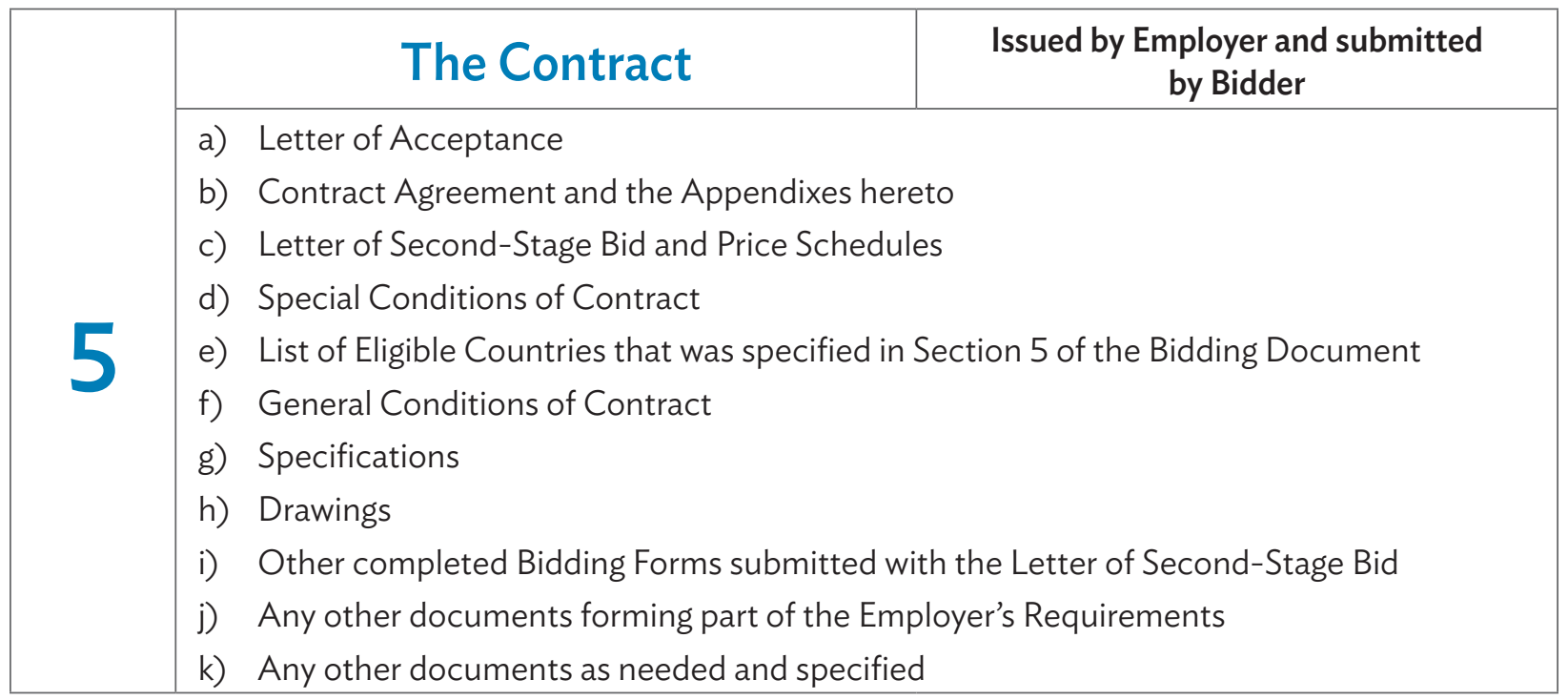




\section{Section 1: Instructions to Bidders}

This section specifies the course of actions to be taken by Bidders in the preparation and submission of their Bids following a Two-Stage bidding procedure. Information is also provided on the submission, opening, and evaluation of bids and on the award of contract.

\section{Table of Clauses}

1. Scope of Bid 264

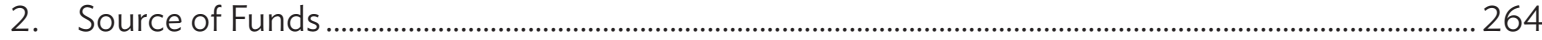

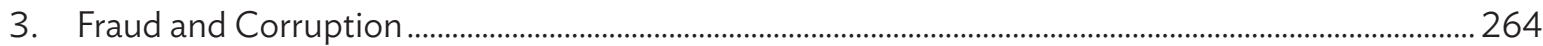

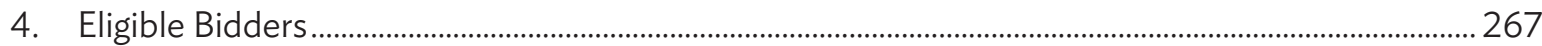

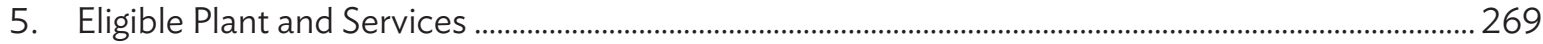

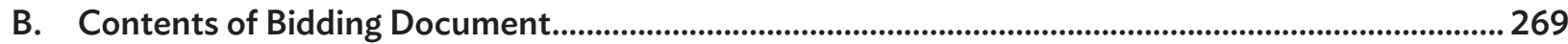

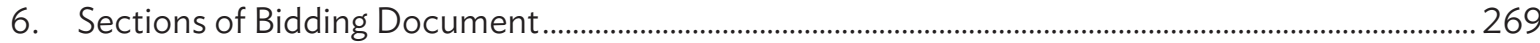

7. Clarification of Bidding Document, Site Visit, Pre-Bid Meeting .......................................................... 270

8. Amendment of Bidding Document ........................................................................................................ 271

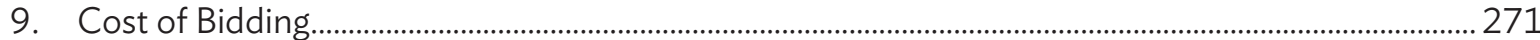

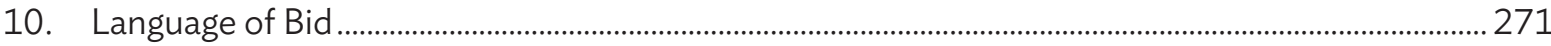

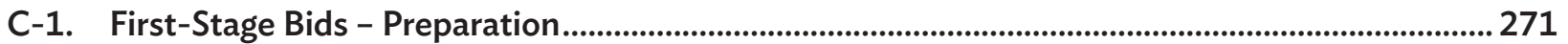

11. Documents Comprising the First-Stage Bid............................................................................................. 271

12. Letter of First-Stage Bid and Attachments .............................................................................................. 272

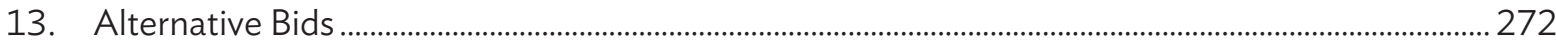

14. Documents Establishing the Eligibility of Plant and Services................................................................... 272

15. Documents Establishing the Eligibility and Qualifications of the Bidder ...........................................2 272

16. Documents Establishing Conformity of the Plant and Services ............................................................ 272 


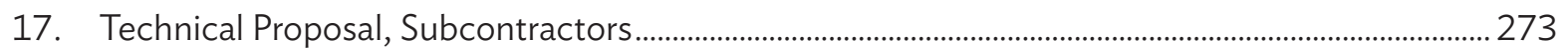

18. Format and Signing of First-Stage Bids.................................................................................................... 274

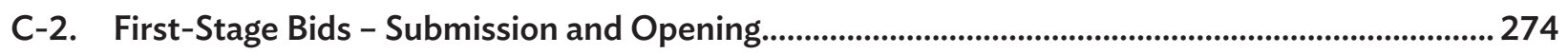

19. Submission, Sealing, and Marking of First-Stage Bids ........................................................................... 274

20. Deadline for Submission of First-Stage Bids ................................................................................ 275

21. Substitution and Modification of First-Stage Bids ................................................................................ 275

22. Opening of First-Stage Bids by Employer....................................................................................... 275

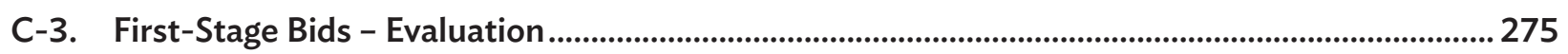

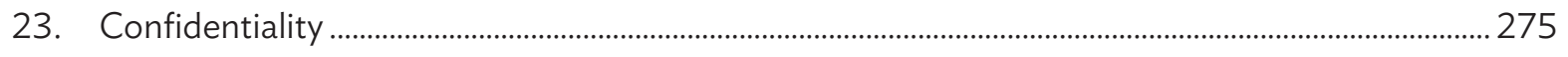

24. Determination of Responsiveness of First-Stage Bids ...................................................................... 276

25. Technical Evaluation of First-Stage Bids........................................................................................................ 276

26. Eligibility and Qualification of the Bidder ............................................................................................... 277

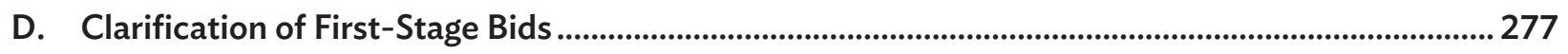

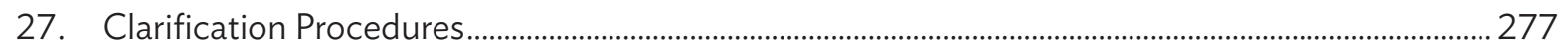

28. Invitation to Submit Second-Stage Bids ............................................................................................. 279

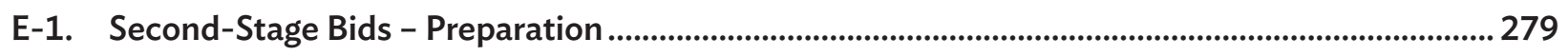

29. Documents Comprising Second-Stage Bid ............................................................................................ 279

30. Letter of Second-Stage Bid and Schedules .......................................................................................... 280

31. Bid Prices and Discounts ............................................................................................................................ 281

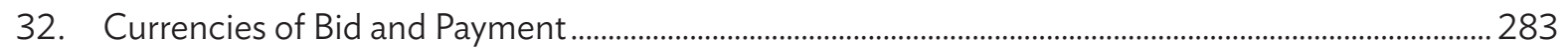

33. Period of Validity of Second-Stage Bids .................................................................................................. 283

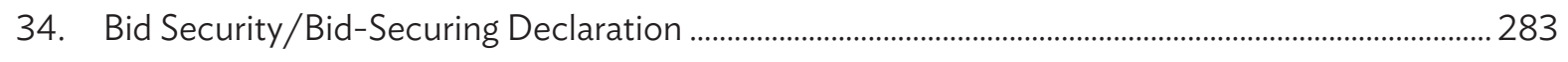

35. Format and Signing of Second-Stage Bid .................................................................................... 285 


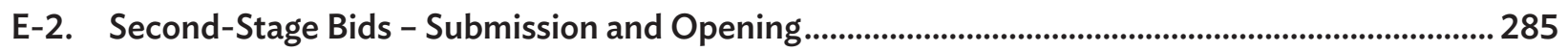

36. Submission, Sealing, and Marking of Second-Stage Bids ....................................................................... 285

37. Deadline for Submission of Second-Stage Bids .................................................................................... 286

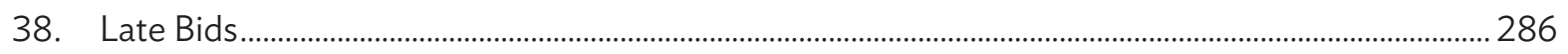

39. Withdrawal, Substitution, and Modification of Second-Stage Bids .................................................... 286

40. Second-Stage Bid Opening.............................................................................................................................. 286

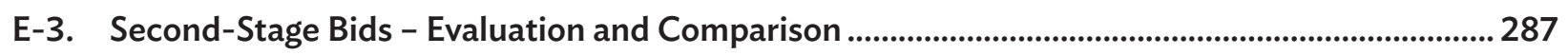

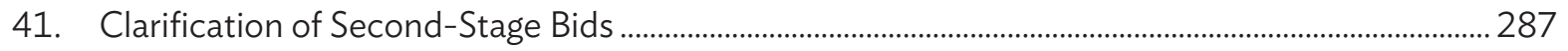

42. Deviations, Reservations, and Omissions ................................................................................................ 288

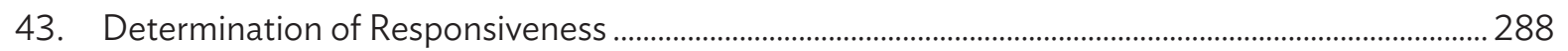

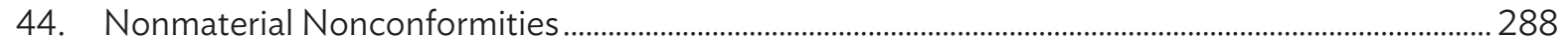

45. Correction of Arithmetical Errors ................................................................................................................... 289

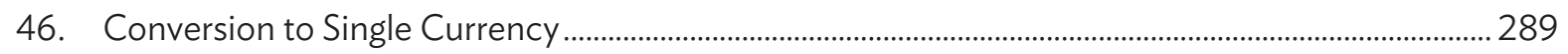

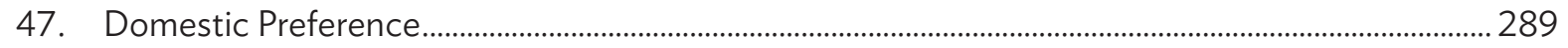

48. Evaluation and Comparison of Second-Stage Bids .............................................................................. 290

49. Abnormally Low Second-Stage Bids ....................................................................................................... 291

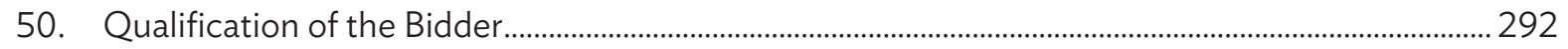

51. Employer's Right to Accept Any Bid, and to Reject Any or All Bids..................................................... 292

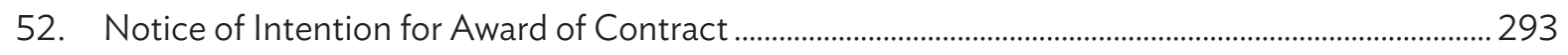

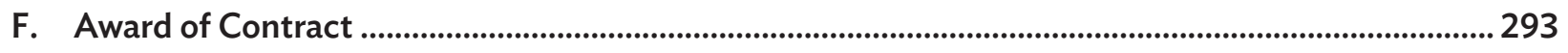

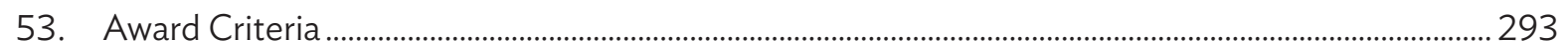

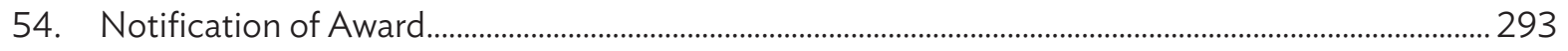

55. Signing of Contract.................................................................................................................................. 294

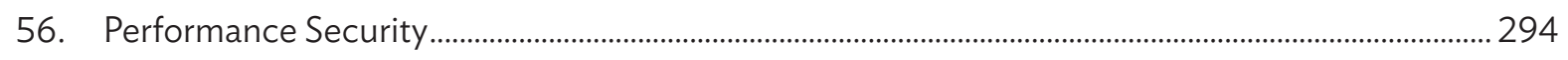

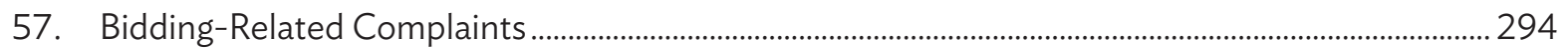


A. General

1. Scope of Bid

2. Source of Funds

\section{Fraud and Corruption}

1.1 In connection with the Invitation for Bids (IFB) indicated in the Bid Data Sheet (BDS), the Employer, as indicated in the BDS, issues this Bidding Document for the procurement of plant and services as specified in Section 6 (Employer's Requirements). The name, identification, and number of lot(s) or contract(s) of the open competitive bidding (OCB) are provided in the BDS.

1.2 Throughout this Bidding Document,

(a) the term "in writing" means communicated in written form and delivered against receipt;

(b) except where the context requires otherwise, words indicating the singular also include the plural and words indicating the plural also include the singular; and

(c) "day" means calendar day.

2.1 The Borrower or Recipient (hereinafter called "Borrower") indicated in the BDS has applied for or received financing (hereinafter called "funds") from the Asian Development Bank (hereinafter called "ADB") toward the cost of the project named in the BDS. The Borrower intends to apply a portion of the funds to eligible payments under the contract(s) for which this Bidding Document is issued.

2.2 Payments by ADB will be made only at the request of the Borrower and upon approval by $A D B$ in accordance with the terms and conditions of the Financing Agreement between the Borrower and ADB (hereinafter called "Financing Agreement"), and will be subject in all respects to the terms and conditions of that Financing Agreement. No party other than the Borrower shall derive any rights from the Financing Agreement or have any claim to the funds.

3.1 ADB requires Borrowers (including beneficiaries of ADB-financed activity) and their personnel, as well as firms and individuals participating in an ADB-financed activity, including but not limited to, Bidders, Suppliers, and Contractors, agents, subcontractors, subconsultants, service providers, subsuppliers, manufacturers (including their respective officers, directors, employees, and personnel) under ADB-financed contracts to observe the highest standard of ethics during the procurement and execution of such contracts in accordance with ADB's Anticorruption Policy (1998, as amended from time to time). In pursuance of this policy, $A D B$

(a) defines, for the purposes of this provision, the terms set forth below as follows:

(i) "corrupt practice" means the offering, giving, receiving, or soliciting, directly or indirectly, anything of value to influence improperly the actions of another party;

(ii) "fraudulent practice" means any act or omission, including a misrepresentation, that knowingly or recklessly misleads, or attempts to mislead, a party to obtain a financial or other benefit or to avoid an obligation;

(iii) "coercive practice" means impairing or harming, or threatening to impair or harm, directly or indirectly, any party or the property of the party to influence improperly the actions of a party; 
(iv) "collusive practice" means an arrangement between two or more parties designed to achieve an improper purpose, including influencing improperly the actions of another party;

(v) "abuse" means theft, waste, or improper use of assets related to ADB-related activity, either committed intentionally or through reckless disregard;

(vi) "conflict of interest" means any situation in which a party has interests that could improperly influence that party's performance of official duties or responsibilities, contractual obligations, or compliance with applicable laws and regulations; and

(vii) "integrity violation" is any act, as defined under ADB's Integrity Principles and Guidelines (2015, as amended from time to time), which violates ADB's Anticorruption Policy, including(i) to(vi) above and the following: obstructive practice, violations of $A D B$ sanctions, retaliation against whistleblowers or witnesses, and otherviolations of ADB's Anticorruption Policy, including failure to adhere to the highest ethical standard.

(b) will reject a proposal for award if it determines that the Bidder recommended for award or any of its officers, directors, employees, personnel, subconsultants, subcontractors, service providers, suppliers or manufacturers has, directly or through an agent, engaged in corrupt, fraudulent, collusive, coercive, or obstructive practices or other integrity violations in competing for the Contract;

(c) will cancel the portion of the financing allocated to a contract if it determines at any time that representatives of the borrower or of a beneficiary of ADB-financing engaged in corrupt, fraudulent, collusive, coercive, or obstructive practices or other integrity violations during the procurement or the execution of that contract, without the borrower having taken timely and appropriate action satisfactory to ADB to remedy the situation, including by failing to inform ADB in a timely manner at the time they knew of the integrity violations;

(d) will impose remedial actions on a firm or an individual, at any time, in accordance with ADB's Anticorruption Policy and Integrity Principles and Guidelines, including declaring ineligible, either indefinitely or for a stated period of time, to participate ${ }^{1}$ in ADB-financed, -administered, or -supported activities or to benefit from an ADB-financed,-administered, or-supported contract, financially or otherwise, if it at any time determines that the firm or individual has, directly or through an agent, engaged in corrupt, fraudulent, collusive, coercive or obstructive practices, or other integrity violations; and

Whether as a Contractor, Subcontractor, Consultant, Manufacturer or Supplier, or Service Provider; or in any other capacity (different names are used depending on the particular Bidding Document). 
(e) will have the right to require that a provision be included in the Bidding Document and in contracts financed, administered, or supported by $A D B$, requiring Bidders, suppliers, and contractors, consultants, manufacturers, service providers, and other third parties engaged or involved in ADB-related activities, and their respective officers, directors, employees, and personnel, to permit $A D B$ or its representative to inspect the site, their assets, accounts and records and other documents relating to the bid submission and contract performance and to have them audited by auditors appointed by ADB.

3.2 All Bidders, consultants, contractors, suppliers, manufacturers, service providers, and other third parties engaged or involved in ADB-related activities, and their respective officers, directors, employees, and personnel, are obliged to cooperate fully in any screening or investigation when requested by $A D B$ to do so. As determined on a case by case basis by ADB, such cooperation includes, but is not limited to, the following:

(a) being available to be interviewed and replying fully and truthfully to all questions asked;

(b) providing ADB with any items requested that are within the party's control including, but not limited to, documents and other physical objects;

(c) upon written request by $A D B$, authorizing other related entities to release directly to $A D B$ such information that is specifically and materially related, directly or indirectly, to the said entities or issues which are the subject of the investigation;

(d) cooperating with all reasonable requests to search or physically inspect their person and/or work areas, including files, electronic databases, and personal property used on ADB activities, or that utilizes ADB's Information and Communications Technology (ICT) resources or systems (including mobile phones, personal electronic devices, and electronic storage devices such as external disk drives);

(e) cooperating in any testing requested by $A D B$, including but not limited to, fingerprint identification, handwriting analysis, and physical examination and analysis; and

(f) preserving and protecting confidentiality of all information discussed with, and as required by, ADB.

3.3 All Bidders, consultants, contractors and suppliers shall require their officers, directors, employees, personnel, agents to ensure that, in its contract with its subconsultants, subcontractors, and other third parties engaged or involved in ADB-related activities, such subconsultants, subcontractors, and other third parties similarly are obliged to cooperate fully in any investigation when requested by $\mathrm{ADB}$ to do so. 
3.4 The Employer hereby puts the Bidder on notice that the Bidder or any Joint Venture partner of the Bidder (if any) may not be able to receive any payments under the Contract if the Bidder or any of its Joint Venture partners, as appropriate, is, or is owned (in whole or in part) by a person or entity subject to applicable sanctions.

3.5 Furthermore, Bidders shall be aware of the provision stated in GCC 9.6 and GCC 42.2.1[c].

4. Eligible Bidders

4.1 A Bidder may be a natural person, private entity, or government-owned enterprise subject to ITB 4.5-or any combination of them with a formal intent to enter into an agreement or under an existing agreement in the form of a Joint Venture. In the case of a Joint Venture,

(a) all partners shall be jointly and severally liable; and

(b) the Joint Venture shall nominate a Representative who shall have the authority to conduct all business for and on behalf of any and all the partners of the Joint Venture during the bidding process and, in the event the Joint Venture is awarded the Contract, during contract execution.

4.2 A Bidder, and all partners constituting the Bidder, shall have the nationality of an eligible country, in accordance with Section 5 (Eligible Countries). A Bidder shall be deemed to have the nationality of a country if the Bidder is a citizen or is constituted, incorporated, or registered, and operates in conformity with the provisions of the laws of that country. This criterion shall also apply to the determination of the nationality of proposed Subcontractors or Suppliers for any part of the Contract including related services.

4.3 A Bidder shall not have a conflict of interest. All Bidders found to have a conflict of interest shall be disqualified. A Bidder may be considered to be in a conflict of interest with one or more parties in this bidding process if any of, including but not limited to, the following apply:

(a) they have controlling shareholders in common; or

(b) they receive or have received any direct or indirect subsidy from any of them; or

(c) they have the same legal representative for purposes of this bid; or

(d) they have a relationship with each other, directly or through common third parties, that puts them in a position to have access to material information about or improperly influence the bid of another Bidder, or influence the decisions of the Employer regarding this bidding process; or

(e) a Bidder participates in more than one bid in this bidding process, either individually or as a partner in a Joint Venture, except for alternative offers permitted under ITB 13. This will result in the disqualification of all Bids in which it is involved. However, subject to any finding of a conflict of interest in terms of ITB 4.3(a)-(d) above, this does not limit the participation of a Bidder as a Subcontractor in another bid or of a firm as a Subcontractor in more than one bid; or 
(f) a Bidder, Joint Venture partner, associates, parent company, or any affiliated entity, participated as a consultant in the preparation of the design or technical specifications of the plant and services that are the subject of the bid; or

(g) a Bidder was affiliated with a firm or entity that has been hired (or is proposed to be hired) by the Employer or Borrower as Project Manager for the contract; or

(h) a Bidder would be providing goods, works, or nonconsulting services resulting from or directly related to consulting services for the preparation or implementation of the project specified in the BDS ITB 2.1 that it provided or were provided by any affiliate that directly or indirectly controls, is controlled by, or is under common control with that firm; or

(i) a Bidder that has a financial or familial relationship with staff of the Employer including project implementing/executing agency, or of a recipient of a part of the loan who: (i) are directly or indirectly involved in the preparation of the bidding documents or specifications of the contract, and/or the bid evaluation process of such contract; or (ii) would be involved in the implementation or supervision of such contract unless the conflict stemming from such relationship has been resolved in a manner acceptable to ADB throughout the procurement process and execution of the contract.

4.4 A firm will not be eligible to participate in any procurement activities under an ADB-financed, -administered, or -supported project while under temporary suspension or debarment by $A D B$ pursuant to its Anticorruption Policy (see ITB 3), whether such debarment was directly imposed by ADB, or enforced by ADB pursuant to the Agreement for Mutual Enforcement of Debarment Decisions. A bid from a temporary suspended or debarred firm will be rejected and such bid may be in breach of debarment conditions, thereby subject to further ADB's investigation.

4.5 Government-owned enterprises in the Borrower's country shall be eligible only if they can establish that they (i) are legally and financially autonomous, (ii) operate under commercial law, and (iii) are not dependent agencies of the Employer.

4.6 A Bidder shall not be under suspension from Bidding by the Employer as the result of the execution of a Bid-Securing Declaration.

4.7 Bidders shall provide such evidence of their continued eligibility satisfactory to the Employer, as the Employer shall reasonably request.

4.8 Bidders shall be excluded if, by an act of compliance with a decision of the United Nations Security Council taken under Chapter VII of the Charter of the United Nations, the Borrower's country prohibits any import of goods from, or payments to, a particular country, person, or entity in respect of goods or services originating in that country. Where the Borrower's country prohibits payments to a particular person or entity or for particular goods or services by such an act of compliance, that firm shall be excluded. 
5. Eligible Plant and Services
5.1 The plant and services to be supplied under the Contract shall have their origin in eligible source countries as defined in ITB 4.2, and all expenditures under the Contract will be limited to such plant and services.

5.2 For purposes of ITB 5.1 above, "origin" means the place where the plant, or component parts thereof are mined, grown, produced, or manufactured, and from which the services are provided. Plant components are produced when, through manufacturing, processing, or substantial or major assembling of components, a commercially recognized product results that differs substantially in its basic characteristics or in purpose or utility from its components.

\section{B. Contents of Bidding Document}

6. Sections of Bidding Document
6.1 The Bidding Document consists of Parts I, II, and III, which include all the Sections indicated below, and should be read in conjunction with any addenda issued in accordance with ITB 8.

\section{PART I Bidding Procedures}

- Section 1 Instructions to Bidders(ITB)

- Section 2 Bid Data Sheet (BDS)

- Section 3 Evaluation and Qualification Criteria (EQC)

- Section 4 Bidding Forms (BDF)

- Section 5 Eligible Countries (ELC)

\section{PART II Requirements}

- Section 6 Employer's Requirements (ERQ)

\section{PART III Conditions of Contract and Contract Forms}

- Section 7 General Conditions of Contract (GCC)

- Section 8 Special Conditions of Contract (SCC)

- Section 9 Contract Forms (COF)

6.2 The IFB issued by the Employer is not part of the Bidding Document.

6.3 The Employer is not responsible for the completeness of the Bidding Document and its addenda, if they were not obtained directly from the source stated by the Employer in the IFB.

6.4 The Bidder is expected to examine all instructions, forms, terms, and specifications in the Bidding Document. Failure to furnish all information or documentation required by the Bidding Document may result in rejection of the bid. 
7. Clarification of Bidding Document, Site Visit, Pre-Bid Meeting
7.1 A prospective Bidder requiring any clarification of the Bidding Document shall contact the Employer in writing at the Employer's address indicated in the BDS or raise inquiries during the pre-bid meeting if provided for in accordance with ITB 7.4. The Employer will respond to any request for clarification, provided that such request is received no later than 21 days prior to the deadline for submission of bids. The Employer's response shall be in writing with copies to all Bidders who have acquired the Bidding Document in accordance with ITB 6.3, including a description of the inquiry but without identifying its source. Should the Employer deem it necessary to amend the Bidding Document as a result of a request for clarification, it shall do so following the procedure under ITB 8, ITB 20.2, and ITB 37.2.

7.2 The Bidder is advised to visit and examine the site where the plant is to be installed and its surroundings and obtain for itself on its own responsibility all information that may be necessary for preparing the Bid and entering into a contract for the provision of plant and services. The cost of visiting the site shall be at the Bidder's own expense.

7.3 The Bidder and any of its personnel or agents will be granted permission by the Employer to enter its premises and lands for the purpose of such visit, but only upon the express condition that the Bidder, its personnel, and agents, will release and indemnify the Employer and its personnel and agents from and against all liability in respect thereof, and will be responsible for death or personal injury, loss of or damage to property, and any other loss, damage, costs, and expenses incurred as a result of the inspection.

7.4 The Bidder's designated representative is invited to attend a pre-bid meeting, if provided for in the BDS. The purpose of the meeting will be to clarify issues and to answer questions on any matter that may be raised at that stage.

7.5 The Bidder is requested to submit any questions in writing, to reach the Employer not later than 1 week before the meeting.

7.6 Minutes of the pre-bid meeting, including the text of the questions raised, without identifying the source, and the responses given, together with any responses prepared after the meeting, will be transmitted promptly to all Bidders who have acquired the Bidding Document in accordance with ITB 6.3. Any modification to the Bidding Document that may become necessary as a result of the pre-bid meeting shall be made by the Employer exclusively through the issue of an Addendum pursuant to ITB 8 and not through the minutes of the pre-bid meeting.

7.7 Nonattendance at the pre-bid meeting will not be a cause for disqualification of a Bidder. 
8. Amendment of Bidding Document

9. Cost of Bidding 9.1 The Bidder shall bear all costs associated with the preparation and submission of its Bid, and the Employer shall in no case be responsible or liable for those costs, regardless of the conduct or outcome of the bidding process.

10. Language of Bid

8.1 At any time prior to the deadline for submission of bids, the Employer may amend the Bidding Document by issuing addenda.

8.2 Any addendum issued shall be part of the Bidding Document and shall be communicated in writing to all who have obtained the Bidding Document from the Employer in accordance with ITB 6.3.

8.3 To give prospective Bidders reasonable time in which to take an addendum into account in preparing their bids, the Employer may, at its discretion, extend the deadline for the submission of bids, pursuant to ITB 20.2 and/or ITB 37.2.

10.1 The Bid, as well as all correspondence and documents relating to the bid exchanged by the Bidder and the Employer, shall be written in the language specified in the BDS. Supporting documents and printed literature that are part of the Bid may be in another language provided they are accompanied by an accurate translation of the relevant passages in the language specified in the BDS, in which case, for purposes of interpretation of the Bid, such translation shall govern.

\section{C-1. First-Stage Bids - Preparation}

11. Documents Comprising the First-Stage Bid
11.1 The First-Stage Bid submitted by the Bidder shall comprise the following:

(a) The Letter of First-Stage Bid;

(b) alternative Bids in accordance with ITB 13;

(c) written confirmation authorizing the signatory of the Bid to commit the Bidder, in accordance with ITB 18.2;

(d) documentary evidence in accordance with ITB 14 that the plant and services offered by the Bidder in its bid or in any alternative bid are eligible;

(e) documentary evidence in accordance with ITB 15, the Bidder's eligibility and qualifications to perform the contract if its Bid is accepted;

(f) Technical Proposal in accordance with ITB 17;

(g) documentary evidence in accordance with ITB 16, that the plant and services offered by the Bidder conform to the Bidding Document and/or details of deviations in accordance with ITB 16.2;

(h) list of subcontractors, in accordance with ITB 17.2; and

(i) any other document required in the BDS. 
11.2 In addition to the requirements under ITB 11.1, bids submitted by a Joint Venture shall include a copy of the Joint Venture Agreement entered into by all partners. Alternatively, a Letter of Intent to execute a Joint Venture Agreement in the event of a successful bid shall be signed by all partners and submitted with the bid, together with a copy of the proposed agreement.

11.3 First-Stage Bids are unpriced proposals and shall contain no prices or price schedules or other reference to rates and prices for completing the facilities. First-Stage Bids containing such price information will be rejected.

12. Letter of First-Stage Bid and Attachments

13. Alternative Bids

14. Documents Establishing the Eligibility of Plant and Services

15. Documents Establishing the Eligibility and Qualifications of the Bidder

16. Documents Establishing Conformity of the Plant and Services
12.1 The Letter of First-Stage Bid and any attachment shall be prepared using the relevant forms furnished in Section 4 (Bidding Forms). The forms must be completed as instructed in each form.

13.1 Bidders shall note that they are permitted to propose technical alternatives or other alternative Bids with their First-Stage Bids in addition to or in lieu of the requirements specified in the Bidding Documents, provided they can document that the proposed alternative Bids are to the benefit of the Employer, that they fulfill the principal objectives of the contract, and that they meet the basic performance and technical criteria specified in the Bidding Document.

13.2 Any alternative bid proposed by Bidders in their First-Stage Bid will be the subject of clarification with the Bidder, pursuant to ITB 27.

14.1 To establish the eligibility of the plant and services in accordance with ITB 5, Bidders shall complete the Country of Origin Declaration Form included in Section 4 (Bidding Forms).

15.1 To establish its eligibility and qualifications to perform the Contract in accordance with Section 3 (Evaluation and Qualification Criteria), the Bidder shall provide the information requested in the corresponding information sheets included in Section 4 (Bidding Forms).

15.2 Domestic Bidders, individually or in Joint Ventures, applying for eligibility for domestic preference shall supply all information required to satisfy the criteria for eligibility as described in ITB 47.

16.1 The documentary evidence of the conformity of the plant and services to the Bidding Document may be in the form of literature, drawings, and data, and shall furnish

(a) a detailed description of the essential technical and performance characteristics of the plant and services, including the functional guarantees of the proposed plant and services, in response to the specification; 
(b) a list giving full particulars, including available sources, of all spare parts, special tools, etc., necessary for the proper and continuing functioning of the plant for the period stated in the BDS, following completion of plant and services in accordance with provisions of the contract; and

(c) a commentary on the Employer's Specifications and adequate evidence demonstrating the substantial responsiveness of the plant and services to those specifications. Bidders shall note that standards for workmanship, materials, and equipment designated by the Employer in the Bidding Document are intended to be descriptive (establishing standards of quality and performance) only and not restrictive. The Bidder may substitute alternative standards, brand names, and/or catalog numbers in its Bid, provided that it demonstrates to the Employer's satisfaction that the substitutions are substantially equivalent or superior to the standards designated in the Specifications.

16.2 Bidders shall give details of deviations, objections, or reservations, other than alternative Bids, from the requirements of the Bidding Document, that they would like the Employer to consider during the clarification of the First-Stage Bid with the Bidder, pursuant to ITB 27. In particular, deviations from objections to or reservations, if any, about critical provisions, such as those concerning GCC Clauses 5 (Governing Law), 14 (Taxes and Duties), 27 (Defect Liability), 28 (Functional Guarantees), 29 (Patent Indemnity), or 30 (Limitation of Liability); and related prescriptions in the Bidding Document, shall be explained. The Employer will consider all deviations, pursuant to ITB 25. Those accepted by the Employer will be incorporated either as an amendment to the Bidding Document, or into the "Changes Required Pursuant to First-Stage Evaluation," pursuant to ITB 27.8. The deviations that will not be accepted by the Employer shall be withdrawn by the Bidder in its Second-Stage Bid, failing which the Bid will be rejected, pursuant to ITB 43.

\section{Technical Proposal, Subcontractors}

17.1 The Bidder shall furnish a Technical Proposal, including a statement of work methods, equipment, personnel, schedule, environmental, health and safety (EHS) management plan commensurate with the proposed scope of works, EHS Code of Conduct and any other information as stipulated in Section 4 (Bidding Forms), in sufficient detail to demonstrate the adequacy of the Bidders' proposal to meet the Employer's requirements and the completion time.

17.2 For major items of plant and services as listed by the Employer in Criterion 2.5 of Section 3 (Evaluation and Qualification Criteria), which the Bidder intends to purchase or subcontract, the Bidder shall give details of the name and nationality of the proposed Subcontractors, including Manufacturers, for each of those items. In addition, the Bidder shall include in its Bid information establishing compliance with the requirements specified by the Employer for these items. Bidders are free to list more than one Subcontractor against each item of the plant and services.

17.3 The Bidder shall be responsible for ensuring that any Subcontractor proposed complies with the requirements of ITB 4, and that any plant or services to be provided by the Subcontractor comply with the requirements of ITB 5 and ITB 15.1. 
18. Format and Signing of First-Stage Bids

18.1 The Bidder shall prepare one original set of the documents comprising the Bid as described in ITB 11 and clearly mark it "FIRST-STAGE BID - ORIGINAL." Alternative Bids, if permitted in accordance with ITB 13, shall be clearly marked "FIRST-STAGE BID - ALTERNATIVE". In addition, the Bidder shall submit copies of the Bid, in the number specified in the BDS and clearly mark them "FIRST-STAGE BID - COPY." In the event of any discrepancy between the original and the copies, the original shall prevail.

18.2 The original and all copies of the Bid shall be typed or written in indelible ink and shall be signed by a person duly authorized to sign on behalf of the Bidder. This authorization shall consist of a written confirmation as specified in the BDS and shall be attached to the Bid. The name and position held by each person signing the authorization must be typed or printed below the signature. If a Bidder submits a deficient authorization, the Bid shall not be rejected in the first instance. The Employer shall request the Bidder to submit an acceptable authorization within the number of days as specified in the BDS. Failure to provide an acceptable authorization within the period stated in the Employer's request shall cause the rejection of the Bid. If the Letter of First-Stage Bid is not signed, the Bid shall be rejected.

18.3 A Bid submitted by a Joint Venture shall be signed so as to be legally binding on all partners.

18.4 Any amendments such as interlineations, erasures, or overwriting, shall be valid only if they are signed or initialed by the person signing the Bid.

\section{C-2. First-Stage Bids - Submission and Opening}

19. Submission, Sealing, and Marking of First-Stage Bids
19.1 Bidders shall submit their First-Stage Bids as specified in the BDS. Procedures for submission, sealing, and marking are as follows:

(a) Bids by mail or by hand, shall enclose the original and each copy of the Bid, including alternative Bids, if permitted in accordance with ITB 13, in separate sealed envelopes, duly marking the envelopes as "FIRSTSTAGE BID - ORIGINAL," "FIRST-STAGE BID - ALTERNATIVE" and "FIRST-STAGE BID - COPY." These envelopes containing the original and the copies shall then be enclosed in one single envelope. The rest of the procedure shall be in accordance with ITB 19.2 and ITB 19.3.

(b) Bidders submitting bids electronically shall follow the electronic bid submission procedures specified in the BDS.

19.2 The inner and outer envelopes shall

(a) bear the name and address of the Bidder,

(b) be addressed to the Employer in accordance with ITB 20.1,

(c) bear the specific identification of this bidding process indicated in the BDS 1.1, and

(d) bear a warning not to open before the time and date for bid opening. 
19.3 If all envelopes are not sealed and marked as required, the Employer will assume no responsibility for the misplacement or premature opening of the Bid.

20. Deadline for Submission of First-Stage Bids

21. Substitution and Modification of First-Stage Bids

22. Opening of First-Stage Bids by Employer
20.1 First-Stage Bids must be received by the Employer at the address and no later than the date and time indicated in the BDS. Any Bid received by the Employer after the deadline for submission of Bids shall be declared late, rejected, and returned unopened to the Bidder.

20.2 The Employer may, at its discretion, extend the deadline for the submission of First-Stage Bids by amending the Bidding Document in accordance with ITB 8, in which case all rights and obligations of the Employer and Bidders previously subject to the deadline shall thereafter be subject to the deadline as extended.

21.1 In case a Bidder wishes to substitute or modify its First-Stage Bid after it has been submitted and prior to the deadline for First-Stage Bid submission, it may do so by sending a written notice, as per ITB 20.1 and its substituted or modified Bid will be opened as per ITB 22.2.

22.1 The Employer shall open the First-Stage Bids in public at the address, on the date, and time specified in the BDS in the presence of Bidders' designated representatives and anyone who chooses to attend. Any specific electronic bid opening procedure required if electronic bidding is permitted in accordance with ITB 19.1 shall be as specified in the BDS.

22.2 The names of all Bidders who submitted First-Stage Bids will be read out, and other such details as the Employer, at its discretion, may consider appropriate, will be announced at the opening.

22.3 The Employer shall prepare a record of the First-Stage Bid opening that shall include, as a minimum, the name of the Bidder, including any alternative bids. The Bidders' representatives who are present shall be requested to sign the record. The omission of a Bidder's signature on the record shall not invalidate the contents and effect of the record. A copy of the record shall be distributed to all Bidders who submitted First-Stage Bids on time, and posted online when electronic bidding is permitted.

\section{C-3. First-Stage Bids - Evaluation}

23. Confidentiality 23.1 Information relating to the evaluation of First- and Second-Stage Bids and recommendation of contract award shall not be disclosed to Bidders or any other persons not officially concerned with such process until the publication of Contract award.

23.2 Any attempt by a Bidder to influence the Employer in the evaluation of the First- and Second-Stage Bids or Contract award decisions may result in the rejection of its Bid.

23.3 Notwithstanding ITB 23.2, from the time of First-Stage Bid opening to the time of Contract award, if any Bidder wishes to contact the Employer on any matter related to the bidding process, it should do so in writing. 
24. Determination of Responsiveness of First-Stage Bids

25. Technical Evaluation of First-Stage Bids
24.1 The Employer will examine the First-Stage Bids to determine whether they are substantially complete, whether the documents have been properly signed and whether the First-Stage Bids are generally in order. Any First-Stage Bids found to be nonresponsive or not meeting the minimum performance specifications, or not submitting the minimum information that is essential for the evaluation of the First-Stage Bid, may be rejected by the Employer and not included for further consideration. The Employer will also carry out examination of any alternative bids submitted by Bidders.

24.2 The Employer may request that the Bidder submit the necessary information or documentation, within a reasonable period of time, to rectify nonmaterial omissions in the Bid related to documentation requirements. Failure of the Bidder to comply with the request may result in the rejection of its Bid.

25.1 The Employer will carry out a detailed technical evaluation of the First-Stage Bids to determine whether the technical aspects are in compliance with the Bidding Document. To reach such a determination, the Employer will examine and compare the technical aspects of the First-Stage Bids on the basis of the information supplied by the Bidders, taking into account the following:

(a) overall completeness and compliance with the Employer's Requirements; the technical merits of alternatives offered and deviations from the Employer's Requirements; conformity of the plant and services offered with specified performance criteria, including conformity with the specified minimum and/or maximum requirements corresponding to each functional guarantee, as indicated in the Specifications and in Section 3 (Evaluation and Qualification Criteria); suitability of the plant and services offered in relation to the environmental and climatic conditions prevailing at the site; and quality, function, and operation of any process control concept included in the bid;

(b) compliance with the time schedule called for in the corresponding Appendix to the Contract Agreement and any alternative time schedules offered by Bidders, as evidenced by a milestone schedule provided in the bid;

(c) type, quantity, and long-term availability of mandatory and recommended spare parts and maintenance services;

(d) other relevant factors, if any, listed in Section 3 (Evaluation and Qualification Criteria); and

(e) any deviation to the commercial and contractual provisions stipulated in the Bidding Document.

25.2 The Employer will also review complete technical alternative bids, if any, offered by the Bidder, pursuant to ITB 13, to determine whether such alternatives may constitute an acceptable basis for a Second-Stage Bid to be submitted on its own merits. 
26. Eligibility and Qualification of the Bidder

26.1 The Employer shall determine to its satisfaction whether Bidders determined as having submitted responsive First-Stage Bids are eligible and meet the qualification criteria specified in Section 3 (Evaluation and Qualification Criteria).

26.2 The determination shall be based upon an examination of the documentary evidence of the Bidder's qualifications submitted by the Bidder, pursuant to ITB 15, and on any additional information, which the Employer may request from the Bidder to support such evidence. Unless permitted in the BDS, the determination shall not take into consideration the qualifications of other firms such as the Bidder's subsidiaries, parent entities, or affiliates.

26.3 An affirmative determination will be a prerequisite for the Employer to invite the Bidder to a clarification meeting in accordance with ITB 27. The Employer reserves the right to reject the bid of any bidder found to be in circumstances described in GCC 42.2.1(a). A negative determination will result in rejection of the Bidder's Bid.

26.4 The capabilities of the manufacturers and subcontractors proposed to be used by Bidders for Employer-identified major items of plant and services will also be evaluated for acceptability in accordance with Section 3 (Evaluation and Qualification Criteria). Subject to ITB 24, should a Manufacturer or Subcontractor be determined to be unacceptable, the Employer, through the memorandum entitled "Changes Required Pursuant to First-Stage Evaluation" that is issued together with the invitation to submit a Second-Stage Bid, shall require the invited Bidder to substitute an acceptable Manufacturer, Subcontractor, or key item.

\section{Clarification of First-Stage Bids}

27. Clarification Procedures
27.1 The Employer may conduct clarification meetings with each or any Bidder to clarify any aspects of its First-Stage Bid that require explanation and to review a Bidder's proposed deviations and alternative solutions.

27.2 The Employer may bring to the attention of the Bidder any amendments or changes that the Employer may require to be made to the First-Stage Bid; however, the Employer may not require amendments or changes at variance from the Employer's requirements unless the Employer intends to amend the Bidding Document in accordance with ITB 28.1(a).

27.3 The Employer may also seek clarifications in writing. In case the Employer has not sought clarifications in writing or through a meeting, but the Bidder wishes to explain its technical proposal, particularly its deviations and reservations, the Bidder is allowed one opportunity to request the Executing Agency for a clarification meeting. 
27.4 The Bidder's written request for a clarification meeting should be received by the Employer not later than 14 days prior to the submission deadline for Second-Stage Bids, and should provide an outline description of the particulars that the Bidder wishes to clarify with the Employer. Failure by a Bidder to meet these requirements may cause the Employer to decline the Bidder's request for clarification meeting. The option to hold the clarification meeting, however, remains with the Employer, whose decision shall be communicated to the Bidder in writing.

27.5 Bidders shall ensure that they are represented in the clarification meetings by persons who are duly authorized to conduct business for the Bidders during the bidding process.

27.6 At the end of the clarification meeting, the Employer shall issue minutes of the clarification meeting, documenting all clarifications and agreements reached during the meeting.

27.7 No agreement reached between the Employer and the Bidder during the clarification meeting shall constitute an amendment to the Bidding Document or the Employer's waiver of any requirement of the Bidding Document.

27.8 The Employer will issue a Memorandum entitled "Changes Required Pursuant to First-Stage Evaluation," documenting the clarifications made in writing and/or in a meeting, if any, and including an Annex listing all decisions, and required amendments or changes resulting from the clarification of the First-Stage Bid. The Memorandum will be communicated to the Bidder as part of the invitation to submit the Second-Stage Bid. Through this Memorandum, the Employer will

(a) advise the Bidder of any exception or deviation to the technical, commercial, or contractual provisions of the Bidding Document in the First-Stage Bid, that are unacceptable and that are to be withdrawn in the Second-Stage Bid, and of such exceptions or deviations that the Employer finds acceptable;

(b) advise the Bidder to submit for consideration in the Second Stage any Subcontractor or manufacturer that is to be replaced pursuant to ITB 26.4; and

(c) also advise the Bidder whether the proposed alternative Bid, if any, is acceptable, and will identify the degree (if any) to which such an alternative Bid may be incorporated in the Bidder's Second-Stage Bid. 
28. Invitation to Submit Second-Stage Bids
28.1 At the end of the clarification process pursuant to ITB 27, conducted as necessary,

(a) the Employer may need to issue an amendment to the Bidding Document resulting from the First-Stage evaluation and clarification process, with the objective of clarifying the requirements and improving competition without compromising essential project objectives, and/or

(b) with regard to all Bidders, the Employer will either

(i) invite the Bidder to submit a final updated technical and a commercial Second-Stage Bid based on its First-Stage Bid taking into account the Bidding Document, if and as amended, and any other modifications as recorded in the Annex to the Memorandum entitled "Changes Required Pursuant to First-Stage Evaluation." Bidders will be allowed to submit only one Second-Stage Bid, or

(ii) notify the Bidder that its Bid has been rejected on the grounds of being substantially nonresponsive, or that the Bidder does not meet the minimum qualification requirements set forth in the Bidding Document.

28.2 The deadline for submission of Second-Stage Bids will be specified in the invitation to submit Second-Stage Bids, pursuant to ITB 37.1.

28.3 Bidders are not allowed to form Joint Venture(s) or consortium (consortia) with other Bidders, nor change the partner or structure of the Joint Venture or consortium if the Bidder in the First Stage was a Joint Venture or consortium.

28.4 If, as a result of the First-Stage evaluation, only one Bidder will be determined as substantially responsive, the Second-Stage bidding process shall be annulled due to a lack of competition in the submission of priced Bids. In such a case, all First-Stage Bids submitted shall be promptly returned to Bidders.

\section{E-1. Second-Stage Bids - Preparation}

29. Documents Comprising Second-Stage Bid
29.1 The Second-Stage Bid submitted by the Bidder shall comprise the following:

(a) Letter of Second-Stage Bid;

(b) Completed schedules as required, including Price Schedules, in accordance with ITB 30 and ITB 31;

(c) Bid Security or Bid-Securing Declaration, in accordance with ITB 34;

(d) Written confirmation authorizing the signatory of the Bid to commit the Bidder, in accordance with ITB 35.2; 
(e) Updated First-Stage Bid, comprising any modifications required to the First-Stage Bid as recorded in the Memorandum entitled "Changes Required Pursuant to First-Stage Evaluation;"

(f) Documentary evidence establishing in accordance with ITB 14, that any additional or varied plant and services offered by the Bidder, and not included in the First-Stage Bid, are eligible;

(g) Documentary evidence regarding any changes that may have occurred between the time of submitting the First- and Second-Stage Bids that have any material effect on the Bidder's eligibility and qualifications to perform the Contract;

(h) Documentary evidence establishing that any additional or varied facilities to be supplied and installed by the Bidder, in accordance with the requirements of the Memorandum entitled "Changes Required Pursuant to First-Stage Evaluation," are technically acceptable. The documentary evidence of the conformity of the plant and services to the requirements of the Memorandum entitled "Changes Required Pursuant to First-Stage Evaluation" may be in the form of literature, drawings, and data;

(i) If, as a result of complying with the memorandum "Changes Required Pursuant to First-Stage Evaluation," the Bidder proposes to engage any Subcontractors or Manufacturers additional to or different from those named in its First-Stage Bid for major items of plant and services as listed by the Employer in Section 3 (Evaluation and Qualification Criteria), which the Bidder intends to purchase or subcontract, the Bidder shall give details of the name and nationality of the proposed Subcontractors, including Manufacturers, for each of those items. In addition, the Bidder shall include in its bid information establishing compliance with the requirements specified by the Employer for these items; and

(j) Other documentation and information that may be specified in the BDS.

30. Letter of Second-Stage Bid and Schedules
30.1 The Bidder shall complete the Letter of Second-Stage Bid and Schedules, including the appropriate Price Schedules, using the relevant forms furnished in Section 4 (Bidding Forms). The forms must be completed as instructed in each form and as required in the BDS. 
31. Bid Prices and Discounts
31.1 Unless otherwise specified in the BDS and/or Section 6 (Employer's Requirements), Bidders shall quote for the entire plant and services on a "single responsibility" basis such that the total Bid price covers all the Contractor's obligations mentioned in or to be reasonably inferred from the Bidding Document in respect of the design, manufacture, including procurement and subcontracting (if any), delivery, construction, installation, and completion of the plant. This includes all requirements under the Contractor's responsibilities for testing, precommissioning, and commissioning of the plant and, where so required by the Bidding Document, the acquisition of all permits, approvals, and licenses, etc.; the operation, maintenance, and training services and such other items and services as may be specified in the Bidding Document, all in accordance with the requirements of the General Conditions. Items against which no price is entered by the Bidder will not be paid for by the Employer when executed and shall be deemed to be covered by the prices for other items.

31.2 Bidders shall give a breakdown of the prices in the manner and detail called for in the Price Schedules included in Section 4 (Bidding Forms). Where no different Price Schedules are included in the Bidding Document, Bidders shall present their prices in the manner specified below. The prices for all items in the Price Schedules shall be expressed in positive values. If the prices are expressed in negative values, the bid will be rejected.

31.3 Separate numbered Schedules included in Section 4 (Bidding Forms) shall be used for each of the following elements. The total amount from each Schedule (Nos. 1 to 4) shall be summarized in a Grand Summary (Schedule No. 5), giving the total bid price(s) to be entered in the Letter of Second-Stage Bid. Absence of the total bid price in the Letter of Second-Stage Bid may result in the rejection of the Bid.

Schedule No. 1 Plant and Mandatory Spare Parts Supplied from Abroad

Schedule No. 2 Plant and Mandatory Spare Parts Supplied from Within the Employer's Country

Schedule No. 3 Design Services

Schedule No. 4 Installation and other Services

Schedule No. 5 Grand Summary (Schedule Nos. 1 to 4)

Schedule No. 6 Recommended Spare Parts

Bidders shall note that the plant and mandatory spare parts included in Schedule Nos. 1 and 2 above exclude materials used for civil, building, and other construction works. All such materials shall be included and priced under Schedule No. 4, Installation and Other Services. 
31.4 In the Schedules, Bidders shall give the required details and a breakdown of their prices as follows:

(a) Plant to be Supplied from Abroad (Schedule No. 1):

(i) the price of the plant shall be quoted CIP-named place of destination basis specified in the BDS,

(ii) all customs duties and other taxes paid or payable in the Employer's country on the plant if the contract is awarded to the Bidder, and

(iii) the total price for the plant.

(b) Plant Supplied from Within the Employer's Country (Schedule No. 2):

(i) the price of the plant shall be quoted on an EXW Incoterm basis (ex works, ex factory, ex warehouse, ex showroom, as applicable), including all customs duties and sales and other taxes already paid or payable on the components and raw material used in the manufacture or assembly of plant quoted ex works or ex factory, or on the previously imported plant of foreign origin quoted ex warehouse, ex showroom;

(ii) sales tax and other taxes payable in the Employer's country on the plant if the contract is awarded to the Bidder; and

(iii) the total price for the item.

(c) Design Services (Schedule No. 3). Rates or prices shall include all taxes, duties, levies, and charges payable in the Employer's country as of 28 days prior to the deadline for submission of Second-Stage Bids.

(d) Installation and Other Services shall be quoted separately (Schedule No. 4) and shall include rates or prices for local transportation, insurance, and other services incidental to delivery of the plant, all labor, contractor's equipment, temporary works, materials, consumables, and all matters and things of whatsoever nature, including operations and maintenance services, the provision of operations and maintenance manuals, training, etc., where identified in the Bidding Document, as necessary for the proper execution of the installation and other services, including all taxes, duties, levies, and charges payable in the Employer's country as of 28 days prior to the deadline for submission of Second-Stage Bids.

(e) Recommended spare parts shall be quoted separately (Schedule No. 6) as specified in either subparagraph (a) or (b) above in accordance with the origin of the spare parts.

31.5 The current edition of Incoterms, published by the International Chamber of Commerce shall govern. 
31.6 The prices shall be either fixed or adjustable as specified in the BDS.

(a) In the case of Fixed Price, prices quoted by the Bidder shall be fixed during the Bidder's performance of the contract and not subject to variation on any account. A bid submitted with an adjustable price quotation will be treated as nonresponsive and rejected.

(b) In the case of Adjustable Price, prices quoted by the Bidder shall be subject to adjustment during performance of the contract to reflect changes in the cost elements, such as labor, material, transport, and contractor's equipment, in accordance with the procedures specified in the corresponding Appendix to the Form of Contract Agreement. A bid submitted with a fixed price quotation will be treated as nonresponsive and be rejected. The Bidder shall furnish the indexes (e.g. for labor and materials), their weightings and source in the Tables of Adjustment Data included in Section 4 (Bidding Forms). The Employer may require the Bidder to justify its proposed indexes and weightings. Any bid that omits indexes and weightings shall be subject to clarification with the Bidder.

31.7 If so indicated in ITB 1.1, Bids are being invited for individual lots (contracts) or for any combination of lots (packages). Bidders wishing to offer any price reduction (discount) for the award of more than one Contract shall specify in their Letter of Second-Stage Bid the price reductions applicable to each package, or alternatively, to individual Contracts within the package, and the manner in which the price reductions will apply.

32. Currencies of Bid and Payment

\section{Period of Validity of Second-Stage Bids}

\section{Bid Security/ Bid-Securing Declaration}

32.1 The currency(ies) of the Bid shall be as specified in the BDS.

32.2 Bidders may be required by the Employer to justify, to the Employer's satisfaction, their local and foreign currency requirements.

33.1 Second-Stage Bids shall remain valid for the bid validity period specified in the BDS. The bid validity period starts from the date fixed for the bid submission deadline date prescribed by the Employer in accordance with ITB 37.1. A Bid valid for a shorter period shall be rejected by the Employer as nonresponsive.

33.2 In exceptional circumstances, prior to the expiration of the bid validity period, the Employer may request Bidders to extend the period of validity of their Second-Stage Bids. The request and the responses shall be made in writing. If a bid security is requested in accordance with ITB 34, it shall also be extended 28 days beyond the deadline of the extended bid validity period. A Bidder may refuse the request without forfeiting its bid security. A Bidder granting the request shall not be required or permitted to modify its Bid.

34.1 Unless otherwise specified in the BDS, the Bidder shall furnish as part of its bid, in original form, either a Bid-Securing Declaration or a bid security specified in the BDS. In the case of a bid security, the amount and currency shall be as specified in the BDS.

34.2 If a Bid-Securing Declaration is required pursuant to ITB 34.1, it shall use the form included in Section 4 (Bidding Forms). The Employer will declare a Bidder ineligible to be awarded a Contract for a specified period of time, as indicated in the BDS, if a Bid-Securing Declaration is executed. 
34.3 If a bid security is specified pursuant to ITB 34.1, the bid security shall be, at the Bidder's option, in any of the following forms:

(a) an unconditional bank guarantee (hard copy of the bank guarantee or in the form of SWIFT message MT760), or

(b) an irrevocable letter of credit, or

(c) a cashier's or certified check,

all from a reputable source from an eligible country as described in Section 5 (Eligible Countries). In the case of a bank guarantee, the bid security shall be submitted either using the Bid Security Form included in Section 4 (Bidding Forms) or another form acceptable to the Employer. The form must include the complete name of the Bidder. The bid security shall be valid for 28 days beyond the original validity period of the bid, or beyond any period of extension if requested under ITB 33.2.

34.4 Unless otherwise specified in the BDS, any Bid not accompanied by a substantially compliant bid security or bid-securing declaration, if one is required in accordance with ITB 34.1, shall be rejected by the Employer as nonresponsive.

34.5 If a bid security is specified pursuant to ITB 34.1, the bid security of unsuccessful Bidders shall be returned promptly upon the successful Bidder's furnishing of the performance security pursuant to ITB 56.

34.6 If a bid security is specified pursuant to ITB 34.1, the bid security of the successful Bidder shall be returned promptly once the successful Bidder has signed the Contract and furnished the required performance security.

34.7 The bid security may be forfeited or the Bid-Securing Declaration executed, if

(a) notwithstanding ITB 39.3, a Bidder withdraws its Bid during the period of bid validity specified by the Bidder on the Letter of Second-Stage Bid, except as provided in ITB 33.2; or

(b) the successful Bidder fails to

(i) sign the Contract in accordance with ITB 55,

(ii) furnish a performance security in accordance with ITB 56, or

(iii) accept the arithmetical corrections in accordance with ITB 45.

34.8 If the bid security is required as per ITB 34.1, the bid security of a Joint Venture shall be in the name of the Joint Venture that submits the Bid. If the Joint Venture has not been legally constituted at the time of bidding, the bid security shall be in the name of any or all of the Joint Venture partners. If the Bid-Securing Declaration is required as per ITB 34.1, the Bid-Securing Declaration of a Joint Venture shall be in the name of the Joint Venture that submits the Bid. If the Joint Venture has not been legally constituted at the time of bidding, the Bid-Securing Declaration shall be in the names of all future partners as named in the letter of intent referred to in ITB 4.1. 
35. Format and Signing of Second-Stage Bid
35.1 The Bidder shall prepare one original set of the documents comprising the bid as described in ITB 29 and clearly mark it "SECOND-STAGE BID ORIGINAL." In addition, the Bidder shall submit copies of the Bid, in the number specified in the BDS and clearly mark them "SECOND-STAGE BID - COPY." In the event of any discrepancy between the original and the copies, the original shall prevail.

35.2 The original and all copies of the Bid shall be typed or written in indelible ink and shall be signed by a person duly authorized to sign on behalf of the Bidder. This authorization shall consist of a written confirmation as specified in the BDS and shall be attached to the Bid. The name and position held by each person signing the authorization must be typed or printed below the signature. If a Bidder submits a deficient authorization, the Bid shall not be rejected in the first instance. The Employer shall request the Bidder to submit an acceptable authorization within the number of days as specified in the BDS. Failure to provide an acceptable authorization within the period stated in the Employer's request shall cause the rejection of the Bid. If either the Letter of Second-Stage Bid or the Bid-Securing Declaration (if applicable) is not signed, the Bid shall be rejected.

35.3 A bid submitted by a Joint Venture shall be signed so as to be legally binding on all partners.

35.4 Any amendments such as interlineations, erasures, or overwriting, shall be valid only if they are signed or initialed by the person signing the Bid.

\section{E-2. Second-Stage Bids - Submission and Opening}

36. Submission, Sealing, and Marking of Second-Stage Bids
36.1 Bidders shall submit their Second-Stage Bids as specified in the BDS. Procedures for submission, sealing, and marking are as follows:

(a) Bidders submitting Bids by mail or by hand shall enclose the original and each copy of the Bid, in separate sealed envelopes, duly marking the envelopes as "SECOND-STAGE BID - ORIGINAL," and "SECONDSTAGE BID - COPY." These envelopes containing the original and the copies shall then be enclosed in one single envelope. The rest of the procedure shall be in accordance with ITB 36.2 and ITB 36.3.

(b) Bidders submitting Bids electronically shall follow the electronic bid submission procedures specified in the BDS.

36.2 The inner and outer envelopes shall

(a) bear the name and address of the Bidder,

(b) be addressed to the Employer in accordance with ITB 37.1,

(c) bear the specific identification of this bidding process indicated in the BDS 1.1, and

(d) bear a warning not to open before the time and date for bid opening. 
36.3 If all envelopes are not sealed and marked as required, the Employer will assume no responsibility for the misplacement or premature opening of the Bid.

37. Deadline for Submission of Second-Stage Bids

38. Late Bids

39. Withdrawal, Substitution, and Modification of Second-Stage Bids

\section{Second-Stage Bid Opening}

37.1 Second-Stage Bids must be received by the Employer at the address and no later than the date and time indicated in the Letter of Invitation to submit Second-Stage Bids.

37.2 The Employer may, at its discretion, extend the deadline for the submission of Second-Stage Bids by amending the Bidding Document in accordance with ITB 8, in which case all rights and obligations of the Employer and Bidders previously subject to the deadline shall thereafter be subject to the deadline as extended.

38.1 The Employer shall not consider any Second-Stage Bids that arrive after the deadline for submission of Second-Stage Bids, in accordance with ITB 37. Any Bid received by the Employer after the deadline for submission of Second-Stage Bids shall be declared late, rejected, and returned unopened to the Bidder.

39.1 A Bidder may withdraw, substitute, or modify its Bid after it has been submitted by sending a written notice, duly signed by an authorized representative, and shall include a copy of the authorization in accordance with ITB 35.2 (except for withdrawal notices, which do not require copies). The corresponding substitution or modification of the Bid must accompany the respective written notice. All notices must be

(a) prepared and submitted in accordance with ITB 35 and ITB 36 (except for withdrawal notices, which do not require copies), and in addition, the respective envelopes shall be clearly marked "SECOND-STAGE BID - WITHDRAWAL," "SECOND-STAGE BID - SUBSTITUTION," "SECOND-STAGE BID - MODIFICATION"; and

(b) received by the Employer prior to the deadline prescribed for submission of Second-Stage Bids, in accordance with ITB 37.

39.2 Second-Stage Bids requested to be withdrawn in accordance with ITB 39.1 shall be returned unopened to the Bidders.

39.3 No Bid may be withdrawn, substituted, or modified in the interval between the deadline for submission of Second-Stage Bids and the expiration of the period of bid validity specified by the Bidder on the Letter of Bid or any extension thereof.

40.1 The Employer shall open the Second-Stage bids in public at the address, on the date, and time specified in the Letter of Invitation to submit Second-Stage Bids in the presence of Bidders' designated representatives and anyone who choose to attend. Any specific electronic bid opening procedures required if electronic bidding is permitted in accordance with ITB 36.1 shall be as specified in the BDS. 
40.2 First, envelopes marked "SECOND-STAGE BID - WITHDRAWAL" shall be opened and read out and the envelope with the corresponding Bid shall not be opened, but returned to the Bidder. No bid withdrawal shall be permitted unless the corresponding withdrawal notice contains a valid authorization to request the withdrawal and is read out at bid opening. Next, envelopes marked "SECOND-STAGE BID - SUBSTITUTION" shall be opened and read out and exchanged with the corresponding Bid being substituted. The substituted Bid shall not be opened, but returned to the Bidder. No bid substitution shall be permitted unless the corresponding substitution notice contains a valid authorization to request the substitution and is read out at bid opening. Envelopes marked "SECOND-STAGE BID - MODIFICATION" shall be opened and read out with the corresponding Bid. No bid modification shall be permitted unless the corresponding modification notice contains a valid authorization to request the modification and is read out at bid opening. Only envelopes that are opened and read out at bid opening shall be considered further.

40.3 All other envelopes shall be opened one at a time, reading out the name of the Bidder and whether there is a modification; the Bid Price(s), including any discounts; the presence of a bid security, or a Bid-Securing Declaration, if required; and any other details as the Employer may consider appropriate. Only discounts read out at bid opening shall be considered for evaluation. Unless otherwise specified in the BDS, all pages of the Letter of Second-Stage Bid and Price Schedules are to be initialed by at least three representatives of the Employer attending the bid opening. No Bid shall be rejected at bid opening except for late bids, in accordance with ITB 38.1.

40.4 The Employer shall prepare a record of the Bid opening that shall include, as a minimum, the name of the Bidder and whether there is a withdrawal, substitution, or modification; the Bid Price, per lot if applicable, including any discounts; and the presence or absence of a bid security or a Bid-Securing Declaration, if one was required. The Bidders' representatives who are present shall be requested to sign the record. The omission of a Bidder's signature on the record shall not invalidate the contents and effect of the record. A copy of the record shall be distributed to all Bidders who submitted Bids on time, and posted online when electronic bidding is permitted.

\section{E-3. Second-Stage Bids - Evaluation and Comparison}

41. Clarification of Second-Stage Bids
41.1 To assist in the examination, evaluation, and comparison of the Second-Stage Bids, and qualification of the Bidders, the Employer may, at its discretion, ask any Bidder for a clarification of its bid. Any clarification submitted by a Bidder that is not in response to a request by the Employer shall not be considered. The Employer's request for clarification and the response shall be in writing. No change in the prices or substance of the bid shall be sought, offered, or permitted, except to confirm the correction of arithmetic errors discovered by the Employer in the evaluation of the Second-Stage Bids, in accordance with ITB 45.1.

41.2 If a Bidder does not provide clarifications of its bid by the date and time set in the Employer's request for clarification, its bid may be rejected. 
42. Deviations, Reservations, and Omissions

43. Determination of Responsiveness

44. Nonmaterial Nonconformities
42.1 During the evaluation of Second-Stage Bids, the following definitions apply:

(a) "Deviation" is a departure from the requirements specified in the Bidding Document;

(b) "Reservation" is the setting of limiting conditions or withholding from complete acceptance of the requirements specified in the Bidding Document; and

(c) "Omission" is the failure to submit part or all of the information or documentation required in the Bidding Document.

43.1 The Employer's determination of a Bid's responsiveness is to be based on the contents of the Bid itself, as defined in ITB 29.

43.2 A substantially responsive Bid is one that meets the requirements of the Bidding Document and has properly incorporated all modifications listed in the Memorandum entitled "Changes Required Pursuant to First-Stage Evaluation," without material deviation, reservation, or omission. A material deviation, reservation, or omission is one that

(a) if accepted, would

(i) affect in any substantial way the scope, quality, or performance of the plant and services specified in the Contract; or

(ii) limit in any substantial way, inconsistent with the Bidding Document, the Employer's rights, or the Bidder's obligations under the proposed Contract; or

(b) if rectified, would unfairly affect the competitive position of other Bidders presenting substantially responsive Bids.

43.3 If a Bid is not substantially responsive to the requirements of the Bidding Document, it shall be rejected by the Employer and may not subsequently be made responsive by correction of the material deviation, reservation, or omission.

44.1 Provided that a Bid is substantially responsive, the Employer may waive any nonconformities in the Bid that do not constitute a material deviation, reservation, or omission.

44.2 Provided that a Bid is substantially responsive, the Employer may request that the Bidder submit the necessary information or documentation, within a reasonable period of time, to rectify nonmaterial nonconformities in the Bid related to documentation requirements. Requesting information or documentation on such nonconformities shall not be related to any aspect of the price of the Bid. Failure of the Bidder to comply with the request may result in the rejection of its Bid. 
44.3 Provided that a Bid is substantially responsive, the Employer shall rectify quantifiable nonmaterial nonconformities related to the Bid Price. To this effect, the Bid Price shall be adjusted, for comparison purposes only, to reflect the price of a missing or nonconforming item or component. The adjustment shall be made using the method indicated in Section 3 (Evaluation and Qualification Criteria).

\section{Correction of Arithmetical Errors}

46. Conversion to Single Currency

\section{Domestic Preference}

45.1 Provided that the Bid is substantially responsive, the Employer shall correct arithmetical errors on the following basis:

(a) where there are errors between the total of the amounts given under the column for the price breakdown and the amount given under the Total Price, the total of the amounts given under the column for the price breakdown shall prevail and the amount given under the Total Price will be corrected accordingly;

(b) where there are errors between the total of the amounts of Schedule Nos. 1 to 4 and the amount given in Schedule No. 5 (Grand Summary), the total of the amounts of Schedule Nos. 1 to 4 shall prevail and the amount given in Schedule No. 5 (Grand Summary) will be corrected accordingly;

(c) if there is a discrepancy between the grand total price given in Schedule No. 5 (Grand Summary) and the bid amount in item (c) of the Letter of Second-Stage Bid, the grand total price given in Schedule No. 5 (Grand Summary) will prevail and the bid amount in item (c) of the Letter of Second-Stage Bid will be corrected; and

(d) if there is a discrepancy between words and figures, the amount in words shall prevail, unless the amount expressed in words is related to an arithmetic error, in which case the amount in figures shall prevail subject to (a), (b), and (c) above.

45.2 If the Bidder that submitted the lowest evaluated Bid does not accept the correction of errors, its Bid shall be disqualified and its bid security may be forfeited, or its Bid-Securing Declaration may be executed.

46.1 For evaluation and comparison purposes, the currency(ies) of the Bid shall be converted into a single currency as specified in the BDS.

47.1 Unless otherwise specified in the BDS, domestic preference shall not apply. 
48. Evaluation and Comparison of Second-Stage Bids
48.1 The Employer shall use the criteria and methodologies indicated in this Clause. No other evaluation criteria or methodologies shall be permitted.

\section{Technical Evaluation}

48.2 The Employer will carry out a detailed evaluation of the Second-Stage Bids to determine whether the technical aspects concerning the modifications to the technically acceptable base or alternative bid detailed in the Memorandum entitled "Changes Required Pursuant to First-Stage Evaluation", pursuant to ITB 28.1, have been properly addressed and are substantially responsive to the requirements set forth in the Bidding Document.

\section{Economic Evaluation}

48.3 I. To evaluate a bid, the Employer shall consider the following:

(a) the bid price, excluding provisional sums and the provision, if any, for contingencies in the Price Schedules;

(b) price adjustment for correction of arithmetical errors in accordance with ITB 45.1;

(c) price adjustment due to discounts offered in accordance with ITB 31.7;

(d) price adjustment due to quantifiable nonmaterial nonconformities in accordance with ITB 44.3;

(e) converting the amount resulting from applying (a) to (c) above, if relevant, to a single currency in accordance with ITB 46;

(f) assessment whether the bid is abnormally low in accordance with ITB 49; and

(g) the evaluation factors indicated in Section 3 (Evaluation and Qualification Criteria).

II. The Employer's evaluation of a bid will exclude and not take into account,

(a) in the case of Plant and Mandatory Spare Parts (Schedule No. 1) supplied from abroad, all taxes and duties, applicable in the Employer's country and payable on the Plant and Mandatory Spare Parts if the Contract is awarded to the Bidder; and

(b) in the case of Plant and Mandatory Spare Parts (Schedule No. 2) supplied from within the Employer's country, sales, and other taxes, applicable in the Employer's country and payable on the Plant and Mandatory Spare Parts if the Contract is awarded to the Bidder.

48.4 If price adjustment is allowed in accordance with ITB 31.6, the estimated effect of the price adjustment provisions of the Conditions of Contract, applied over the period of execution of the Contract, shall not be taken into account in bid evaluation. 
48.5 If this Bidding Document allows Bidders to quote separate prices for different lots (contracts), and the award to a single Bidder of multiple lots (contracts), the methodology to determine the lowest evaluated price of the lot (contract) combinations, including any discounts offered in the Letter of Second-Stage Bid, is specified in Section 3 (Evaluation and Qualification Criteria).

48.6 If the Bid, which results in the lowest Evaluated Bid Price, is seriously unbalanced or front loaded in the opinion of the Employer, the Employer may require the Bidder to produce detailed price analyses for any or all items of the Price Schedules, to demonstrate the internal consistency of those prices with the methods and time schedule proposed. After evaluation of the price analyses, taking into consideration the terms of payments, the Employer may require that the amount of the performance security be increased at the expense of the Bidder to a level sufficient to protect the Employer against financial loss in the event of default of the successful Bidder under the Contract.

48.7 The Employer shall compare all substantially responsive Second-Stage Bids to determine the lowest evaluated bid, in accordance with ITB 48.3.

49. Abnormally Low Second-Stage Bids
49.1 An abnormally low bid is one where the bid price, in combination with other elements of the bid, appears to be so low that it raises concerns as to the capability of the Bidder to perform the contract for the offered bid price.

49.2 When the offered bid price appears to be abnormally low, the Employer shall undertake a three-step review process as follows:

(a) identify abnormally low costs and unit rates by comparing them with the engineer's estimates, other substantially responsive bids, or recently awarded similar contracts;

(b) clarify and analyze the Bidder's resource inputs and pricing, including overheads, contingencies and profit margins; and

(c) decide whether to accept or reject the bid.

49.3 With regard to ITB 49.2 (b) above, the Employer will seek a written explanation from the bidder of the reasons for the offered bid price, including a detailed analysis of costs and unit prices, by reference to the scope, proposed methodology, schedule, and allocation of risks and responsibilities. This may also include information regarding the economy of the manufacturing process; the services to be provided, or the construction method to be used; the technical solutions to be adopted; and any exceptionally favorable conditions available to the bidder for the works, equipment or services proposed.

49.4 After examining the explanation given and the detailed price analyses presented by the bidder, the Employer may:

(a) accept the bid, if the evidence provided satisfactorily accounts for the low bid price and costs, in which case the bid is not considered abnormally low; 
(b) accept the bid, but require that the amount of the performance security be increased at the expense of the bidder to a level sufficient to protect the Employer against financial loss. The amount of the performance security shall generally be not more than $20 \%$ of the contract price; or

(c) reject the bid if the evidence provided does not satisfactorily account for the low bid price, and make a similar determination for the next ranked bid, if required.

\section{Qualification of} the Bidder
50.1 The Employer shall determine to its satisfaction whether the Bidder that is selected as having submitted the lowest evaluated and substantially responsive Second-Stage Bid still meets the qualifying criteria specified in Section 3 (Evaluation and Qualification Criteria).

50.2 An affirmative determination shall be a prerequisite for award of the Contract to the Bidder. The Employer reserves the right to reject the bid of any bidder found to be in circumstances described in GCC 42.2.1(a). A negative determination shall result in disqualification of the Bid, in which event the Employer shall proceed to the next lowest evaluated Bid to make a similar determination of that Bidder's qualifications to perform satisfactorily.

50.3 The participation of the manufacturers and Subcontractors proposed in its Bid for the major items of plant and services to be used by the lowest evaluated Bidder should be confirmed with a letter of intent between the parties, as needed. The capabilities of additional or different manufacturers and Subcontractors proposed in its Bid to be used by the lowest evaluated Bidder in compliance with the memorandum "Changes Required Pursuant to First-Stage Evaluation" will also be evaluated for acceptability in accordance with Section 3 (Evaluation and Qualification Criteria). Should any such additional or substitute manufacturer or Subcontractor as required by the memorandum "Changes Required Pursuant to First-Stage Evaluation" be determined to be unacceptable, the Bid will not be rejected, but the Bidder will be required to propose, without changing its bid price, an acceptable substitute manufacturer or Subcontractor meeting the minimum technical specifications stated in Section 6 (Employer's Requirements) within a reasonable period prior to contract award. Failure to provide an acceptable substitute by the date and time set in the Employer's request for substitution will lead to rejection of the Second-Stage Bid.

50.4 Prior to signing the Contract, the corresponding Appendix to the Contract Agreement shall be completed, listing the approved Manufacturers or Subcontractors for each item concerned.

51.1 The Employer reserves the right to accept or reject any bid, and to annul the bidding process and reject all Bids at any time prior to contract award, without thereby incurring any liability to Bidders. In case of annulment, all Bids submitted and specifically, bid securities, shall be promptly returned to the Bidders. 
52. Notice of Intention for Award of Contract

\section{F. Award of Contract}

53. Award Criteria

\section{Notification of Award}

52.1 If Standstill provisions apply as specified in the BDS, the standstill period shall be defined in the BDS to specify the duration subsequent to notification of intention for award of contract (before making the actual contract award) within which any unsuccessful bidder can challenge the proposed award.

53.1 The Employer shall award the Contract to the Bidder whose offer has been determined successful in line with ITB 48 and ITB 49 above to be the lowest evaluated Bid and is substantially responsive to the Bidding Document, provided further that the Bidder is determined to be eligible and qualified to perform the Contract satisfactorily.

54.1 Prior to the expiration of the period of bid validity and upon expiry of the standstill period specified in ITB 52.1, or upon satisfactory resolution of a complaint filed within standstill period, if applicable, the Employer shall transmit the Notification of Award through issuance of Letter of Acceptance using the form included in Section 9 (Contract Forms) to the successful Bidder, in writing, that its Bid has been accepted. At the same time, the Employer shall also notify all other Bidders of the results of the bidding.

54.2 Unless standstill period applies, upon notification of award through issuance of Letter of Acceptance, unsuccessful Bidders may request in writing to the Employer for a debriefing seeking explanations on the grounds on which their Bids were not selected. The Employer shall promptly respond in writing and/or in a debriefing meeting to any unsuccessful Bidder who, after publication of contract award, requests a debriefing.

54.3 Until a formal contract is prepared and executed, the notification of award through issuance of Letter of Acceptance shall constitute a binding Contract.

54.4 Within 2 weeks of the award of contract or expiry of the standstill period, where such period applies, or, if a complaint has been filed within the standstill period, upon receipt of ADB's confirmation of satisfactory resolution of the complaint, the borrower shall publish in an English language newspaper or widely known and freely accessible website the results identifying the bid and lot or package numbers, as applicable and the following information:

(a) name of each Bidder who submitted a Bid;

(b) bid prices as read out at bid opening;

(c) name and evaluated prices of each Bid that was evaluated;

(d) name of Bidders whose Bids were rejected and the reasons for their rejection; and

(e) name of the winning Bidder, and the price it offered, as well as the duration and summary scope of the contract awarded. 
55. Signing of Contract

56. Performance Security

57. Bidding-Related Complaints
55.1 Promptly after notification, the Employer shall send the successful Bidder the Contract Agreement.

55.2 Within 28 days of receipt of the Contract Agreement, the successful Bidder shall sign, date, and return it to the Employer.

56.1 Within 28 days of the receipt of notification of award through issuance of Letter of Acceptance from the Employer, the successful Bidder shall furnish the performance security in accordance with the Conditions of Contract, subject to ITB 48.6 and ITB 49.4, using for that purpose the Performance Security Form included in Section 9 (Contract Forms), or another form acceptable to the Employer. If the bank issuing performance security is located outside the Employer's country, it shall be counter-guaranteed or encashable by a bank in the Employer's country.

56.2 Failure of the successful Bidder to submit the abovementioned performance security or sign the Contract shall constitute sufficient grounds for the annulment of the award and forfeiture of the bid security or execution of the Bid-Securing Declaration. In that event, the Employer may award the Contract to the next lowest evaluated Bidder whose offer is substantially responsive and is determined by the Employer to be qualified to perform the Contract satisfactorily.

57.1 The procedures for dealing with Bidding-Related Complaints arising out of this bidding process are specified in the BDS. 


\section{Section 2: Bid Data Sheet}

This Section contains the provisions that apply to specific types of procurement and supplement the information or requirements in Section 1 (Instructions to Bidders).

\section{A. General}

\begin{tabular}{|l|l|}
\hline ITB 1.1 & $\begin{array}{l}\text { The number of the Invitation for Bids (IFB) is: [insert identification number of the IFB] } \\
\text { The Employer is: [insert name of the Employer] } \\
\text { The name of the open competitive bidding (OCB) is: [insert the name of OCB] } \\
\text { The identification number of the OCB is: [insert identification number of the OCB] } \\
\text { The number and identification of lots (contracts) comprising this OCB is: } \\
{\left[\begin{array}{l}\text { if there are no lots, insert "None," If there are lots, insert a list of lots, identifying each lot by indicating number } \\
\text { and name of lots or contracts] }\end{array}\right.}\end{array}$ \\
\hline ITB 2.1 & $\begin{array}{l}\text { The Borrower is: [insert name of the borrower] } \\
\text { The name of the Project is: [insert name of the project] }\end{array}$ \\
\hline
\end{tabular}

\section{B. Contents of Bidding Document}

\begin{tabular}{|l|l}
\hline ITB 7.1 & $\begin{array}{l}\text { For clarification purposes only, the Employer's address is: } \\
\text { [insert details below as appropriate] } \\
\text { Attention: [insert full name of the person, if applicable] } \\
\text { Street address: [insert street address and number] } \\
\text { Floor/Room number: [insert floor and room number, if applicable] } \\
\text { City: [insert name of the city or town] } \\
\text { ZIP code: [insert postal (ZIP) code, if applicable] } \\
\text { Country: [insert name of country] } \\
\text { Telephone: [insert telephone number, including country and city codes] } \\
\text { Fax: [insert fax number, with country and city codes] } \\
\text { E-mail: [insert e-mail address, if applicable] }\end{array}$
\end{tabular}


ITB 7.4

A Pre-Bid meeting [insert "will" or "will not"] take place.

[If a pre-bid meeting takes place, insert date, time, and place below]

Date:

Time:

Place:

A site visit conducted by the Employer [insert "will" or "will not"] be organized.

\section{C-1. First-Stage Bids - Preparation}

\begin{tabular}{|l|l|}
\hline ITB 10.1 & The language of the Bid is: [insert "English"] \\
\hline ITB 11.1(i) & $\begin{array}{l}\text { The Bidder shall submit with its bid the following additional documents: } \\
\text { [insert a list of additional documents if so required] }\end{array}$ \\
\hline ITB 16.1(b) & $\begin{array}{l}\text { The period following completion of plant and services in accordance with provisions of the } \\
\text { contract shall be [insert number of years as appropriate] }\end{array}$ \\
\hline ITB 18.1 & \begin{tabular}{l} 
In addition to the original bid, the number of copies is: [insert number of copies] \\
\hline ITB 18.2
\end{tabular}$\quad \begin{array}{l}\text { The written confirmation of authorization to sign on behalf of the Bidder shall consist of: } \\
\text { [insert the name and description of the documentation required to demonstrate the authority of the signatory } \\
\text { to sign the bid. The Employer may wish to consider the following language: "An organizational document, board } \\
\text { resolution or its equivalent, or power of attorney specifying the representative's authority to sign the Bid on behalf } \\
\text { of, and to legally bind, the Bidder. If the Bidder is an intended or an existing Joint Venture, the power of attorney } \\
\text { should be signed by all partners and specify the authority of the named representative of the Joint Venture to sign } \\
\text { on behalf of, and legally bind, the intended or existing Joint Venture. If the Joint Venture has not yet been formed, } \\
\text { also include evidence from all proposed Joint Venture partners of their intent to enter into a Joint Venture in the } \\
\text { event of a contract award in accordance with ITB 11.2."] }\end{array}$ \\
\hline $\begin{array}{l}\text { The Bidder shall submit an acceptable authorization within [insert number of days, generally 14 days] } \\
\text { days. }\end{array}$ \\
\hline
\end{tabular}

\section{C-2. First-Stage Bids - Submission and Opening}

\begin{tabular}{|l|l|}
\hline ITB 19.1 & $\begin{array}{l}\text { [Choose one of the following options as appropriate.] } \\
\text { Bidders shall submit their Bids by mail or by hand. } \\
{[\text { or }]} \\
\text { Bidders shall submit their Bids electronically. }\end{array}$ \\
\hline ITB 19.1(b) & $\begin{array}{l}\text { Electronic bidding submission procedures shall be: [insert a description of the electronic bidding } \\
\text { submission procedures if applied in accordance with ITB 19.1 above; otherwise, state "not applicable"] }\end{array}$ \\
\hline
\end{tabular}




\begin{tabular}{|c|c|}
\hline ITB 20.1 & $\begin{array}{l}\text { For First-Stage Bid submission purposes only, the Employer's address is } \\
\text { [insert details below as appropriate] } \\
\text { Attention: } \\
\text { Street address: } \\
\text { Floor/Room number: } \\
\text { City: } \\
\text { ZIP code: } \\
\text { Country: } \\
\text { The deadline for First-Stage Bid submission is } \\
\text { Date: } \\
\text { Time: }\end{array}$ \\
\hline ITB 22.1 & $\begin{array}{l}\text { The bid opening shall take place at } \\
\text { [insert details below as appropriate] } \\
\text { Street address: } \\
\text { Floor/Room number: } \\
\text { City: } \\
\text { Country: } \\
\text { Date: } \\
\text { Time: }\end{array}$ \\
\hline ITB 22.1 & $\begin{array}{l}\text { Electronic bid opening procedure shall be as follows: [if electronic bidding is permitted in accordance } \\
\text { with ITB 19.1, insert here a description of the electronic bid opening procedures; otherwise, state "Not applicable"] }\end{array}$ \\
\hline
\end{tabular}




\section{C-3. First-Stage Bids - Evaluation}

ITB 26.2

[Choose one of the following options as appropriate.]

The qualifications of other firms such as the Bidder's subsidiaries, parent entities, or affiliates shall not be permitted.

[or]

The qualifications of other firms such as the Bidder's subsidiaries, parent entities, or affiliates shall be permitted for criteria 2.3 Financial Situation in Section 3. The other firms must satisfy the criteria stated in 2.1 Eligibility in Section 3.

$[o r]$

The qualifications of other firms such as the Bidder's subsidiaries, parent entities, or affiliates shall be permitted for criterion 2.4.1 Contracts of Similar Size and Nature and/or 2.4.2

Experience in Key Activities in Section 3. The other firms must satisfy the criteria stated in 2.1 Eligibility in Section 3.

[or]

The qualifications of other firms such as the Bidder's subsidiaries, parent entities, or affiliates shall be permitted for criteria 2.3 Financial Situation and 2.4.1 Contracts of Similar Size and Nature and/or 2.4.2 Experience in Key Activities in Section 3. The other firms must satisfy the criteria stated in 2.1 Eligibility in Section 3.

[If permitted, add"The Bidder shall provide the Affiliate Company Guarantee Form included in Section 4 (Bidding Forms) filled out and signed by each subsidiary, parent entity, or affiliate that the Bidder submits for consideration of the Employer in determining its qualifications."]

\section{E-1. Second Stage - Bid Preparation}

\begin{tabular}{|l|l|}
\hline ITB 29.1(j) & $\begin{array}{l}\text { The Bidder shall submit with its Second-Stage Bid the following additional documents: } \\
{[\text { insert a list of additional documents if so require }]}\end{array}$ \\
\hline ITB 30.1 & $\begin{array}{l}\text { The units and rates in figures entered into the Price Schedules should be typewritten; if written } \\
\text { by hand, must be in print form. Price Schedules not presented accordingly may be considered } \\
\text { nonresponsive. }\end{array}$ \\
\hline ITB 31.1 & $\begin{array}{l}{[\text { Choose one of the following options as appropriate }]} \\
\text { Bidders shall quote for the entire plant and services on a single responsibility basis. } \\
{[\text { or }]} \\
\text { Bidders shall quote for the following components or services on a single responsibility basis: } \\
{[\text { insert list of components or services }]} \\
{[\text { and/or }]} \\
\text { The following components or services will be provided under the responsibility of the Employer: } \\
{[\text { insert list of components or services }]}\end{array}$ \\
\hline ITB 31.4(a)(i) & \begin{tabular}{l} 
The Incoterm for quoting plant to be supplied from abroad is: [insert CIP-named place of destination $]$ \\
\hline
\end{tabular}
\end{tabular}




\begin{tabular}{|c|c|}
\hline ITB 31.6 & $\begin{array}{l}\text { The prices quoted by the Bidder shall be [insert "fixed" or "adjustable"] } \\
\text { [If prices are to be adjustable, insert: "The formula for adjusting the prices and explanatory details are specified in } \\
\text { the SCC Clause } 11.2 \text { and Appendix } 2 \text { of Contract Agreement. Bidder shall fill out the Tables of Adjustment Data in } \\
\text { Section } 4 \text { (Bidding Forms)."] } \\
\text { [Use "Adjustable" where the contract period is of long duration (generally exceeds } 18 \text { months). Prices payable to the } \\
\text { Contractor shall be subject to price adjustment during the performance of the Contract."] } \\
\text { [If prices shall be fixed, the Tables of Adjustment Data in Section } 4 \text { (Bidding Forms) shall be removed."] }\end{array}$ \\
\hline ITB 32.1 & $\begin{array}{l}\text { The currency of the bid shall be as follows: } \\
\text { (a) The prices shall be quoted either in the currency of the Bidder's home country, or any fully } \\
\text { convertible currency(ies). } \\
\text { (b) A Bidder expecting to incur a portion of its expenditures in the performance of the Contract in } \\
\text { more than one currency, and wishing to be paid accordingly, shall so indicate in the Schedule } \\
\text { of Prices and the Letter of Second-Stage Bid. } \\
\text { (c) If some of the contract expenditures related to Design, Installation, and Other Services are to } \\
\text { be incurred in the Employer's country, such expenditures shall be quoted in either foreign and/ } \\
\text { or local currency, depending upon the currency in which the costs are to be incurred. } \\
\text { (d) Bidders may be required by the Employer to clarify their local and foreign currency } \\
\text { requirements, and to substantiate that the amounts included in the Price Schedules are } \\
\text { reasonable and responsive to ITB } 31.1 \text { in which case a detailed breakdown of its foreign } \\
\text { currency requirements shall be provided by the Bidder. } \\
\text { (e) During the performance of the contract, the foreign currency portions of the outstanding } \\
\text { balance of the Contract Price may be adjusted by agreement between the Employer and the } \\
\text { Contractor to reflect any changes in foreign currency requirements for the contract. Any such } \\
\text { adjustment shall be effected by comparing the amounts quoted in the Bid with the amounts } \\
\text { already used in the Facilities and the Contractor's future needs for imported items. }\end{array}$ \\
\hline ITB 33.1 & $\begin{array}{l}\text { The bid validity period shall be [insert number of days] days. } \\
\text { [The period should be sufficient to permit completion of evaluation and comparison of bids, review of the } \\
\text { recommended selection by ADB (if so required), acquire all necessary approvals, and notify the successful bidder of } \\
\text { the award. Normally, the bid validity period should not exceed } 120 \text { days.] }\end{array}$ \\
\hline ITB 34.1 & $\begin{array}{l}\text { [Choose one of the following options as appropriate] } \\
\text { Neither a bid security nor a Bid-Securing Declaration is required. } \\
\text { [or] } \\
\text { The Bidder shall furnish a bid security in the amount of } \\
\text { [insert amount and currency. The amount of the bid security should be stated as a fixed amount, normally } \\
\text { computed as } 1 \% \text { to } 2 \% \text { of the estimated contract value. The amount may be reduced for very large contracts] } \\
\text { [or] } \\
\text { The Bidder shall furnish a Bid-Securing Declaration. }\end{array}$ \\
\hline ITB 34.2 & ligibility period will be [insert number of years] \\
\hline
\end{tabular}




\begin{tabular}{|c|c|}
\hline ITB 34.4 & $\begin{array}{l}\text { [Choose one of the following options as appropriate.] } \\
\text { No further instruction. } \\
\text { [or] } \\
\text { Subject to the succeeding sentences, any bid not accompanied by an irrevocable and callable } \\
\text { bid security shall be rejected by the Employer as nonresponsive. If a Bidder submits a bid } \\
\text { security that (i) deviates in form, amount, and/or period of validity, or (ii) does not provide } \\
\text { sufficient identification of the Bidder (including, without limitation, failure to indicate the name } \\
\text { of the Joint Venture or, where the Joint Venture has not yet been constituted, the names of all } \\
\text { future Joint Venture Partners), the Employer shall request the Bidder to submit a compliant bid } \\
\text { security within [insert number of days; generally } 14 \text { days] days of receiving such a request. Failure to } \\
\text { provide a compliant bid security within the prescribed period of receiving such a request shall } \\
\text { cause the rejection of the Bid. } \\
\text { [or] } \\
\text { Subject to the succeeding sentences, any bid not accompanied by Bid-Securing } \\
\text { Declaration shall be rejected by the Employer as nonresponsive. If a Bidder submits a } \\
\text { Bid-Securing Declaration that (i) deviates in form, content , and/or period of validity or } \\
\text { (ii) does not provide sufficient identification of the Bidder (including, without limitation, } \\
\text { failure to indicate the name of the Joint Venture or, where the Joint Venture has not yet } \\
\text { been constituted, the names of all future Joint Venture Partners), the Employer shall } \\
\text { request the Bidder to submit a compliant Bid-Securing Declaration within [insert number } \\
\text { of days; generally } 7 \text { days] days of receiving such a request. Failure to provide a compliant } \\
\text { Bid-Securing Declaration within the prescribed period of receiving such a request shall } \\
\text { cause the rejection of the Bid. }\end{array}$ \\
\hline ITB 35.1 & In addition to the original Bid, the number of copies is: [insert number of copies] \\
\hline ITB 35.2 & $\begin{array}{l}\text { The written confirmation of authorization to sign on behalf of the Bidder shall consist of } \\
\text { [insert the name and description of the documentation required to demonstrate the authority of the signatory } \\
\text { to sign the bid. Employer may wish to consider the following language: "An organizational document, board } \\
\text { resolution, or its equivalent, or power of attorney specifying the representative's authority to sign the bid on behalf } \\
\text { of, and to legally bind, the bidder. If the bidder is an intended or an existing Joint Venture, the power of attorney } \\
\text { should be signed by all partners and specify the authority of the named representative of the Joint Venture to sign on } \\
\text { behalf of, and legally bind, the intended or existing Joint Venture. If the Joint Venture has not yet been formed, also } \\
\text { include evidence from all proposed Joint Venture partners of their intent to enter into a Joint Venture in the event of } \\
\text { a contract award in accordance with ITB 11.2."] }\end{array}$ \\
\hline ITB 35.2 & bmit an acceptable authorization within [insert number of days, generally 14 days] days. \\
\hline
\end{tabular}

\section{E-2. Second-Stage Bids - Submission and Opening}

\begin{tabular}{|l|l|}
\hline ITB 36.1 & $\begin{array}{l}\text { [Choose one of the following options as appropriate. }] \\
\text { Bidders shall submit their Bids by mail or by hand. } \\
{[\text { or }]} \\
\text { Bidders shall submit their Bids electronically. }\end{array}$ \\
\hline ITB 36.1(b) & $\begin{array}{l}\text { Electronic bidding submission procedures shall be: [insert a description of the electronic bidding } \\
\text { submission procedures if applied in accordance with ITB 36.1 above; otherwise, state "not applicable"] }\end{array}$ \\
\hline
\end{tabular}




\begin{tabular}{|l|l|}
\hline ITB 40.1 & $\begin{array}{l}\text { Electronic bid opening procedure shall be as follows: [if electronic bidding is permitted in accordance with } \\
\text { ITB 36.1, insert here a description of the electronic bid opening procedures; otherwise, state "not applicable"] }\end{array}$ \\
\hline ITB 40.3 & $\begin{array}{l}\text { The Letter of Second-Stage Bid and Price Schedules shall be initialed by [insert number of initials] } \\
\text { representatives of the Employer attending the Bid opening. }\end{array}$ \\
\hline
\end{tabular}

\section{E-3. Second-Stage Bids - Evaluation and Comparison}

\begin{tabular}{|c|c|}
\hline ITB 46.1 & $\begin{array}{l}\text { The currency that shall be used for bid evaluation and comparison purposes to convert all bid } \\
\text { prices expressed in various currencies into a single currency is: [insert name of currency] } \\
\text { The source of selling exchange rate shall be: [insert the name of the source of the exchange rates, which } \\
\text { should be the Central Bank in the employer's country or specify another institution that carries out the function } \\
\text { of a central bank] } \\
\text { The date for the selling exchange rate shall be: [specify either any date (day/month/year) not earlier } \\
\text { than } 28 \text { days prior to the deadline for submission of the bids or later than the original date for the expiry } \\
\text { of bid validity] }\end{array}$ \\
\hline ITB 47.1 & $\begin{array}{l}\text { Domestic preference [insert "shall" or "shall not"] apply. } \\
\text { [If domestic preference applies, insert "The application methodology will be as specified in Section } 3 \\
\text { (Evaluation and Qualification Criteria)."] }\end{array}$ \\
\hline ITB 52.1 & $\begin{array}{l}\text { [Choose one of the following options as appropriate.] } \\
\text { Standstill provisions shall not apply. } \\
\text { [or] } \\
\text { Standstill provisions shall apply. The duration of standstill period will be [insert number of days] days } \\
\text { from the date of notice of intention for award of contract. } \\
\text { The Employer shall, at the start of the standstill period, notify in writing each bidder that } \\
\text { submitted a bid, of its intention to award a contract to the successful bidder at the end of standstill } \\
\text { period. The notification using the form included in Section } 9 \text { (Contract Forms) shall include the } \\
\text { following information: } \\
\text { (a) the name of each Bidder who submitted a Bid; } \\
\text { (b) the bid prices as read out at bid opening; } \\
\text { (c) the name and evaluated prices of each Bid that was evaluated; } \\
\text { (d) the name of bidders whose bids were rejected and the reasons for their rejection; } \\
\text { (e) the name of the winning Bidder, and the price it offered, as well as the duration and summary } \\
\text { scope of the contract awarded; and } \\
\text { (f) a statement of the reason(s) the bid of the unsuccessful bidder to whom the notification is } \\
\text { addressed was unsuccessful, unless the price information under (e) of this paragraph already } \\
\text { reveals the reason. }\end{array}$ \\
\hline
\end{tabular}




\section{F. Award of Contract}

\begin{tabular}{l|l} 
ITB 57.1 The procedures for Bidding-Related Complaints are referenced in Appendix 7 of the
\end{tabular} Procurement Regulations for ADB Borrowers. The Bidder should submit its complaint following these procedures, in writing, to:

For the attention: [insert full name of person receiving complaints]

Title/position: [insert title/position]

Employer: [insert name of Employer]

E-mail address: [insert e-mail address]

Fax number: [insert fax number] delete if not used] 


\section{Section 3: Evaluation and Qualification Criteria}

\section{NOTES}

This section contains the criteria that the Employer shall use to evaluate bids and qualify Bidders if the bidding was not preceded by a prequalification exercise and postqualification is applied. ADB requires Bidders to be qualified by meeting predefined, precise minimum requirements. The method entails setting pass-fail criteria, which, if not met by the Bidder, results in disqualification. It will therefore be necessary to ensure that a Bidder's risk of having its bid rejected on grounds of qualification is remote if due diligence is exercised by the Bidder during bid preparation. For that purpose, clear-cut, pass-fail qualification criteria need to be defined and indicated in the Invitation for Bids and the Bidding Document to enable Bidders to make an informed decision whether to pursue a specific contract and, if so, whether to pursue it as a single entity or in Joint Venture. The criteria adopted must relate to characteristics that are essential to ensure satisfactory execution of the contract, and must be stated in clear terms. In accordance with ITB 25, ITB 26, ITB 48, and ITB 50, no other methods, criteria, and factors shall be used. The Bidder shall provide all the information requested in the forms included in Section 4 (Bidding Forms).

In case the bidding was preceded by a prequalification process, updating of information pertaining to a Bidder's eligibility, historical contract nonperformance, and financial situation will be necessary during bidding.

\section{Table of Criteria}

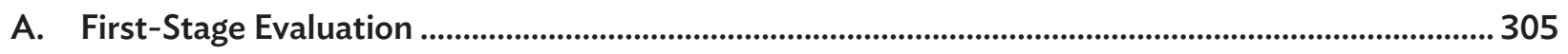

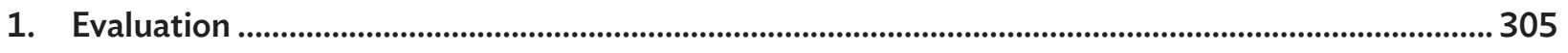

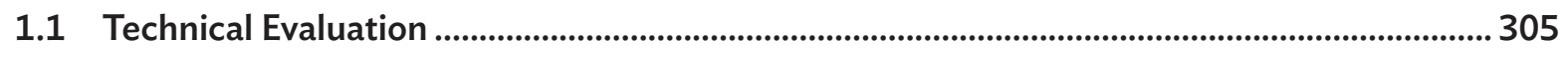

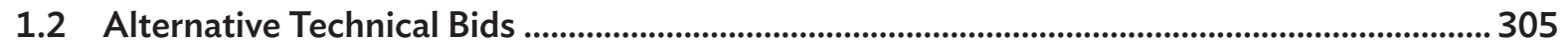

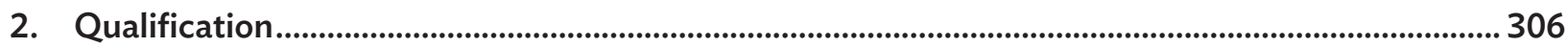

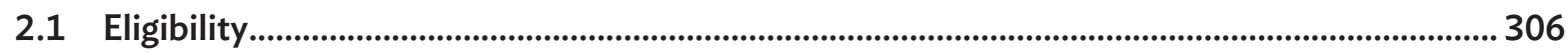

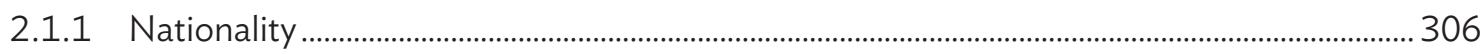

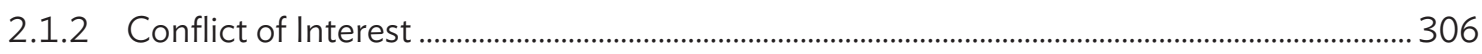

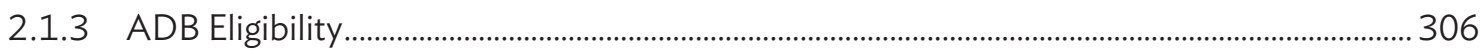

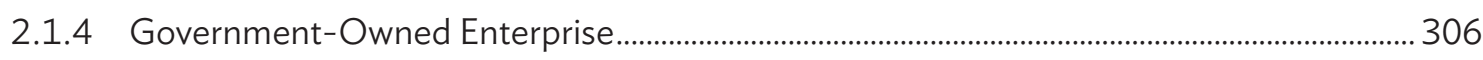

2.1.5 United Nations Eligibility ............................................................................................................... 307

2.2 Historical Contract Nonperformance................................................................................................. 308

2.2.1 History of Nonperforming Contracts ................................................................................................. 308

2.2.2 Suspension Based on Execution of Bid-Securing Declaration ................................................. 308

2.2.3 Pending Litigation and Arbitration ................................................................................................ 309

2.2.4 Declaration: Environmental, Health and Safety Past Performance ........................................309 


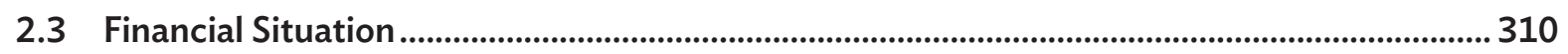

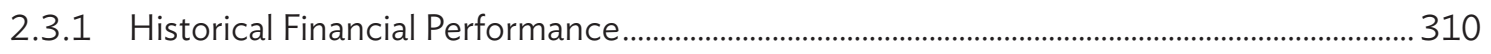

2.3.2 Average Annual Turnover ......................................................................................................... 311

2.3.3 Financial Resources.............................................................................................................................. 312

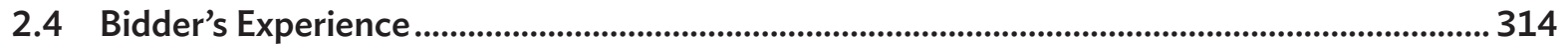

2.4.1 Contracts of Similar Size and Nature ............................................................................................ 314

2.4.2 Experience in Key Activities............................................................................................................. 316

2.4.3 Specific Experience in Managing Environmental, Health and Safety Aspects................... 317

2.5 Organizational Environmental, Health and Safety System ............................................................318

2.5.1 Environmental, Health and Safety Certification ..........................................................................318

2.5.2 Environmental, Health and Safety Documentation ................................................................319

2.5.3 Environmental, Health and Safety Dedicated Personnel .........................................................319

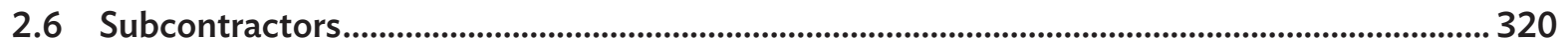

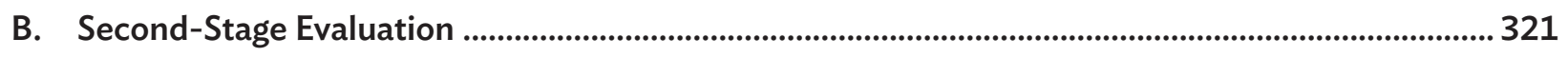

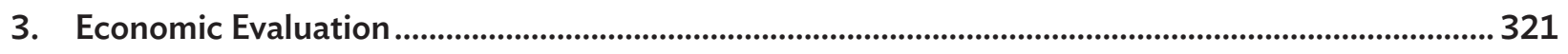

3.1 Quantifiable Deviations and Omissions.......................................................................................... 321

3.2 Operation and Maintenance Costs .................................................................................................. 321

3.3 Functional Guarantees of the Facilities ........................................................................................ 322

3.4 Work, Services, Facilities, etc., to Be Provided by the Employer................................................ 322

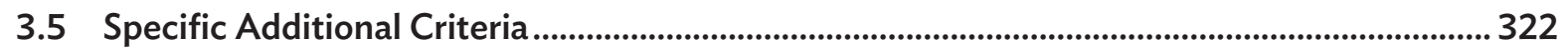

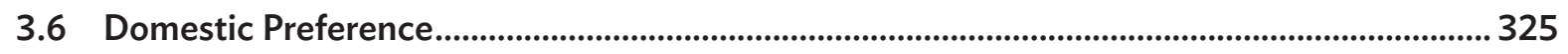

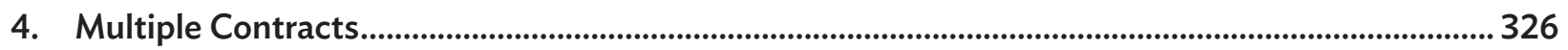




\section{A. First-Stage Evaluation}

\section{Evaluation}

\subsection{Technical Evaluation}

In addition to the criteria listed in ITB 25.1(a)-(c) other relevant factors are as follows:

Evaluation of the Bidder's Technical Proposal will include an assessment of the Bidder's technical capacity to successfully implement the contract considering its proposed site organization, method statement, mobilization, and construction schedule (to be described by the Bidder in sufficient detail to demonstrate the adequacy of its work methods, scheduling, and material sourcing) including the extent to which they are presented in a consistent manner and comply with requirements stipulated in Section 6 (Employer's Requirements) without material deviation, reservation, or omission.

Noncompliance with equipment and personnel requirements described in Section 6 (Employer's Requirements) shall not normally be a ground for bid rejection and such noncompliance will be subject to clarification during bid evaluation and rectification prior to contract award.

\section{NOTE}

The Employer shall refer to the appropriate forms in Section 4 to be filled out, if provided. The Employer shall assess whether proposed site organization, method statement, mobilization, construction schedule, plant, proposed Subcontractors for major items of plant and services, and time schedule described in Section 4 (Bidding Forms) are presented in consistent manner and comply with requirements stipulated in Section 6 (Employer's Requirements) without material deviation, reservation, or omission.

\subsection{Alternative Technical Bids}

Technical alternatives, if permitted under ITB 13, will be evaluated as follows: 


\section{Qualification}

\subsection{Eligibility}

\begin{tabular}{|c|c|c|c|c|c|}
\hline Criteria & \multicolumn{4}{|c|}{ Compliance Requirements } & Documents \\
\hline & & \multicolumn{3}{|c|}{ Joint Venture } & \\
\hline Requirement & Single Entity & $\begin{array}{l}\text { All Partners } \\
\text { Combined }\end{array}$ & $\begin{array}{l}\text { Each } \\
\text { Partner }\end{array}$ & $\begin{array}{l}\text { One } \\
\text { Partner }\end{array}$ & $\begin{array}{l}\text { Submission } \\
\text { Requirements }\end{array}$ \\
\hline
\end{tabular}

\subsubsection{Nationality}

\begin{tabular}{|l|c|c|c|c|c|}
\hline $\begin{array}{l}\text { Nationality in accordance with ITB } \\
\text { 4.2. }\end{array}$ & $\begin{array}{c}\text { Must meet } \\
\text { requirement }\end{array}$ & $\begin{array}{c}\text { Must meet } \\
\text { requirement }\end{array}$ & $\begin{array}{c}\text { Must meet } \\
\text { requirement }\end{array}$ & $\begin{array}{c}\text { Not } \\
\text { applicable }\end{array}$ & $\begin{array}{c}\text { Forms ELI - 1; } \\
\text { ELI - 2 with } \\
\text { attachments }\end{array}$ \\
\hline
\end{tabular}

\subsubsection{Conflict of Interest}

\begin{tabular}{|l|c|c|c|c|c|}
\hline $\begin{array}{l}\text { No conflicts of interest in accordance } \\
\text { with ITB 4.3. }\end{array}$ & $\begin{array}{c}\text { Must meet } \\
\text { requirement }\end{array}$ & $\begin{array}{c}\text { Must meet } \\
\text { requirement }\end{array}$ & $\begin{array}{c}\text { Must meet } \\
\text { requirement }\end{array}$ & $\begin{array}{c}\text { Not } \\
\text { applicable }\end{array}$ & $\begin{array}{c}\text { Letter of } \\
\text { First-Stage Bid }\end{array}$ \\
\hline
\end{tabular}

\subsubsection{ADB Eligibility}

\begin{tabular}{|l|c|c|c|c|c|}
\hline $\begin{array}{l}\text { Not having been declared ineligible } \\
\text { by ADB, as described in ITB 4.4. }\end{array}$ & $\begin{array}{c}\text { Must meet } \\
\text { requirement }\end{array}$ & $\begin{array}{c}\text { Must meet } \\
\text { requirement }\end{array}$ & $\begin{array}{c}\text { Must meet } \\
\text { requirement }\end{array}$ & $\begin{array}{c}\text { Not } \\
\text { applicable }\end{array}$ & $\begin{array}{c}\text { Letter of } \\
\text { First-Stage Bid }\end{array}$ \\
\hline
\end{tabular}

\subsubsection{Government-Owned Enterprise}

\begin{tabular}{|l|c|c|c|c|c|}
\hline $\begin{array}{l}\text { Bidder required to meet conditions of } \\
\text { ITB 4.5. }\end{array}$ & $\begin{array}{c}\text { Must meet } \\
\text { requirement }\end{array}$ & $\begin{array}{c}\text { Must meet } \\
\text { requirement }\end{array}$ & $\begin{array}{c}\text { Must meet } \\
\text { requirement }\end{array}$ & $\begin{array}{c}\text { Not } \\
\text { applicable }\end{array}$ & $\begin{array}{c}\text { Forms ELI - 1; } \\
\text { ELI - 2 with } \\
\text { attachments }\end{array}$ \\
\hline
\end{tabular}




\subsubsection{United Nations Eligibility}

\begin{tabular}{|l|c|c|c|c|c|}
\hline $\begin{array}{l}\text { Not having been excluded by an } \\
\text { act of compliance with a United } \\
\text { Nations Security Council resolution in } \\
\text { accordance with ITB 4.8. }\end{array}$ & $\begin{array}{c}\text { Must meet } \\
\text { requirement }\end{array}$ & $\begin{array}{c}\text { Must meet } \\
\text { requirement }\end{array}$ & $\begin{array}{c}\text { Must meet } \\
\text { requirement }\end{array}$ & $\begin{array}{c}\text { Not } \\
\text { applicable }\end{array}$ & $\begin{array}{c}\text { Letter of } \\
\text { First-Stage Bid }\end{array}$ \\
\hline
\end{tabular}

\section{NOTE}

It is the obligation of the Employer to confirm an entity's eligibility by checking ADB's complete Sanctions List (for all bidders) at various stages of bidding process including bid evaluation, prior to contract award, as well as during processing of contract variations, extensions or modifications. ADB has the right to monitor the Employer's compliance to this obligation.

ADB's complete Sanctions List and the guide on how to get its access are available at https://www.adb.org/who-we-are/ integrity/sanctions 


\subsection{Historical Contract Nonperformance}

\subsubsection{History of Nonperforming Contracts}

\begin{tabular}{|c|c|c|c|c|c|}
\hline Criteria & \multicolumn{4}{|c|}{ Compliance Requirements } & Documents \\
\hline \multirow[b]{2}{*}{ Requirement } & \multirow[b]{2}{*}{ Single Entity } & \multicolumn{3}{|c|}{ Joint Venture } & \multirow[b]{2}{*}{$\begin{array}{l}\text { Submission } \\
\text { Requirements }\end{array}$} \\
\hline & & $\begin{array}{l}\text { All Partners } \\
\text { Combined }\end{array}$ & $\begin{array}{c}\text { Each } \\
\text { Partner }\end{array}$ & $\begin{array}{c}\text { One } \\
\text { Partner }\end{array}$ & \\
\hline $\begin{array}{l}\text { Nonperformance of a contract }{ }^{a} \\
\text { did not occur as a result of } \\
\text { contractor default since } 1 \text { January } \\
\text { [insert year]. }\end{array}$ & $\begin{array}{l}\text { Must meet } \\
\text { requirement }\end{array}$ & $\begin{array}{c}\text { Must meet } \\
\text { requirement }\end{array}$ & $\begin{array}{c}\text { Must meet } \\
\text { requirement }^{\mathrm{b}}\end{array}$ & $\begin{array}{c}\text { Not } \\
\text { applicable }\end{array}$ & Form CON-1 \\
\hline
\end{tabular}

a Nonperformance, as decided by the Employer, shall include all contracts where (a) nonperformance was not challenged by the contractor, including through referral to the dispute resolution mechanism under the respective contract, and (b) contracts that were so challenged but fully settled against the contractor. Nonperformance shall not include contracts where Employers decision was overruled by the dispute resolution mechanism. Nonperformance must be based on all information on fully settled disputes or litigation, i.e. dispute or litigation that has been resolved in accordance with the dispute resolution mechanism under the respective contract and where all appeal instances available to the Bidder have been exhausted.

b This requirement also applies to contracts executed by the Bidder as Joint Venture partner.

\subsubsection{Suspension Based on Execution of Bid-Securing Declaration}

\begin{tabular}{|c|c|c|c|c|c|}
\hline \multirow{2}{*}{ Criteria } & \multicolumn{3}{|c|}{ Compliance Requirements } & \multirow{2}{*}{ Documents } \\
\cline { 3 - 4 } \multicolumn{1}{c|}{ Requirement } & Single Entity & $\begin{array}{c}\text { All Partners } \\
\text { Combined }\end{array}$ & $\begin{array}{c}\text { Each } \\
\text { Partner }\end{array}$ & $\begin{array}{c}\text { One } \\
\text { Partner }\end{array}$ & $\begin{array}{c}\text { Submission } \\
\text { Requirements }\end{array}$ \\
\cline { 2 - 5 } $\begin{array}{l}\text { Not under suspension based } \\
\text { on execution of a Bid-Securing } \\
\text { Declaration pursuant to ITB 4.6. }\end{array}$ & $\begin{array}{c}\text { Must meet } \\
\text { requirement }\end{array}$ & $\begin{array}{c}\text { Must meet } \\
\text { requirement }\end{array}$ & $\begin{array}{c}\text { Must meet } \\
\text { requirement }\end{array}$ & $\begin{array}{c}\text { Not } \\
\text { applicable }\end{array}$ & $\begin{array}{c}\text { Letter of } \\
\text { First-Stage Bid }\end{array}$ \\
\hline
\end{tabular}




\subsubsection{Pending Litigation and Arbitration}

Pending litigation and arbitration criterion [shall/shall not] apply. ${ }^{a}$

\begin{tabular}{|c|c|c|c|c|c|}
\hline Criteria & \multicolumn{4}{|c|}{ Compliance Requirements } & Documents \\
\hline \multirow[b]{2}{*}{ Requirement } & \multirow[b]{2}{*}{ Single Entity } & \multicolumn{3}{|c|}{ Joint Venture } & \multirow[b]{2}{*}{$\begin{array}{c}\text { Submission } \\
\text { Requirements }\end{array}$} \\
\hline & & $\begin{array}{c}\text { All Partners } \\
\text { Combined }\end{array}$ & $\begin{array}{c}\text { Each } \\
\text { Partner }\end{array}$ & $\begin{array}{c}\text { One } \\
\text { Partner }\end{array}$ & \\
\hline 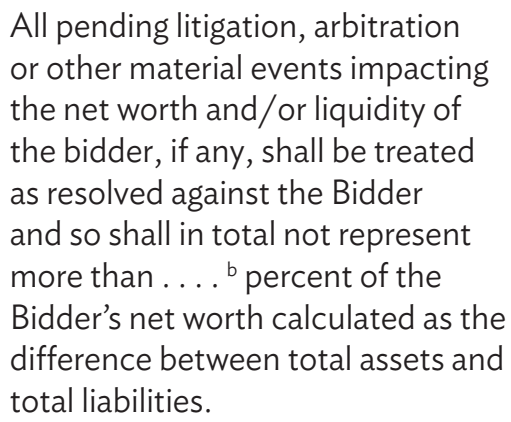 & $\begin{array}{l}\text { Must meet } \\
\text { requirement }\end{array}$ & $\begin{array}{c}\text { Not } \\
\text { applicable }\end{array}$ & $\begin{array}{l}\text { Must meet } \\
\text { requirement }\end{array}$ & $\begin{array}{c}\text { Not } \\
\text { applicable }\end{array}$ & Form CON - 1 \\
\hline
\end{tabular}

a The Employer may choose whether to apply or not to apply this criterion:

1) If the Employer chooses to apply this criterion, it should indicate "shall apply" and use the table in 2.2.3, or

2) If the Employer chooses not to apply this criterion, it should indicate "shall not apply" and delete the table in 2.2.3.

b If the criterion is applied, the Employer should indicate a percentage within the range of $50 \%-100 \%$ of the Bidder's net worth.

\subsubsection{Declaration: Environmental and Health and Safety Past Performance}

\begin{tabular}{|c|c|c|c|c|c|}
\hline Criteria & \multicolumn{4}{|c|}{ Compliance Requirements } & Documents \\
\hline \multirow[b]{2}{*}{ Requirement } & \multirow[b]{2}{*}{ Single Entity } & \multicolumn{3}{|c|}{ Joint Venture } & \multirow[b]{2}{*}{$\begin{array}{l}\text { Submission } \\
\text { Requirements }\end{array}$} \\
\hline & & $\begin{array}{c}\text { All Partners } \\
\text { Combined }\end{array}$ & $\begin{array}{c}\text { Each } \\
\text { Partner }\end{array}$ & $\begin{array}{c}\text { One } \\
\text { Partner }\end{array}$ & \\
\hline $\begin{array}{l}\text { Declare any contracts } \\
\text { that have been suspended } \\
\text { or terminated and/or } \\
\text { performance security } \\
\text { called by an employer } \\
\text { for reasons related to the } \\
\text { noncompliance of any } \\
\text { environmental, health } \\
\text { and safety contractual } \\
\text { obligations in the past } \\
\text { five years. }{ }^{a}\end{array}$ & $\begin{array}{l}\text { Must make the } \\
\text { declaration. If the } \\
\text { bidder proposes } \\
\text { Specialist } \\
\text { Subcontractor/s } \\
\text { to meet EQC } \\
2.4 .2 \text {, those } \\
\text { Specialist } \\
\text { Subcontractor/s } \\
\text { must also make } \\
\text { the declaration }\end{array}$ & $\begin{array}{c}\text { Not } \\
\text { applicable }\end{array}$ & $\begin{array}{l}\text { Each partner } \\
\text { must make the } \\
\text { declaration. If the } \\
\text { bidder proposes } \\
\text { Specialist } \\
\text { Subcontractor/s } \\
\text { to meet EQC } \\
2.4 .2 \text {, those } \\
\text { Specialist } \\
\text { Subcontractor/s } \\
\text { must also make } \\
\text { the declaration. }\end{array}$ & $\begin{array}{c}\text { Not } \\
\text { applicable }\end{array}$ & Form $\mathrm{CON}-2$ \\
\hline
\end{tabular}

a The Employer may use this information to seek further information or clarifications regarding corrective actions undertaken by the contractor during the bidding stage and the associated due diligence. 


\subsection{Financial Situation}

\subsubsection{Historical Financial Performance}

\begin{tabular}{|c|c|c|c|c|c|}
\hline \multirow[b]{3}{*}{ Requirement } & \multicolumn{4}{|c|}{ Compliance Requirements } & Documents \\
\hline & \multirow[b]{2}{*}{ Single Entity } & \multicolumn{3}{|c|}{ Joint Venture } & \multirow[b]{2}{*}{$\begin{array}{l}\text { Submission } \\
\text { Requirements }\end{array}$} \\
\hline & & $\begin{array}{c}\text { All Partners } \\
\text { Combined }\end{array}$ & $\begin{array}{c}\text { Each } \\
\text { Partner }\end{array}$ & $\begin{array}{c}\text { One } \\
\text { Partner }\end{array}$ & \\
\hline $\begin{array}{l}\text { Submission of audited financial } \\
\text { statements or, if not required by the } \\
\text { law of the Bidder's country, other } \\
\text { financial statements acceptable to the } \\
\text { Employer, for the last ....... } \text {. years } \\
\text { to demonstrate the current soundness } \\
\text { of the Bidder's financial position. As a } \\
\text { minimum, the Bidder's net worth } \\
\text { for the last year calculated as the } \\
\text { difference between total assets and } \\
\text { total liabilities should be positive. }\end{array}$ & $\begin{array}{l}\text { Must meet } \\
\text { requirement }\end{array}$ & $\begin{array}{c}\text { Not } \\
\text { applicable }\end{array}$ & $\begin{array}{l}\text { Must meet } \\
\text { requirement }\end{array}$ & $\begin{array}{c}\text { Not } \\
\text { applicable }\end{array}$ & $\begin{array}{l}\text { Form } \\
\text { FIN }-1 \text { with } \\
\text { attachments }\end{array}$ \\
\hline
\end{tabular}

a Indicate time period between 3 and 5 years.

\section{NOTE}

The financial information provided by the Bidder should be reviewed in its entirety to allow a truly informed judgment, and the pass-fail decision on the financial position of the Bidder should be given on this basis. Any abnormal feature that may lead to financial problems should alert the Employer to seek expert professional advice for further review and interpretation. 


\subsubsection{Average Annual Turnover}

\begin{tabular}{|c|c|c|c|c|c|}
\hline Criteria & \multicolumn{4}{|c|}{ Compliance Requirements } & Documents \\
\hline \multirow[b]{2}{*}{ Requirement } & \multirow[b]{2}{*}{ Single Entity } & \multicolumn{3}{|c|}{ Joint Venture } & \multirow[b]{2}{*}{$\begin{array}{l}\text { Submission } \\
\text { Requirements }\end{array}$} \\
\hline & & $\begin{array}{c}\text { All Partners } \\
\text { Combined }\end{array}$ & $\begin{array}{c}\text { Each } \\
\text { Partner }\end{array}$ & $\begin{array}{c}\text { One } \\
\text { Partner }\end{array}$ & \\
\hline $\begin{array}{l}\text { Minimum average annual } \\
\text { turnover of } \$ \ldots \ldots \ldots \ldots \\
\text { calculated as total certified } \\
\text { payments received for contracts } \\
\text { in progress or completed, within } \\
\text { the last . . . . . . b years. }\end{array}$ & $\begin{array}{l}\text { Must meet } \\
\text { requirement }\end{array}$ & $\begin{array}{l}\text { Must meet } \\
\text { requirement }\end{array}$ & $\begin{array}{l}\text { Must meet } \\
\ldots \ldots \ldots{ }^{c} \\
\text { of the } \\
\text { requirement }\end{array}$ & $\begin{array}{l}\text { Must meet } \\
\ldots \ldots \ldots \\
\text { of the } \\
\text { requirement }\end{array}$ & $\begin{array}{c}\text { Form FIN - } 1 \\
\text { with } \\
\text { attachments }\end{array}$ \\
\hline
\end{tabular}

a The amount stated should normally not be less than two times the annualized value of the subject contract, expressed as $2 \times \mathrm{V} / \mathrm{T}$; where $\mathrm{V}$ is the Employer's estimated cost (including contingencies), $\mathrm{T}$ is the contract duration in years. For contract duration of up to 1 year, T of "1" should be used. The multiplier of 2 may be reduced for very large contracts but should not be less than 1.5 .

b Insert number of years in words and figures and indicate time period between 3 and 5 years.

c The Employer is to define this value based on the minimum amount required that all partners of the Joint Venture must meet taking joint and several liability into account, usually at least $25 \%$.

d The Employer is to define this value based on the minimum amount required that one partner of the Joint Venture must meet, usually at least $40 \%$. 


\subsubsection{Financial Resources ${ }^{2}$}

If the bid evaluation process and the decision for the award of the Contract takes more than 1 year from the date of bid submission, Bidders may be asked to resubmit their current contract commitments and latest information on financial resources supported by latest audited accounts or audited financial statements, or if not required by the law of the Bidder's country, other financial statements acceptable to the Employer, and the Bidders' financial capacity will be reassessed on this basis.

\begin{tabular}{|c|c|c|c|c|c|}
\hline \multicolumn{2}{|l|}{ Criteria } & \multicolumn{3}{|c|}{ Compliance Requirements } & Documents \\
\hline \multirow[b]{2}{*}{ Requirement } & \multirow[b]{2}{*}{$\begin{array}{l}\text { Single } \\
\text { Entity }\end{array}$} & \multicolumn{3}{|c|}{ Joint Venture } & \multirow[b]{2}{*}{$\begin{array}{l}\text { Submission } \\
\text { Requirements }\end{array}$} \\
\hline & & $\begin{array}{l}\text { All Partners } \\
\text { Combined }\end{array}$ & $\begin{array}{l}\text { Each } \\
\text { Partner }\end{array}$ & $\begin{array}{l}\text { One } \\
\text { Partner }\end{array}$ & \\
\hline $\begin{array}{l}\text { For Single Entities: } \\
\text { The Bidder must demonstrate } \\
\text { that its financial resources defined } \\
\text { in Form FIN - 3, less its financial } \\
\text { obligations for its current contract } \\
\text { commitments defined in Form } \\
\text { FIN - 4, meet or exceed the } \\
\text { total requirement for the Subject } \\
\text { Contract of .............. }{ }^{\text {a }}\end{array}$ & $\begin{array}{l}\text { Must meet } \\
\text { requirement }\end{array}$ & $\begin{array}{c}\text { Not } \\
\text { applicable }\end{array}$ & $\begin{array}{c}\text { Not } \\
\text { applicable }\end{array}$ & $\begin{array}{c}\text { Not } \\
\text { applicable }\end{array}$ & $\begin{array}{c}\text { Form FIN }-3 \text { and } \\
\text { Form FIN }-4\end{array}$ \\
\hline $\begin{array}{l}\text { For Joint Ventures: } \\
\text { (1) One partner must } \\
\text { demonstrate that its financial } \\
\text { resources defined in Form } \\
\text { FIN - 3, less its financial } \\
\text { obligations for its own current } \\
\text { contract commitments } \\
\text { defined in Form FIN - } 4 \text {, meet } \\
\text { or exceed its required share } \\
\text { of .............. b from the total } \\
\text { requirement for the Subject } \\
\text { Contract. }\end{array}$ & $\begin{array}{c}\text { Not } \\
\text { applicable }\end{array}$ & $\begin{array}{c}\text { Not } \\
\text { applicable }\end{array}$ & $\begin{array}{c}\text { Not } \\
\text { applicable }\end{array}$ & $\begin{array}{l}\text { Must meet } \\
\text { requirement }\end{array}$ & $\begin{array}{l}\text { Form FIN - } 3 \\
\text { and } \\
\text { Form FIN - } 4\end{array}$ \\
\hline AND & & & & & \\
\hline
\end{tabular}

2 The Employer has the option to move this criterion from Section 3 (Evaluation and Qualification Criteria) to Section 6 (Employer's Requirements), in which case,

(a) the Employer shall confirm compliance with the financial resources criterion prior to award of contract in accordance with ITB 53.1 Award Criteria; and

(b) in place of the financial resources criterion, the Employer may require the Bidder to submit together with its bid, and for confirmation during bid evaluation, a letter of undertaking to comply with the financial resources given in Section 6 prior to award of contract. 


\begin{tabular}{|c|c|c|c|c|c|}
\hline Criteria & \multicolumn{4}{|c|}{ Compliance Requirements } & Documents \\
\hline \multirow[b]{2}{*}{ Requirement } & \multirow[b]{2}{*}{$\begin{array}{l}\text { Single } \\
\text { Entity }\end{array}$} & \multicolumn{3}{|c|}{ Joint Venture } & \multirow[b]{2}{*}{$\begin{array}{c}\text { Submission } \\
\text { Requirements }\end{array}$} \\
\hline & & $\begin{array}{l}\text { All Partners } \\
\text { Combined }\end{array}$ & $\begin{array}{c}\text { Each } \\
\text { Partner }\end{array}$ & $\begin{array}{c}\text { One } \\
\text { Partner }\end{array}$ & \\
\hline $\begin{array}{l}\text { (2) Each partner must } \\
\text { demonstrate that its financial } \\
\text { resources defined in Form } \\
\text { FIN - 3, less its financial } \\
\text { obligations for its own current } \\
\text { contract commitments } \\
\text { defined in Form FIN - } 4 \text {, } \\
\text { meet or exceed its required } \\
\text { share of .............. }{ }^{c} \text { from } \\
\text { the total requirement for the } \\
\text { Subject Contract. } \\
\text { AND }\end{array}$ & $\begin{array}{c}\text { Not } \\
\text { applicable }\end{array}$ & $\begin{array}{c}\text { Not } \\
\text { applicable }\end{array}$ & $\begin{array}{l}\text { Must meet } \\
\text { requirement }\end{array}$ & $\begin{array}{c}\text { Not } \\
\text { applicable }\end{array}$ & $\begin{array}{c}\text { Form FIN }-3 \text { and } \\
\text { Form FIN }-4\end{array}$ \\
\hline $\begin{array}{l}\text { (3) The Joint Venture must } \\
\text { demonstrate that the } \\
\text { combined financial resources } \\
\text { of all partners defined in Form } \\
\text { FIN - 3, less all the partners' } \\
\text { total financial obligations } \\
\text { for the current contract } \\
\text { commitments defined in } \\
\text { Form FIN - 4, meet or exceed } \\
\text { the total requirement for the } \\
\text { Subject Contract of .............. }\end{array}$ & $\begin{array}{c}\text { Not } \\
\text { applicable }\end{array}$ & $\begin{array}{l}\text { Must meet } \\
\text { requirement }\end{array}$ & $\begin{array}{c}\text { Not } \\
\text { applicable }\end{array}$ & $\begin{array}{c}\text { Not } \\
\text { applicable }\end{array}$ & $\begin{array}{l}\text { Form FIN }-3 \text { and } \\
\text { Form FIN }-4\end{array}$ \\
\hline
\end{tabular}

a The Employer is to specify the total requirement for the Subject Contract based on the following calculation:

\section{$\underline{3 \text { (or 4) } x \text { Estimated Contract Value (Inclusive of Taxes and Duties) }}$}

Completion Period in Months

b The Employer is to define this value based on the minimum amount one partner of the Joint Venture must meet, usually at least $40 \%$ of the total requirement for the Subject Contract. This value is to be carried forward to Form FIN - 5B when it is used.

c The Employer is to define this value based on the minimum amount each partner of the Joint Venture must meet, usually at least $25 \%$ of the total requirement for the Subject Contract. This value is to be carried forward to Form FIN - 5B when it is used.

\section{NOTE}

Form FIN - 5 is made available for use by the Bidder as a self-assessment tool, and by the Employer as an evaluation work sheet, to determine compliance with the financial resources requirement as stated in 2.3.3. Failure to submit Form FIN - 5 by the Bidder shall not lead to bid rejection. 


\subsection{Bidder's Experience}

\subsubsection{Contracts of Similar Size and Nature ${ }^{3}$}

\begin{tabular}{|c|c|c|c|c|c|}
\hline Criteria & \multicolumn{4}{|c|}{ Compliance Requirements } & Documents \\
\hline \multirow[b]{2}{*}{ Requirement } & \multicolumn{4}{|c|}{ Joint Venture } & \multirow[b]{2}{*}{$\begin{array}{l}\text { Submission } \\
\text { Requirements }\end{array}$} \\
\hline & $\begin{array}{l}\text { Single } \\
\text { Entity }\end{array}$ & $\begin{array}{l}\text { All Partners } \\
\text { Combined }\end{array}$ & $\begin{array}{l}\text { Each } \\
\text { Partner }\end{array}$ & $\begin{array}{l}\text { One } \\
\text { Partner }\end{array}$ & \\
\hline $\begin{array}{l}\text { Participation as a contractor, Joint } \\
\text { venture partner, or Subcontractor, } \\
\text { in at least one contract that has } \\
\text { been satisfactorily and substantially } \\
\text { completed within the last .... b years } \\
\text { and that is similar to the proposed } \\
\text { contract, where the value of the } \\
\text { Bidder's participation exceeds } \$ \ldots \\
\ldots \ldots \text {. The similarity of the Bidder's } \\
\text { participation shall be based on: }{ }^{\mathrm{d}, \mathrm{e}, \mathrm{f}} \\
1 \ldots \\
2 \ldots \\
3 \ldots\end{array}$ & $\begin{array}{l}\text { Must meet } \\
\text { requirement }\end{array}$ & $\begin{array}{c}\text { Not } \\
\text { applicable }\end{array}$ & $\begin{array}{c}\text { Not } \\
\text { applicables }\end{array}$ & $\begin{array}{l}\text { Must meet } \\
\text { requirement }\end{array}$ & Form EXP $-1^{h}$ \\
\hline
\end{tabular}

Or

3 The Employer has the option of requiring either one or two contracts of similar size and nature and should choose the appropriate language for the table in 2.4.1. 


\begin{tabular}{|c|c|c|c|c|c|}
\hline Criteria & \multicolumn{4}{|c|}{ Compliance Requirements } & Documents \\
\hline \multirow[b]{2}{*}{ Requirement } & \multirow[b]{2}{*}{$\begin{array}{l}\text { Single } \\
\text { Entity }\end{array}$} & \multicolumn{3}{|c|}{ Joint Venture } & \multirow[b]{2}{*}{$\begin{array}{c}\text { Submission } \\
\text { Requirements }\end{array}$} \\
\hline & & $\begin{array}{l}\text { All Partners } \\
\text { Combined }\end{array}$ & $\begin{array}{c}\text { Each } \\
\text { Partner }\end{array}$ & $\begin{array}{c}\text { One } \\
\text { Partner }\end{array}$ & \\
\hline $\begin{array}{l}\text { Participation as a contractor, Joint } \\
\text { venture partner, or Subcontractor, } \\
\text { in at least two contracts that } \\
\text { have been satisfactorily and } \\
\text { substantially }{ }^{\text {a }} \text { completed within } \\
\text { the last .... . years and that are } \\
\text { similar to the proposed contract, } \\
\text { where the value of the Bidder's } \\
\text { participation under each contract } \\
\text { exceeds } \$ \ldots . . . \text { c }^{\text {The similarity }} \\
\text { of the Bidder's participation } \\
\text { shall be based on: }{ }^{\mathrm{d}, \mathrm{e}, \mathrm{f}} \\
1 \ldots \\
2 \ldots \\
3 \ldots\end{array}$ & $\begin{array}{l}\text { Must meet } \\
\text { requirement }\end{array}$ & $\begin{array}{l}\text { Must meet } \\
\text { requirement } \\
\text { as follows: } \\
\text { (i) Either one } \\
\text { partner must } \\
\text { meet requirement } \\
\text { Or } \\
\text { (ii) any two } \\
\text { partners } \\
\text { must each } \\
\text { demonstrate one } \\
\text { (1) satisfactorily } \\
\text { and substantially } \\
\text { completed } \\
\text { contract of similar } \\
\text { size and nature }\end{array}$ & $\begin{array}{c}\text { Not } \\
\text { applicable }\end{array}$ & $\begin{array}{c}\text { Not } \\
\text { applicable }\end{array}$ & Form EXP $-1^{\mathrm{h}}$ \\
\hline
\end{tabular}

a The requirement of "substantially completed contract" may vary from bid package to bid package. The requirement of "substantially completed contract" should be carefully reflected in the documents required to be submitted by bidders, to avoid potential issues in bid evaluation (refer Note ' $h$ ' below). For further guidance on substantial completion of contracts, refer to ADB's Guidance Note on Procurement: Open Competitive Bidding.

b Insert number of years in words and figures. The range is normally 5-10 years.

c Usually $80 \%$ of the estimated value of the subject contract. In case of repetitive and contiguous works (e.g., transmission lines, water pipeline), the Employer has the option of specifying a value that is between $50 \%$ and $80 \%$ of the subject contract value. If the contract value is not in the specific currency, the exchange rate to be used to calculate the value of the contract shall be the selling rate of the Borrower's cental bank on the date of the contract.

d Specify major requirements in terms of any of the following: physical size, nature of works, complexity, methods, technology, or other characteristics.

e For contracts under which the Bidder participated as a Joint Venture partner or Subcontractor, only the Bidder's share, by value, shall be considered to meet this requirement.

f For contracts implemented by a Joint Venture contractor, if the Bidder comprises the same Joint Venture, the 'Single Entity' requirements will apply.

8 In case of complex works, the Employer may require each partner to demonstrate one satisfactorily and substantially completed contract of similar nature where such partner's value of participation exceeds $25 \%$ of the subject contract value.

$\mathrm{h}$ In addition to the submission requirement Form EXP - 1, the bidder shall provide the following supporting documents:

[If the Employer will consider a "substantially completed contract" as one in which the works have been completed, insert the following text:

1. Signed Contract Agreement, and

2. Taking-Over Certificate, Contract Completion Certificate or Performance Certificate,

in sufficient detail to verify the contract name, value and completion time (or substantial completion). If the documents are other than in English, an accurate certified translation of these documents in English shall be provided.]

[If the Employer will consider a "substantially completed contract" as one in which the Contractor has completed all its obligations under the contract, insert the following text:

1. Signed Contract Agreement, and

2. Contract Completion Certificate or Performance Certificate,

in sufficient detail to verify the contract name, value and completion time. If the documents are other than in English, an accurate certified translation of these documents in English shall be provided.] 


\subsubsection{Experience in Key Activities ${ }^{4}$}

2.4.2(a) Must be complied with by the Bidder. In case of a Joint Venture Bidder, the Bidder or at least one of the partners must meet the requirement in the key activity. For contracts under which the Bidder participated as a Joint Venture partner, only the Bidder's designated scope of works under the contracts shall be considered to meet this requirement.

Table A

\begin{tabular}{|l|c|c|c|}
\multicolumn{1}{|c|}{ Criteria } & \multicolumn{1}{c|}{ Compliance Requirements } & Documents \\
\hline $\begin{array}{l}\text { Ror the above or other contracts } \\
\text { executed during the period } \\
\text { stipulated in 2.4.1, a minimum } \\
\text { construction experience in the } \\
\text { following key activities: }\end{array}$ & Single Entity & Joint Venture & $\begin{array}{c}\text { Submission } \\
\text { Requirements }\end{array}$ \\
\hline $1 \ldots \ldots .$. & Must meet requirement & Must meet requirement & Form EXP $-2^{\mathrm{b}}$ \\
\hline $2 \ldots \ldots . .$. & & \\
\hline $3 .$. etc .... & & & \\
\hline
\end{tabular}

a Under Criterion 2.4.1, the specified requirements define the similarity of contracts, whereas the key activities or production rates to be specified under Criterion 2.4.2 define the required capability of the Bidder to execute key components of the works. There shall be no inconsistency or duplication of requirements between Criteria 2.4.1 and 2.4.2. For the rate of production, specify that the rate of production shall be on the basis of the average during the entire specified period.

b Submission requirements: Form EXP - 2 shall be supported by documents such as Signed Contract Agreement, Taking-Over Certificate or Contract Completion Certificate indicating the contract name, value. completion date (or percentage of substantial completion), activities performed by Joint Venture partners, and other relevant details sufficient to demonstrate compliance with the requirements.

2.4.2(b) The Employer accepts any of the following activities to be subcontracted. They may be complied with by the Bidder or by its proposed Specialist Subcontractor.

If the key activity is to be undertaken by a Specialist Subcontractor, the Employer shall require evidence of the subcontracting agreement from the Bidder.

$4 \quad$ Key activities criterion should confirm Bidder's experience in performing highly specialized activities such as design, installation, testing, commissioning, etc. There shall not be any inconsistency or repetition of requirements between 2.4.1 and 2.4.2. 
Table B

\begin{tabular}{|c|c|c|c|}
\hline Criteria & \multicolumn{2}{|c|}{ Compliance Requirements } & Documents \\
\hline Requirement & $\begin{array}{c}\text { Single Entity or Its } \\
\text { Specialist Subcontractors }\end{array}$ & $\begin{array}{c}\text { Joint Venture or Its } \\
\text { Specialist Subcontractors }\end{array}$ & $\begin{array}{c}\text { Submission } \\
\text { Requirements }\end{array}$ \\
\hline $\begin{array}{l}\text { For the above or other contracts } \\
\text { executed during the period } \\
\text { stipulated in } 2.4 .1 \text {, a minimum } \\
\text { experience in the following key } \\
\text { activities: }^{\text {a }}\end{array}$ & $\begin{array}{l}\text { One must meet } \\
\text { requirement }\end{array}$ & $\begin{array}{l}\text { One must meet } \\
\text { requirement }\end{array}$ & Form EXP $-2^{b}$ \\
\hline $4 \ldots \ldots \ldots$ & & & \\
\hline $5 \ldots \ldots$ & & & \\
\hline 6 .. etc .... & & & \\
\hline
\end{tabular}

a Under Criterion 2.4.1, the specified requirements define the similarity of contracts, whereas the key activities or production rates to be specified under Criterion 2.4.2 define the required capability of the Bidder to execute key components of the works. There shall be no inconsistency or duplication of requirements between Criteria 2.4.1 and 2.4.2. For the rate of production, specify that the rate of production shall be on the basis of the average during the entire specified period.

b The compliance requirement for each key activity that may be met by a specialist subcontractor must define whether the requirement can only be met by a single specialist subcontractor or whether two or more specialist subcontractors can jointly meet the requirement.

c Submission requirements: Form EXP - 2 shall be supported by documents such as Signed Contract Agreement, Taking-Over Certificate or Contract Completion Certificate indicating the contract name, value, completion date (or percentage of substantial completion), activities performed by Joint Venture partners, and other relevant details sufficient to demonstrate compliance with the requirements.

\subsubsection{Specific Experience in Managing Environmental, Health and Safety Aspects}

\begin{tabular}{|c|c|c|c|}
\hline Criteria & \multicolumn{2}{|c|}{ Compliance Requirements } & Documents \\
\hline Requirement & $\begin{array}{c}\text { Single Entity or Its } \\
\text { Specialist Subcontractors }\end{array}$ & $\begin{array}{c}\text { Joint Venture or Its } \\
\text { Specialist Subcontractors }\end{array}$ & $\begin{array}{l}\text { Submission } \\
\text { Requirement }\end{array}$ \\
\hline $\begin{array}{l}\text { For the contracts in } 2.4 .1 \text { and } 2.4 .2 \\
\text { above and/or any other contracts } \\
\text { [substantially completed and } \\
\text { under implementation] as prime } \\
\text { contractor, Joint Venture partner, or } \\
\text { Subcontractor between 1st January } \\
\ldots \ldots{ }^{a} \text { and Bid submission deadline, } \\
\text { experience in managing EHS } \\
\text { risks and impacts in the following } \\
\text { aspects: }\end{array}$ & Must meet requirement & $\begin{array}{l}\text { One member must } \\
\text { meet requirements } \\
\text { or } \\
\text { All members must } \\
\text { meet requirements }\end{array}$ & Form EXP - 3 \\
\hline
\end{tabular}

\footnotetext{
a Insert year.

b Based on the EHS assessment, specify, as appropriate, specific experience requirements to manage EHS aspects.
} 


\subsection{Organizational Environmental, Health and Safety System}

\subsubsection{Environmental, Health and Safety Certification}

\begin{tabular}{|c|c|c|c|}
\hline Criteria & \multicolumn{2}{|c|}{ Compliance Requirements } & Documents \\
\hline Requirement & $\begin{array}{c}\text { Single Entity or Its } \\
\text { Specialist Subcontractors }\end{array}$ & $\begin{array}{c}\text { Joint Venture or Its } \\
\text { Specialist Subcontractors }\end{array}$ & $\begin{array}{l}\text { Submission } \\
\text { Requirement }\end{array}$ \\
\hline $\begin{array}{l}\text { Availability of a valid ISO } \\
\text { certification or internationally } \\
\text { recognized equivalent (equivalency } \\
\text { to be demonstrated by the Bidder), } \\
\text { and applicable to the worksite: }{ }^{a, b}\end{array}$ & Must meet requirement & $\begin{array}{l}\text { One member must } \\
\text { meet requirements } \\
\text { or } \\
\text { All members must meet } \\
\text { requirements }\end{array}$ & Form EXP - 4 \\
\hline $1 \ldots \ldots \ldots$ & & & \\
\hline $2 \ldots \ldots \ldots$ & & & \\
\hline $3 \ldots \ldots \ldots$ & & & \\
\hline
\end{tabular}

a Examples of certification that can be selected:

1. Quality management certificate ISO 9001

2. Environmental management certificate ISO 14001

3. Health and Safety management certificate ISO 45001

b According to the environmental, health and safety issues of the worksite and the type of competition planned (national or international), it can be decided to not to keep this criterion or only to ask for part of the certifications, specifically the one(s) corresponding to the main issue of the worksite management 
2.5.2 Environmental, Health and Safety Documentation

\begin{tabular}{|c|c|c|c|}
\hline Criteria & \multicolumn{2}{|c|}{ Compliance Requirements } & Documents \\
\hline Requirement & $\begin{array}{c}\text { Single Entity or Its } \\
\text { Specialist Subcontractors }\end{array}$ & $\begin{array}{l}\text { Joint Venture or Its } \\
\text { Specialist Subcontractors }\end{array}$ & $\begin{array}{l}\text { Submission } \\
\text { Requirement }\end{array}$ \\
\hline $\begin{array}{l}\text { Availability of in-house policies and } \\
\text { procedures for EHS management: } \\
\text { For example: } \\
\text { 1. Existence of an Ethics Charter. } \\
\text { 2. Existence of a system for } \\
\text { monitoring compliance with EHS } \\
\text { commitments for the Bidder's } \\
\text { Subcontractors and all its partners. } \\
\text { 3. Existence of official company } \\
\text { procedures for the management of } \\
\text { the following: } \\
-\quad \ldots \ldots \ldots . \\
-\ldots \ldots . . . \\
-\quad \ldots . . . . . \\
-\end{array}$ & Must meet requirements & $\begin{array}{l}\text { One member must meet } \\
\text { requirements } \\
\text { or } \\
\text { All members must meet } \\
\text { requirements }\end{array}$ & Form EXP - 5 \\
\hline
\end{tabular}

a From the below options, the Employer to select 3-5 that apply to the worksite. The selection should be based on the most pressing EHS issues pertaining to the worksite as detailed in the project EMP.

- EHS resources and facilities and EHS monitoring system;

- Project Areas management information (base camps, quarries, burrow pits, storage areas);

- Health and Safety on worksites policy and related guidance;

- Local recruitment and EHS trainings of local staff/subcontractors/local partners;

- Community stakeholder engagement practice;

- Traffic management practice;

- Hazardous products management practice;

- Waste management practice;

- Protection of water resources;

- Biodiversity protection practices;

- Site rehabilitation and revegetation practice;

- Local cultural heritage protection practice;

- Erosion and sedimentation practices;

- Control of infectious and communicable diseases (HIV/AIDS, malaria, COVID-19 etc)

\subsubsection{Environmental, Health and Safety Dedicated Personnel}

\begin{tabular}{|c|c|c|c|}
\hline Criteria & \multicolumn{2}{|c|}{ Compliance Requirements } & Documents \\
\hline Requirement & $\begin{array}{l}\text { Single Entity or its } \\
\text { Specialist Subcontractors }\end{array}$ & $\begin{array}{l}\text { Joint Venture or its } \\
\text { Specialist Subcontractors }\end{array}$ & $\begin{array}{c}\text { Submission } \\
\text { Requirements }\end{array}$ \\
\hline $\begin{array}{l}\text { Availability of in-house personnel } \\
\text { dedicated to EHS issues: } \\
\text { - Environmental Specialist } \\
\text { - Health and Safety Specialist }\end{array}$ & Must meet requirement & $\begin{array}{l}\text { One member must meet } \\
\text { requirements } \\
\text { or } \\
\text { All members must meet } \\
\text { requirements }\end{array}$ & Form EXP - 6 \\
\hline
\end{tabular}




\subsection{Subcontractors}

Subcontractors or Manufacturers for the following major items of plant and services must meet the following minimum qualification criteria, herein listed for a Subcontractor for that item. Failure to comply with this requirement will result in rejection of the Subcontractor but not the Bidder.

\begin{tabular}{|c|c|c|c|}
\begin{tabular}{c|c|c|} 
Item \\
No.
\end{tabular} & Description of Item & $\begin{array}{c}\text { Minimum Criteria } \\
\text { to be met }^{2}\end{array}$ & $\begin{array}{c}\text { Documents } \\
\text { Submission } \\
\text { Requirements }^{*}\end{array}$ \\
\hline 1 & & & \multirow{2}{*}{ Form EXP -7 } \\
\hline 2 & & \\
\hline 3 & & & \\
\hline 4 & & & \\
\hline & & & \\
\hline & & & \\
\hline
\end{tabular}

a Subcontractor must have the experience of having completed at least one contract of size and complexity similar to the proposed subcontract within the last 3 or 5 years.

In the case of a Bidder who offers to supply and install major items of plant under the contract, which the Bidder did not manufacture or otherwise produce, the Bidder shall provide the Manufacturer's authorization, using the form provided in Section 4 (Bidding Forms), showing that the Bidder has been duly authorized by the Manufacturer or producer of the related plant and equipment or component to supply and install that item in the Employer's country. Failure to submit the Manufacturer's authorization at the first instance is considered a minor, nonmaterial omission and shall be subject to clarification. However, failure of the Bidder to submit the omitted authorization shall lead to rejection of the Subcontractor or Manufacturer of the item under evaluation in accordance with ITB 50.3. 


\section{B. Second-Stage Evaluation}

\section{Economic Evaluation}

In addition to the criteria listed in ITB 48.3 I (a)-(f), other relevant factors are as follows:

Adjustments in price that result from the procedures stated below shall be added, for purposes of comparative evaluation only, to arrive at an "Evaluated Bid Price." Bid prices quoted by Bidders shall remain unaltered.

\subsection{Quantifiable Deviations and Omissions}

Quantifiable Deviations and Omissions from the contractual obligations: the evaluation shall be based on the evaluated cost of fulfilling the contract in compliance with all contractual obligations under this Bidding Document.

[Insert: "Pursuant to ITB 44.3, the cost of all quantifiable nonmaterial nonconformities or omissions from the contractual and commercial conditions shall be evaluated. The Employer will make its own assessment of the cost of any nonmaterial nonconformities and omissions for the purpose of ensuring fair comparison of Bids."]

\section{NOTE}

Subject to ITB 31.1 and ITB 31.2, the cost of minor omissions or missing items should be added to the bid price to allow for bid comparison on an equal basis. The price adjustment should be based on a reasonable estimate of the cost by the executing agency, engineer, consultant or bid evaluation committee, taking into consideration the corresponding quoted prices from other conforming bids. The price adjustment should be based on the fair price of the omitted item. The most frequently used method is to use the price equal to the highest price quoted for the same item by the other responsive Bidders.

\subsection{Operation and Maintenance Costs}

Since the operation and maintenance $(O \& M)$ costs of the facilities being procured form a major part of the life cycle cost of the facilities, these costs will be evaluated according to the principles given hereafter, including the cost of spare parts for the initial period of operation stated below and based on prices furnished by each Bidder in Price Schedule Nos. 1 and 2, as well as on past experience of the Employer or other employers similarly placed. Such costs shall be added to the bid price for evaluation. The price of recommended spare parts quoted in Price Schedule No. 6 shall not be considered for evaluation. Use of unverifiable future O\&M cost and consumption figures as a factor in economic evaluation should be avoided.

\section{NOTE}

Use one of the two options given below. 
The O\&M cost factors for calculating of the life cycle cost are as follows:

(a) Number of years for life cycle [insert life cycle period in years. Usually, the period should not exceed the usual period before a major overhaul of the facilities becomes necessary]

(b) Operating costs [insert fuel and/or other input, unit cost for annual and total operational requirements]

(c) Maintenance costs, including the cost of spare parts for the initial period of operation

(d) A rate of [insert rate in words and figures] in percentage to be used to discount to present value all annual future costs calculated under (b) and (c) for the period specified in (a)

or

[insert a reference to the methodology specified in the specification or elsewhere in the bidding document]

\subsection{Functional Guarantees of the Facilities}

The minimum and/or maximum requirements stated in the Specification for functional guarantees required in the Specification are the following:

[insert appropriate reference to the functional guarantees, and use text suggested below]

\begin{tabular}{|l|l|}
\multicolumn{1}{c|}{$\begin{array}{c}\text { Functional Guarantee } \\
\text { [as required in the Specification, e.g., performance, } \\
\text { efficiency, consumption, etc.] }\end{array}$} & $\begin{array}{c}\text { Minimum and/or Maximum Requirements } \\
\text { [as required in the Specification] }\end{array}$ \\
\hline 1. & \\
\hline 2. & \\
\hline 3. & \\
\hline$\ldots$ & \\
\hline
\end{tabular}

For the purposes of evaluation, for each percentage point in performance or efficiency below the norm specified in the Specification but above the minimum acceptable levels also specified there, an adjustment of [insert amount in the currency of bid evaluation] will be added to the bid price.

\subsection{Work, Services, Facilities, etc., to Be Provided by the Employer}

Where Bids include the undertaking of work or the provision of services or facilities by the Employer in excess of the provisions allowed for in the Bidding Document, the Employer shall assess the costs of such additional work, services, and/or facilities during the duration of the contract. Such costs shall be added to the bid price for evaluation.

\subsection{Specific Additional Criteria}

The following additional criteria will be used in the evaluation:

[if applicable, insert a list of additional criteria or a reference to criteria specified elsewhere in the Bidding Document] 
Add any other relevant criteria to consider in bid evaluation, such as quality, responsiveness to socioeconomic or environmental objective, sustainable procurement technical requirements that have been specified in Section 6, special security considerations at site, and Bidder's records of achieving the desired results based on experience and performance history. For each criteria, clearly specify the evaluation methodology, e.g. (i) any relevant requirement specified in Section 6 will be evaluated on a pass/fail (compliance basis), (ii) in addition to evaluating that requirement on a pass/fail (compliance basis), if applicable, specify the monetary adjustments to be applied to bid prices for comparison purposes on account of bids that exceed the specified minimum requirements, or (iii) if merit point scoring is applied in the evaluation, the criteria will be the one of the technical factors.

\subsubsection{Environmental, Health and Safety Management Plan (EHSMP)}

Any bid not accompanied by the EHSMP may be rejected by the Employer as nonresponsive. If a Bidder submits a EHSMP that is not commensurate with the risks and impacts of the proposed works and activities in the bidding document, the Employer shall issue a clarification to request for further information from the Bidder. The Bidder must submit the requested information within [insert number of days, normally 5 working days] days of receiving such a request. Failure to provide a satisfactory response to the request for further information within the prescribed period of receiving such a request may cause the rejection of the Bid.

\section{NOTE}

The Employer should evaluate the responsiveness of the EHSMP to the requirement of the project Environmental Management Plan and other supplementary reference in Section 6, the Employer's country-specific requirement and local regulations on environmental, health and safety, and/or international good practices and outline here as the basis of evaluation. EA should seek support from the Engineer/PMC/H\&S consultant in reviewing the plan if they do not have inhouse expertise.

\subsubsection{Sustainable Procurement}

Example text: The following sustainable procurement technical requirements will be evaluated on a pass/fail basis. Failure to meet any of the following requirements will result in mandatory rejection of the bid.

[ E.g. No diesel plant is proposed for the construction process.]

\section{NOTE}

If specific sustainable procurement technical requirements have been specified in Section 6 (Employer's Requirements), either state that (i) those requirements will be evaluated on a pass/fail (compliance basis) or otherwise (ii) in addition to evaluating those requirements on a pass/fail (compliance basis), if applicable, specify the monetary adjustments to be applied to Bid prices for comparison purposes on account of Bids that exceed the specified minimum sustainable procurement technical requirements. 


\subsection{Domestic Preference}

Domestic preference will be granted to eligible domestically produced Plant and Equipment in accordance with the following provisions:

(a) The preference margin shall not be applied to the whole facility but only to the eligible domestically produced Plant and Equipment within the contract.

(b) Plant and Mandatory Spare Parts supplied from abroad shall be quoted CIP (Section 4 [Bidding Forms], Schedule No. 1). Plant and Mandatory Spare Parts supplied from within the Employer's country shall be quoted EXW (ex works, ex factory, ex warehouse, ex showroom, or off-the-shelf, as applicable) free of sales and similar taxes (Section 4 [Bidding Forms], Schedule No. 2).

(c) All other cost components for services and works, such as costs for design, local handling, transportation, storage, installation, and commissioning, shall be quoted separately. See Section 4 (Bidding Forms), Schedule No. 3 on Design Services and Schedule No. 4 on Installation and Other Services).

(d) In the comparison of Bids, only the CIP price component of each Bid for the Plant and Equipment offered from outside the Employer's country shall be increased by [insert a percentage not exceeding 15\%].

(e) No domestic preference shall be applied to any of the services or works included in the contract.

(f) Bidders shall not be permitted or required to modify the mix of local and foreign Plant and Equipment after bid opening. 


\section{Multiple Contracts}

If works are grouped in multiple contracts and pursuant to ITB 48.5, the Employer will evaluate and compare Bids on the basis of a contract, or a combination of contracts, or as a total of contracts to arrive at the least cost combination for the Employer by taking into account discounts offered by Bidders in case of award of multiple contracts.

If a Bidder as defined in ITB 4.1 submits several successful (lowest evaluated substantially responsive) Bids, the evaluation will also include an assessment of the Bidder's capacity to meet the following aggregated requirements as presented in the Bid:

- Average annual turnover,

- Financial resources,

- Equipment to be allocated, and

- Personnel to be fielded.

\section{NOTE}

The Employer shall refer to the applicable qualification requirement(s) for each contract in Part A of this section. 


\section{Section 4: Bidding Forms}

This section contains the forms to be completed by the Bidder and submitted as part of its Bid.

\section{Table of Forms}

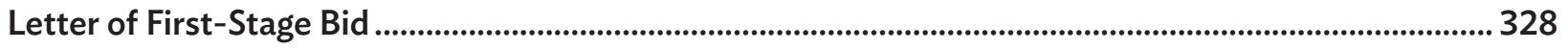

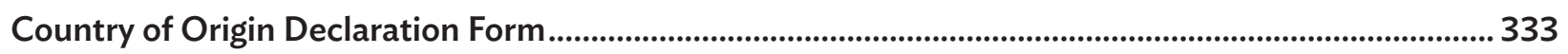

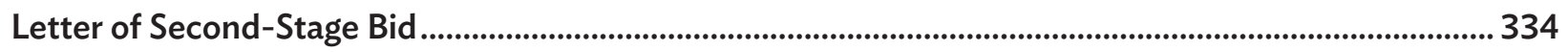

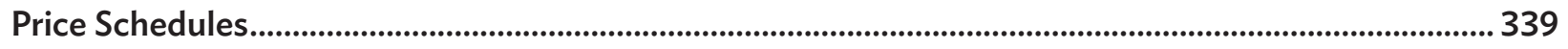

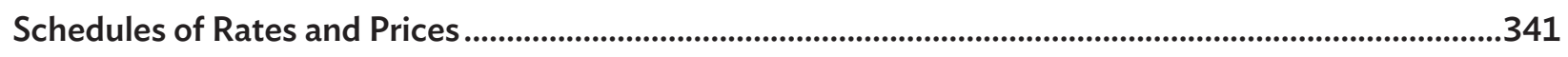

Schedule No. 1: Plant and Mandatory Spare Parts Supplied from Abroad................................................. 341

Schedule No. 2: Plant and Mandatory Spare Parts Supplied from Within the Employer's Country .... 342

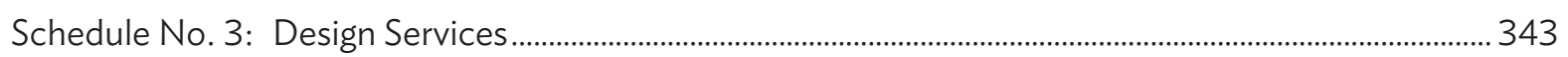

Schedule No. 4: Installation and Other Services ........................................................................................ 344

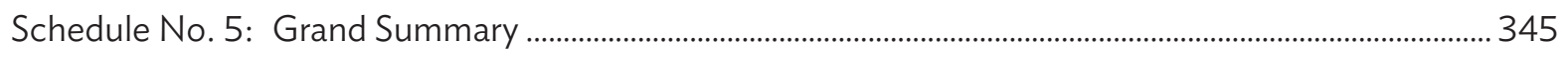

Schedule No. 6: Recommended Spare Parts............................................................................................................ 346

Tables of Adjustment Data .......................................................................................................................................... 347

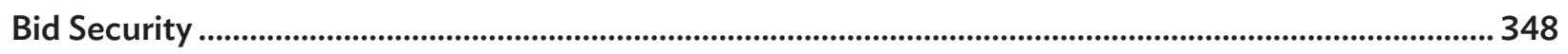

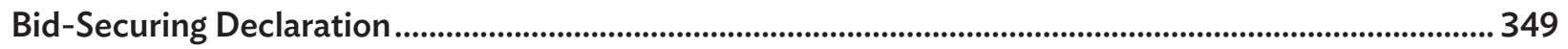

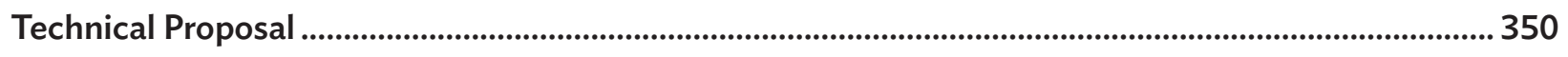

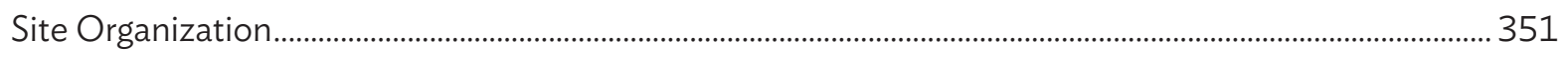

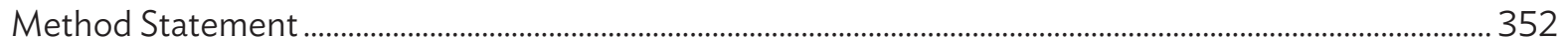

Mobilization Schedule ........................................................................................................................................... 353

Construction Schedule ...................................................................................................................................... 354

Environmental, Health and Safety Management Plan................................................................................... 354

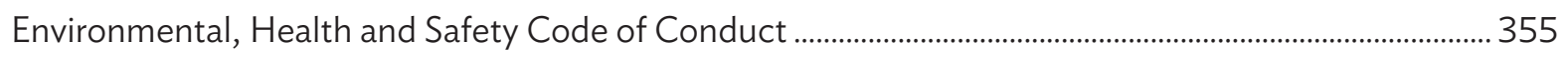

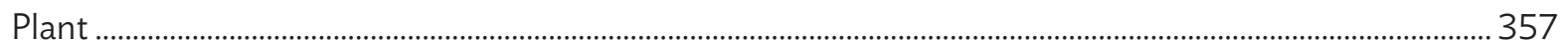




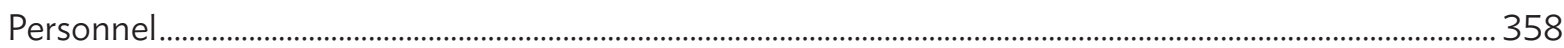

Form PER - 1: Proposed Personnel ............................................................................................................. 358

Form PER - 2: Resume of Proposed Personnel................................................................................................. 359

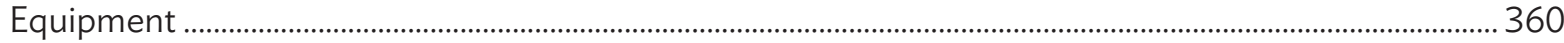

Proposed Subcontractors and/or Manufacturers for Major Items of Plant and Services ........................ 361

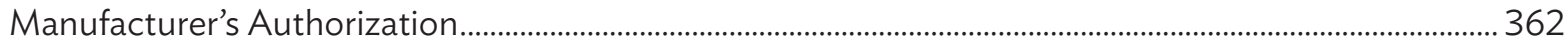

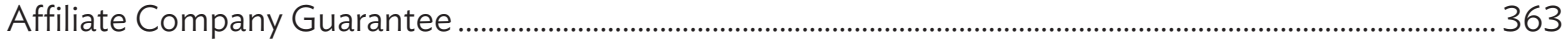

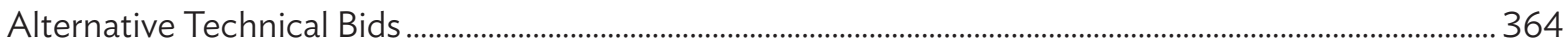

Functional Guarantee of the Proposed Facilities ............................................................................................... 365

Bidder's Qualification .............................................................................................................................................. 366

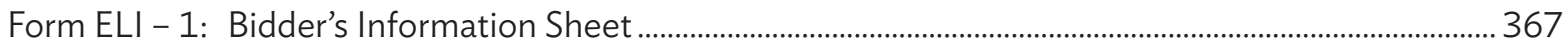

Form ELI - 2: Joint Venture Information Sheet ............................................................................................... 368

Form CON - 1: Historical Contract Nonperformance ………………………………………………............... 369

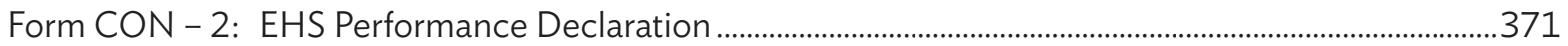

Form FIN - 1: Historical Financial Performance …………………………………........................................... 374

Form FIN - 2: Average Annual Turnover ............................................................................................................ 375

Form FIN - 3: Availability of Financial Resources ........................................................................................... 376

Form FIN - 4: Financial Requirements for Current Contract Commitments ............................................. 377

Form FIN - 5: Self-Assessment Tool for Bidder's Compliance to Financial Resources ............................. 378

Form EXP - 1: Contracts of Similar Size and Nature ................................................................................... 379

Form EXP - 2: Experience in Key Activities ..................................................................................................... 380

Form EXP - 3: Specific Experience in Managing Environmental, Health and Safety Aspects .................381

Form EXP - 4: Environmental, Health and Safety Certification........................................................................382

Form EXP - 5: Environmental, Health and Safety Documentation..............................................................383

Form EXP - 6: Environmental, Health and Safety Dedicated Personnel.........................................................384

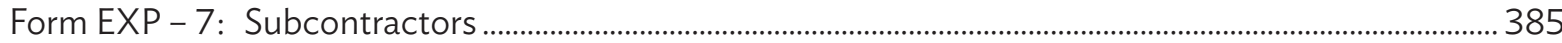




\title{
Letter of First-Stage Bid
}

\section{NOTE}

The Bidder must accomplish the Letter of First-Stage Bid on its letterhead clearly showing the Bidder's complete name and address.

\author{
Date: \\ OCB No.: \\ Invitation for Bid No.:
}

To: [insert complete name of the Employer]

We, the undersigned, declare that:

(a) We have examined and have no reservations to the Bidding Documents, including Addenda issued in accordance with Instructions to Bidders (ITB) 8.

(b) We acknowledge that we have read and understand ADB's Anticorruption Policy (1998) and Integrity Principles and Guidelines (2015), both as amended from time to time.

(c) We offer to design, manufacture, test, deliver, install, pre-commission, and commission in conformity with the Bidding Document the following Plant and Services: [insert narrative]

(d) Our firm, including any Subcontractors or Manufacturers for any part of the contract, have or will have nationalities from eligible countries, in accordance with ITB 4.2.

(e) We, our directors, key officers, key personnel, including any Subcontractor, consultants, subconsultants, manufacturers, service providers or Suppliers for any part of the contract, do not have any conflict of interest in accordance with ITB 4.3.

If there is any conflict of interest, please state details:

(i) Parties involved in the conflict of interest:

(ii) Details about the conflict of interest:

(f) We are not participating, as a Bidder, either individually or as partner in a Joint Venture, in more than one Bid in this bidding process in accordance with ITB 4.3(e), other than alternative offers submitted in accordance with ITB 13. 
(g) Our firm, Joint Venture partners, our respective direct and indirect shareholders, directors, key officers, key personnel, associates, parent company, its affiliates or subsidiaries, including any Subcontractors, consultants, subconsultants, manufacturers, service providers or Suppliers for any part of the contract, are not subject to, or not controlled by any entity or individual that is subject to, a temporary suspension or a debarment imposed by the Asian Development Bank or a debarment imposed by the Asian Development Bank in accordance with the Agreement for Mutual Enforcement of Debarment Decisions between the Asian Development Bank and other development banks. ${ }^{1}$

(h) Our firm, Joint Venture partners, our respective direct and indirect shareholders, directors, key officers, key personnel, associates, parent company, affiliates or subsidiaries, including any Subcontractors, consultants, subconsultants, manufacturers, service providers or Suppliers for any part of the contract, are not under ongoing investigation and/or sanctions proceedings by the Asian Development Bank or any multilateral development bank.

If under ongoing investigation and/or sanction proceedings by the Asian Development Bank or any multilateral development bank, please state details:

(i) Name of the multilateral development bank:

(ii) Reason for the ongoing investigation/allegations:

(i) Our firm, Joint Venture partners, our respective direct and indirect shareholders, directors, key officers, key personnel, associates, parent company, affiliates or subsidiaries, including any Subcontractors, consultants, subconsultants, manufacturers, service providers or Suppliers for any part of the Contract, are not temporarily suspended, debarred, declared ineligible, or subject to any national and/or international sanctions by any country, any international organization, any multilateral development bank and other donor agency.

If so temporarily suspended, debarred, declared ineligible, or subject to any national and/or international sanctions by any country, any international organization, any multilateral development bank and other donor agency, please state details (as applicable to each Joint Venture partner, their respective direct or indirect shareholders, directors, key officers, key personnel, associate, parent company, affiliate, subsidiaries, Subcontractors, consultants, subconsultants, manufacturers, service providers and/or Suppliers):

(i) Name of Institution:

(ii) Period of the temporary suspension, debarment, ineligibility, or national or international sanction [start and end date]:

(iii) Reason for the temporary suspension, debarment, ineligibility, or national or international sanction:

1 These institutions include African Development Bank, European Bank for Reconstruction and Development (EBRD), Inter-American Development Bank (IADB), and the World Bank Group. According to para. 9 of the Agreement, other international financial institutions may join upon the consent of all Participating Institutions and signature of a Letter of Adherence by the international financial institution substantially in the form provided (Annex B to the Agreement). Upon adherence, such international financial institution shall become a Participating Institution for purposes of the Agreement. Bidders are advised to check www.adb.org/integrity for updates. 
(j) Our firm, Joint Venture partners, associates, parent company's affiliates or subsidiaries, including any Subcontractors, consultants, subconsultants, manufacturers, service providers or Suppliers, key officers, directors and key personnel have never been charged or convicted with any criminal offense (including felonies but excluding misdemeanors) or infractions and/or violations of ordinance; nor charged or found liable in any civil or administrative proceedings in the last 10 years; or undergoing investigation for such, or subject to any criminal, civil or administrative orders, monitorship or enforcement actions.

If so charged, convicted/found liable, under ongoing investigation, or subject to orders, monitorship or enforcement actions, please state details:

(i) Nature of the offense/violation, proceedings, investigation, and/or monitorship or enforcement actions:

(ii) Court, area of jurisdiction and/or the enforcement agency:

(iii) Resolution [i.e. dismissed, settled, or convicted; duration of penalty]:

(iv) Other relevant details [please specify]:

(k) Our firm, Joint Venture partners, our respective direct and indirect shareholders, directors, key officers, key personnel, associates, affiliates or subsidiaries, including any Subcontractors, consultants, subconsultants, manufacturers, service providers or Suppliers, can make and receive electronic fund transfer payments through the international banking system or otherwise discharge the Employer's obligation upon initiation of wire transfer.

If unable to make or receive funds through the international banking system or otherwise discharge the Employer's obligation upon initiation of wire transfer, please state the details:

(i) Nature of the restriction:

(ii) Jurisdiction of the restriction:

(iii) Other relevant details:

(I) Our firm, Joint Venture partners, associates, parent company, affiliates or subsidiaries, including any Subcontractors, consultants, subconsultants, manufacturers, service providers or Suppliers, key officers, directors and key personnel are not from a country which is prohibited to export goods or services to, or receive any payments from the Employer's country and are not prohibited to receive payments for particular goods or services by the Employer's country by an act of compliance with a decision of the United Nations Security Council taken under Chapter VII of the Charter of the United Nations.

(m) We understand that it is our obligation to notify the Employer of any changes in connection with the matters described in paragraphs (e), (g), (h), (i), (j), (k), (I) and (n)) of this Letter of Bid. 
(n) We have paid, or intend to pay, either directly or indirectly, the following commissions, gratuities, or fees with respect to the bidding process or execution of the Contract: ${ }^{2}$

Name of Recipient

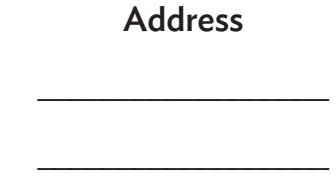

Reason

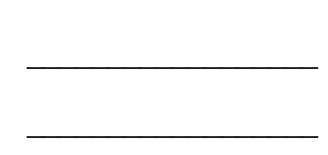

Amount

(o) [We are not a government-owned enterprise] / [We are a government-owned enterprise but meet the requirements of ITB4.5]. ${ }^{3}$

(p) We have not been suspended nor declared ineligible by the Employer based on execution of a Bid-Securing Declaration in the Employer's Country in accordance with ITB 4.6.

(q) We undertake, if invited to do so by you, and at our own cost, to attend a clarification meeting at a place of your choice, for the purpose of reviewing our First-Stage Bid and duly noting all amendments and additions thereto, and noting omissions therefrom that you may require.

(r) We further undertake, upon receiving your written invitation, to proceed with the preparation of our Second-Stage Bid, updating our First-Stage Bid in accordance with the requirements from the Memorandum "Changes Required Pursuant to First-Stage Evaluation", and completing our Second-Stage Bid for supplying the Plant and Services.

(s) At any time following submission of our Bid, we shall permit, and shall cause our Joint Venture partners, directors, key officers, key personnel, associates, parent company, affiliates or subsidiaries, including any Subcontractors, consultants, subconsultants, manufacturers, service providers or Suppliers for any part of the contract to permit ADB or its representative to inspect our site, assets, accounts and records and other documents relating to the bid submission and to have them audited by auditors appointed by $A D B$. We understand that failure of this obligation may constitute obstructive practice that may result in debarment and/or contract termination.

(t) Regardless of whether the contract will be awarded to us, we shall preserve all accounts, records and other documents related to bid submission for at least 3 years from the date of submission of the bid or the period prescribed in applicable law, whichever is longer.

(u) If we are awarded the contract, we shall preserve all accounts, records and other documents related to the procurement and execution of the contract for at least 5 years after completing the works contemplated in the relevant contracts or the period prescribed in applicable law, whichever is longer.

If none has been paid or is to be paid, indicate "None."

Use one of the two options as appropriate. 
(v) We certify on behalf of the Bidder, that the information provided in the bid has been fully reviewed, given in good faith, and to the best of our knowledge is true and complete. We understand that it is our obligation to inform the Employer of any changes to the information as and when it becomes known to us. We understand that any misrepresentation that knowingly or recklessly misleads, or attempts to mislead may lead to the automatic rejection of the Bid or cancellation of the contract, if awarded, and may result in remedial actions, in accordance with ADB's Anticorruption Policy (1998, as amended to date) and Integrity Principles and Guidelines (2015, as amended from time to time).

Name: [insert complete name of person signing the bid]

In the capacity of [insert legal capacity of person signing the bid]

Signed: [insert signature of person whose name and capacity are shown above]

Duly authorized to sign the Bid for and on behalf of [insert complete name of the Bidder]

Date: [insert date of signing] 


\section{Country of Origin Declaration Form}

Name of Bidder

IFB Number Page _- of _-

\begin{tabular}{|c|c|c|}
\hline Item & Description & Country \\
\hline & & \\
\hline & & \\
\hline & & \\
\hline & & \\
\hline
\end{tabular}




\section{Letter of Second-Stage Bid}

\section{NOTE}

The Bidder must accomplish the Letter of Second-Stage Bid on its letterhead clearly showing the Bidder's complete name and address.

To: [insert complete name of the Employer]

We, the undersigned, declare that:

(a) We have examined and have no reservations to the Bidding Document, including Addenda issued in accordance with Instructions to Bidders (ITB) 8, and your requirements incorporated in the Memorandum "Changes Required Pursuant to First-Stage Evaluation" issued after the clarification meeting held between us on [insert date].

(b) We acknowledge that we have read and understand ADB's Anticorruption Policy (1998) and Integrity Principles and Guidelines (2015), both as amended from time to time.

(c) We offer to design, manufacture, test, deliver, install, pre-commission, and commission in conformity with the Bidding Document the following Plant and Services: [insert narrative]

(d) The total price of our Bid, excluding any discounts offered in item (d) below is the sum of

[amount of foreign currency in words], [amount in figures], and [amount of local currency in words], [amount in figures]

The total bid price from the grand summary (Schedule No. 5) should be entered by the Bidder inside this box. Absence of the total bid price in the Letter of Second-Stage Bid may result in rejection of the bid.

(e) The discounts offered and the methodology for their application are as follows: [insert discounts and methodology for their application, if any]

(f) Our bid shall be valid for a period of [insert bid validity period as specified in ITB 33.1 of the BDS] days starts from the date fixed for the submission deadline for the Second-Stage bids as stipulated in the Letter of Invitation to submit a Second-Stage Bid, and it shall remain binding upon us and may be accepted at any time before the expiration of that period.

(g) If our bid is accepted, we commit to obtain a performance security in accordance with the Bidding Document. 
(h) Our firm, including any Subcontractors or Manufacturers for any part of the Contract, have or will have nationalities from eligible countries, in accordance with ITB 4.2.

(i) We, our directors, key officers, key personnel, including any Subcontractor, consultants, subconsultants, manufacturers, service providers or Suppliers for any part of the contract, do not have any conflict of interest in accordance with ITB 4.3.

If there is any conflict of interest, please state details:

(i) Parties involved in the conflict of interest:

(ii) Details about the conflict of interest:

(j) We are not participating, as a Bidder, either individually or as a partner in a Joint Venture, in more than one bid in this bidding process in accordance with ITB 4.3(e), other than alternative offers submitted in accordance with ITB 13.

(k) Our firm, Joint Venture partners, our respective direct and indirect shareholders, directors, key officers, key personnel, associates, parent company, affiliates or subsidiaries, including any Subcontractors, consultants, subconsultants, manufacturers, service providers or Suppliers for any part of the contract, are not subject to, or not controlled by any entity or individual that is subject to, a temporary suspension or a debarment imposed by the Asian Development Bank in accordance with the Agreement for Mutual Enforcement of Debarment Decisions between the Asian Development Bank and other development banks. ${ }^{1}$

(I) Our firm, Joint Venture partners, our respective direct and indirect shareholders, directors, key officers, key personnel, associates, parent company, affiliates or subsidiaries, including any Subcontractors, consultants, subconsultants, manufacturers, service providers or Suppliers for any part of the contract, are not under ongoing investigation and/or sanctions proceedings by the Asian Development Bank or any multilateral development bank.

If under ongoing investigation and/or sanction proceedings by the Asian Development Bank or any multilateral development bank, please state details:

(i) Name of multilateral development bank:

(ii) Reason for the ongoing investigation /allegations:

(m) Our firm, Joint Venture partners, our respective direct and indirect shareholders, directors, key officers, key personnel, associates, parent company, affiliates or subsidiaries, including any Subcontractors, consultants, subconsultants, manufacturers, service providers or Suppliers for any part of the Contract, are not temporarily suspended, debarred, declared ineligible, or subject to any national and/or international sanctions by any country, any international organization, any multilateral development bank and other donor agency.

1 These institutions include African Development Bank, European Bank for Reconstruction and Development (EBRD), Inter-American Development Bank (IADB), and the World Bank Group. According to para. 9 of the Agreement, other international financial institutions may join upon the consent of all Participating Institutions and signature of a Letter of Adherence by the international financial institution substantially in the form provided (Annex B to the Agreement). Upon adherence, such international financial institution shall become a Participating Institution for purposes of the Agreement. Bidders are advised to check www.adb.org/integrity for updates. 
If so temporarily suspended, debarred, declared ineligible, or, subject to any national and/or international sanctions by any country, any international organization, any multilateral development bank and other donor agency, please state details (as applicable to each Joint Venture partner, their respective direct ot indirect shareholders, directors, key officers, key personnel, associate, parent company, affiliate, subsidiaries, Subcontractors, consultants, subconsultants, manufacturers, service providers and/or Suppliers):

(i) Name of Institution:

(ii) Period of the temporary suspension, debarment, ineligibility, or national or international sanction [start and end date]:

(iii) Reason for the temporary suspension, debarment, ineligibility, or national or international sanction:

(n) Our firm, Joint Venture partners, associates, parent company affiliates or subsidiaries, including any Subcontractors, consultants, subconsultants, manufacturers, service providers, Suppliers, key officers, directors and key personnel have never been charged or convicted with any criminal offense (including felonies but excluding misdemeanors) or infractions and/or violations of ordinance; nor charged or found liable in any civil or administrative proceedings in the last 10 years; or undergoing investigation for such, or subject to any criminal, civil or administrative orders, monitorship or enforcement actions.

If so charged, convicted/found liable, under ongoing investigation, or subject to orders, monitorship or enforcement actions, please state details:

(i) Nature of the offense/violation, proceedings, investigation, and/or monitorship or enforcement actions:

(ii) Court, area of jurisdiction and/or the enforcement agency:

(iii) Resolution [i.e. dismissed, settled, or convicted; duration of penalty]:

(iv) Other relevant details [please specify]:

(o) Our firm, Joint Venture partners, our respective direct and indirect shareholders, directors, key officers, key personnel, associates, affiliates or subsidiaries, including any Subcontractors, consultants, subconsultants, manufacturers, service providers or Suppliers, can make and receive electronic fund transfer payments through the international banking system or otherwise discharge the Employer's obligation upon initiation of wire transfer.

If unable to make or receive funds through the international banking system or otherwise discharge the Employer's obligation upon initiation of wire transfer, please state the details:

(i) Nature of the restriction:

(ii) Jurisdiction of the restriction:

(iii) Other relevant details:

(p) Our firm, Joint Venture partners, associates, parent company, affiliates or subsidiaries, including any Subcontractors, consultants, subconsultants, manufacturers, service providers or Suppliers, key officers, directors and key personnel are not from a country which is prohibited to export goods or services to, or receive any payments from the Employer's country and/or are not prohibited to receive payments for particular goods or services by the Employer's country by an act of compliance with a decision of the United Nations Security Council taken under Chapter VII of the Charter of the United Nations. 
(q) [We are not a government-owned enterprise] / [We are a government-owned enterprise but meet the requirements of ITB 4.5 $]^{2}$

(r) We have paid, or intend to pay, either directly or indirectly, the following commissions, gratuities, or fees with respect to the bidding process or execution of the Contract: ${ }^{3}$

\section{Name of Recipient}

Address

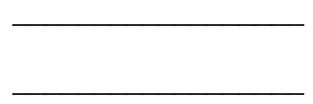

Reason

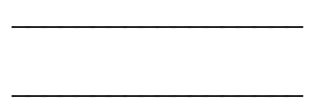

Amount

(s) We understand that it is our obligation to notify the Employer of any changes in connection with the matters described in paragraphs (i), (k), (I), (m), (n), (o), (p) and (r) of this Letter of Second-Stage Bid.

(t) We understand that this Bid, together with your written acceptance thereof included in your notification of award through the issuance of Letter of Acceptance, shall constitute a binding contract between us, until a formal contract is prepared and executed.

(u) At any time following submission of our Bid, we shall permit, and shall cause our Joint Venture partners, directors, key officers, key personnel, associates, parent company, affiliates or subsidiaries, including any Subcontractors, consultants, subconsultants, manufacturers, service providers or Suppliers for any part of the contract to permit ADB or its representative to inspect our site, assets, accounts and records and other documents relating to the bid submission and to have them audited by auditors appointed by ADB. We understand that failure of this obligation may constitute obstructive practice that may result in debarment and/or contract termination.

(v) Regardless of whether the contract will be awarded to us, we shall preserve all accounts, records and other documents related to bid submission for at least 3 years from the date of submission of the bid or the period prescribed in applicable law, whichever is longer.

(w) If we are awarded the contract, we shall preserve all accounts, records and other documents related to the procurement and execution of the contract for at least 5 years after completing the works contemplated in the relevant contracts or the period prescribed in applicable law, whichever is longer.

(x) We understand that you are not bound to accept the lowest evaluated bid or any other bid that you may receive.

(y) If our Bid is accepted, we commit to mobilizing key equipment and personnel in accordance with the requirements set forth in Section 6 (Employer's Requirements) and our technical proposal, or as otherwise agreed with the Employer.

Use one of the two options as appropriate.

If none has been paid or is to be paid, indicate "None." 
(z) We certify on behalf of the Bidder, that the information provided in the bid has been fully reviewed, given in good faith, and to the best of our knowledge is true and complete. We understand that it is our obligation to inform the Employer of any changes to the information as and when it becomes known to us. We understand that any misrepresentation that knowingly or recklessly misleads, or attempts to mislead may lead to the automatic rejection of the Bid or cancellation of the contract, if awarded, and may result in remedial actions, in accordance with ADB's Anticorruption Policy (1998, as amended to date) and Integrity Principles and Guidelines (2015, as amended from time to time).

(aa) We confirm and stand by our commitments and other declarations made in connection with the submission of our Letter of First-Stage Bid.

Name: [insert complete name of person signing the bid]

In the capacity of [insert legal capacity of person signing the bid]

Signed: [insert signature of person whose name and capacity are shown above]

Duly authorized to sign the Bid for and on behalf of [insert complete name of the Bidder]

Date: [insert date of signing] 


\section{Price Schedules}

\section{NOTES}

To receive consistent and responsive bids, it is recommended that Employers include a Preamble to the price schedules, indicating exactly what is required of Bidders when completing and pricing their bids.

The following Preamble is given as an example only. Employers are responsible for ensuring that the Preamble included in the bidding document is complete and appropriate for the contract in question.

\section{PREAMBLE}

\section{General}

1. The Price Schedules are divided into separate Schedules as follows:

Schedule No. 1: Plant and Mandatory Spare Parts Supplied from Abroad

Schedule No. 2: Plant and Mandatory Spare Parts Supplied from Within the Employer's Country

Schedule No. 3: Design Services

Schedule No. 4: Installation and Other Services

Schedule No. 5: Grand Summary

Schedule No. 6: Recommended Spare Parts

2. The Schedules do not generally give a full description of the plant to be supplied and the services to be performed under each item. Bidders shall be deemed to have read the Employer's Requirements and other sections of the Bidding Document and reviewed the drawings to ascertain the full scope of the requirements included in each item prior to filling in the rates and prices. The entered rates and prices shall be deemed to cover the full scope as aforesaid, including overheads and profit.

3. If Bidders are unclear or uncertain as to the scope of any item, they shall seek clarification in accordance with ITB 7 prior to submitting their bid.

\section{Pricing}

4. The units and rates in figures entered into the Price Schedules should be typewritten or if written by hand, must be in print form. Price Schedules not presented accordingly may be considered nonresponsive. Any alterations necessary due to errors, etc., shall be initialed by the Bidder.

As specified in the Bid Data Sheet and Special Conditions of Contract, prices shall be fixed and firm for the duration of the Contract, or prices shall be subject to adjustment in accordance with the corresponding Appendix (Price Adjustment) to the Contract Agreement.

5. Bid prices shall be quoted in the manner indicated and in the currencies specified in the Instructions to Bidders in the Bidding Document.

For each item, Bidders shall complete each appropriate column in the respective Schedules, giving the price breakdown as indicated in the Schedules. 
Prices given in the Schedules against each item shall be for the scope covered by that item as detailed in Section 6 (Employer's Requirements) or elsewhere in the Bidding Document.

6. Payments will be made to the Contractor in the currency or currencies indicated under each respective item.

7. When requested by the Employer for the purposes of making payments or part payments, valuing variations or evaluating claims, or for such other purposes as the Employer may reasonably require, the Contractor shall provide the Employer with a breakdown of any composite or lump sum items included in the Schedules. 


\section{Schedules of Rates and Prices}

Schedule No. 1: Plant and Mandatory Spare Parts Supplied from Abroad

\begin{tabular}{|c|c|c|c|c|c|c|c|}
\hline \multirow[b]{2}{*}{ Item } & \multirow[b]{2}{*}{ Description } & \multirow[b]{2}{*}{$\begin{array}{l}\text { Country } \\
\text { of Origin }\end{array}$} & \multirow[b]{2}{*}{ Quantity } & \multicolumn{2}{|c|}{ Unit Price $^{a}$} & \multirow{2}{*}{$\begin{array}{c}\text { Total Price }^{\mathrm{a}} \\
\begin{array}{c}\text { Foreign } \\
\text { Currency }\end{array}\end{array}$} & \multirow{2}{*}{$\begin{array}{c}\begin{array}{c}\text { Taxes and } \\
\text { Duties }\end{array} \\
\begin{array}{c}\text { Local } \\
\text { Currency }\end{array}\end{array}$} \\
\hline & & & & $\begin{array}{l}\text { Foreign } \\
\text { Currency }\end{array}$ & CIP & & \\
\hline 1 & 2 & 3 & 4 & 5 & 6 & $7=4 \times 6$ & 8 \\
\hline & & & & & & & \\
\hline & & & & & & & \\
\hline & & & & & & & \\
\hline & & & & & & & \\
\hline & & & & & & & \\
\hline & & & & & & & \\
\hline & & & & & & & \\
\hline & Column 7 & Irried for & to Scho & $\mathrm{Ne} 5 . \mathrm{Gr}$ & & & \\
\hline
\end{tabular}

a Specify currencies in accordance with ITB 32.1 of the BDS. Create additional columns for foreign currencies if so required.

Name of Bidder

Signature of Bidder

Country of Origin Declaration Form

\begin{tabular}{|l|l|l|}
\hline Item & Description & Country \\
\hline & & \\
\hline & & \\
\hline & & \\
\hline & & \\
\hline
\end{tabular}


Schedule No. 2: Plant and Mandatory Spare Parts Supplied from Within the Employer's Country

\begin{tabular}{|c|c|c|c|c|c|c|}
\hline \multirow[b]{2}{*}{ Item } & \multirow[b]{2}{*}{ Description } & \multirow[b]{2}{*}{ Quantity } & \multicolumn{2}{|c|}{ Unit Price $^{a}$} & \multirow[b]{2}{*}{$\begin{array}{c}\text { Total EXW } \\
\text { Price }^{\mathrm{a}}\end{array}$} & \multirow[b]{2}{*}{$\begin{array}{l}\text { Sales and } \\
\text { other taxes }\end{array}$} \\
\hline & & & $\begin{array}{l}\text { Local } \\
\text { Currency }\end{array}$ & EXW Price ${ }^{b}$ & & \\
\hline 1 & 2 & 3 & 4 & 5 & $6=3 \times 5$ & 7 \\
\hline & & & & & & \\
\hline & & & & & & \\
\hline & & & & & & \\
\hline & & & & & & \\
\hline & & & & & & \\
\hline & & & & & & \\
\hline & & & & & & \\
\hline & & & & & & \\
\hline & & & & & & \\
\hline & & & & & & \\
\hline & & & & & & \\
\hline & & & & & & \\
\hline & & & & & & \\
\hline & & & & & & \\
\hline & ancto & c & - & & & \\
\hline
\end{tabular}

a Specify currency in accordance with ITB 32.1 of the BDS.

b Column 5, EXW Price shall include all customs duties and sales and other taxes already paid or payable on the components and raw materials used in the manufacture or assembly of the item or the customs duties and sales and other taxes already paid on previously imported items.

Name of Bidder

Signature of Bidder 
Schedule No. 3: Design Services

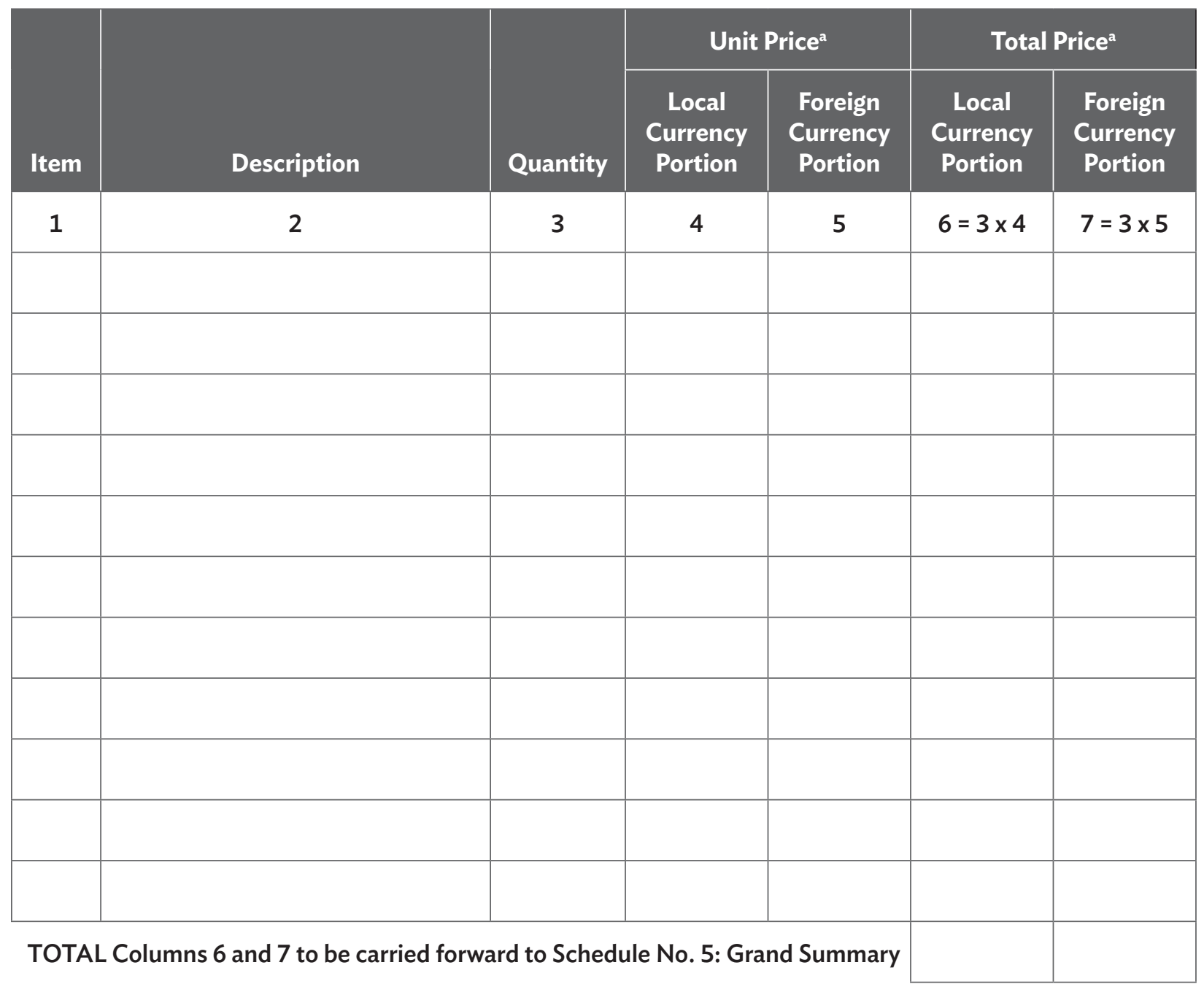

a Specify currency in accordance with ITB 32.1 of the BDS.

Name of Bidder

Signature of Bidder 
Schedule No. 4: Installation and Other Services

\begin{tabular}{|c|c|c|c|c|c|c|}
\hline \multirow[b]{2}{*}{ Item } & \multirow[b]{2}{*}{ Description } & \multirow[b]{2}{*}{ Quantity } & \multicolumn{2}{|c|}{ Unit Price $^{\mathrm{a}}$} & \multicolumn{2}{|c|}{ Total Price ${ }^{\mathrm{a}}$} \\
\hline & & & $\begin{array}{l}\text { Local } \\
\text { Currency } \\
\text { Portion }\end{array}$ & $\begin{array}{l}\text { Foreign } \\
\text { Currency } \\
\text { Portion }\end{array}$ & $\begin{array}{l}\text { Local } \\
\text { Currency } \\
\text { Portion }\end{array}$ & $\begin{array}{l}\text { Foreign } \\
\text { Currency } \\
\text { Portion }\end{array}$ \\
\hline 1 & 2 & 3 & 4 & 5 & $6=3 \times 4$ & $7=3 \times 5$ \\
\hline 1 & $\ldots \ldots$ & & & & & \\
\hline 2 & $\ldots \ldots$ & & & & & \\
\hline 3 & $\ldots \ldots$ & & & & & \\
\hline 4 & $\ldots \ldots$ & & & & & \\
\hline 5 & $\ldots \ldots$ & & & & & \\
\hline 6 & $\begin{array}{l}\text { STI/STD and HIV/AIDS alleviation } \\
\text { program }^{b}\end{array}$ & & & & & \\
\hline etc. & $\ldots \ldots$ & & & & & \\
\hline & & & & & & \\
\hline & & & & & & \\
\hline & & & & & & \\
\hline TOT & AL Columns 6 and 7 to be carried fo & At to Sched & 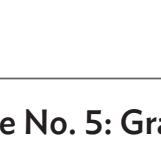 & & & \\
\hline
\end{tabular}

a Specify currency in accordance with ITB 32.1 of the BDS.

${ }^{b}$ As described in SCC 22.2.7.

Name of Bidder

Signature of Bidder 
Schedule No. 5: Grand Summary

\begin{tabular}{|c|c|c|c|}
\hline \multirow{2}{*}{$\begin{array}{l}\text { Schedule } \\
\text { No. }\end{array}$} & \multirow[b]{2}{*}{ Title } & \multicolumn{2}{|c|}{ Total Price ${ }^{a}$} \\
\hline & & Foreign & Local \\
\hline 1 & Plant and Mandatory Spare Parts Supplied from Abroad ${ }^{b}$ & & \\
\hline 2 & $\begin{array}{l}\text { Plant and Mandatory Spare Parts Supplied from Within } \\
\text { the Employer's Country }{ }^{\mathrm{b}}\end{array}$ & & \\
\hline 3 & Design Services & & \\
\hline 4 & Installation and Other Services & & \\
\hline & $\begin{array}{l}\text { Grand Total to be carried forward to } \\
\text { Letter of Second-Stage Bid }\end{array}$ & & \\
\hline
\end{tabular}

a Specify currency in accordance with ITB 32.1 of the BDS. Create additional columns for as many foreign currencies as required.

b Taxes and/or duties from Schedules 1 and 2 may be added to the contract price in accordance with GCC 14 (Taxes and Duties) but are excluded from bid evaluation in accordance with ITB 48.3.

Name of Bidder

Signature of Bidder 
Schedule No. 6: Recommended Spare Parts

\begin{tabular}{|c|c|c|c|c|c|c|}
\hline \multirow[b]{2}{*}{ Item } & \multirow[b]{2}{*}{ Description } & \multirow[b]{2}{*}{ Quantity } & \multicolumn{2}{|c|}{ Unit Price } & \multicolumn{2}{|c|}{ Total Price } \\
\hline & & & $\begin{array}{l}\text { EXW } \\
\text { Local } \\
\text { Parts } \\
\text { Local } \\
\text { Currency }\end{array}$ & $\begin{array}{c}\text { CIP } \\
\text { Imported } \\
\text { Parts } \\
\text { Foreign } \\
\text { Currency }\end{array}$ & $\begin{array}{l}\text { Local } \\
\text { Currency } \\
\text { Portion }\end{array}$ & $\begin{array}{l}\text { Foreign } \\
\text { Currency } \\
\text { Portion }\end{array}$ \\
\hline 1 & 2 & 3 & 4 & 5 & $6=3 \times 4$ & $7=3 \times 5$ \\
\hline & & & & & & \\
\hline & & & & & & \\
\hline & & & & & & \\
\hline & & & & & & \\
\hline & & & & & & \\
\hline & & & & & & \\
\hline & & & & & & \\
\hline & & & & & & \\
\hline & & & & & & \\
\hline & & & & & & \\
\hline & & & & & & \\
\hline & & & & TOTAL & & \\
\hline
\end{tabular}

a Specify currency in accordance with ITB 32.1 of the BDS.

Name of Bidder

Signature of Bidder 


\section{Tables of Adjustment Data}

Table A - Local Currency

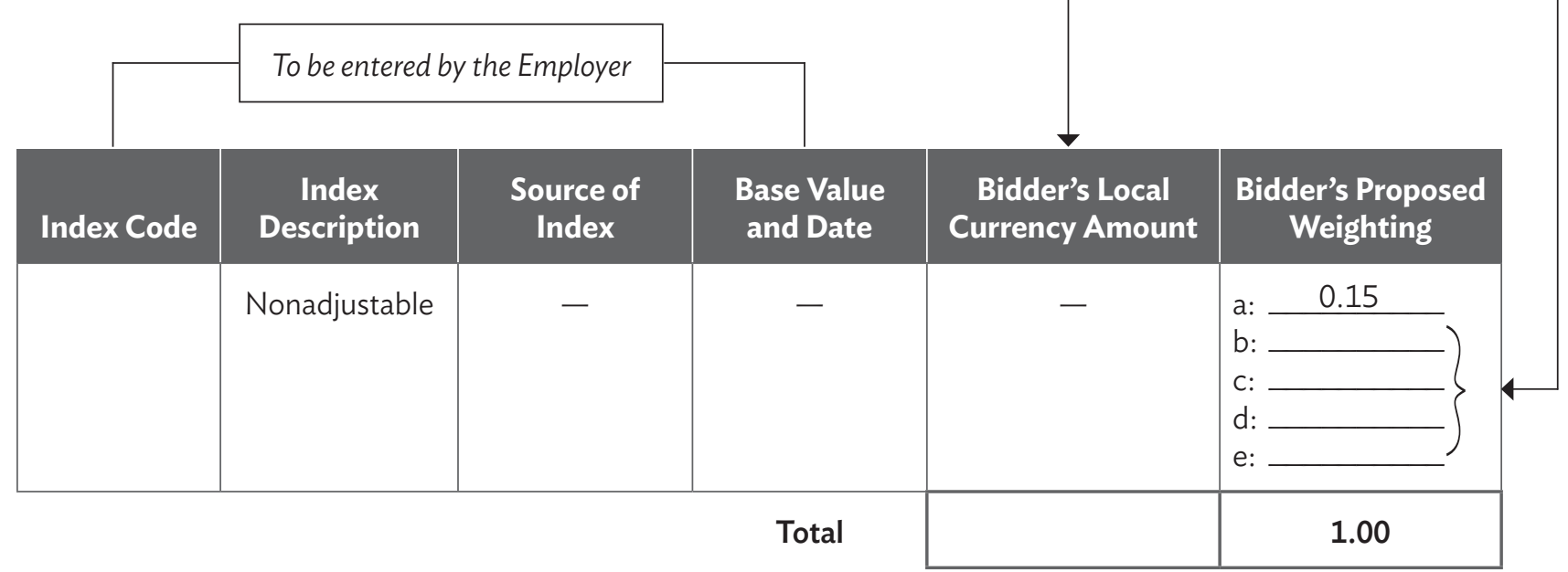

\section{Table B - Foreign Currency}

Name of Currency: [Insert name of currency. If the Bidder wishes to quote in more than one foreign currency, this table should be repeated for each foreign currency]

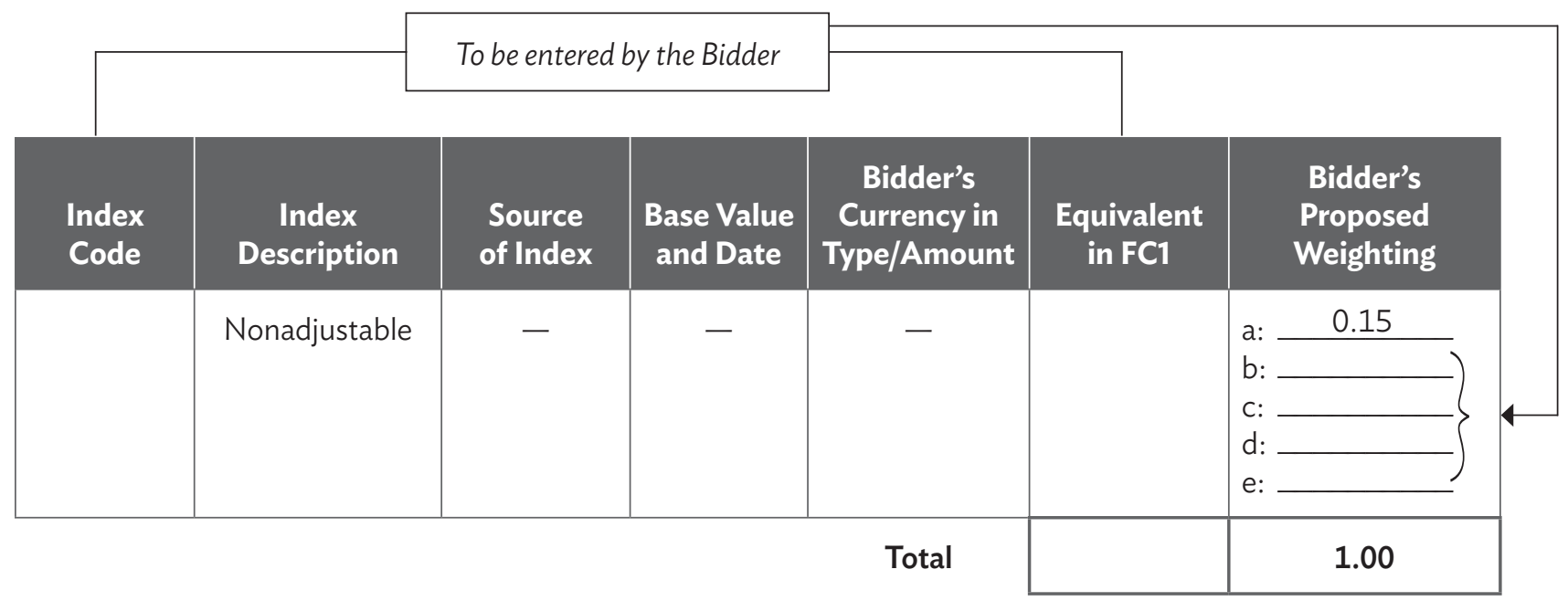

\section{NOTES}

The base date shall be the date 28 days prior to the deadline for submission of the bid.

Tables of Adjustment Data shall only be included if prices are to be quoted as adjustable prices in accordance with ITB 31.6. 


\section{Bid Security}

\section{Bank Guarantee}

[insert bank's name, and address of issuing branch or office $]^{1}$

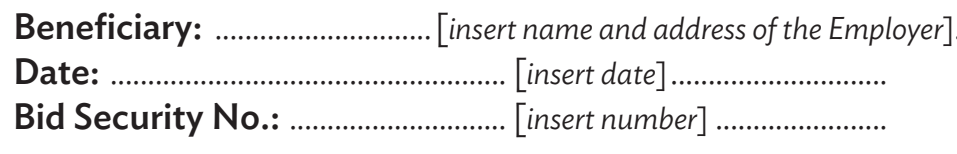

We have been informed that [insert name of the Bidder]. (hereinafter called "the Bidder") has submitted to you its Bid dated [insert date] (hereinafter called "the Bid") for the execution of [insert name of contract] under Invitation for Bids No. [insert IFB number] ("the IFB").

Furthermore, we understand that, according to your conditions, bids must be supported by a bid guarantee.

At the request of the Bidder, we [insert name of bank] hereby irrevocably undertake to pay you any sum or sums not exceeding in total an amount of [insert amount in words] [insert amount in figures] upon receipt by us of your first demand in writing accompanied by a written statement, stating that the Bidder is in breach of its obligation(s) under the bid conditions, because the Bidder

a) has withdrawn its Bid during the period of bid validity specified by the Bidder in the Letter of Second-Stage Bid; or

b) does not accept the correction of errors in accordance with the Instruction to Bidders (hereinafter "the ITB"); or

c) having been notified of the acceptance of its Bid by the Employer during the period of bid validity, (i) fails or refuses to execute the Contract Agreement, or (ii) fails or refuses to furnish the Performance Security, in accordance with the ITB.

This guarantee will expire (a) if the Bidder is the successful Bidder, upon our receipt of copies of the Contract Agreement signed by the Bidder and the Performance Security issued to you upon the instruction of the Bidder; or (b) if the Bidder is not the successful Bidder, upon the earlier of (i) our receipt of a copy of your notification to the Bidder of the name of the successful Bidder, or (ii) 28 days after the expiration of the Bidder's bid.

Consequently, any demand for payment under this guarantee must be received by us at the office indicated above on or before that date.

This guarantee is subject to the Uniform Rules for Demand Guarantees (URDG) 2010 Revision, ICC Publication No. $758 .^{2}$

[Authorized signature(s) and bank's seal (where appropriate)]

All italicized text is for use in preparing this form and shall be deleted from the final document.

Or the employer may use "Uniform Rules for Demand Guarantees (URDG), ICC Publication No. 458" as appropriate. 


\section{Bid-Securing Declaration}

Date: [insert date (as day, month, and year)]

Bid No.: [insert number of bidding process]

Alternative No.: [insert identification no. if this is a bid for an alternative]

To: [insert complete name of the Employer]

We, the undersigned, declare that:

We understand that, according to your conditions, bids must be supported by a Bid-Securing Declaration.

We accept that we will automatically be suspended from being eligible for bidding in any contract with the Borrower for the period of time of [insert number of years as indicated in ITB 34.2 of the BDS] starting on the date that we receive a notification from the Employer, if we are in breach of our obligation(s) under the bid conditions, because we

(a) have withdrawn our Bid during the period of bid validity specified in the Letter of Second-Stage Bid; or

(b) do not accept the correction of errors in accordance with the Instructions to Bidders (hereinafter "the ITB"); or

(c) having been notified of the acceptance of our Bid by the Employer during the period of bid validity, (i) fail or refuse to execute the Contract, if required; or (ii) fail or refuse to furnish the Performance Security, in accordance with the ITB.

We understand that this Bid-Securing Declaration shall expire if we are not the successful Bidder, upon the earlier of (i) our receipt of your notification to us of the name of the successful Bidder; or (ii) 28 days after the expiration of our Bid.

Signed: [insert signature of person whose name and capacity are shown]

In the capacity of [insert legal capacity of person signing the bid-securing declaration]

Name: [insert complete name of person signing the bid-securing declaration]

Duly authorized to sign the bid for and on behalf of [insert complete name of the Bidder]

Dated on day of [insert date of signing]

Corporate Seal [where appropriate] 


\section{Technical Proposal}

Site Organization

Method Statement

Mobilization Schedule

Construction Schedule

Environmental, Health and Safety Management Plan

Environmental, Health and Safety Code of Conduct

Plant

Personnel

Equipment

Proposed Subcontractors for Major Items of Plant and Services

Manufacturer's Authorization

Affiliate Company Guarantee

Alternative Technical Bids

Functional Guarantee of the Proposed Facilities 
Site Organization 
Method Statement 


\section{Mobilization Schedule}

The Mobilization Schedule should reflect the no-objection request and approval step for Site Specific Environmental, Health and Safety Management Plan as per Contract Conditions. 


\section{Construction Schedule}

The construction schedule shall include the following key milestones:

\section{Environmental, Health and Safety Management Plan (EHSMP)}

The Bidder shall submit an outline Environmental, Health and Safety Management Plan (EHSMP) commensurate with the risks and impacts of the proposed works and activities. These strategies and plans shall describe in detail the actions, materials, equipment, management processes etc. that will be implemented by the Contractor, and its subcontractors.

In developing these strategies and plans, the Bidder shall have regard to the EHS provisions of the contract and EHS risks including those as may be more fully described in Section 6 (Employer's Requirements).

\section{NOTE}

The Employer shall assess whether the proposed site organization, method statement, mobilization schedule, and construction schedule and environmental, health and safety management plan described in Section 4 (Bidding Forms) are presented in a consistent manner and comply with requirements stipulated in Section 6 (Employer's Requirements) without material deviation, reservation, or omission. 


\title{
Environmental, Health and Safety Code of Conduct
}

\author{
Environmental, Health and Safety Code of Conduct for Contractor's Personnel Form
}

\section{NOTE TO EMPLOYER}

The following minimum requirements shall not be modified. The Employer may add additional requirements to address identified issues, informed by relevant environmental, health and safety assessment.

Delete this Box prior to issuance of the bidding documents.

\section{NOTE TO BIDDER}

The minimum content of the EHS Code of Conduct form as set out by the Employer shall not be substantially modified. However, the Bidder may add requirements as appropriate, including to take into account Contract-specific issues/risks.

The Bidder shall initial and submit the EHS Code of Conduct form as part of its bid.

\section{ENVIRONMENTAL, HEALTH AND SAFETY CODE OF CONDUCT FOR CONTRACTOR'S PERSONNEL}

We are the Contractor, [enter name of Contractor]. We have signed a contract with [enter name of Employer] for [enter description of the Works]. These Works will be carried out at [enter the Site and other locations where the Works will be carried out]. Our contract requires us to implement measures to address environmental, health and safety risks related to the Works.

This EHS Code of Conduct is part of our measures to deal with environmental, health and safety risks related to the Works. It applies to all our staff, labourers and other employees at the Works Site or other places where the Works are being carried out. It also applies to the personnel of each subcontractor and any other personnel assisting us in the execution of the Works. All such persons are referred to as "Contractor's Personnel" and are subject to this EHS Code of Conduct.

This EHS Code of Conduct identifies the behavior that we require from all Contractor's Personnel.

Our workplace is an environment where unsafe, offensive, abusive or violent behavior will not be tolerated and where all persons should feel comfortable raising issues or concerns without fear of retaliation.

\section{REQUIRED CONDUCT}

Contractor's Personnel shall:

1. carry out his/her duties competently and diligently;

2. comply with this EHS Code of Conduct and all applicable laws, regulations and other requirements, including requirements to protect the health, safety and well-being of other Contractor's Personnel and any other person;

3. maintain a safe working environment including by:

a. ensuring that workplaces, machinery, equipment, and processes under each person's control are safe and without risk to health; 
b. wearing required personal protective equipment;

c. using appropriate measures relating to chemical, physical and biological substances and agents; and

d. following applicable emergency operating procedures.

4. report work situations that he/she believes are not safe or healthy and remove himself/herself from a work situation which he/she reasonably believes presents an imminent and serious danger to his/her life or health;

5. treat other people with respect, and not discriminate against specific groups such as women, people with disabilities, migrant workers, or children;

6. report violations of this EHS Code of Conduct; and

7. not retaliate against any person who reports violations of this EHS Code of Conduct, whether to us or the Employer, or who makes use of the grievance mechanism for Contractor's Personnel or the project's Grievance Redress Mechanism.

\section{RAISING CONCERNS}

If any person observes behavior that he/she believes may represent a violation of this EHS Code of Conduct, or that otherwise concerns him/her, he/she should raise the issue promptly. This can be done by call [] to reach the Contractor's hotline (if any) and leave a message.

The person's identity will be kept confidential, unless reporting of allegations is mandated by the country law. Anonymous complaints or allegations may also be submitted and will be given all due and appropriate consideration. We take seriously all reports of possible misconduct and will investigate and take appropriate action. We will provide warm referrals to service providers that may help support the person who experienced the alleged incident, as appropriate.

\section{CONSEQUENCES OF VIOLATING THE ENVIRONMENTAL, HEALTH AND SAFETY CODE OF CONDUCT}

Any violation of this EHS Code of Conduct by Contractor's Personnel may result in serious consequences, up to and including termination and possible referral to legal authorities.

\section{FOR CONTRACTOR'S PERSONNEL:}

I have received a copy of this EHS Code of Conduct written in a language that I comprehend. I understand that if I have any questions about this EHS Code of Conduct, I can contact [enter name of Contractor's contact person(s) with relevant experience] requesting an explanation.

Name of Contractor's Personnel: [insert name]

Signature:

Date: (day month year):

Countersignature of authorized representative of the Contractor:

Signature:

Date: (day month year): 
Plant 


\section{Personnel}

\section{Form PER - 1: Proposed Personnel}

Bidders should provide the details of proposed personnel and their experience record in the relevant Information Forms below for each of the candidate.

\begin{tabular}{|l|l|}
\hline \multirow{2}{*}{1.} & Title of position \\
\cline { 2 - 2 } & Name \\
\hline \multirow{2}{*}{2.} & Title of position \\
\cline { 2 - 2 } & Name \\
\hline 3. & Title of position \\
\cline { 2 - 2 } & Name \\
\hline 4. & Title of position \\
\cline { 2 - 2 } & Name \\
\hline
\end{tabular}

Note: All titles of positions will be as listed in Section 6 (Employer's Requirements). 
Form PER - 2: Resumé of Proposed Personnel

The Bidder shall provide all the information requested below. Use one form for each position.

\begin{tabular}{|c|c|c|}
\hline \multicolumn{3}{|l|}{ Position } \\
\hline \multirow{5}{*}{$\begin{array}{l}\text { Personnel } \\
\text { information }\end{array}$} & Full Legal Name & Date of Birth \\
\hline & Known as & Place of Birth \\
\hline & Nationality & Citizenship \\
\hline & $\begin{array}{l}\text { Type of government ID } \\
\text { Attach a copy of ID to this form }\end{array}$ & ID number \\
\hline & Professional qualifications & \\
\hline \multirow{5}{*}{$\begin{array}{l}\text { Present } \\
\text { employment }\end{array}$} & \multicolumn{2}{|l|}{ Name of employer } \\
\hline & \multicolumn{2}{|l|}{ Address of employer } \\
\hline & Telephone & Contact (manager/personnel officer) \\
\hline & Fax & E-mail \\
\hline & Job title & Years with present employer \\
\hline
\end{tabular}

Summarize professional experience in reverse chronological order. Indicate particular technical and managerial experience relevant to the project.

\begin{tabular}{|l|l|l|}
\hline From & To & Company/Project/Position/Relevant Technical and Management Experience \\
\hline & & \\
\hline & & \\
\hline & & \\
\hline & & \\
\hline & & \\
\hline & & \\
\hline
\end{tabular}




\section{Equipment}

\section{Form EQU: Equipment}

The Bidder shall provide adequate information and details to demonstrate clearly that it has the capability to meet the equipment requirements indicated in Section 6 (Employer's Requirements), using the Forms below. A separate Form shall be prepared for each item of equipment listed, or for alternative equipment proposed by the Bidder.

\begin{tabular}{|l|l|l|}
\hline \multicolumn{2}{|l|}{ Item of Equipment } \\
\hline $\begin{array}{l}\text { Equipment } \\
\text { Information }\end{array}$ & Name of manufacturer & Model and power rating \\
\cline { 2 - 3 } & Capacity & Year of manufacture \\
\hline $\begin{array}{l}\text { Current } \\
\text { Status }\end{array}$ & Current location \\
\cline { 2 - 3 } & Details of current commitments \\
\hline Source & $\begin{array}{l}\text { Indicate source of the equipment } \\
\square \text { Owned } \square \text { Rented } \square \text { Leased } \quad \square \text { Specially manufactured }\end{array}$ \\
\hline
\end{tabular}

Omit the following information for equipment owned by the Bidder.

\begin{tabular}{|c|c|c|}
\hline \multirow[t]{4}{*}{ Owner } & \multicolumn{2}{|c|}{ Name of owner } \\
\hline & \multicolumn{2}{|c|}{ Address of owner } \\
\hline & Telephone & Contact name and title \\
\hline & Fax & Telex \\
\hline Agreements & \multicolumn{2}{|c|}{ Details of rental/lease/manufacture agreements specific to the project } \\
\hline
\end{tabular}




\section{Proposed Subcontractors and/or Manufacturers for Major ltems of Plant and Services}

The following Subcontractors and/or Manufacturers are proposed for carrying out the item of the facilities indicated based on Criterion 2.5 of Section 3 (Evaluation and Qualification Criteria). Bidders are free to propose more than one for each item.

\begin{tabular}{|l|c|c|}
\hline Major Items of Plant and Services & $\begin{array}{c}\text { Proposed Subcontractors and/or } \\
\text { Manufacturers }\end{array}$ & Nationality \\
\hline & & \\
& & \\
\hline
\end{tabular}




\section{Manufacturer's Authorization}

Date: [insert date (as day, month, and year) of bid submission]

OCB No.: [insert number of bidding process]

To: [insert complete name of the Employer]

\section{WHEREAS}

We [insert complete name of the manufacturer or manufacturer's authorized agent], who are official Manufacturers or agent authorized by the Manufacturer of [insert type of goods manufactured], having factories at [insert full address of manufacturer's factories], do hereby authorize [insert complete name of the bidder] to submit a Bid the purpose of which is to provide the following goods, manufactured by us [insert name and/or brief description of the goods], and to subsequently negotiate and sign the Contract.

We hereby extend our full guarantee and warranty in accordance with Clause 27 of the General Conditions of Contract, with respect to the goods offered by the above firm.

Signed: [insert signature(s) of authorized representative(s) of the manufacturer]

Name: [insert complete name(s) of authorized representative(s) of the manufacturer]

Title: [insert title]

Duly authorized to sign this Authorization on behalf of [insert complete name of the manufacturer]

Dated on day of [insert date of signing]

\section{NOTE}

The Bidder shall require the manufacturer to fill out this form in accordance with the instructions indicated. This letter of authorization should be signed by a person with the proper authority to sign documents that are binding on the manufacturer. The Bidder shall include it in its bid, if so indicated in the BDS. 


\section{Affiliate Company Guarantee}

Name of Contract/Contract No.:

Name and address of Employer:

[together with successors and assigns].

We have been informed that [name of Contractor] (hereinafter called the "Contractor") is submitting an offer for the above-referenced Contract in response to your invitation, and that the conditions of your invitation require its offer to be supported by an affiliate company guarantee.

In consideration of you, the Employer, awarding the Contract to the Contractor, we [name of affiliated company] irrevocably and unconditionally guarantee to you, as a primary obligation, that (i) throughout the duration of the Contract, we will make available to the Contractor our financial, technical capacity, expertise and resources required for the Contractor's satisfactory performance of the Contract; and (ii) we are fully committed, along with the Contractor, to ensuring a satisfactory performance of the Contract.

If the Contractor fails to so perform its obligations and liabilities and comply with the Contract, we will indemnify the Employer against and from all damages, losses and expenses (including legal fees and expenses) which arise from any such failure for which the Contractor is liable to the Employer under the Contract.

This guarantee shall come into full force and effect when the Contract comes into full force and effect. If the Contract does not come into full force and effect within a year of the date of this guarantee, or if you demonstrate that you do not intend to enter into the Contract with the Contractor, this guarantee shall be void and ineffective. This guarantee shall continue in full force and effect until all the Contractor's obligations and liabilities under the Contract have been discharged, when this guarantee shall expire and shall be returned to us, and our liability hereunder shall be discharged absolutely.

This guarantee shall apply and be supplemental to the Contract as amended or varied by the Employer and the Contractor from time to time. We hereby authorize them to agree on any such amendment or variation, the due performance of which and compliance with which by the Contractor are likewise guaranteed hereunder. Our obligations and liabilities under this guarantee shall not be discharged by any allowance of time or other indulgence whatsoever by the Employer to the Contractor, or by any variation or suspension of the works to be executed under the Contract, or by any amendments to the Contract or to the constitution of the Contractor or the Employer, or by any other matters, whether with or without our knowledge or consent.

This guarantee shall be governed by the law of the same country (or other jurisdiction) that governs the Contract and any dispute under this guarantee shall be finally settled under the [Rules or Arbitration provided in the Contract]. We confirm that the benefit of this guarantee may be assigned subject only to the provisions for assignment of the Contract.

Signed by:

[signature]

[name]

[position in parent/subsidiary company]
Signed by:

\section{[signature]}

[name]

[position in parent/subsidiary company]

Date:

\section{NOTE}

If permitted in accordance with ITB 38.2 of the BDS, the Bidder shall provide the Affiliate Company Guarantee Form filled out and signed by each subsidiary, parent entity, or affiliate that the Bidder submits for consideration of the Employer in determining its qualifications. 


\section{Alternative Technical Bids}

To be used by Bidder when alternative technical bids are invited in ITB 13. 


\section{Functional Guarantee of the Proposed Facilities}

\section{Form FUNC}

The Bidder shall copy on the left column of the table below, the identification of each functional guarantee required in the Specification and stated by the Employer in EQC 3.3 of Section 3 (Evaluation and Qualification Criteria), and on the right column, provide the corresponding value for each functional guarantee of the proposed plant and equipment.

\begin{tabular}{|l|l|}
\multicolumn{1}{c|}{$\begin{array}{c}\text { Functional Guarantee } \\
\text { [as required by the Employer in Section 3] }\end{array}$} & Functional Guarantee Value Offered by the Bidder \\
\hline 1. & \\
\hline 2. & \\
\hline 3. & \\
\hline$\ldots$ & \\
\hline
\end{tabular}




\section{Bidder's Qualification}

To establish its qualifications to perform the contract in accordance with Section 3 (Evaluation and Qualification Criteria), the Bidder shall provide the following information requested in the corresponding Information Sheets. 
Form ELI - 1: Bidder's Information Sheet

\begin{tabular}{|c|c|c|c|}
\hline \multicolumn{4}{|c|}{ Bidder's Information } \\
\hline & & $\begin{array}{l}\text { Information of } \\
\text { the Bidder }\end{array}$ & $\begin{array}{l}\text { If the Bidder is a subsidiary or branch, } \\
\text { information of any parent company/companies }\end{array}$ \\
\hline \multirow[t]{2}{*}{ Name } & Full Legal Name & & \\
\hline & $\begin{array}{l}\text { Full Trading Name(s) } \\
\text { (if any) }\end{array}$ & & \\
\hline \multirow[t]{3}{*}{ Addresses } & $\begin{array}{l}\text { Registered } \\
\text { address(es) }\end{array}$ & & \\
\hline & Trading address(es) & & \\
\hline & $\begin{array}{l}\text { Postal address(es) } \\
\text { (if different from } \\
\text { trading address) }\end{array}$ & & \\
\hline \multicolumn{2}{|c|}{ Type of organization } & & \\
\hline \multicolumn{2}{|c|}{$\begin{array}{l}\text { Country of constitution/ } \\
\text { incorporation/registration }\end{array}$} & & \\
\hline \multicolumn{2}{|c|}{$\begin{array}{l}\text { Year of constitution/incorporation/ } \\
\text { registration }\end{array}$} & & \\
\hline \multicolumn{2}{|c|}{ Corporate or registration number } & & \\
\hline \multicolumn{2}{|c|}{$\begin{array}{l}\text { In case of a Joint Venture, legal } \\
\text { name of each partner }\end{array}$} & & \\
\hline \multicolumn{2}{|c|}{$\begin{array}{l}\text { Bidder's authorized representative } \\
\text { (name, address, telephone } \\
\text { number(s), fax number(s), and } \\
\text { e-mail address) }\end{array}$} & & \\
\hline \multicolumn{4}{|c|}{ Attached are copies of the following documents: } \\
\hline \multicolumn{4}{|c|}{$\begin{array}{l}\square \text { 1. In case of a single entity, articles of incorporation or constitution and company incorporation/registration } \\
\text { of the legal entity named above, in accordance with ITB } 4.1 \text { and ITB } 4.2 \text {. }\end{array}$} \\
\hline \multicolumn{4}{|c|}{$\square$ 2. Authorization to represent the firm or Joint Venture named above, in accordance with ITB 18.2 and 35.2 . } \\
\hline \multicolumn{4}{|c|}{$\begin{array}{l}\square \text { 3. In case of a Joint venture, a let } \\
\text { in accordance with ITB 4.1. }\end{array}$} \\
\hline \multicolumn{4}{|c|}{$\begin{array}{l}\square \quad \text { 4. In case of a government-owned enterprise, any additional documents not covered under } 1 \text { above required } \\
\text { to comply with ITB 4.5. }\end{array}$} \\
\hline
\end{tabular}


Form ELI - 2: Joint Venture Information Sheet

Each partner of the Joint Venture and Specialist Subcontractor must fill out this form separately.

\begin{tabular}{|c|c|c|c|}
\hline \multicolumn{4}{|c|}{ Joint Venture/Specialist Subcontractor Information } \\
\hline \multicolumn{2}{|c|}{ Bidder's legal name } & \multirow[b]{2}{*}{$\begin{array}{l}\text { Information of Joint Venture } \\
\text { Partner or Specialist } \\
\text { Subcontractor }\end{array}$} & \multirow[b]{2}{*}{$\begin{array}{l}\text { If any Joint Venture Partner or } \\
\text { Specialist Subcontractor is a } \\
\text { subsidiary or branch, information of } \\
\text { any parent company/companies }\end{array}$} \\
\hline & & & \\
\hline \multirow[t]{2}{*}{ Names } & Full legal name(s) & & \\
\hline & $\begin{array}{l}\text { Full trading name(s) } \\
\text { (if any) }\end{array}$ & & \\
\hline \multirow[t]{3}{*}{ Addresses } & Registered address(es) & & \\
\hline & Trading address(es) & & \\
\hline & $\begin{array}{l}\text { Postal address (es) } \\
\text { (if different from } \\
\text { trading address) }\end{array}$ & & \\
\hline \multicolumn{2}{|c|}{ Type of organization } & & \\
\hline \multicolumn{2}{|c|}{$\begin{array}{l}\text { Country of constitution/ } \\
\text { incorporation/registration }\end{array}$} & & \\
\hline \multicolumn{2}{|c|}{$\begin{array}{l}\text { Year of constitution/incorporation/ } \\
\text { registration }\end{array}$} & & \\
\hline \multicolumn{2}{|c|}{ Corporate or registration number } & & \\
\hline \multicolumn{2}{|c|}{$\begin{array}{l}\text { Joint Venture Partner's or Specialist } \\
\text { Subcontractor's authorized } \\
\text { representative information } \\
\text { (name, address, telephone number(s), } \\
\text { fax number(s), and e-mail address) }\end{array}$} & & \\
\hline \multicolumn{4}{|c|}{ Attached are copies of the following documents: } \\
\hline \multicolumn{4}{|c|}{$\begin{array}{l}\square \quad \text { 1. Articles of incorporation or constitution and company incorporat } \\
\text { above, in accordance with ITB } 4.1 \text { and ITB 4.2. }\end{array}$} \\
\hline$\square$ 2. Aut & orization to represent the fi & rm named above, in accordance & ith ITB 18.2 and 35.2 . \\
\hline $\begin{array}{r}\text { 3. } \ln t \\
\text { con }\end{array}$ & $\begin{array}{l}\text { case of a government-owr } \\
\text { liance with commercial law }\end{array}$ & $\begin{array}{l}\text { ed enterprise, documents estab } \\
\text {, in accordance with ITB } 4.5 \text {. }\end{array}$ & shing legal and financial autonomy and \\
\hline
\end{tabular}

Subcontractors are those listed in Technical Proposal - Proposed Subcontractors and/or Manufacturers for Major Items of Plant and Services. 


\section{Form CON - 1: Historical Contract Nonperformance}

Each Bidder must fill out this form in accordance with Criteria 2.2.1 and 2.2.3 of Section 3 (Evaluation and Qualification Criteria) to describe any history of nonperforming contracts and pending litigation or arbitration formally commenced against it.

In case of a Joint Venture, each Joint Venture Partner must fill out this form separately and provide the Joint Venture Partner's name:

Joint Venture Partner:

\section{Table 1: History of Nonperforming Contracts}

\section{Choose one of the following:}

$\square$ No nonperforming contracts.

$\square$ Below is a description of nonperforming contracts involving the Bidder (or each Joint Venture partner if Bidder is a Joint Venture).

\begin{tabular}{|c|c|c|c|}
\hline Year & Description & $\begin{array}{l}\text { Amount of } \\
\text { Nonperformed Portion } \\
\text { of Contract } \\
\text { (\$ equivalent) }\end{array}$ & $\begin{array}{l}\text { Total Contract Amount } \\
\text { (\$ equivalent) }\end{array}$ \\
\hline $\begin{array}{l}{[\text { insert }} \\
\text { year] }\end{array}$ & $\begin{array}{l}\text { Contract Identification: [indicate complete } \\
\text { contract name/ number, and any other } \\
\text { identification] } \\
\text { Name of Employer: [insert full name] } \\
\text { Address of Employer: [insert street/city/ } \\
\text { country] } \\
\text { Reason(s) for nonperformance: [indicate } \\
\text { main reason(s)] }\end{array}$ & [insert amount] & [insert amount] \\
\hline
\end{tabular}




\section{Table 2: Pending Litigation and Arbitration}

\section{Choose one of the following:}

$\square$ No pending litigation arbitration or any other material events impacting the net worth and/or liquidity of the bidder.

$\square$ Below is a description of all pending litigation, arbitration involving the Bidder or any material events impacting the net worth and/or liquidity of the bidder (or each Joint Venture partner if Bidder is a Joint Venture).

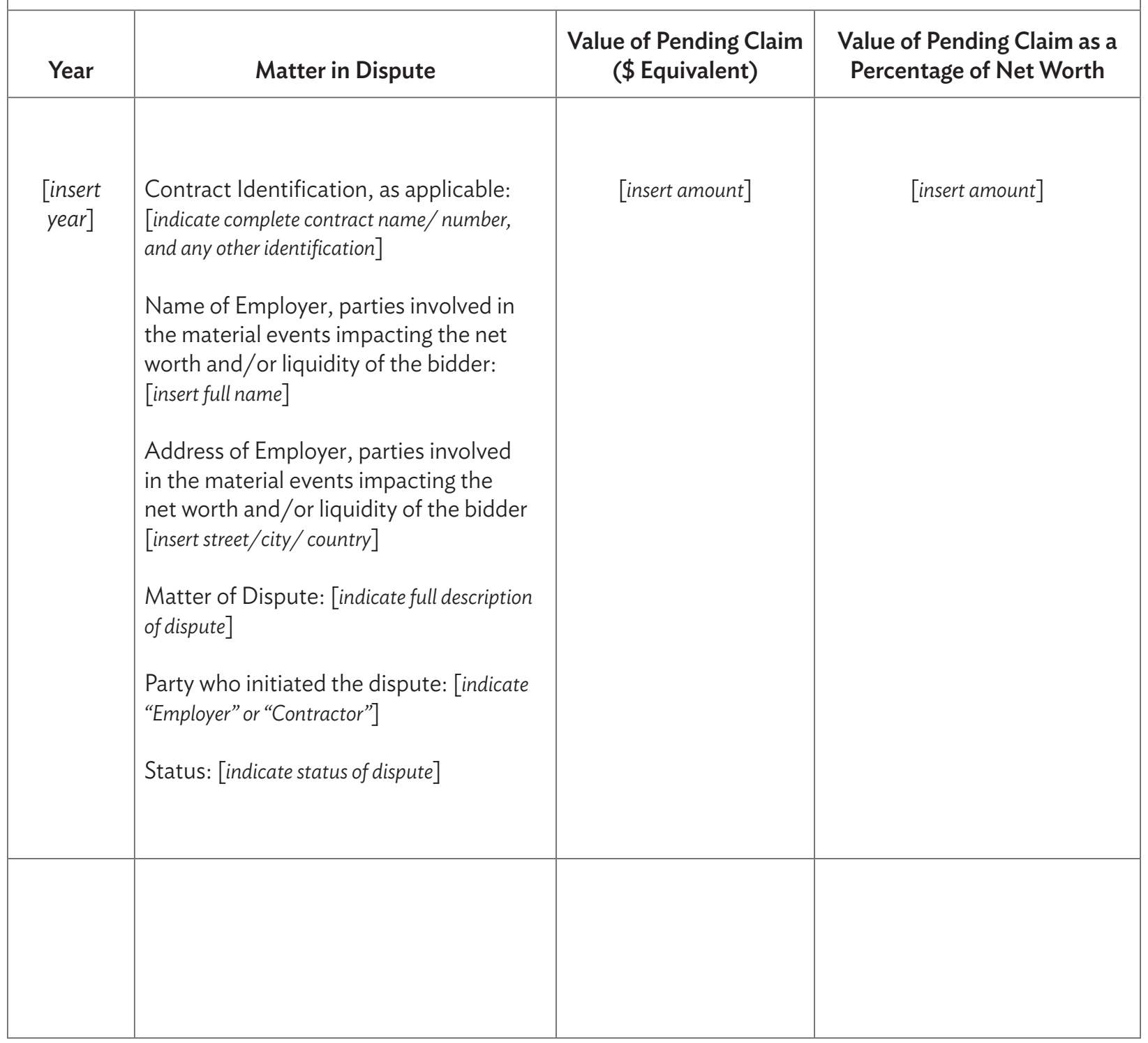

\section{NOTE}

Table 2 of this form shall only be included if Criterion 2.2.3 of Section 3 (Evaluation and Qualification Criteria) is applicable. 


\section{Form CON - 2: EHS Performance Declaration}

Each Bidder must fill out this form in accordance with Criterion 2.2.4 of Section 3 (Evaluation and Qualification Criteria).

In case of a Joint Venture, each Joint Venture Partner must fill out this form separately and provide the Joint Venture Partner's name:

Joint Venture Partner:

In case of a Specialist Subcontractors, each Specialist Subcontractor must fill out this form and provide the Subcontractor's name:

Specialist Subcontractor:

\section{Environmental, Health and Safety Performance Declaration in accordance with Section 3 (Evaluation and Qualification Criteria)}

- No suspension or termination of contract: An employer has not suspended or terminated a contract and/or called the performance security for a contract for reasons related to Environmental or Health and Safety performance since the date specified in Criterion 2.5 of Section 3 (Evaluation and Qualification Criteria).

- Declaration of suspension or termination of contract: The following contract(s) has/have been suspended or terminated and/or Performance Security called by an employer(s) for reasons related to Environmental or Health and Safety performance since the date specified in Criterion 2.5 of Section 3 (Evaluation and Qualification Criteria). Details are described below:

- Declaration of request for replacement of Key Environment, Health and Safety Personnel: The following contract(s) has/have experienced a request by the Employer to replace Environmental, Health and Safety Personnel for reasons related to Environmental or Health and Safety performance since the date specified in Criterion 2.5 of Section 3 (Evaluation and Qualification Criteria). Details are described below:

- Declaration of past fatality resulted from EHS issues on site: The following contract(s) has/have experienced a fatality resulted from EHS issues on site since the date specified in Criterion 2.5 of Section 3 (Evaluation and Qualification Criteria). Details are described below:

\begin{tabular}{|c|c|c|c|}
\hline Year & $\begin{array}{c}\text { Suspended or } \\
\text { terminated } \\
\text { portion of } \\
\text { contract }\end{array}$ & \multicolumn{1}{|c|}{ Contract Identification } & $\begin{array}{c}\text { Total Contract Amount } \\
\text { (current value, currency, } \\
\text { exchange rate and } \\
\text { \$ equivalent) }\end{array}$ \\
\hline [insert year] & $\begin{array}{c}\text { [insert amount and } \\
\text { percentage] }\end{array}$ & $\begin{array}{l}\text { Contract Identification: [indicate complete contract } \\
\text { name/number, and any other identification] }\end{array}$ & [insert amount] \\
& $\begin{array}{l}\text { Name of Employer: [insert full name] } \\
\text { Address of Employer: [insert street/city/country] }\end{array}$ & $\begin{array}{l}\text { Reason(s) for suspension or termination: [indicate } \\
\text { main reason(s) e.g. discharge over environmental limit, workers } \\
\text { did not have required health and safety permits to undertake } \\
\text { high risk work, work carried out was not adhered to approved } \\
\text { construction methodology and quality control plan] }\end{array}$ & \\
\hline
\end{tabular}




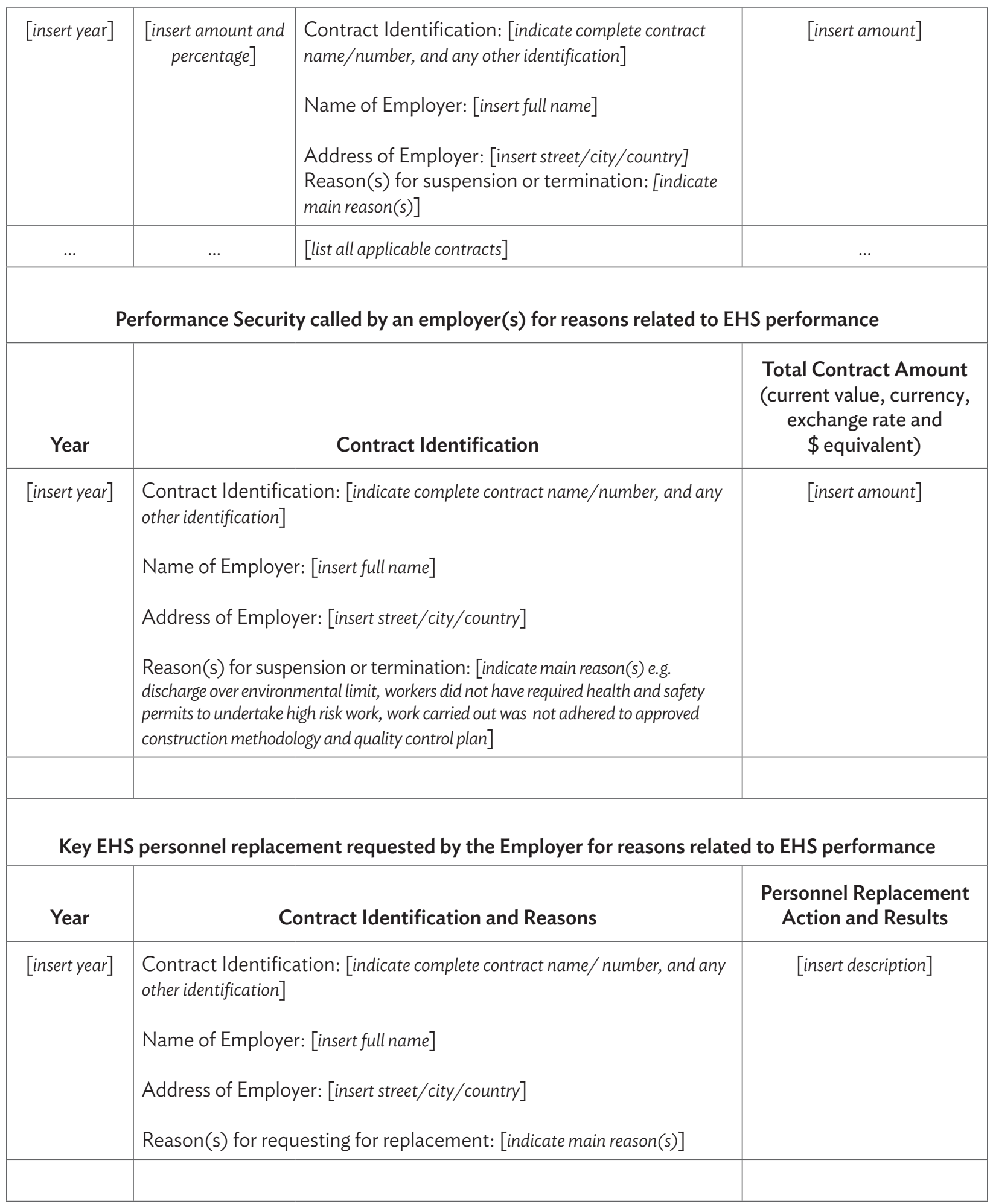


Fatality due to EHS issues on Site

\begin{tabular}{|c|c|c|}
\hline Year & Contract Identification & $\begin{array}{l}\text { Follow-on Actions Taken } \\
\text { by the Contractor }\end{array}$ \\
\hline [insert year] & $\begin{array}{l}\text { Contract Identification: [indicate complete contract name/number, and any } \\
\text { other identification] } \\
\text { Name of Employer: [insert full name] } \\
\text { Address of Employer: [insert street/city/country] } \\
\text { Description of fatality event: } \\
\text { Causation: }\end{array}$ & [insert description] \\
\hline
\end{tabular}




\section{Form FIN - 1: Historical Financial Performance}

Each Bidder must fill out this form.

In case of a Joint Venture, each Joint Venture Partner must fill out this form separately and provide the Joint Venture Partner's name:

Joint Venture Partner:

Financial Data for Previous 3 Years ${ }^{\mathrm{a}}$ [\$ Equivalent]

\begin{tabular}{|l|l|l}
\hline Year 1: & Year 2: & Year 3: \\
\hline
\end{tabular}

Information from Balance Sheet

\begin{tabular}{|l|l|l|l|}
\hline Total Assets (TA) & & & \\
\hline Total Liabilities (TL) & & & \\
\hline Net Worth = TA - TL & & & \\
\hline Current Assets (CA) & & & \\
\hline Current Liabilities (CL) & & & \\
\hline Working Capital = CA - CL & & $\begin{array}{l}\text { To be obtained for most recent year and carried } \\
\text { forward to FIN - 3 Line 1; in case of Joint } \\
\text { Ventures, to the corresponding Joint Venture } \\
\text { Partner's FIN - 3. }\end{array}$ \\
\hline Most Recent Working Capital & & \\
\hline
\end{tabular}

Information from Income Statement

\begin{tabular}{|l|l|l|l|}
\hline Total Revenues & & & \\
\hline Profits Before Taxes & & & \\
\hline Profits After Taxes & & & \\
\hline
\end{tabular}

$\square$ Attached are copies of financial statements (balance sheets including all related notes, and income statements) for the last 3 years, ${ }^{b}$ as indicated above, complying with the following conditions:

1. Unless otherwise required by Section 3 of the Bidding Documents, all such documents reflect the standalone financial situation of the legal entity or entities comprising the Bidder and not the Bidder's parent companies, subsidiaries, or affiliates. ${ }^{c}$

2. Historical financial statements must be audited by a certified accountant.

3. Historical financial statements must be complete, including all notes to the standalone financial statements.

4. Historical financial statements must correspond to accounting periods already completed and audited (no statements for partial periods shall be requested or accepted).

a If the time period indicated under Criterion 2.3.1 of Section 3 (Evaluation and Qualification Criteria) is either 4 or 5 years, then the table columns above should be expanded accordingly.

b The time period stated here should be the same as the time period indicated under Criterion 2.3.1 of Section 3 (Evaluation and Qualification Criteria).

c When financial qualifications of Bidder's parent companies, subsidiaries, or affiliates are permitted in accordance with ITB 38.2 of Section 2, replace the text of condition 1 with "As required by Section 3 of the Bidding Documents, all such documents reflect the standalone financial situation of the legal entity or entities comprising the Bidder, as well as standalone financial situation of such Bidder's parent companies, subsidiaries, or affiliates which are proposed by the Bidder for Criteria 2.3 Financial Situation in Section 3 for consideration of the Employer in determining its qualifications." 


\section{Form FIN - 2: Average Annual Turnover}

Each Bidder must fill out this form.

The information supplied should be the Annual Turnover of the Bidder or each partner of a Joint Venture for the total certified payments received from the clients for contracts in progress or completed, converted to US dollars at the rate of exchange at the end of the period reported.

In case of a Joint Venture, each Joint Venture Partner must fill out this form separately and provide the Joint Venture Partner's name:

Joint Venture Partner:

\begin{tabular}{|l|c|c|c|}
\hline \multicolumn{3}{|c|}{ Annual Turnover Data for the Last.... Years } \\
\hline \multirow{3}{*}{ Year } & $\begin{array}{c}\text { Amount } \\
\text { Currency }\end{array}$ & $\begin{array}{c}\text { Exchange } \\
\text { Rate }\end{array}$ & \$ Equivalent \\
\hline & & & \\
\hline & & & \\
\hline & & & \\
\hline
\end{tabular}

a The Employer should insert the period described in Criterion 2.3.2 of Section 3 (Evaluation and Qualification Criteria).

b To determine the average annual turnover, the employer shall divide the sum of each year's annual turnover by the number of years for which such information was requested. 


\section{Form FIN - 3: Availability of Financial Resources}

Bidders must demonstrate sufficient financial resources, usually comprising of Working Capital supplemented by credit line statements or overdraft facilities and others to meet the Bidder's financial requirements for

(a) its current contract commitments, and

(b) the subject contract.

In case of a Joint Venture, each Joint Venture Partner must fill out this form separately and provide the Joint Venture Partner's name:

Joint Venture Partner:

\begin{tabular}{|c|l|c|}
\multicolumn{2}{|c|}{ Financial Resources } \\
\hline No. & \multicolumn{1}{|c|}{ Source of financing } & Amount (\$ equivalent) \\
\hline 1 & Working Capital (to be taken from FIN - 1) & \\
\hline 2 & Credit Line ${ }^{a}$ & \\
\hline 3 & Other Financial Resources & \\
\cline { 2 - 3 } Total Available Financial Resources & \\
\cline { 2 - 3 } &
\end{tabular}

a To be substantiated by a letter from the bank issuing the line of credit.

\section{NOTE}

Further details on credit line requirements may be discussed and agreed upon during preparation of bidding document stage. 


\section{Form FIN - 4: Financial Requirements for Current Contract Commitments}

Bidders (or each Joint Venture partner) should provide information on their current commitments on all contracts that have been awarded, or for which a letter of intent or acceptance has been received, or for contracts approaching completion, but for which an unqualified, full completion certificate has yet to be issued.

In case of a Joint Venture, each Joint Venture Partner must fill out this form separately and provide the Joint Venture Partner's name:

Joint Venture Partner:

\begin{tabular}{|c|c|c|c|c|c|c|}
\hline \multicolumn{7}{|c|}{ Current Contract Commitments } \\
\hline No. & $\begin{array}{l}\text { Name of } \\
\text { Contract }\end{array}$ & $\begin{array}{l}\text { Employer's } \\
\text { Contact } \\
\text { (Address, } \\
\text { Tel, Fax) }\end{array}$ & $\begin{array}{l}\text { Contract } \\
\text { Completion } \\
\text { Date }\end{array}$ & $\begin{array}{l}\text { Outstanding } \\
\text { Contract } \\
\text { Value }(\mathrm{X})^{\mathrm{a}}\end{array}$ & $\begin{array}{l}\text { Remaining } \\
\text { Contract } \\
\text { Period in } \\
\text { Months } \\
(Y)^{\mathbf{b}}\end{array}$ & $\begin{array}{l}\text { Monthly Financial } \\
\text { Resources Requirement } \\
(\mathrm{X} / \mathrm{Y})\end{array}$ \\
\hline \multicolumn{7}{|l|}{1} \\
\hline \multicolumn{7}{|l|}{2} \\
\hline \multicolumn{7}{|l|}{3} \\
\hline 4 & & & & & & \\
\hline & tal Month & inancial Reg & ement for $\mathrm{C}$ & ent Contract & nmitments & $\$ \ldots \ldots \ldots \ldots \ldots$ \\
\hline
\end{tabular}

a Remaining outstanding contract values to be calculated from 28 days prior to the bid submission deadline (\$ equivalent based on the foreign exchange rate as of the same date).

b Remaining contract period to be calculated from 28 days prior to bid submission deadline. 


\section{Form FIN - 5: Self-Assessment Tool for Bidder's Compliance to Financial Resources (Criterion 2.3.3 of Section 3)}

This form requires the same information submitted in Forms FIN - 3 and FIN - 4. All conditions of "Available Financial Resources Net of CCC $\geq$ Requirement for the Subject Contract" must be satisfied to qualify.

\section{Form FIN - 5A: For Single Entities}

\begin{tabular}{|c|c|c|c|c|c|}
\hline $\begin{array}{l}\text { For Single Entities: } \\
\text { (A) }\end{array}$ & $\begin{array}{l}\text { Total Available } \\
\text { Financial } \\
\text { Resources } \\
\text { from FIN - 3 } \\
\text { (B) }\end{array}$ & $\begin{array}{c}\text { Total Monthly Financial } \\
\text { Requirement for Current } \\
\text { Contract Commitments } \\
\text { (CCC) from FIN - } 4 \\
\text { (C) }\end{array}$ & $\begin{array}{l}\text { Available } \\
\text { Financial } \\
\text { Resources } \\
\text { Net of CCC } \\
\text { D = (B - C) }\end{array}$ & $\begin{array}{l}\text { Requirement } \\
\text { for the Subject } \\
\text { Contract } \\
\text { (E) }\end{array}$ & $\begin{array}{l}\text { Results: } \\
\text { Yes or No } \\
\text { [D must be greater } \\
\text { than or equal to } E] \\
\text { (F) }\end{array}$ \\
\hline$\overline{\text { (Name of Bidder) }}$ & & & & $\ldots \ldots \ldots \ldots .^{a}$ & \\
\hline
\end{tabular}

\section{Form FIN - 5B: For Joint Ventures}

\begin{tabular}{|c|c|c|c|c|c|}
\hline $\begin{array}{l}\text { For Joint Ventures: } \\
\text { (A) }\end{array}$ & $\begin{array}{l}\text { Total Available } \\
\text { Financial } \\
\text { Resources } \\
\text { from FIN - } 3 \\
\text { (B) }\end{array}$ & $\begin{array}{l}\text { Total Monthly Financial } \\
\text { Requirement for Current } \\
\text { Contract Commitments } \\
\text { (CCC) from FIN - } 4 \\
\text { (C) }\end{array}$ & $\begin{array}{l}\text { Available } \\
\text { Financial } \\
\text { Resources } \\
\text { Net of CCC } \\
D=(B-C)\end{array}$ & $\begin{array}{l}\text { Requirement } \\
\text { for the Subject } \\
\text { Contract } \\
\text { (E) }\end{array}$ & $\begin{array}{l}\text { Results: } \\
\text { Yes or No } \\
{[D \text { must be greater }} \\
\text { than or equal to } E] \\
\text { (F) }\end{array}$ \\
\hline \multicolumn{6}{|l|}{ One Partner: } \\
\hline \multicolumn{6}{|l|}{ (Name of Partner) } \\
\hline \multicolumn{6}{|l|}{ Each Partner: } \\
\hline \multicolumn{6}{|l|}{$(\overline{\text { Name of Partner } 1)}$} \\
\hline \multicolumn{6}{|l|}{ (Name of Partner 2 ) } \\
\hline \multicolumn{6}{|l|}{$(\overline{\text { Name of Partner } 3)}$} \\
\hline $\begin{array}{l}\text { All partners } \\
\text { combined }\end{array}$ & $\begin{array}{l}\sum \mathrm{D}=\text { Sum of av } \\
\text { net of current } \mathrm{Cc} \\
\text { for all partners }\end{array}$ & $\begin{array}{l}\text { ailable financial resources } \\
\text { ontract commitments }\end{array}$ & $\sum D=$ & $\theta^{a}$ & \\
\hline
\end{tabular}

a The Employer should insert here the total requirement for the Subject Contract (for both, single entity and all partners combined) as defined in Criterion 2.3.3 of Section 3.

b The Employer should insert here the required share for one partner as defined in Criterion 2.3.3 of Section 3.

c The Employer should insert here the required share for each partner as defined in Criterion 2.3.3 of Section 3.

\section{NOTE}

Form FIN - 5 is made available for use by the Bidder as a self-assessment tool, and by the Employer as an evaluation work sheet, to determine compliance with the financial resources requirement as stated in 2.3.3. Failure to submit Form FIN-5 by the Bidder shall not lead to bid rejection. 


\section{Form EXP - 1: Contracts of Similar Size and Nature}

Fill out one (1) form per contract. Each contract shall be supported by documents such as Signed Contract Agreement, Taking-Over Certificate, Contract Completion Certificate, or Performance Certificate.

The exchange rate to be used to calculate the value of the contract for conversion to a specific currency shall be the selling rate of the Borrower's Central bank on the date of the contract.

\section{Contract of Similar Size and Nature}

\section{Contract No..... of .... Contract Identification}

\begin{tabular}{|l|l|l|}
\hline \multicolumn{2}{|l|}{ Award Date } & \multicolumn{2}{|l|}{ Completion Date } \\
\hline Role in Contract & $\square$ Contractor & $\begin{array}{l}\text { Management } \\
\text { Contractor }\end{array} \quad$ Subcontractor \\
\hline $\begin{array}{l}\text { Total Contract Amount } \\
\text { If partner in a Joint Venture } \\
\text { or Subcontractor, } \\
\text { specify participation of } \\
\text { total contract amount }\end{array}$ & $\$$ & Amount \\
\hline $\begin{array}{l}\text { Employer's name } \\
\text { Address } \\
\text { Telephone number } \\
\text { Fax number } \\
\text { E-mail }\end{array}$ & Percent of Total & \multicolumn{2}{|l|}{} \\
\hline
\end{tabular}

\section{NOTE}

The Employer should insert here contract size, complexity, methods, technology, or other characteristics as described in Criterion 2.4.1 of Section 3 against which the Bidder demonstrates similarity in the box on the right-hand side. 


\section{Form EXP - 2: Experience in Key Activities}

Fill out one (1) form per contract. Each contract shall be supported by documents such as Signed Contract Agreement, Taking-Over Certificate, or Contract Completion Certificate.

Each Bidder must fill out this form.

If complied by Specialist Subcontractors, each Specialist Subcontractor must fill out this form and provide the Specialist Subcontractor's name:

Specialist Subcontractor:

\section{Contract with Similar Key Activities}

Contract No..... of .... Contract Identification

\begin{tabular}{|l|l|l|}
\hline \multicolumn{2}{|l|}{ Award Date } & \multicolumn{2}{l|}{ Completion Date } \\
\hline Role in Contract & $\square$ Contractor $\quad \begin{array}{l}\text { Management } \\
\text { Contractor }\end{array} \quad$ Subcontractor \\
\hline Total Contract Amount & $\$$ & Amount \\
\hline $\begin{array}{l}\text { If partner in a Joint Venture } \\
\text { or Subcontractor, } \\
\text { specify participation of } \\
\text { total contract amount }\end{array}$ & Percent of Total \\
\hline $\begin{array}{l}\text { Employer's name } \\
\text { Address } \\
\text { Telephone number } \\
\text { Fax number } \\
\text { E-mail }\end{array}$ &
\end{tabular}

Description of the Key Activities in Accordance with Criterion 2.4.2 of Section 3 (Evaluation and Qualification Criteria)

\section{NOTE}

The Employer should insert here the highly specialized construction activities listed under Criterion 2.4.2 of Section 3 against which the Bidder demonstrates similarity in the box on the right-hand side. 


\section{Form EXP - 3: Specific Experience in Managing Environmental, Health and Safety Aspects}

Fill out one form per contract.

Each Bidder must fill out this form.

In case of a Joint Venture, each Joint Venture Partner must fill out this form separately and provide the Joint Venture Partner's name:

Joint Venture Partner:

(1) Key Requirement No. 1 in accordance with Criterion 2.4.3 of Section 3:

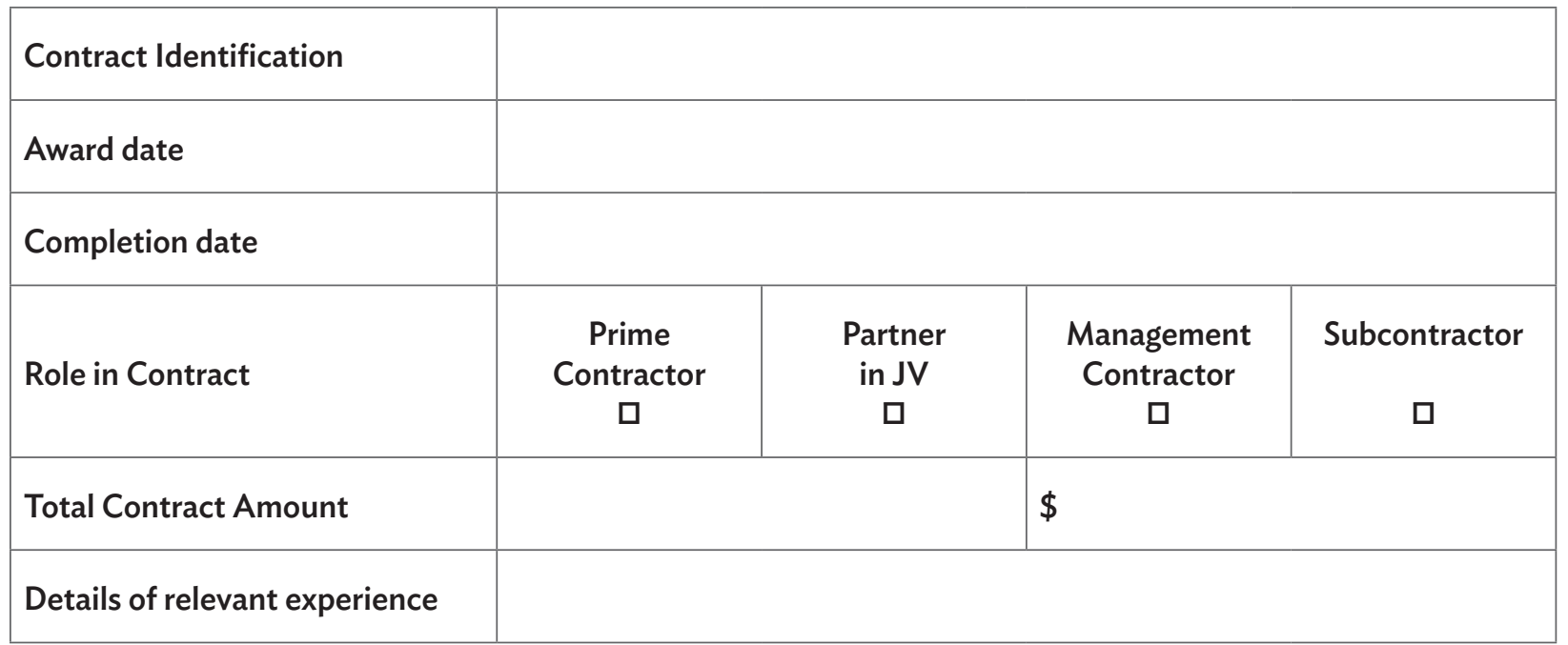

(2) Key Requirement No. 2 in accordance with Criterion 2.4.3 of Section 3:

(3) Key Requirement No. 3 in accordance with Criterion 2.4.3 of Section 3: 


\section{Form EXP - 4: Environmental, Health and Safety Certification}

Please provide the following information:

Availability of the following valid ISO certification or internationally-recognized equivalent (equivalency to be demonstrated by the Bidder), and applicable to the worksite:

[Select the required certifications from below $]^{a}$

- Quality management certificate ISO 9001

- Environmental management certificate ISO 14001

- Health and Safety management certificate ISO 45001

a Depending on the environmental, health, and safety issues of the worksite and the type of competition planned (national or international), the list of required certifications may be restricted to those corresponding to the main issue of the worksite management, or removed altogether. 


\section{Form EXP - 5: Environmental, Health and Safety Documentation}

Please provide the following information:

Availability of in-house policies and procedures acceptable to the Employer for EHS management:

(1) Existence of an Ethics Charter.

(2) Existence of a system for monitoring compliance with EHS commitments for the Bidder's Subcontractors and all its partners.

(3) Existence of official company procedures for the management of the following relevant points:

[Select 3-5 that apply for the worksite from below options- as per Section 2]

-EHS resources and facilities and EHS monitoring system;

- Project Areas management information (base camps, quarries, burrow pits, storage areas);

-Health and Safety on worksites policy and related guidance;

- Local recruitment and EHS trainings of local staff/subcontractors/local partners;

-Community stakeholder engagement practice;

-Traffic management practice;

- Hazardous products management practice;

-Waste management practice;

-Protection of water resources;

-Biodiversity protection practices;

-Site rehabilitation and revegetation practice;

- Local cultural heritage protection practice;

-Erosion and sedimentation practices;

-Control of infectious and communicable diseases (HIV/AIDS, malaria, COVID-19 etc) 


\section{Form EXP - 6: Environmental, Health and Safety Dedicated Personnel}

Please provide CV of the in-house personnel of the main contractor/ Joint Venture partners for the EHS positions specified in Section 6 (Employer's Requirements):

[For example]

-Environmental Specialist

-Health and Safety Specialist 
Form EXP - 7: Subcontractors

Fill out one (1) form per contract.

\section{Contract for the Major Items}

Contract No..... of .... Contract Identification

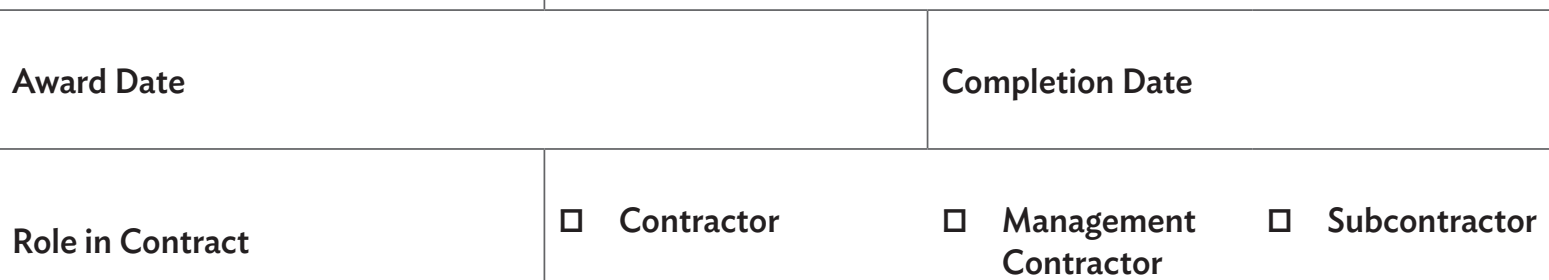

\begin{tabular}{|l|l|l|}
\hline Total Contract Amount & $\$$ \\
\hline $\begin{array}{l}\text { If partner in a Joint Venture } \\
\text { or Subcontractor, } \\
\text { specify participation of } \\
\text { total contract amount }\end{array}$ & Percent of Total & Amount \\
\hline
\end{tabular}

Employer's name

Address

Telephone number

Fax number

E-mail

\section{NOTE}

The Employer should insert here the major items of plant and services listed under Criterion 2.5 of Section 3 against which the Bidder demonstrates similarity in the box on the right-hand side. 


\section{User Guide for Procurement of Plant Design, Supply, and Installation Standard Bidding Document}

This User's Guide is intended to provide guidance to borrowers on how to prepare a bidding document for a single-responsibility contract covering design, supply, and installation of plant, and how to evaluate bids and award contracts, based on the Asian Development Bank's Standard Bidding Document for the Procurement of Plant Design, Supply, and Installation, which is available for both a single-stage bidding procedure and a two-stage bidding procedure. It is applicable to projects governed by the Procurement Regulations for

ADB Borrowers: Goods, Works, Nonconsulting and Consulting Services (2017, as amended from time to time).

\section{About the Asian Development Bank}

ADB is committed to achieving a prosperous, inclusive, resilient, and sustainable Asia and the Pacific, while sustaining its efforts to eradicate extreme poverty. Established in 1966, it is owned by 68 members -49 from the region. Its main instruments for helping its developing member countries are policy dialogue, loans, equity investments, guarantees, grants, and technical assistance. 